\section{Pacific Northwest}

National Laboratory

Operated by Battelle for the

U.S. Departrment of Energy

\section{B orehole D ata Package for C alendar Year 2000-2001 RCRA Wells at Single-Shell Tank Waste Management Area S-SX}

D. G. Horton

V. G. Johnson

August 2001

Prepared for the U.S. D epartment of E nergy under Contract DE-AC06-76RL01830 


\section{DISCLAIMER}

This report was prepared as an account of work sponsored by an agency of the United States Government. Reference herein to any specific commercial product, process, or service by trade name, trademark, manufacturer, or otherwise does not necessarily constitute or imply its endorsement, recommendation, or favoring by the United States Government or any agency thereof, or Battelle Memorial Institute.

\section{PACIFIC NORTHWEST NATIONAL LABORATORY operated by \\ BATTELLE for the UNITED STATES DEPARTMENT OF ENERGY under Contract DE-ACO6-76RL01830}




\title{
Borehole Data Package for Calendar Year 2000-2001 RCRA Wells at Single-Shell Tank Waste Management Area S-SX
}

\author{
D. G. Horton \\ V. G. Johnson
}

August 2001

Prepared for

the U.S. Department of Energy

under Contract DE-AC06-76RL01830

Pacific Northwest National Laboratory

Richland, Washington 99352 


\section{Contents}

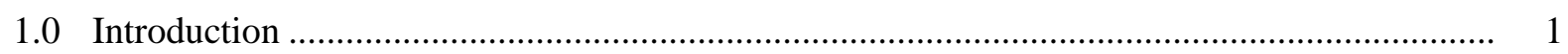

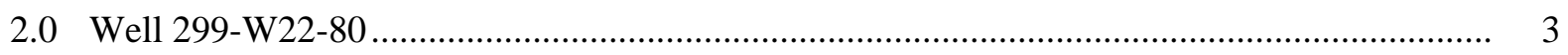

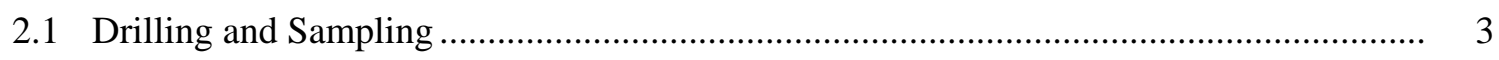

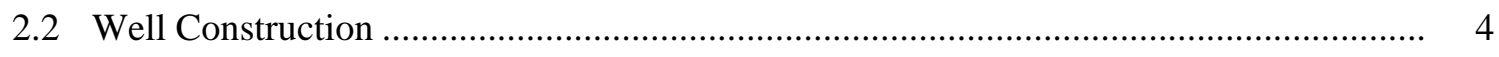

2.3 Well Development and Pump Installation........................................................... 5

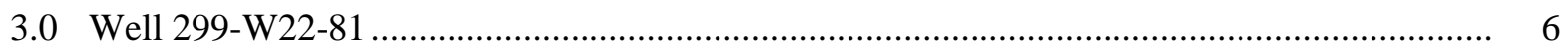

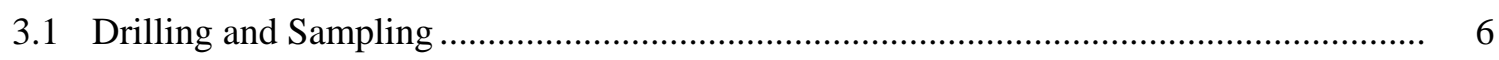

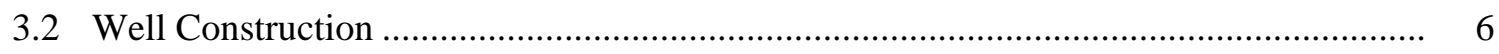

3.3 Well Development and Pump Installation............................................................. 7

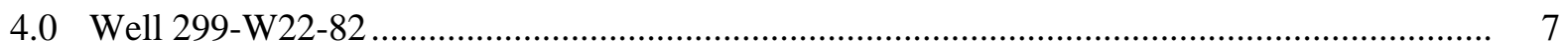

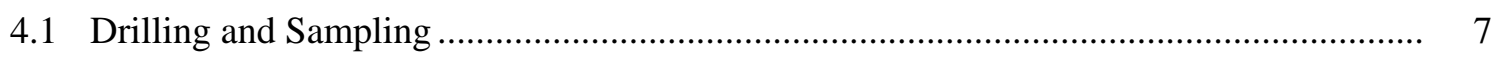

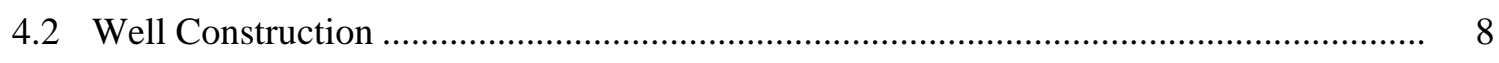

4.3 Well Development and Pump Installation............................................................ 8

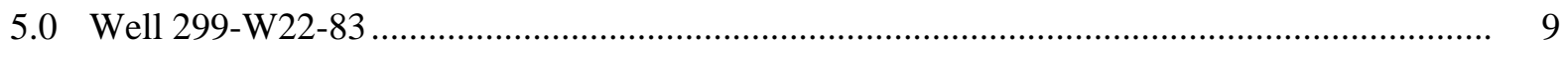

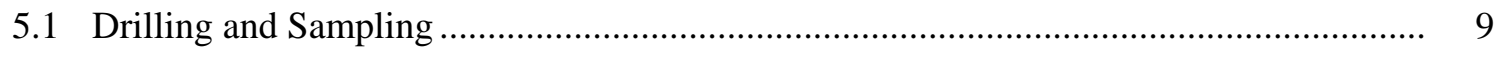

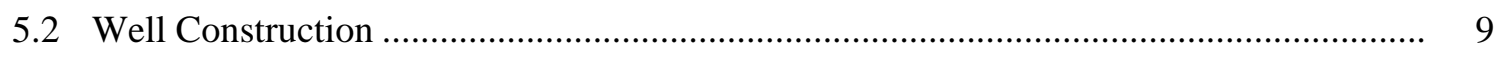

5.3 Well Development and Pump Installation........................................................ 10

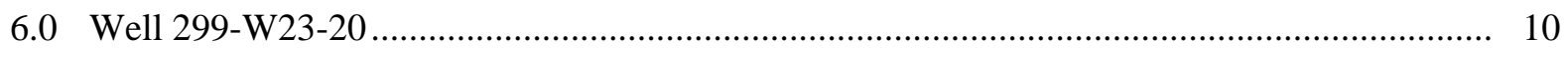

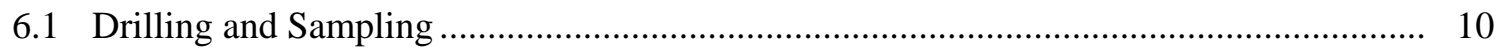

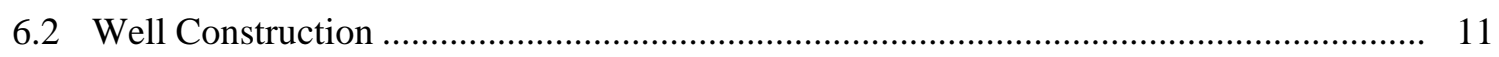

6.3 Well Development and Pump Installation................................................................ 11 


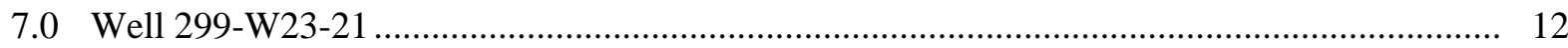

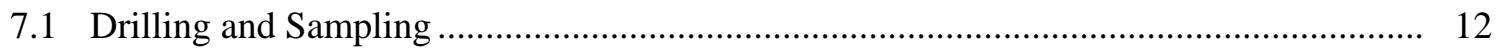



7.3 Well Development and Pump Installation............................................................. 13

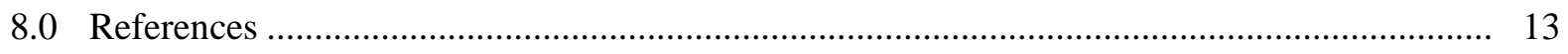

Appendix A - Well Construction and Completion Documentation …..................................... A.1

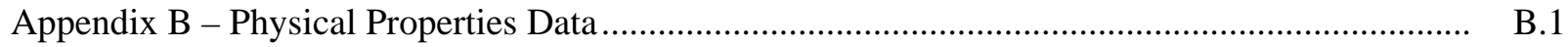

Appendix C - Borehole Geophysical Logs................................................................... C. 1

\section{Figure}

1 Map of Waste Management Area S-SX and Locations of Wells in the Groundwater

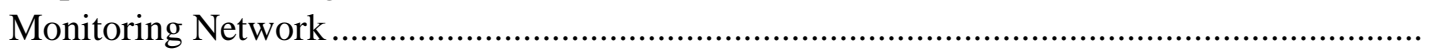

\section{Tables}

$1 \quad$ Well Names and Well Numbers for Wells Drilled in Calendar Year 2000-2001 _................... 1

2 Analytical Results from Groundwater Samples from New Wells at Waste Management

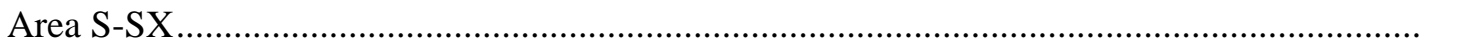

3 Survey Data for New Wells at Waste Management Area S-SX ........................................... 5 


\subsection{Introduction}

Six new Resource Conservation and Recovery Act (RCRA) groundwater monitoring wells were installed at the single-shell tank farm Waste Management Area (WMA) S-SX in July 2000 through March 2001 in partial fulfillment of Tri-Party Agreement (Ecology et al. 1998) milestones M-24-00L and M-24-00M. The wells are 299-W22-80, 299-W22-81, 299-W22-82, 299-W22-83, 299-W23-20, and 299-W23-21. Table 1 correlates the well name with the well number. Well 299-W22-80 is located outside the southeast corner of SX tank farm and is a new downgradient well in the monitoring network. Well 299-W22-81 is a new downgradient well located east of the S and SX tank farm. Well 299-W22-82 is located downgradient of the WMA at approximately $100 \mathrm{~m}$ east of the southeast corner of tank farm SX and well 299-W22-83 is located approximately 100 m southeast of the southeast corner of tank farms SX. Wells 299-W23-20 and 299-W23-21 are located just outside the west S and SX fences respectively and are new upgradient wells in the monitoring network. The locations of all wells in the WMA S-SX monitoring network are shown on Figure 1.

The original assessment monitoring plan for WMA S-SX was issued in 1996 (Caggiano 1996). That plan was updated for the continued assessment at WMA S-SX in 1999 (Johnson and Chou 1999). The updated plan provides justification for the new wells. The new wells were constructed to the specifications and requirements described in Washington Administrative Code (WAC) 173-160 and WAC 173-303, the updated assessment plan for WMA S-SX (Johnson and Chou 1999), and the description of work for well drilling and construction ${ }^{(a)}$.

This document compiles information on the drilling and construction, well development, pump installation, and sediment sampling applicable to the installation of the six new wells. Appendix A contains the Well Summary Sheets (as-built diagrams), the Well Construction Summary Reports, and the geologist's logs; Appendix B contains results of physical properties testing; and Appendix C contains borehole geophysical logs. Additional documentation concerning well construction is on file with Bechtel Hanford, Inc., Richland, Washington.

Table 1. Well Names and Well Numbers for Wells Drilled During Calendar Year 2000-2001

\begin{tabular}{||c|c||}
\hline Well Name & Well Number \\
\hline \hline 299-W22-80 & C3115 \\
\hline 299-W22-81 & C3123 \\
\hline 299-W22-82 & C3124 \\
\hline 299-W22-83 & C3126 \\
\hline 299-W23-20 & C3112 \\
\hline 299-W23-21 & C3113 \\
\hline
\end{tabular}

(a) Letter from J. S. Fruchter, Pacific Northwest National Laboratory, to G. C. Henckel, Bechtel Hanford, Inc., "Description of Work for Drilling CY 2000 RCRA Groundwater Monitoring Wells," dated May 12, 2000. 


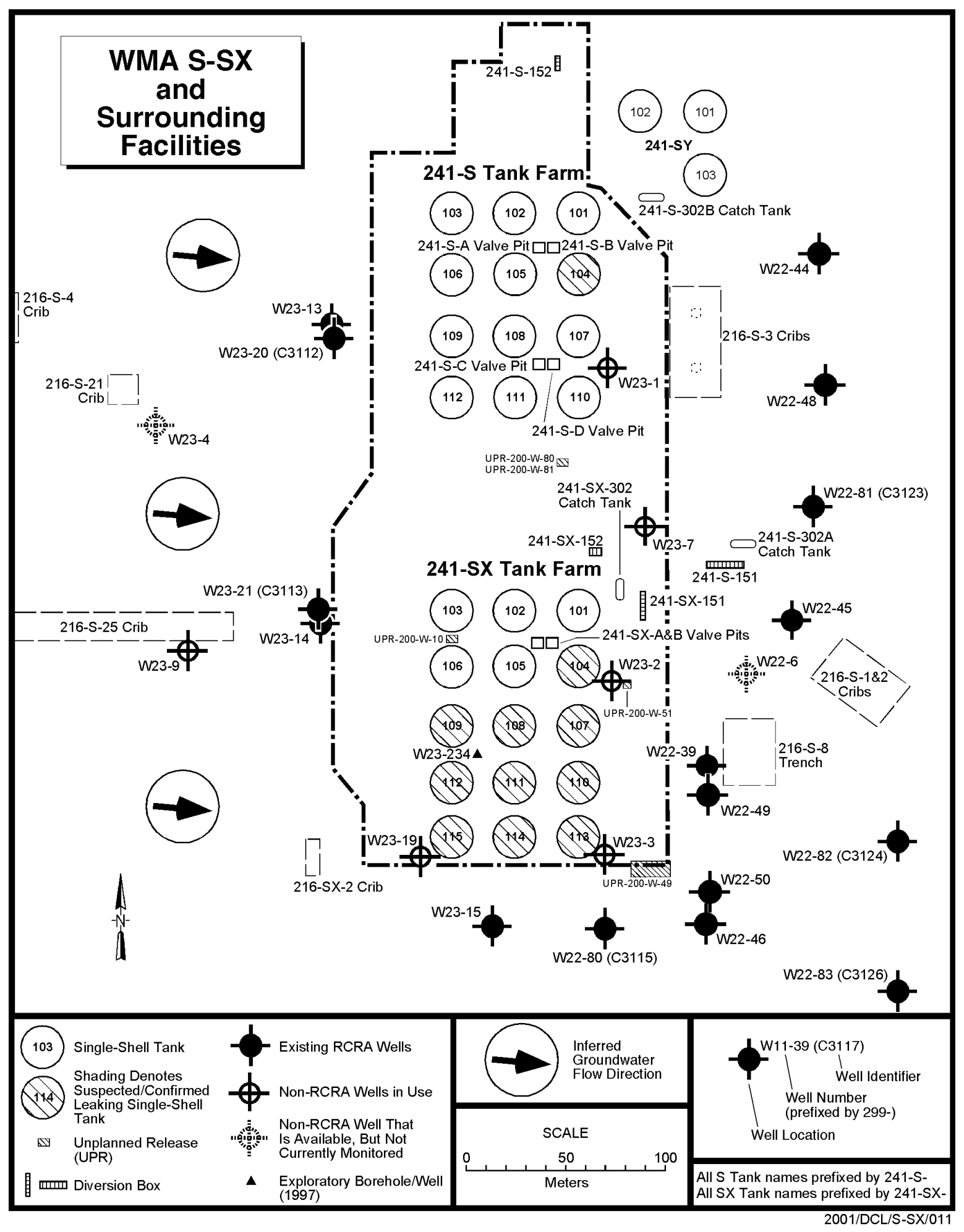

Figure 1. Map of Waste Management Area S-SX and Locations of Wells in the Groundwater Monitoring Network 
English units are used in this report because that is the system of units used by drillers to measure and report depths and well construction details. To convert feet to meters, multiply by 0.3048 ; to convert inches to centimeters multiply by 2.54 .

\subsection{Well 299-W22-80}

Well 299-W22-80 is located outside the southeast corner of the SX tank farm. The well was drilled in September 2000.

\subsection{Drilling and Sampling}

Well 299-W22-80 was drilled with an air rotary drill rig from the surface to a total depth of $251 \mathrm{ft}$ below ground surface (bgs). Temporary 9-in.-outside-diameter, carbon steel casing was used for the entire depth. Approximately 500 gal of water were added to the borehole at $250 \mathrm{ft}$ bgs to suppress flowing sand.

The sediments encountered during drilling were predominantly sand and silty sand of the Hanford formation from the surface to about $128 \mathrm{ft} \mathrm{bgs;}$ Plio-Pliestocene sand with minor silty sandy gravel from about 128 to about $158 \mathrm{ft}$ bgs; and Ringold Formation sandy gravel and gravelly sand from about $158 \mathrm{ft}$ to total depth (251 ft bgs). The geologist's log is included in Appendix A.

Grab samples for geologic description and archive were collected every five feet throughout the borehole. Also, three split spoon samples were taken from 213.3 to $215.8 \mathrm{ft}, 232.0$ to $234.5 \mathrm{ft}$, and from 241.0 to $243.5 \mathrm{ft}$ bgs for analysis of particle size distribution in support of screen slot and filter pack selection. The deepest split spoon sample contained considerable flowing sand. Particle size distribution data are in Appendix B.

Five groundwater samples were collected during drilling. The samples were air lifted slurries of cuttings and water obtained during air rotary drilling. The slurries were filtered using a peristaltic pump and a $0.4-\mu \mathrm{m}$ filter cartridge prior to analysis in the field. The samples were tested for nitrate and specific conductance as a screen for contamination. All analyzed nitrate levels are below the $45 \mathrm{mg} / \mathrm{L}$ maximum contaminant level. The analytical results are shown in Table 2.

The borehole and drill cuttings were monitored regularly for organic vapors and radionuclide contaminants. No contamination was found. 
Table 2. Analytical Results from Groundwater Samples from New Wells at Waste Management Area S-SX

\begin{tabular}{||c|c|c|c|c|}
\hline Well & Depth to Water (ft) & Sample Depth (ft) & Nitrate $(\mathrm{mg} / \mathrm{L})^{(\mathrm{a})}$ & $\begin{array}{c}\text { Specific } \\
\text { Conductance } \\
(\mu \mathrm{S} / \mathrm{cm})\end{array}$ \\
\hline \hline 299-W22-80 & 205 & 213 & 8.7 & 290 \\
\hline & & 227 & 8.4 & 198 \\
\hline & & 232 & 8.1 & 220 \\
\hline & & 242 & 8.1 & 220 \\
\hline & & 259 & 4.2 & 235 \\
\hline 299-W23-21 & 216 & 259 & 1.0 & 213 \\
\hline
\end{tabular}

(a) Nitrate is $\mathrm{mg} / \mathrm{L}$ as $\mathrm{NO}_{3}^{-}$. Analyses were done by the $\mathrm{HACH}$ cadmium reduction method (Method 8039) using a DR/2010 portable spectrophotometer. Reagent blank corrected.

\subsection{Well Construction}

The permanent casing and screen were installed in well 299-W22-80 in September 2000. A 4-in.inner-diameter, stainless steel, wire wrap, 20 slot screen was set from 240.05 to $205.03 \mathrm{ft} \mathrm{bgs}$. The permanent casing is 4-in.-inner-diameter, stainless steel from $205.03 \mathrm{ft}$ bgs to $2.2 \mathrm{ft}$ above ground surface. A 2-ft-long stainless steel sump is below the screen from 242.05 to $240.05 \mathrm{ft}$ depth.

The filter pack is 10 to 20 mesh silica sand from 248.4 to $194.8 \mathrm{ft}$ bgs. The annular seal is bentonite pellets from $194.8 \mathrm{ft}$ to $187.1 \mathrm{ft}$, granular bentonite from $187.1 \mathrm{ft}$ to $10.2 \mathrm{ft}$, and Portland cement grout from $10.2 \mathrm{ft}$ bgs to the surface. A $4 \mathrm{ft}$ by $4 \mathrm{ft}$ by $6 \mathrm{in}$. concrete pad was placed around the well at the surface. A protective casing with locking cap, four protective steel posts, and a brass marker stamped with the well number were set into the concrete. The protective casing extends $2.86 \mathrm{ft}$ above the concrete pad. The Well Summary Sheet (as-built) and Well Construction Summary Report are included in Appendix A.

The vertical and horizontal coordinates of the well were surveyed in March 2001. The horizontal position of the well was determined by Global Positioning System observations referenced to horizontal control stations established by Rogers Surveying, Inc., Richland, Washington, and the U.S. Army Corps of Engineers. The coordinates are Washington Coordinate System, South Zone, NAD83(91) datum. Vertical datum is NAVD 1988 and is based on existing benchmarks established by the U.S. Army Corps of Engineers. Survey data are included in Table 3. 
Table 3. Survey Data for New Wells at Waste Management Area S-SX

\begin{tabular}{|c|c|c|c|c|}
\hline Well Name & $\begin{array}{l}\text { Easting } \\
(\mathrm{m})\end{array}$ & $\begin{array}{l}\text { Northing } \\
\text { (m) }\end{array}$ & $\begin{array}{l}\text { Elevation } \\
(\mathrm{m})\end{array}$ & \\
\hline \multirow{3}{*}{ 299-W22-80 } & $566,842.851$ & $134,125.649$ & & Center of Casing \\
\hline & & & 200.851 & "X" on Rim of Casing \\
\hline & 566.842 .923 & $134,126.030$ & 199.971 & Brass Cap \\
\hline \multirow{3}{*}{ 299-W22-81 } & $567,000.263$ & $134,354.189$ & & Center of Casing \\
\hline & & & 206.644 & Top of Casing \\
\hline & $567,000.235$ & 134354.504 & 205.909 & Brass Cap \\
\hline \multirow{3}{*}{ 299-W22-82 } & $567,004.731$ & $134,167.070$ & & Center of Casing \\
\hline & & & 206.872 & Top of Casing \\
\hline & $567,004.714$ & $134,167.407$ & 206.127 & Brass Cap \\
\hline \multirow{3}{*}{$299 W 22-83$} & $567,009.082$ & $134,092.576$ & & Center of Casing \\
\hline & & & 207.015 & Top of Casing \\
\hline & $567,009.058$ & $134,092.945$ & 206.338 & Brass Cap \\
\hline \multirow{3}{*}{ 299-W23-20 } & $566,717.669$ & $134,446.189$ & & Center of Casing \\
\hline & & & 203.795 & "X" on Rim of Casing \\
\hline & $566,717.817$ & $134,446,568$ & 203.095 & Brass Cap \\
\hline \multirow{3}{*}{ 299-W23-21 } & $566,707.737$ & $134,293.994$ & & Center of Casing \\
\hline & & & 203.352 & "X" on Rim of Casing \\
\hline & $566,707.718$ & $134,294.273$ & 202.579 & Brass Cap \\
\hline
\end{tabular}

\subsection{Well Development and Pump Installation}

Well 299-W22-80 was developed in September 2000. A temporary, $3 \mathrm{hp}$, submersible pump was used to remove approximately 1,945 gal of formation water. First, about 1,015 gal of water were removed from the well at $29 \mathrm{gal} / \mathrm{min}$ with a drawdown of about $2.9 \mathrm{ft}$. The pump intake was at $236.64 \mathrm{ft}$ bgs (31.04 ft below the water table). Second, about $930 \mathrm{gal}$ of water were removed at $30 \mathrm{gal} / \mathrm{min}$ with the pump intake at $215.7 \mathrm{ft}$ bgs resulting in $3 \mathrm{ft}$ drawdown. The final turbidity was $2.75 \mathrm{NTU}$.

A dedicated Hydrostar sampling pump was installed in well 299-W22-80 in September 2000. The sampling pump intake is at $214.46 \mathrm{ft} \mathrm{bgs} \mathrm{(or} \mathrm{about} 8.83 \mathrm{ft}$ below the water table). Static water level was $205.29 \mathrm{ft}$ bgs on September 11, 2000. 


\subsection{Well 299-W22-81}

Well 299-W22-81 is located east of the S-SX tank farm. The well was drilled in January 2001.

\subsection{Drilling and Sampling}

Well 299-W22-81 was drilled with a cable tool drill rig from the surface to a total depth of $269 \mathrm{ft}$ bgs. Temporary 10 5/8-in.-outside-diameter, carbon steel casing was used for the entire depth. The well was advance using drive barrel from the surface to $131 \mathrm{ft}$ depth and by hard tool from $131 \mathrm{ft}$ to total depth.

The sediments encountered during drilling were dominantly sand with lesser amounts of silty sandy gravel and slightly silty sand of the Hanford formation from the surface to about $140 \mathrm{ft}$ bgs; PlioPliestocene silty sand from about 140 to about $163 \mathrm{ft} \mathrm{bgs}$; and Ringold Formation silty sandy gravel and sandy gravel with minor silty sand from about $163 \mathrm{ft}$ to total depth (269 ft bgs). The geologist's log is included in Appendix A.

Grab samples for geologic description and archive were collected every five feet throughout the borehole. Also, three split spoon samples were taken from 238 to $240 \mathrm{ft}, 246.3$ to $248.3 \mathrm{ft}$, and from 260.5 to $262.5 \mathrm{ft}$ bgs for analysis of particle size distribution in support of screen slot and filter pack selection. Particle size distribution data are in Appendix B.

The borehole and drill cuttings were monitored regularly for organic vapors and radionuclide contaminants. No contamination was found. The borehole was geophysically logged with spectral gamma-ray and neutron moisture tools on January 22, 2001. No manmade radionuclides were identified.

\subsection{Well Construction}

The permanent casing and screen were installed in well 299-W22-81 in January 2001. A 4-in.-innerdiameter, stainless steel, wire wrap, 20 slot screen was set from 261.72 to $226.75 \mathrm{ft}$ bgs. The permanent casing is 4-in.-inner-diameter, stainless steel from $226.75 \mathrm{ft}$ bgs to $2.2 \mathrm{ft}$ above ground surface. A 2-ftlong stainless steel sump is below the screen from 263.72 to $261.72 \mathrm{ft}$ depth.

The filter pack is 10 to 20 mesh silica sand from 270.0 to $216.7 \mathrm{ft}$ bgs. The annular seal is bentonite pellets from $216.7 \mathrm{ft}$ to $209.9 \mathrm{ft}$, granular bentonite from $209.9 \mathrm{ft}$ to $11.0 \mathrm{ft}$, and Portland cement grout from $11.0 \mathrm{ft}$ bgs to the surface. A $4 \mathrm{ft}$ by $4 \mathrm{ft}$ by $6 \mathrm{in}$. concrete pad was placed around the well at the surface. A 6-in. stainless steel protective casing with locking cap, four protective steel posts, and a brass marker stamped with the well number were set into the concrete. The protective casing extends $2.37 \mathrm{ft}$ above the concrete pad. The Well Summary Sheet (as-built) and Well Construction Summary Report are included in Appendix A. 
The vertical and horizontal coordinates of the well were surveyed in May 2001. The horizontal position of the well was determined by Global Positioning System observations referenced to horizontal control stations established by Rogers Surveying, Inc., Richland, Washington, and the U.S. Army Corps of Engineers. The coordinates are Washington Coordinate System, South Zone, NAD83(91) datum. Vertical datum is NAVD 1988 and is based on existing benchmarks established by the U.S. Army Corps of Engineers. Survey data are included in Table 3.

\subsection{Well Development and Pump Installation}

Well 299-W22-81 was developed in March 2001. A temporary, $1 \mathrm{hp}$, submersible pump was used to remove approximately $2,325 \mathrm{gal}$ of formation water. First, about 1,805 gal of water were removed from the well at $8.5 \mathrm{gal} / \mathrm{min}$ with a drawdown of about $22 \mathrm{ft}$. The pump intake was at $260.3 \mathrm{ft}$ bgs $(34.04 \mathrm{ft}$ below the water table). Second, about $520 \mathrm{gal}$ of water were removed at $8 \mathrm{gal} / \mathrm{min}$ with the pump intake at $240.33 \mathrm{ft}$ bgs resulting in $12.9 \mathrm{ft}$ of drawdown. The final turbidity was $1.81 \mathrm{NTU}$.

A dedicated, Redi Flo-2 submersible sampling pump was installed in well 299-W22-81 in March 2001. The sampling pump intake is at $237 \mathrm{ft}$ bgs (or about $11.1 \mathrm{ft}$ below the water table). Static water level was $225.9 \mathrm{ft}$ bgs on March 26, 2001.

\subsection{Well 299-W22-82}

Well 299-W22-82 is located east of the southeast corner of SX tank farm. The well was drilled during January and February 2001.

\subsection{Drilling and Sampling}

Well 299-W22-82 was drilled with a cable tool drill rig from the surface to a $270 \mathrm{ft}$ bgs. Temporary $103 / 4$-in.-outside-diameter, carbon steel casing was placed from the surface to $270 \mathrm{ft}$ during drilling. The borehole was advanced by drive barrel from the surface to $110 \mathrm{ft}$ bgs and by hard tool from $110 \mathrm{ft}$ to total depth (270 ft). Two gal of water were added at 110 to $112 \mathrm{ft}, 10 \mathrm{gal}$ at $152 \mathrm{ft}$ and 10 to $15 \mathrm{gal}$ at $260 \mathrm{ft}$ depths to improve sample returns. About $400 \mathrm{gal}$ of water were added at total depth to prevent sand heave.

Preliminary evaluation shows that the sediments encountered during drilling were Hanford formation sand with lesser amounts of silty sand gravelly sand from the surface to $111 \mathrm{ft}$ depth. Plio-Pleistocene silt was encountered from 111 to $112 \mathrm{ft}$ and silty sand from 112 to $137.5 \mathrm{ft}$ bgs. The sediments between $138 \mathrm{ft}$ and $270 \mathrm{ft}$ were dominantly silty sandy gravel with minor gravelly silty sand and silty sand of the Ringold Formation. The geologist's log is in Appendix A. 
Sediment samples were collected at approximately 5-ft intervals for geologic description and archive throughout the entire borehole. Three split spoon samples were collected from 230 to $232.5 \mathrm{ft}, 243.5$ to $246 \mathrm{ft}$, and 260 to $262.5 \mathrm{ft}$ bgs for analysis of grain size distribution. Data are in Appendix B.

The borehole and drill cuttings were monitored regularly for organic vapors and radionuclide contaminants. No contamination was noted. The borehole was geophysically logged with spectral gamma-ray and neutron moisture tools on February 13, 2001. No manmade radioisotopes were found. The geophysical logs are in Appendix C.

\subsection{Well Construction}

The permanent casing and screen were installed in well 299-W22-82 in February 2001. A 4-in.inner-diameter, stainless steel, continuous wire wrap (20 slot) screen was set from 261.2 to $226.1 \mathrm{ft}$ bgs. The permanent casing is 4-in.-inner-diameter stainless steel from $226.1 \mathrm{ft}$ bgs to $2.0 \mathrm{ft}$ above ground surface. A 2-ft-long sump from 263.2 to $261.2 \mathrm{ft}$ is attached to the bottom of the screen.

The filter pack is 10 to 20 mesh silica sand from 263.1 to $215.7 \mathrm{ft}$ bgs. The annular seal is bentonite pellets from 215.7 to $209.4 \mathrm{ft}$ bgs, granular bentonite from 209.4 to $10 \mathrm{ft}$ bgs, and Portland cement with bentonite powder from $10 \mathrm{ft}$ to the surface. A $4 \mathrm{ft}$ by $4 \mathrm{ft}$ by 6 in. concrete pad was placed around the well at the surface. A 6-in. stainless steel protective casing with locking cap, four protective steel posts, and a brass marker stamped with the well number were set into the concrete. The inner casing extends $1.41 \mathrm{ft}$ above the concrete pad and the protective casing extends $2.43 \mathrm{ft}$ above the concrete pad. The Well Summary Sheet (as-built) and Well Construction Summary Report are included in Appendix A.

The vertical and horizontal coordinates of the well were surveyed in May 2001. The horizontal position of the well was determined by Global Positioning System observations referenced to horizontal control stations established by Rogers Surveying, Inc., Richland, Washington and the U.S. Army Corps of Engineers. The coordinates are Washington Coordinate System, South Zone, NAD83(91) datum. Vertical datum is NAVD 1988 and is based on existing benchmarks established by the U.S. Army Corps of Engineers. Survey data are included in Table 3.

\subsection{Well Development and Pump Installation}

Well 299-W22-82 was developed in March 2001. A temporary, $1 \mathrm{hp}$, submersible pump was used to remove approximately about 2,770 gal of formation water. First, about 2,258 gal of water were removed at 8 to $10 \mathrm{gal} / \mathrm{min}$ with the pump intake at $263.2 \mathrm{ft} \mathrm{bgs}$ resulting in $18.8 \mathrm{ft}$ of drawdown. Second, about $512 \mathrm{gal}$ of water were removed at $8 \mathrm{gal} / \mathrm{min}$ with the pump intake at $243.15 \mathrm{ft} \mathrm{bgs}$; drawdown was $15.5 \mathrm{ft}$. The final turbidity was 4.3 NTU.

A dedicated, Redi Flo-2 submersible sampling pump was installed in well 299-W22-82 in March 2001. The sampling pump intake is at $237.4 \mathrm{ft}$ bgs (or $11.1 \mathrm{ft}$ below the water table). Static water level in the well was $226.27 \mathrm{ft}$ bgs on February 23, 2001. 


\subsection{Well 299-W22-83}

Well 299-W22-83 is located $~ 100 \mathrm{~m}$ southeast of the southeast corner of the SX tank farm. The well was drilled in February and March 2001.

\subsection{Drilling and Sampling}

Well 299-W22-83 was drilled with a cable tool drill rig from the surface to a total depth of $269 \mathrm{ft}$ bgs. Temporary 10 3/4-in.-outside-diameter, carbon steel casing was used for the entire depth. The well was advanced using drive barrel from the surface to $150 \mathrm{ft}$ and by hard tool from $150 \mathrm{ft}$ to total depth. Seven gal of water were added to the borehole at $80 \mathrm{ft}$ and $3 \mathrm{gal}$ at $133 \mathrm{ft}$ to facilitate drilling. One hundred ten gal were added between $150 \mathrm{ft}$ and $268 \mathrm{ft}$ during hard tool drilling. Finally, 100 gal were added at total depth to prevent sand heave.

The sediments encountered during drilling were dominantly sand with lesser amounts of silty sand and gravelly sand of the Hanford formation from the surface to about $134 \mathrm{ft}$ bgs. Plio-Pliestocene silty sand and sandy silt (calcrete) were present from $134 \mathrm{ft}$ to about $144 \mathrm{ft}$ bgs. Sandy gravelly silt, sand, silty sand, and sandy gravelly silt of possible Upper Ringold Formation was encountered between $144 \mathrm{ft}$ and $195 \mathrm{ft}$ and Ringold Formation silty sandy gravel silty sandy gravel of the Lower Ringold Formation occurred between $195 \mathrm{ft}$ and total depth (275 ft bgs). The geologist's log is included in Appendix A.

Grab samples for geologic description and archive were collected every $5 \mathrm{ft}$ throughout the borehole. Also, three split spoon samples were taken from 232 to $234 \mathrm{ft}, 247$ to $249 \mathrm{ft}$, and from 262 to $264 \mathrm{ft}$ bgs for analysis of particle size distribution in support of screen slot and filter pack selection. Particle size distribution data are in Appendix B.

The borehole and drill cuttings were monitored regularly for organic vapors and radionuclide contaminants. No contamination was found. The borehole was geophysically logged with spectral gamma-ray and neutron moisture tools on March 7, 2001. No manmade radionuclides were identified.

\subsection{Well Construction}

The permanent casing and screen were installed in well 299-W22-83 in March 2001. A 4-in.-innerdiameter, stainless steel, wire wrap, 20 slot screen was set from 261.3 to $226.3 \mathrm{ft}$ bgs. The permanent casing is 4-in.-inner-diameter, stainless steel from $226.3 \mathrm{ft}$ bgs to $2.0 \mathrm{ft}$ above ground surface. A 2-ft-long stainless steel sump is below the screen from 263.3 to $261.3 \mathrm{ft}$ depth.

The filter pack is 10 to 20 mesh silica sand from 263.3 to $216.3 \mathrm{ft}$ bgs. The annular seal is bentonite pellets from $216.3 \mathrm{ft}$ to $211.3 \mathrm{ft}$, bentonite crumbles from $211.3 \mathrm{ft}$ to $10.0 \mathrm{ft}$, and Portland cement grout from $10.0 \mathrm{ft}$ bgs to the surface. A $4 \mathrm{ft}$ by $4 \mathrm{ft}$ by 6 in. concrete pad was placed around the well at the surface. A 6-in. stainless steel protective casing with locking cap, four protective steel posts, and a brass marker stamped with the well number were set into the concrete. The protective casing extends $2.23 \mathrm{ft}$ 
above the concrete pad and the inner 4-in. casing extends $1.24 \mathrm{ft}$ above the pad. The Well Summary Sheet (as-built) and Well Construction Summary Report are included in Appendix A.

The vertical and horizontal coordinates of the well were surveyed in May 2001. The horizontal position of the well was determined by Global Positioning System observations referenced to horizontal control stations established by Rogers Surveying, Inc., Richland, Washington and the U.S. Army Corps of Engineers. The coordinates are Washington Coordinate System, South Zone, NAD83(91) datum. Vertical datum is NAVD 1988 and is based on existing benchmarks established by the U.S. Army Corps of Engineers. Survey data are included in Table 3.

\subsection{Well Development and Pump Installation}

Well 299-W22-83 was developed in March 2001. A temporary, $3 \mathrm{hp}$, submersible pump was used to remove approximately 2,250 gal of formation water. First, about 1,520 gal of water were removed from the well at $10 \mathrm{gal} / \mathrm{min}$ with a maximum drawdown of about $29 \mathrm{ft}$ and a final drawdown of $9.8 \mathrm{ft}$. The pump intake was at $260.47 \mathrm{ft}$ bgs ( $32.7 \mathrm{ft}$ below the water table). Second, about 730 gal of water were removed at $10 \mathrm{gal} / \mathrm{min}$ with the pump intake at $250.47 \mathrm{ft} \mathrm{bgs}(22.7 \mathrm{ft}$ below the water table $)$ resulting in $7.2 \mathrm{ft}$ of drawdown. The final turbidity was $3.11 \mathrm{NTU}$.

A dedicated, Redi Flo-2 submersible sampling pump was installed in well 299-W22-83 in March 2001. The sampling pump intake is at $237 \mathrm{ft}$ bgs (or about $9.2 \mathrm{ft}$ below the water table). Static water level was $227.77 \mathrm{ft}$ bgs on March 21, 2001.

\subsection{Well 299-W23-20}

Well 299-W23-20 is located outside the west fence of the S tank farm. The well was drilled during July and August 2000.

\subsection{Drilling and Sampling}

Well 299-W23-20 was drilled with an air rotary drill rig from the surface to a total depth of $260 \mathrm{ft}$ bgs. Temporary 8 5/8-in.-outside-diameter, carbon steel casing was placed from the surface to $260 \mathrm{ft}$ during drilling. An unknown amount of water was added to the borehole at $142 \mathrm{ft}$ and $195 \mathrm{ft}$ bgs to flush the system and clear plugged lines.

Preliminary evaluation shows that the sediments encountered during drilling were Hanford formation silty sandy gravel, sandy gravel, and gravelly sand from the surface to $36 \mathrm{ft}$ depth and sand with minor gravelly sand from 36 to $117 \mathrm{ft}$ depth. Calcareous, slightly silty sand and silty sand of the PlioPleistocene unit were encountered from 117 to $157 \mathrm{ft}$ bgs. There was no recovery between depths of 139 and $148 \mathrm{ft}$ but drilling did not indicate a change in lithology. There also was no recovery between 157 and $169 \mathrm{ft}$. Sediments from $169 \mathrm{ft}$ to total depth ( $260 \mathrm{ft}$ bgs) were mostly sandy gravel with some silty sandy gravel of the Ringold Formation. The geologist's log is in Appendix A. 
Sediment samples were collected at approximately 5-ft intervals for geologic description and archive throughout the entire borehole. Three split spoon samples were collected from 219.5 to $222.0 \mathrm{ft}, 236.0$ to $237.5 \mathrm{ft}$ and 250 to $252.6 \mathrm{ft}$ bgs for analysis of grain size distribution. Data are in Appendix B.

The borehole and drill cuttings were monitored regularly for organic vapors and radionuclide contaminants. On July 28, 2000, drilling was suspended because the field radiation screening results collected the previous day were 700 counts per minute above background. The area was posted as a soil contamination zone although the action level was 5,000 decays per minute and laboratory analysis of radiation screening samples collected the previous day did not show the presence of any contamination. No other contamination was noted.

\subsection{Well Construction}

The permanent casing and screen were installed in well 299-W23-20 in August 2000. A 4-in.-innerdiameter, stainless steel, continuous wire wrap (20 slot) screen was set from 250.5 to $215.5 \mathrm{ft} \mathrm{bgs}$. The permanent casing is 4-in.-inner-diameter stainless steel from $215.5 \mathrm{ft}$ bgs to $2.0 \mathrm{ft}$ above ground surface. A 2-ft-long sump from 252.5 to 250.5 is attached to the bottom of the screen.

The filter pack is 10 to 20 mesh silica sand from 260.5 to $205.0 \mathrm{ft}$ bgs. The annular seal is bentonite pellets from 205 to $200.1 \mathrm{ft}$ bgs, bentonite crumbles from 200.1 to $10 \mathrm{ft} \mathrm{bgs,} \mathrm{and} \mathrm{Portland} \mathrm{cement} \mathrm{grout}$ from $10 \mathrm{ft}$ to the surface. A $4 \mathrm{ft}$ by $4 \mathrm{ft}$ by 6 in. concrete pad was placed around the well at the surface. A protective casing with locking cap, four protective steel posts, and a brass marker stamped with the well number were set into the concrete. The inner casing extends $1.30 \mathrm{ft}$ above the concrete pad and the protective casing extends $2.23 \mathrm{ft}$ above the concrete pad. The Well Summary Sheet (as-built) and Well Construction Summary Report are included in Appendix A.

The vertical and horizontal coordinates of the well were surveyed in March 2001. The horizontal position of the well was determined by Global Positioning System observations referenced to horizontal control stations established by Rogers Surveying, Inc., Richland, Washington, and the U.S. Army Corps of Engineers. The coordinates are Washington Coordinate System, South Zone, NAD83(91) datum. Vertical datum is NAVD 1988 and is based on existing benchmarks established by the U.S. Army Corps of Engineers. Survey data are included in Table 3.

\subsection{Well Development and Pump Installation}

Well 299-W23-20 was developed in August 2000. A temporary, $3 \mathrm{hp}$, submersible pump was used to remove approximately about 2,690 gal of formation water. First, about 1,363 gal of water were removed at $29 \mathrm{gal} / \mathrm{min}$ with the pump intake at $248.8 \mathrm{ft}$ bgs resulting in $2 \mathrm{ft}$ drawdown. Second, about 1,325 gal of

water were removed at $26 \mathrm{gal} / \mathrm{min}$ with the pump intake at $228.8 \mathrm{ft} \mathrm{bgs}$; drawdown was not recorded. The final turbidity was 1.95 NTU.

A dedicated Hydrostar sampling pump was installed in well 299-W23-20 in August 2000. The sampling pump intake is at $220.8 \mathrm{ft}$ bgs (or $5.24 \mathrm{ft}$ below the water table). Static water level in the well was $215.6 \mathrm{ft}$ bgs on August 24, 2000. 


\subsection{Well 299-W23-21}

Well 299-W23-21 is located just outside the west fence of the SX tank farm. The well was drilled during September and October 2000.

\subsection{Drilling and Sampling}

Well 299-W23-21 was drilled with a cable tool drill rig using a drive barrel from the surface to $70 \mathrm{ft}$ bgs, split spoon sampler from 70 to $140 \mathrm{ft}$ bgs, and hard tool from $140 \mathrm{ft}$ to a total depth of $259 \mathrm{ft}$ bgs. Temporary 11 3/4-in.-outside-diameter, carbon steel casing was placed from the surface to $76.4 \mathrm{ft}$ bgs and 8 5/8-in.-outside-diameter casing from the surface to $253.5 \mathrm{ft}$ bgs. About 80 gal of water are reported to have been used between 235 and $250 \mathrm{ft}$, but more water may have been added throughout the hard tooled interval.

Preliminary evaluation shows that the sediments encountered during drilling were predominantly sandy gravel, sand and gravelly sand of the Hanford formation from the surface to about $99 \mathrm{ft}$ bgs. Calcareous silty sand, slightly silty sand, and sandy silt of the Plio-Pliestocene unit occur from 99 to $147 \mathrm{ft}$ bgs. Undifferentiated Plio-Pleistocene and/or Upper Ringold Formation sandy silt, sand, and silty gravelly sand exist from $147 \mathrm{ft}$ to about $168 \mathrm{ft}$ bgs. Ringold Formation sandy gravel and silty sandy gravel occur from $168 \mathrm{ft}$ to total depth. The geologist's log is in Appendix A.

The borehole was continuously sampled by split spoon from $70 \mathrm{ft}$ to $140 \mathrm{ft}$ bgs for detailed characterization. Also, three split spoon samples were collected from 217 to $219.5 \mathrm{ft}, 232$ to $234.5 \mathrm{ft}$ and from 247.5 to $250 \mathrm{ft}$ bgs for determination of particle size distribution. The particle size data are in Appendix B; the results of detailed characterization will be presented elsewhere. Grab samples of sediment were collected at approximately 5 -ft intervals throughout the borehole for geologic description and archive.

One groundwater sample was collected at $259 \mathrm{ft}$ bgs with a bailer during drilling. The slurry was filtered using a peristaltic pump and a $0.4-\mu \mathrm{m}$ filter cartridge prior to analysis in the field. The sample was tested for nitrate and specific conductance as a screen for contamination. The analyzed nitrate level is below the $45 \mathrm{mg} / \mathrm{L}$ maximum contaminant level. The analytical result is shown in Table 2.

The borehole and drill cuttings were monitored regularly for organic vapors and radionuclide contaminants. Values up to $860 \mathrm{ppm} \mathrm{CO}$ and $26 \%$ lower explosive limit were detected at about $248 \mathrm{ft}$ bgs. Work was temporarily stopped. No other high meter readings and no contamination were noted in the borehole.

The well was geophysically logged with high resolution, spectral gamma-ray and neutron-neutron moisture instrumentation in October 2000. No manmade radionuclides were detected. The geophysical logs are in Appendix C. 


\subsection{Well Construction}

The permanent casing and screen were installed in well 299-W23-21 in November 2000. A 4-in.inner-diameter, stainless steel, continuous wire wrap, 20 slot screen was set from 249.69 to $212.58 \mathrm{ft}$ bgs. The permanent casing is 4-in.-inner-diameter stainless steel from $212.58 \mathrm{bgs}$ to $2.1 \mathrm{ft}$ above ground surface. A 2-ft-long stainless steel sump was placed below the screen from 251.87 to $249.69 \mathrm{ft}$ bgs.

The filter pack is 10 to 20 mesh silica sand from 257.5 to $202.0 \mathrm{ft}$ bgs. The annular seal is bentonite pellets from 202.0 to $193.7 \mathrm{ft}$ bgs, granular bentonite from 193.7 to $10.1 \mathrm{ft} \mathrm{bgs}$, and Portland cement grout from $10.1 \mathrm{ft}$ depth to the surface. A $4 \mathrm{ft}$ by $4 \mathrm{ft}$ by 6 in. concrete pad was placed around the well at the surface. A protective casing with locking cap, four protective steel posts, and a brass marker stamped with the well number were set into the concrete. The permanent casing extends $2.1 \mathrm{ft}$ and the protective casing extends $3.1 \mathrm{ft}$ above the concrete pad. The Well Summary Sheet (as-built) and Well Construction Summary Report are included in Appendix A.

The vertical and horizontal coordinates of the well were surveyed in March 2001. The horizontal position of the well was determined by Global Positioning System observations referenced to horizontal control stations established by Rogers Surveying, Inc., Richland, Washington, and the U.S. Army Corps of Engineers. The coordinates are Washington Coordinate System, South Zone, NAD83(91) datum. Vertical datum is NAVD 1988 and is based on existing benchmarks established by the U.S. Army Corps of Engineers. Survey data are included in Table 3.

\subsection{Well Development and Pump Installation}

Well 299-W23-21 was developed in November 2000. A temporary, submersible pump was used to remove approximately $1,500 \mathrm{gal}$ of formation water from the well. Initially, $25 \mathrm{ft}$ of drawdown occurred using a pump rate of $6 \mathrm{gal} / \mathrm{min}$. The flow rate was adjusted to $4.5 \mathrm{gpm}$ resulting in $15 \mathrm{ft}$ of drawdown and later to $5.0 \mathrm{gal} / \mathrm{min}$ resulting in $17 \mathrm{ft}$ of drawdown. The final turbidity was $4.89 \mathrm{NTU}$.

A dedicated, Redi Flo-2 submersible sampling pump was installed in well 299-W23-21 in December 2000. The sampling pump intake is at $223 \mathrm{ft}$ bgs (or about $10 \mathrm{ft}$ below the water table). Static water level in the well was $212.7 \mathrm{ft}$ bgs on December 27, 2000.

\subsection{References}

Caggiano, J. A. 1996. Assessment Groundwater Monitoring Plan for Single-Shell Tank Waste Management Area S-SX. WHC-SD-EN-AP-191, Westinghouse Hanford Company, Richland, Washington. 
Ecology - Washington State Department of Ecology, U.S. Environmental Protection Agency, and U.S. Department of Energy. 1998. Hanford Federal Facility Agreement and Consent Order. Document No. 89-10, Rev. 5 (The Tri-Party Agreement), Olympia, Washington.

Johnson, V. G., and C. J. Chou. 1999. RCRA Assessment Plan for Single-Shell Waste Management Area $S$-SX at the Hanford Site. PNNL-12114, Pacific Northwest National Laboratory, Richland, Washington.

RCRA - Resource Conservation and Recovery Act. 1976. Public Law 94-580, as amended, 90 Stat. 2795, 42 USC 6901 et seq.

WAC 173-160, Washington Administrative Code. Minimum Standards for Construction and Maintenance of Wells. Olympia, Washington.

WAC 173-303, Washington Administrative Code. Dangerous Waste Regulations. Olympia, Washington. 
Appendix A

Well Construction and Completion Documentation 


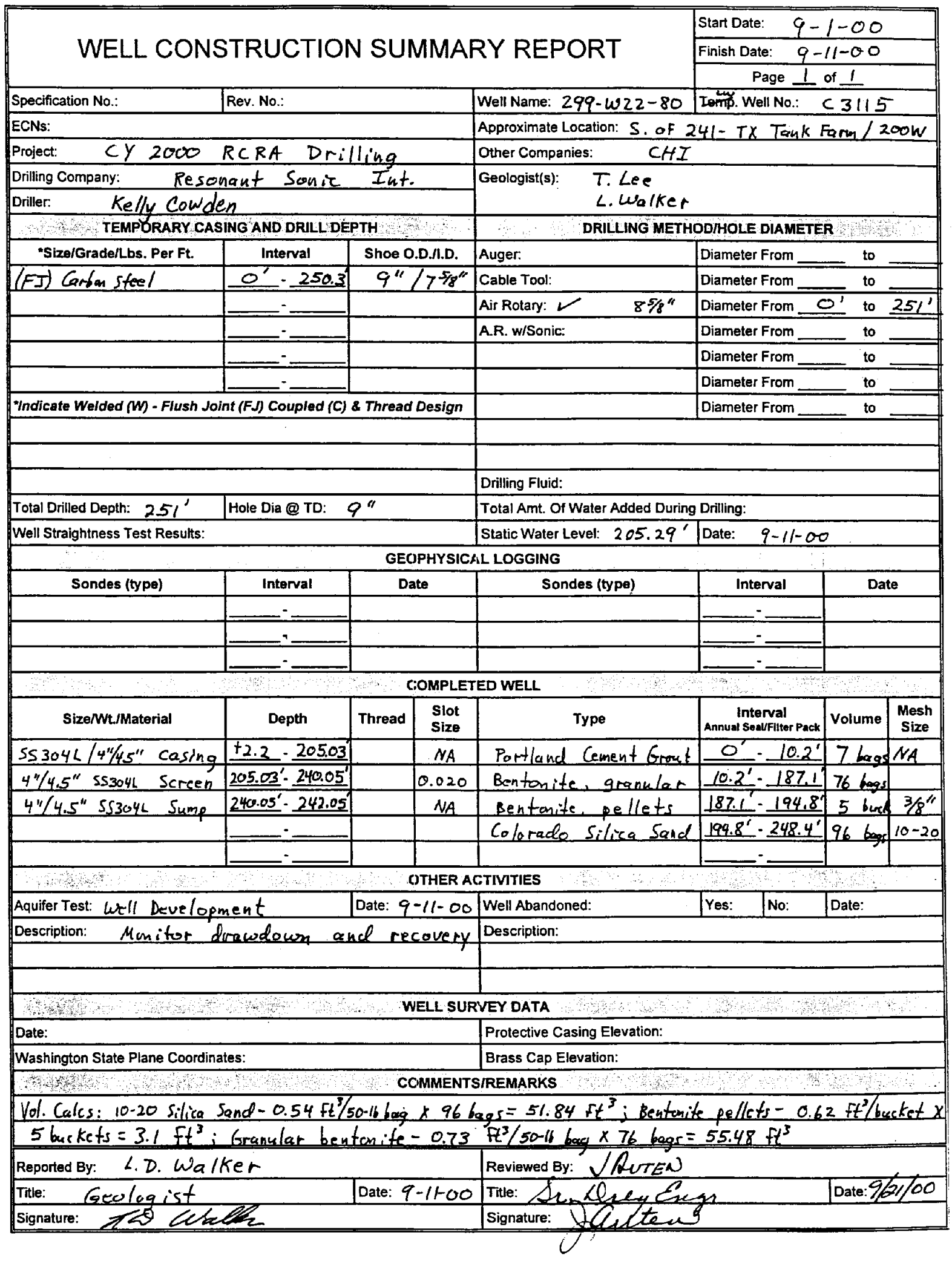

BHI-EE-181 (12/97) 


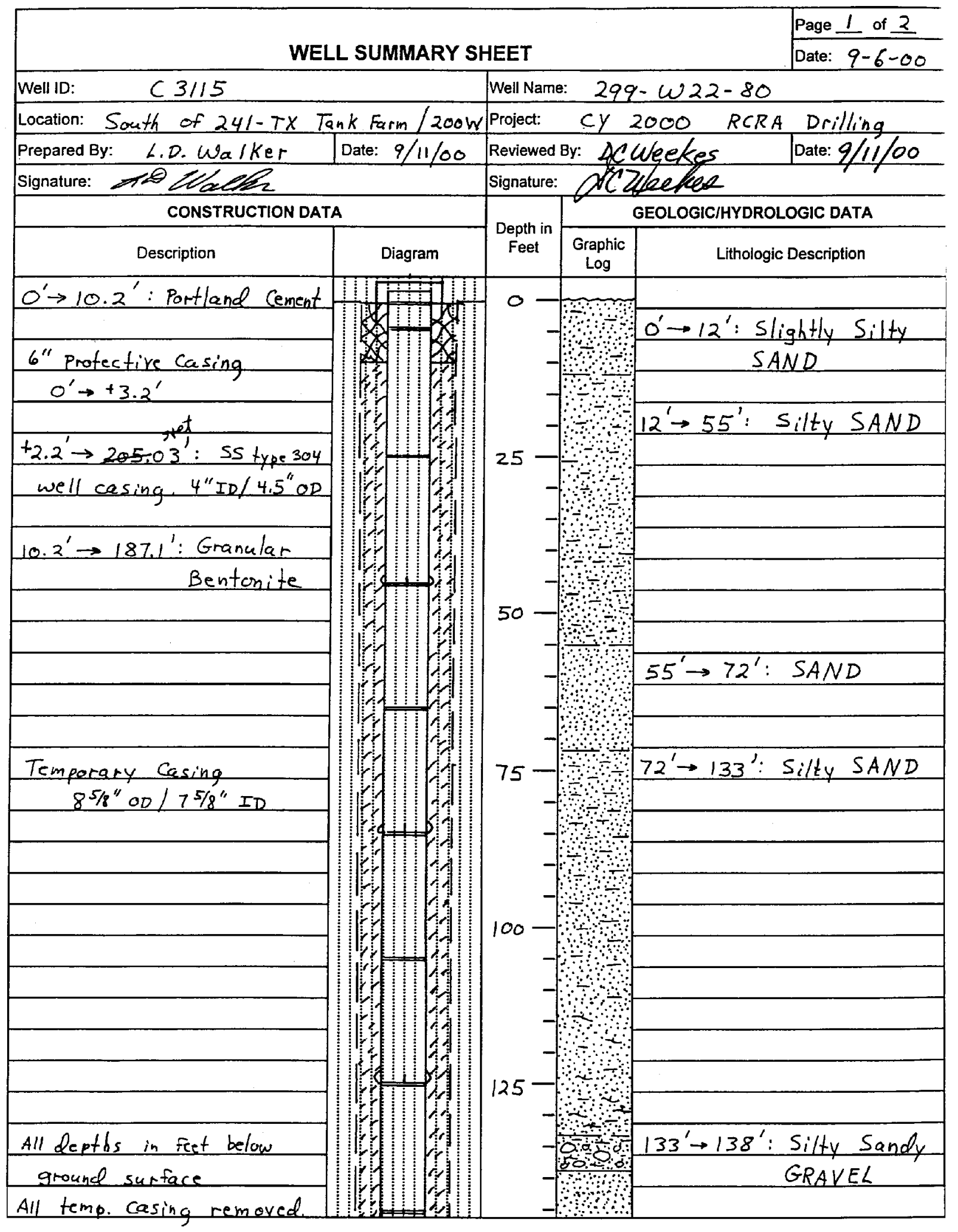

BHI-EE-189 (12/97) 


\begin{tabular}{|c|c|c|c|c|}
\hline \multirow{2}{*}{\multicolumn{5}{|c|}{ Page 2 of $2 \underline{2}$}} \\
\hline \multicolumn{4}{|c|}{ WELL SUMMARY SHEET } & \\
\hline$c 3115$ & & \multicolumn{3}{|c|}{ Well Name: $\quad 299-\omega_{22}-80$} \\
\hline Location: South of 241-TX T & Tank Farm/200w & Project: & $c y$ & $2000 R C R A$ Drilling \\
\hline Prepared By: L,D. Wa/ker & Date: $9 / 11 / 00$ & \multicolumn{3}{|c|}{ Reviewed By: DCWleckes Date: $q / / 1 / 00$} \\
\hline Signature: $T 0$ & & \multicolumn{3}{|c|}{ signature: AC Utee heot } \\
\hline \multicolumn{2}{|c|}{ CONSTRUCTION DATA } & \multirow{2}{*}{$\begin{array}{l}\text { Depth in } \\
\text { Feet }\end{array}$} & \multicolumn{2}{|r|}{ GEOLOGIC/HYDROLOGIC DATA } \\
\hline Description & Diagram & & $\begin{array}{c}\text { Graphic } \\
\text { Log } \\
\end{array}$ & Lithologic Description \\
\hline & \multirow{23}{*}{ 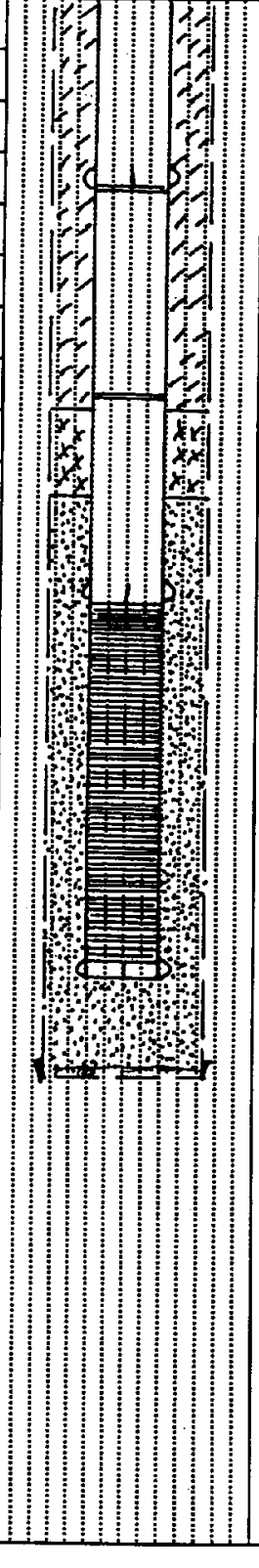 } & \multirow{23}{*}{\multicolumn{2}{|c|}{ 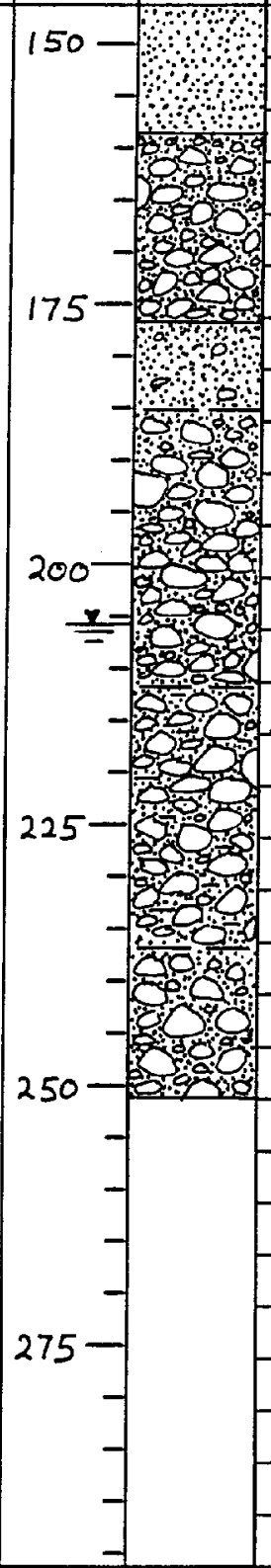 }} & 2010 \\
\hline $187.1^{\prime} \rightarrow 194.8^{\prime}:$ & & & & \\
\hline $38^{\prime \prime}$ Bentonite Pellets & & & & $158^{\prime} \rightarrow 177^{\prime}:$ Sandy GRAVEL \\
\hline $194.8^{\prime} \rightarrow 248.4^{\prime}:$ & & & & \multirow{4}{*}{$\begin{array}{l}177^{\prime} \rightarrow 185^{\prime}: \text { Gravelly SAND } \\
185^{\prime} \rightarrow 212^{\prime}: \text { Sandy GRAVEL }\end{array}$} \\
\hline Silica Sand, $10-20$ mesh & & & & \\
\hline & & & & \\
\hline 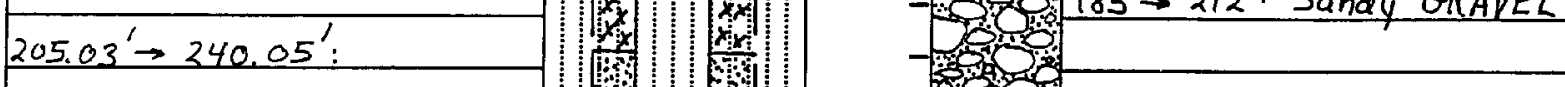 & & & & \\
\hline \multicolumn{2}{|c|}{$19: 1,200-1$} & & & \\
\hline \multicolumn{2}{|l|}{0.020 -in slot cont wire - } & & & \\
\hline \multicolumn{2}{|c|}{ 161 } & & & \\
\hline & & & & \multirow{2}{*}{$\begin{array}{l}212^{\prime} \rightarrow 237^{\prime}: \text { Silty Sandy } \\
\text { GRAVEL }\end{array}$} \\
\hline \multirow{2}{*}{ Wn } & & & & \\
\hline & & & & \\
\hline & & & & $237^{\prime} \rightarrow 251^{\prime}:$ Sandy GRAYEL \\
\hline $248.4^{\prime} \rightarrow 251.0^{\prime}:$ S/uff & & & & \\
\hline \multirow{2}{*}{\multicolumn{2}{|c|}{$\begin{array}{l}\text { Total SS } 4^{\prime \prime} / 4^{\prime} / 2^{\prime \prime} \text { material } \\
\text { is } 244.25^{\prime}\left(+2.2-242.05^{\prime}\right)\end{array}$}} & & & \\
\hline & & & & \\
\hline \multirow[t]{2}{*}{\begin{tabular}{|c|} 
\\
\end{tabular}} & & & & $W . L=205.29^{\prime} \mathrm{bgs}$ \\
\hline & & & & $(9-11-\infty)$ \\
\hline \multirow{2}{*}{\multicolumn{2}{|c|}{ All depths in Feet be low }} & & & \\
\hline & & & & \\
\hline \multirow{2}{*}{$\begin{array}{l}\text { ground surface } \\
\text { All temp. casing remourd } \\
\text { From the around }\end{array}$} & & & & \\
\hline & & & & \\
\hline
\end{tabular}

BHI-EE-189 (12/97) 


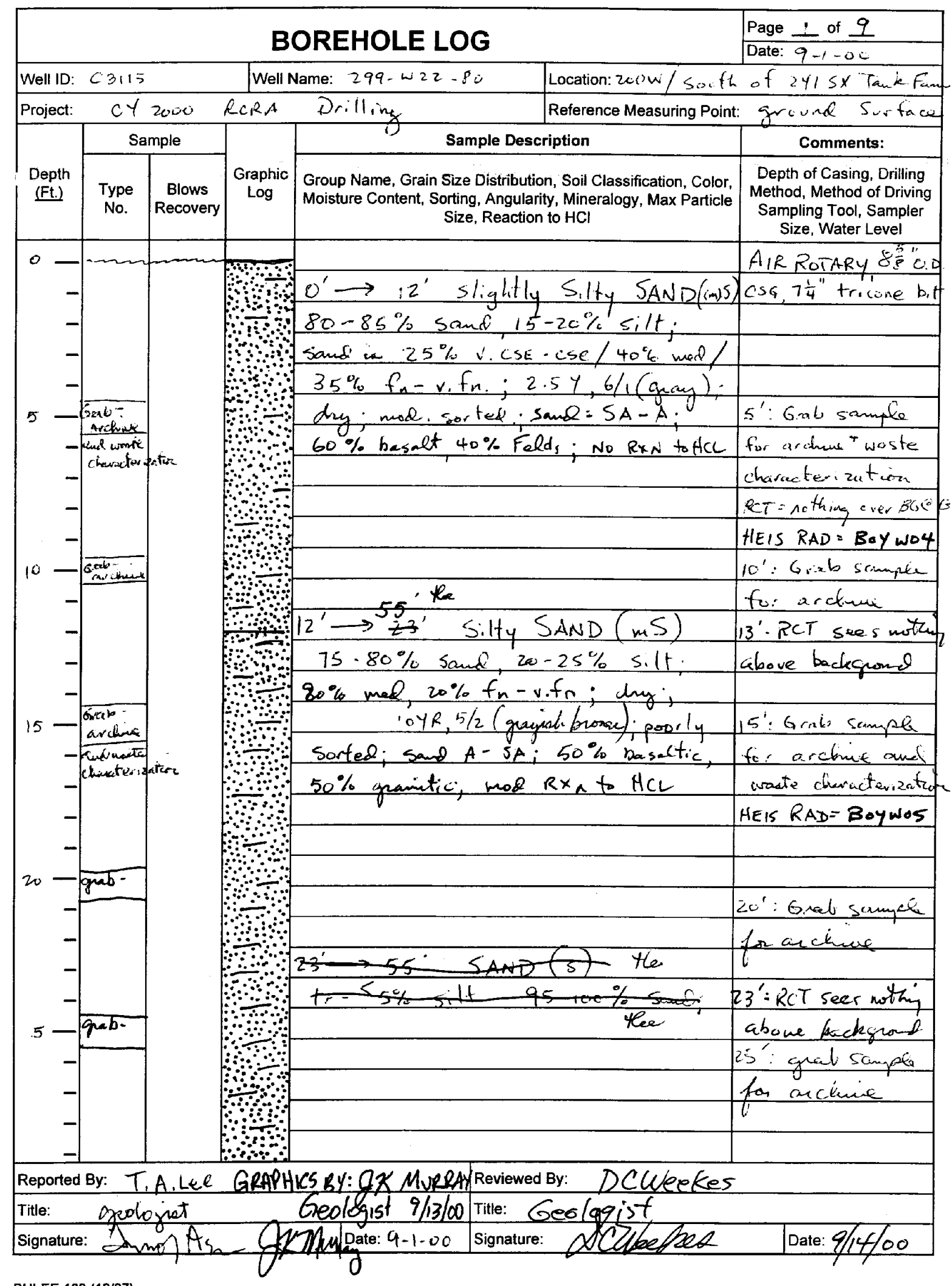

BHI-EE-183 (12/97) 


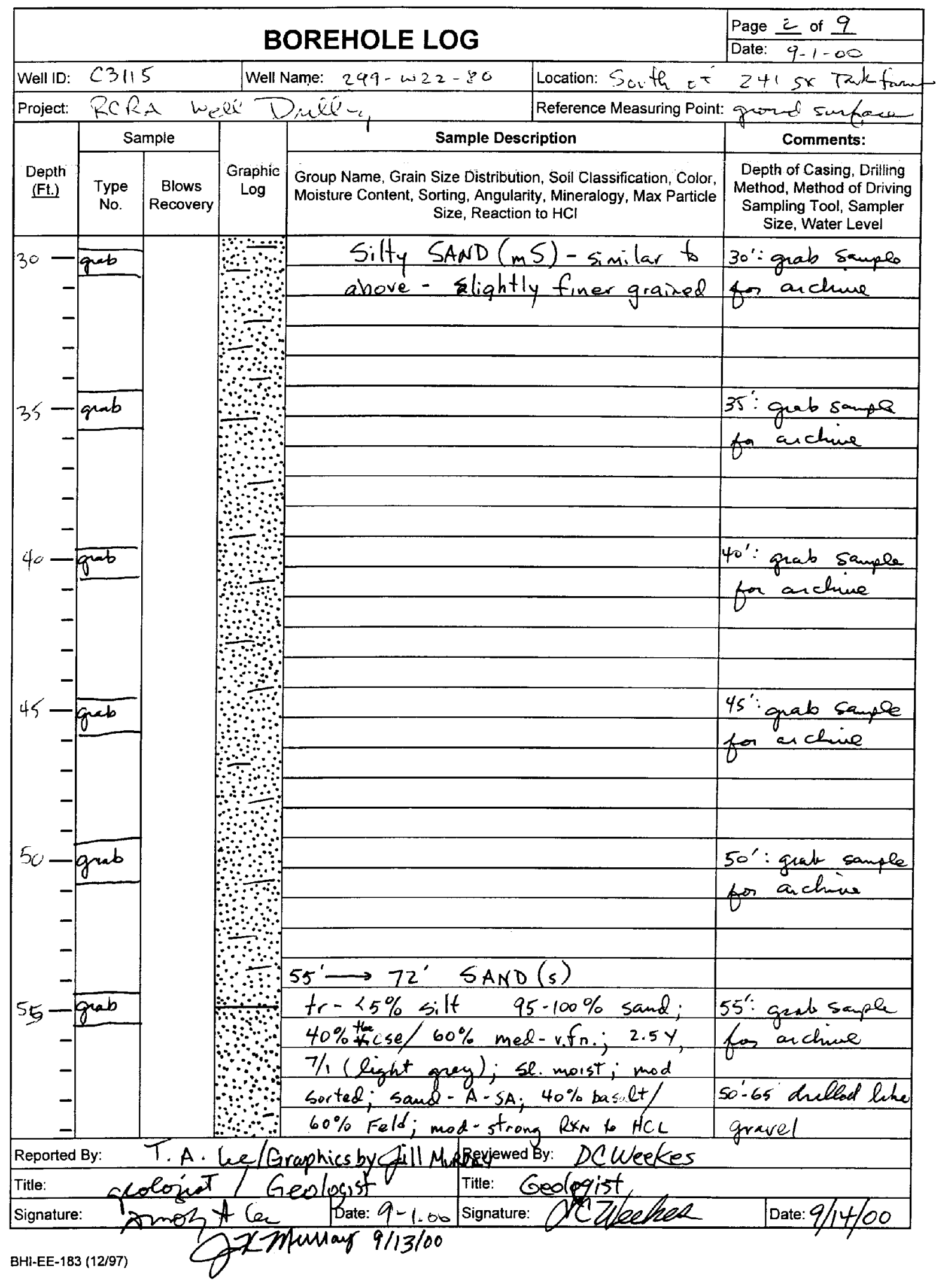




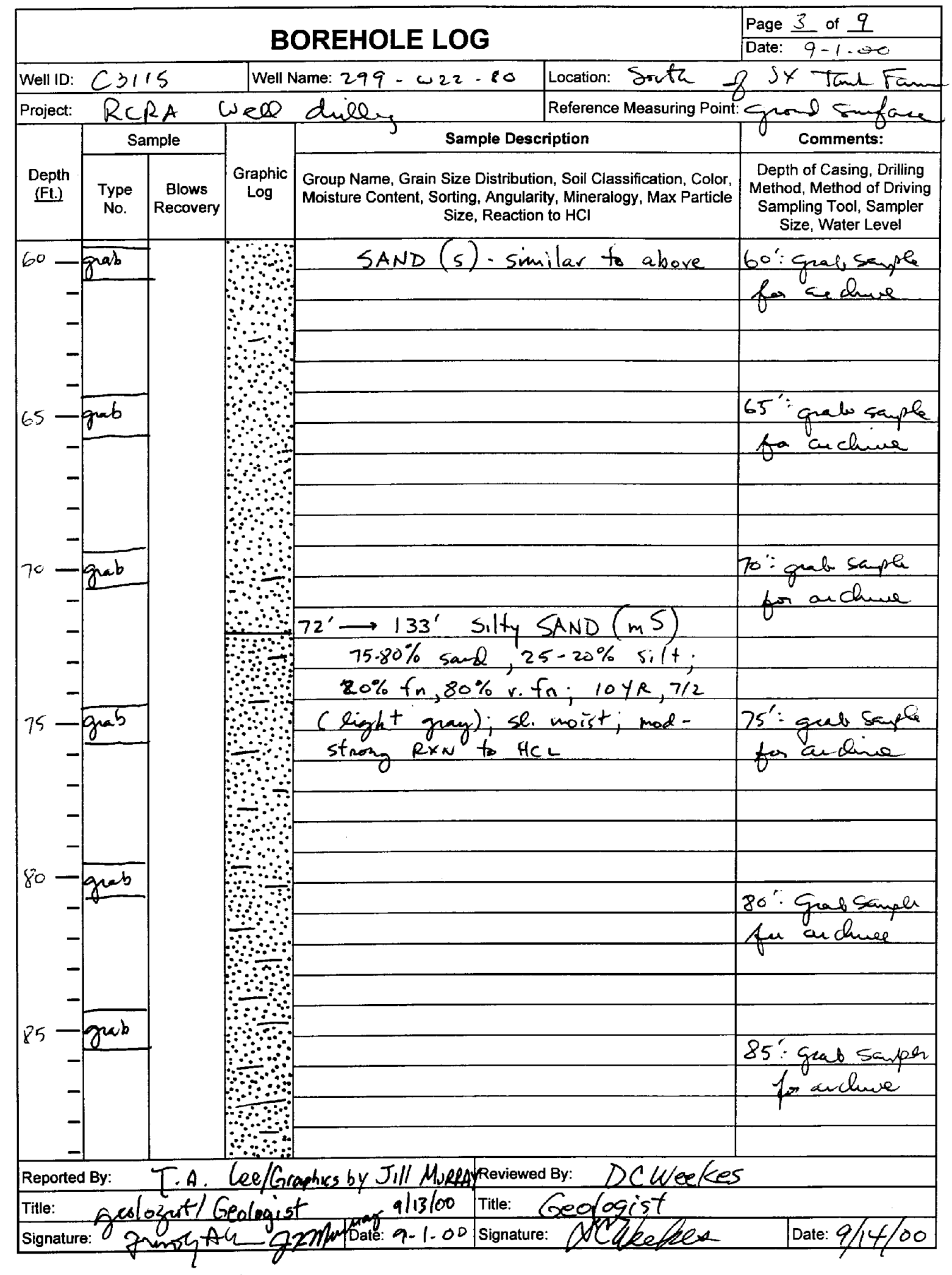

BHI-EE-183 (12/97) 


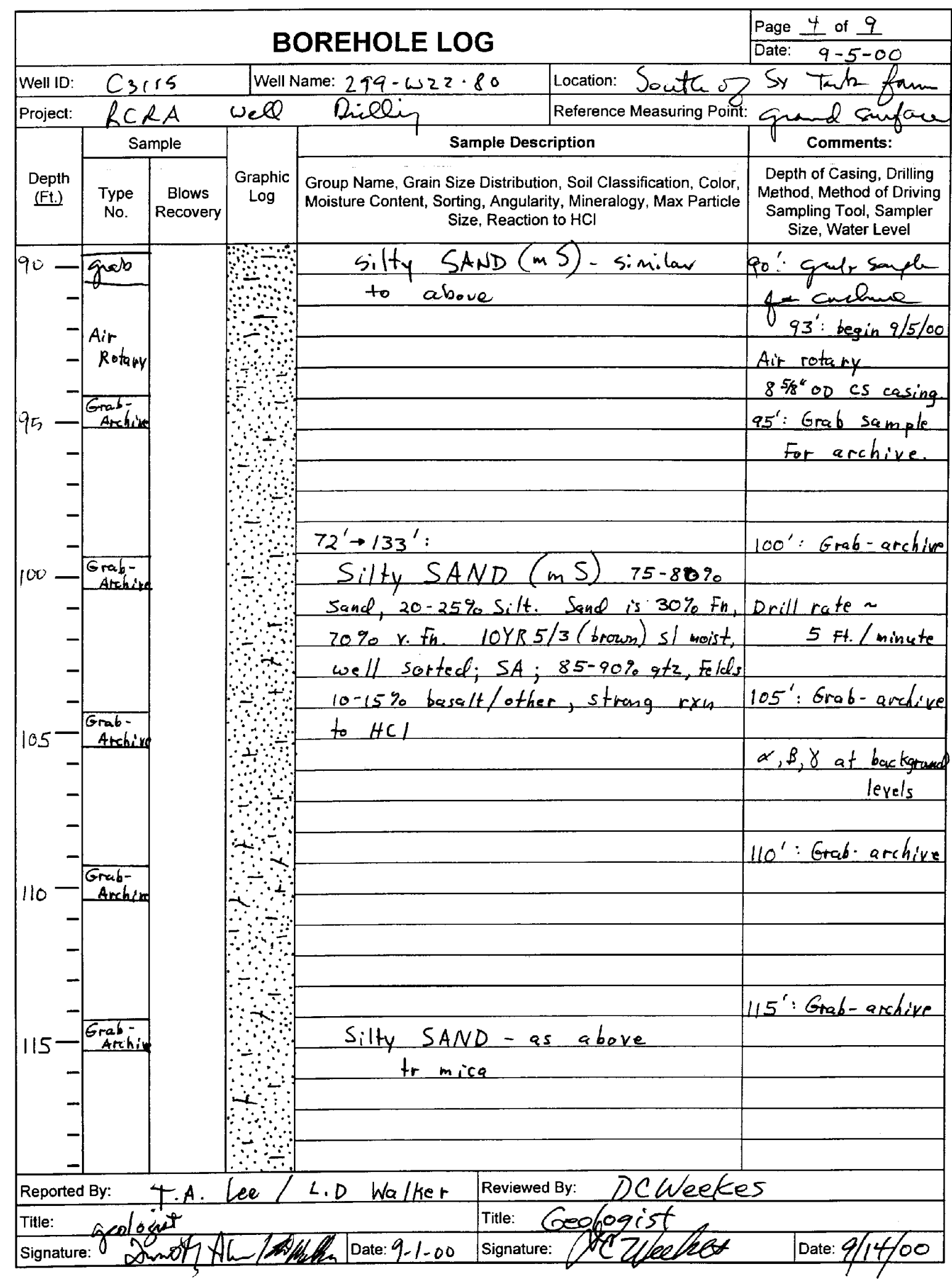

BHI-EE-183 (12/97) 


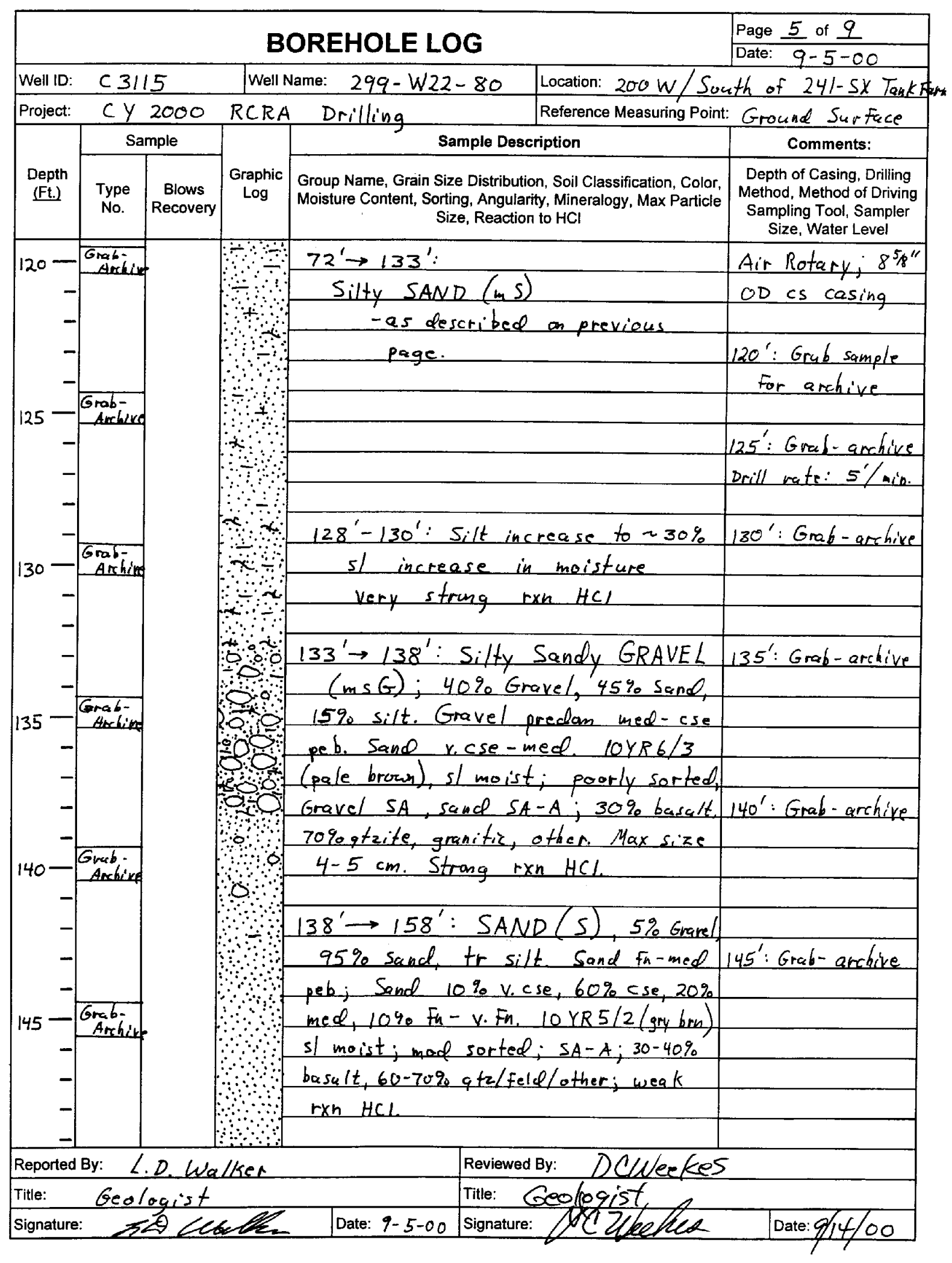

BHI-EE-183 (12/97) 


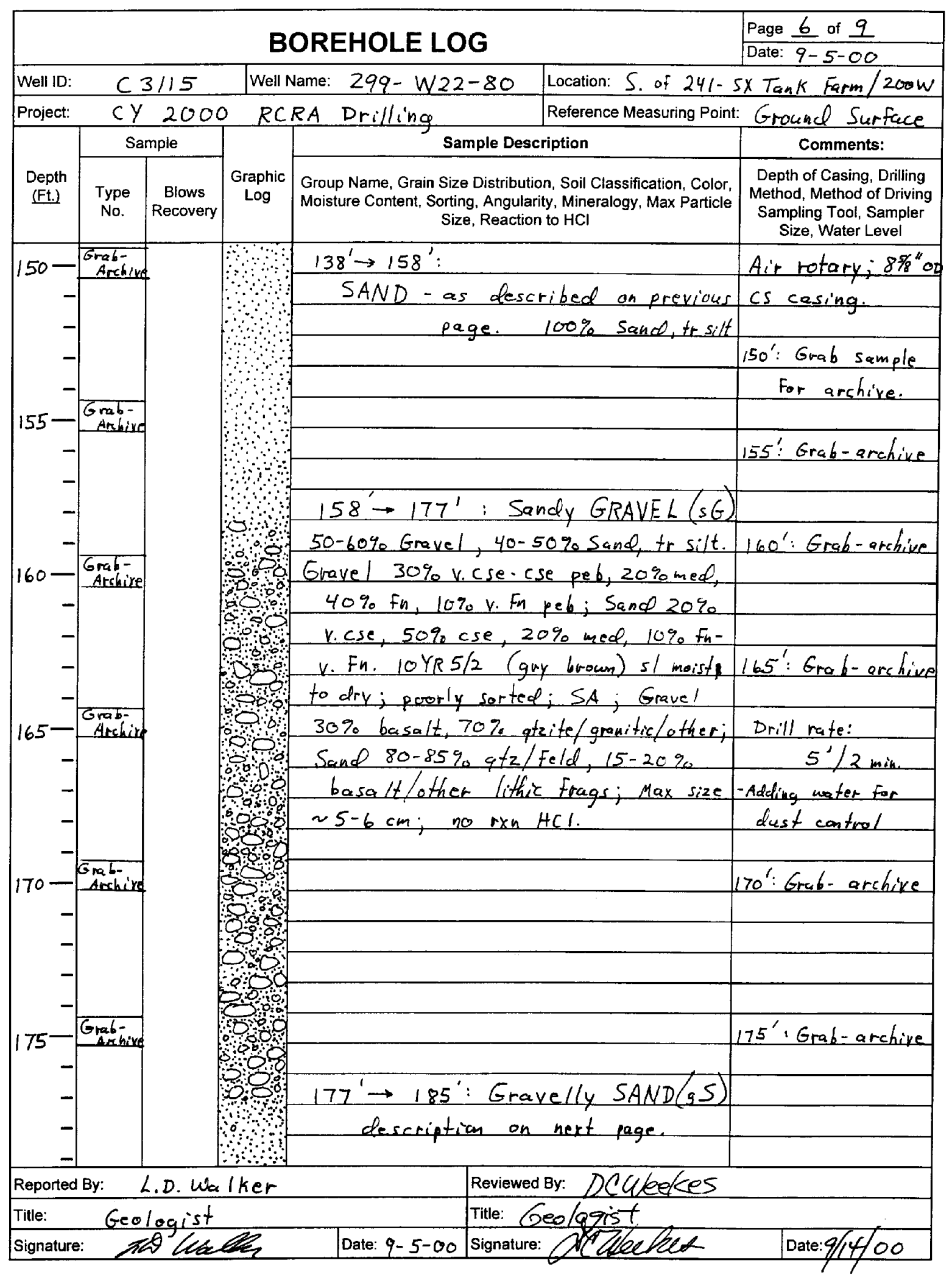

BHI-EE-183 (12/97) 


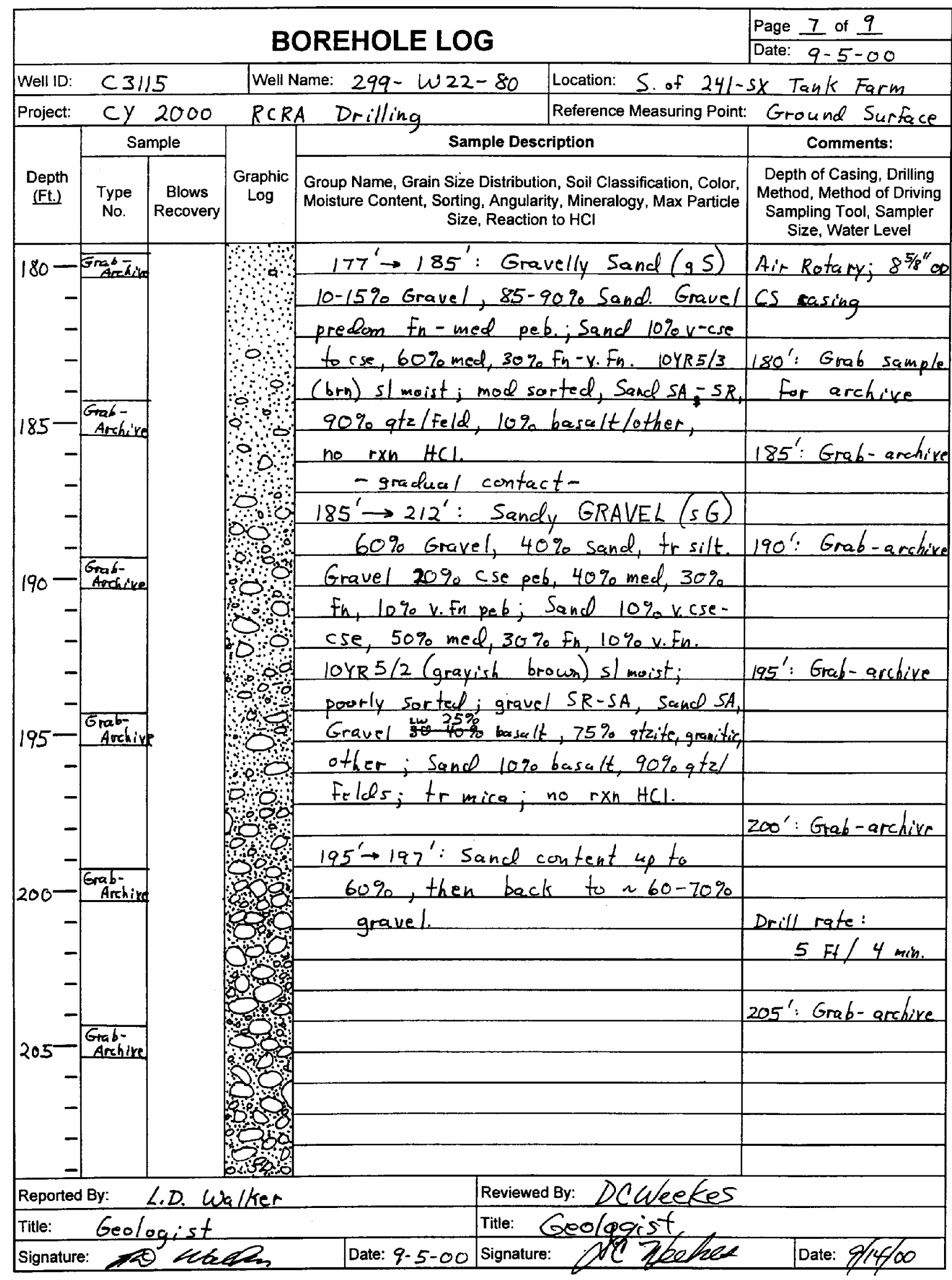

BHI-EE-183 (12/97) 


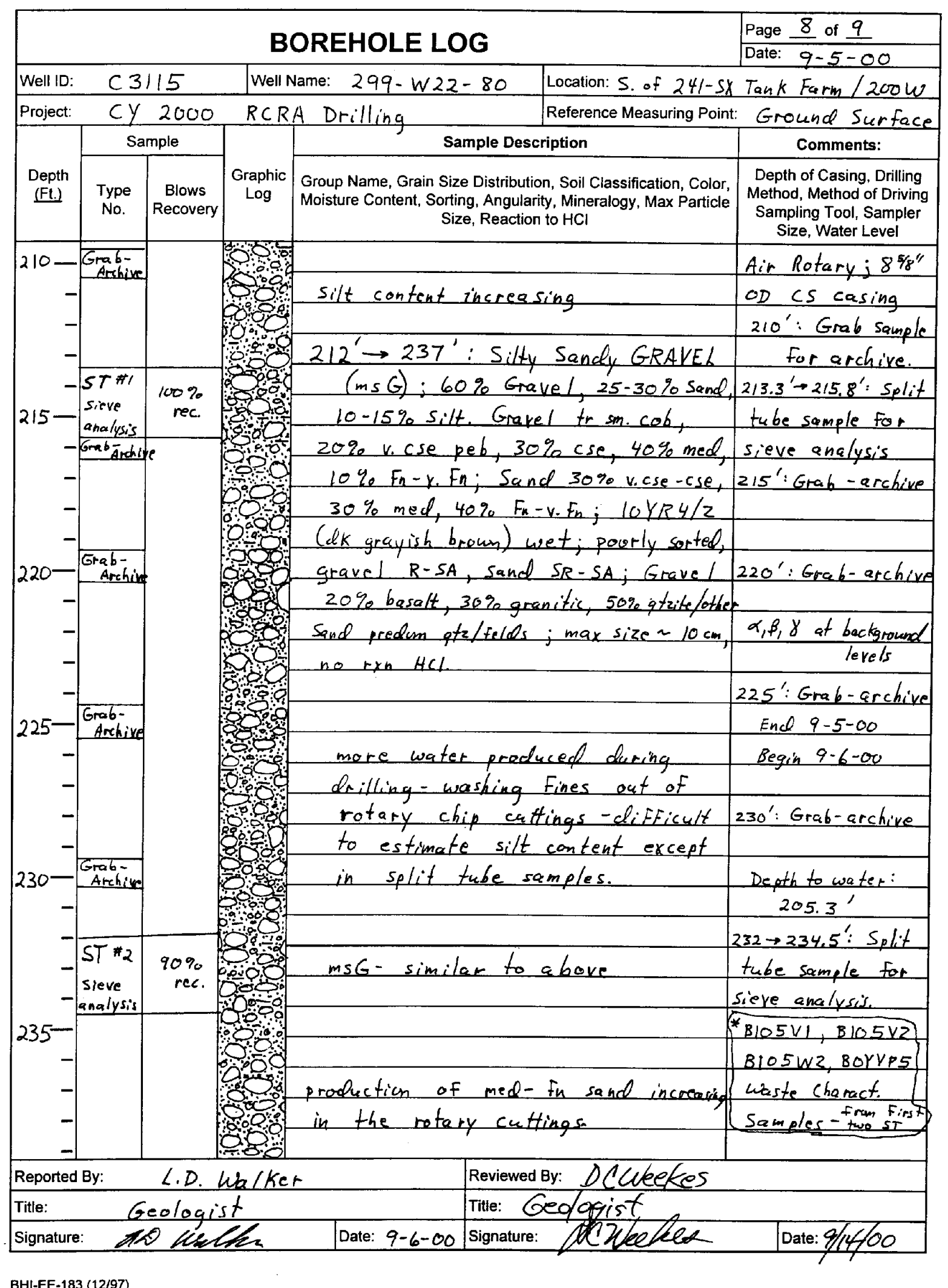

A. 11 


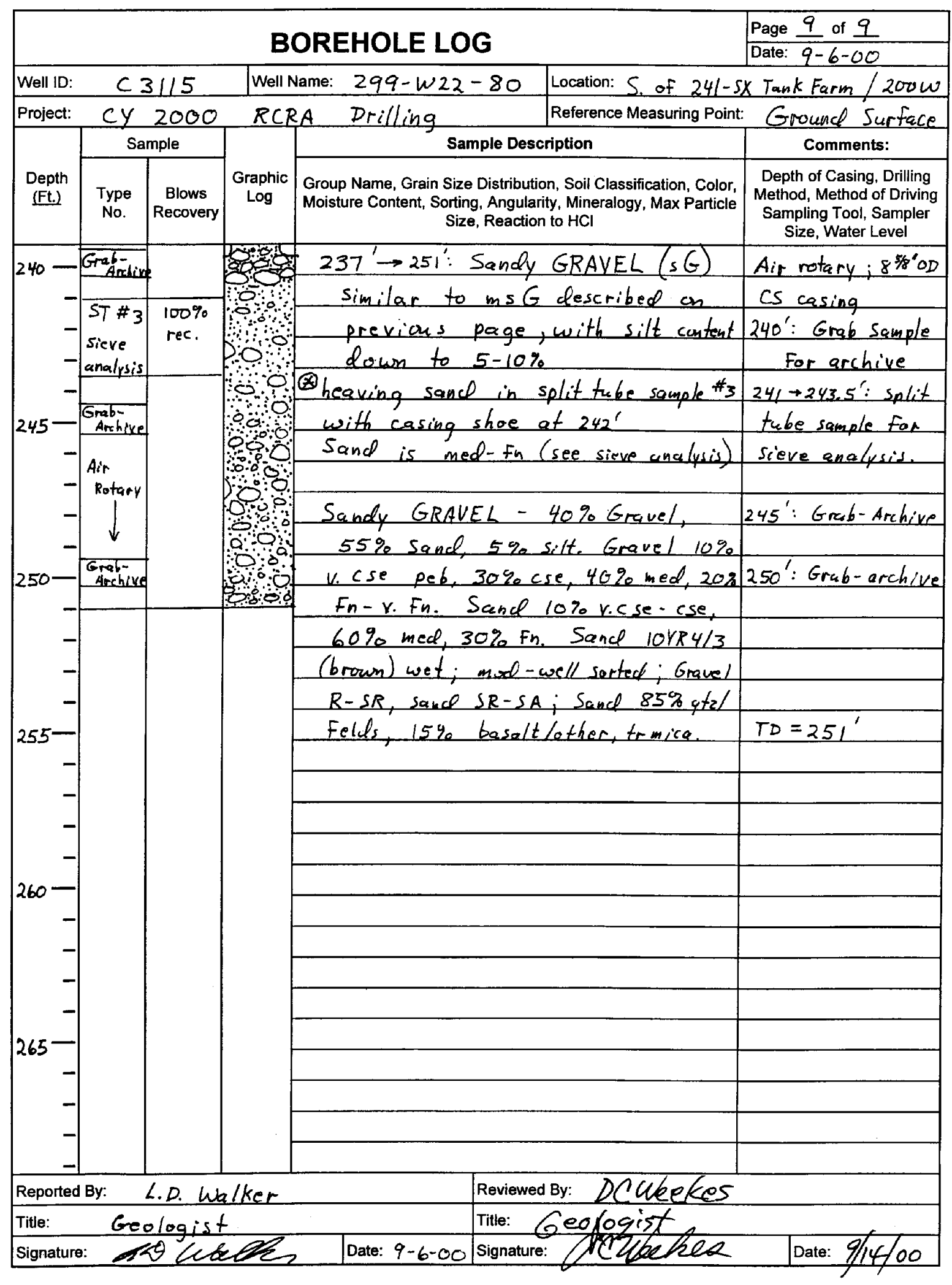

BHI-EE-183 (12/97)

A.12 


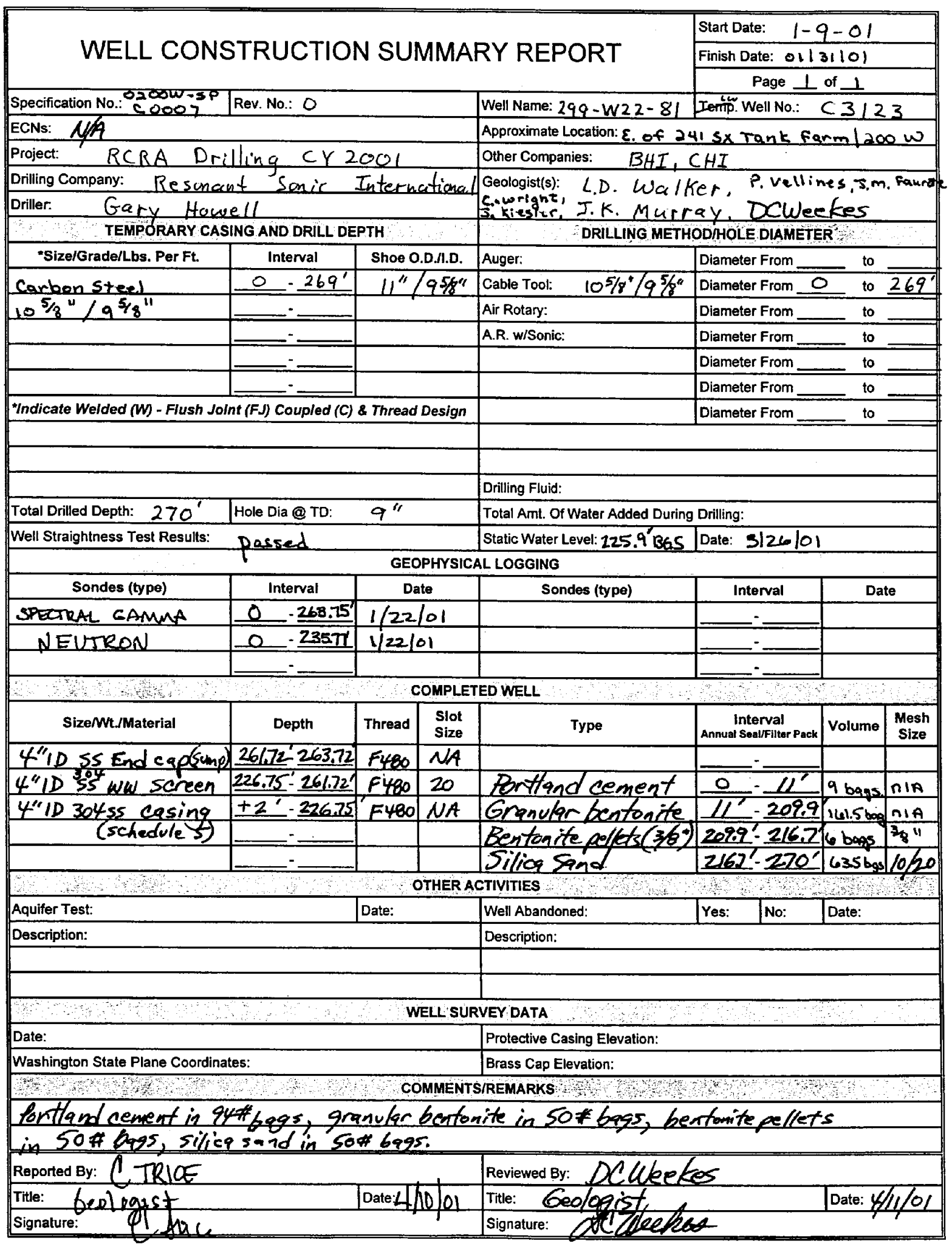

BHI-EE-181 (12/97) 


\begin{tabular}{|c|c|c|c|c|}
\hline \multicolumn{5}{|c|}{ WELL SUMMARY SHEET } \\
\hline \multirow{2}{*}{\multicolumn{2}{|c|}{$\begin{array}{l}\text { Well ID: } \\
\text { Location: EAST SIDE } 24123 \\
\text { L T TANKTARM }\end{array}$}} & \multicolumn{3}{|c|}{ Well Name: $299-$ W22-81 } \\
\hline & & \multicolumn{3}{|c|}{ Project. RC } \\
\hline \multirow{2}{*}{\multicolumn{2}{|c|}{ 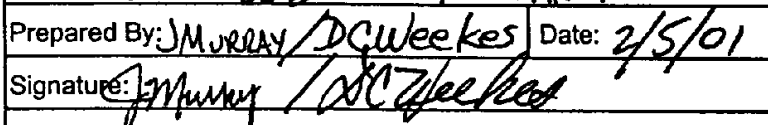 }} & \multicolumn{3}{|c|}{ Reviewed By: (Mnf aue rote } \\
\hline & & \multirow{2}{*}{\multicolumn{3}{|c|}{ Reviewed By: (Infaur ot }} \\
\hline \multicolumn{2}{|l|}{ CONSTRUCTION DATA } & & & \\
\hline Description & Diagram & $\begin{array}{c}\text { Depht in } \\
\text { Feet } \\
\text { Fet }\end{array}$ & shic & Lithologic Description \\
\hline 6-in dia protective ss & \multirow{20}{*}{ ( } & & \multirow{6}{*}{$\frac{3}{36}$} & $0^{0}-9.5^{\prime}$ SILTY SANDY GRAVEL \\
\hline casing set I 'above the & & \multirow{19}{*}{-} & & \\
\hline$T-m$ & & & & $19 J_{L}$ \\
\hline 4 -in ID sch $555304 \mathrm{~L}$ & & & & $19^{\prime}-34^{\prime}$ SAND \\
\hline \multirow{2}{*}{$\begin{array}{l}\text { well casing: } \\
+2^{n} \rightarrow 226.75^{\prime}\end{array}$} & & & & \\
\hline & & & & $34^{\prime}-40^{\prime} S_{H G H T H Y S_{1 R T}} S$ \\
\hline \multirow{2}{*}{$\begin{array}{l}\text { Portland cement grout: } \\
0^{\prime} \rightarrow 1 /\end{array}$} & & & & $40^{\prime}-45^{\prime}$ SUGHTY SILT \\
\hline & & & & $\begin{array}{l}\text { GRAVELY SAND } \\
45^{\prime}-48^{\prime} \text { S IITY SANDI GPANE }\end{array}$ \\
\hline \multirow[t]{2}{*}{$\begin{array}{l}\text { Granular bentonite: } \\
11^{\prime} \rightarrow 209.9^{\prime}\end{array}$} & & & & 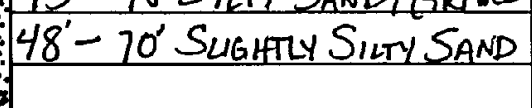 \\
\hline & & & & 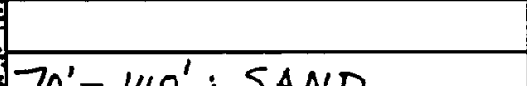 \\
\hline \multirow{2}{*}{  } & & & & \\
\hline & & & & \\
\hline & & & & \\
\hline & & & & \\
\hline & & & & \\
\hline & & & & \\
\hline & & & & \\
\hline II depthsi & & & & \\
\hline $\mathbb{1}$ tem & & & & \\
\hline from $t$ & & & & \\
\hline
\end{tabular}

BHI-EE-189 (12/97) 


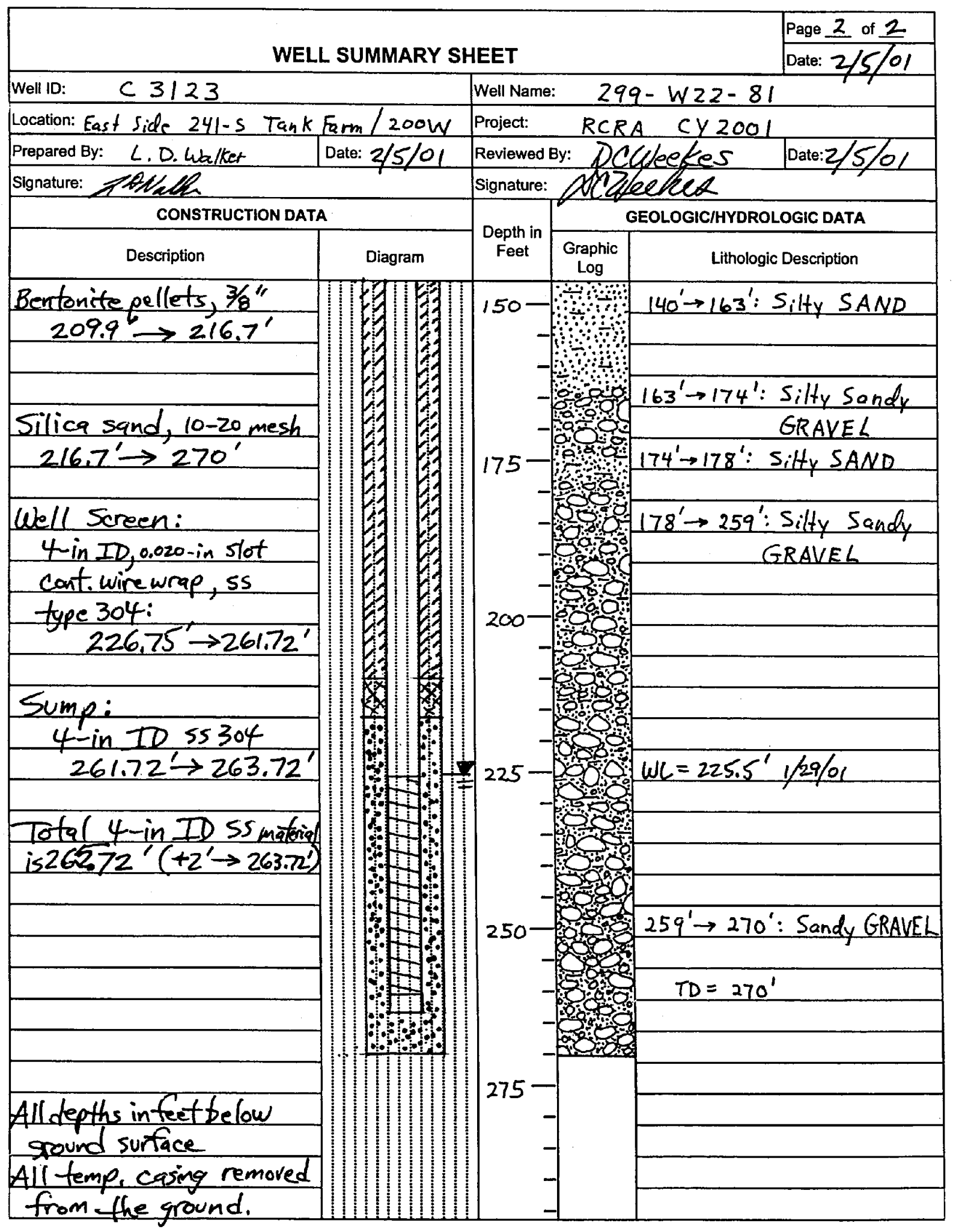

BHI-EE-189 (12/97) 


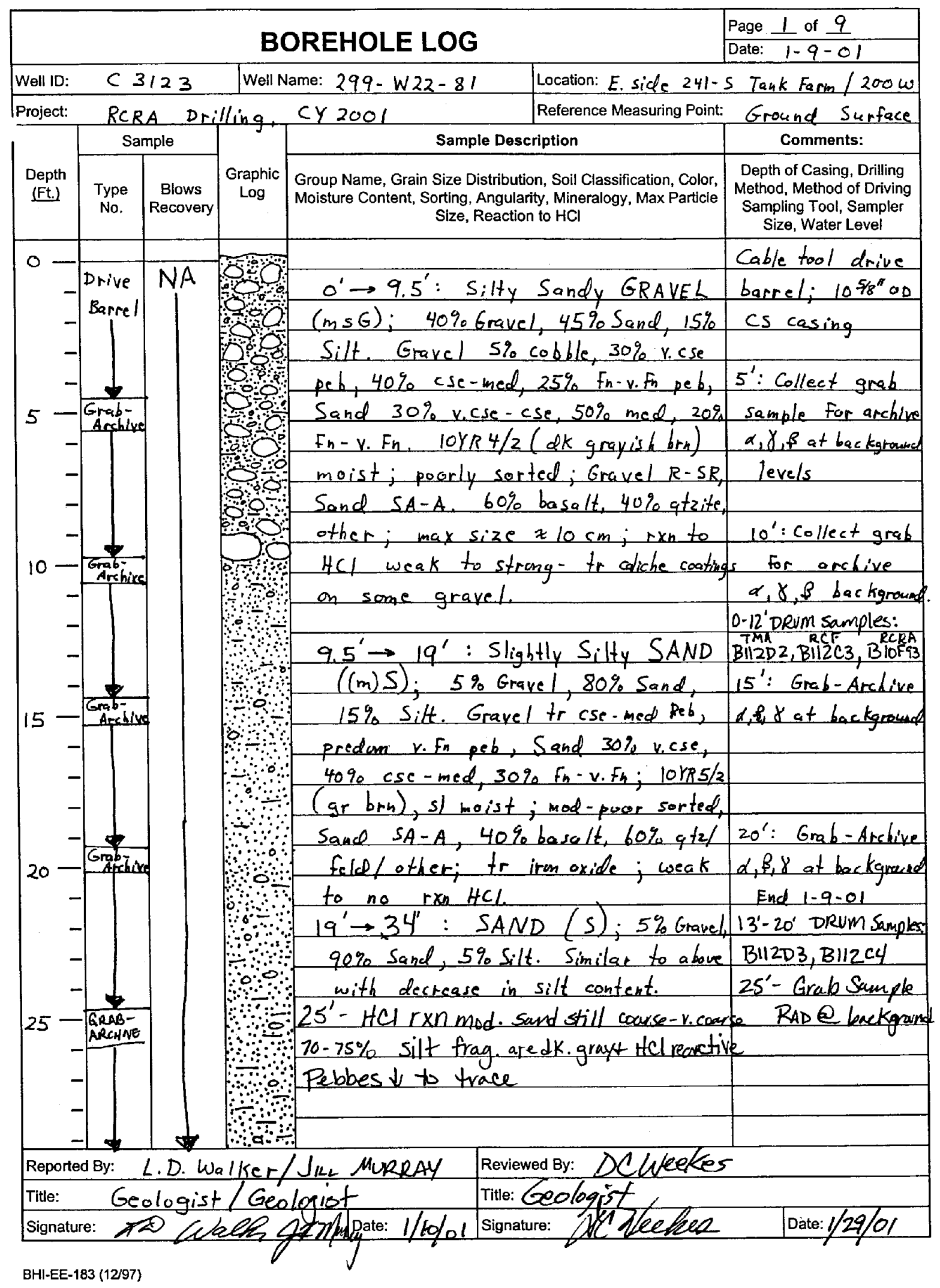




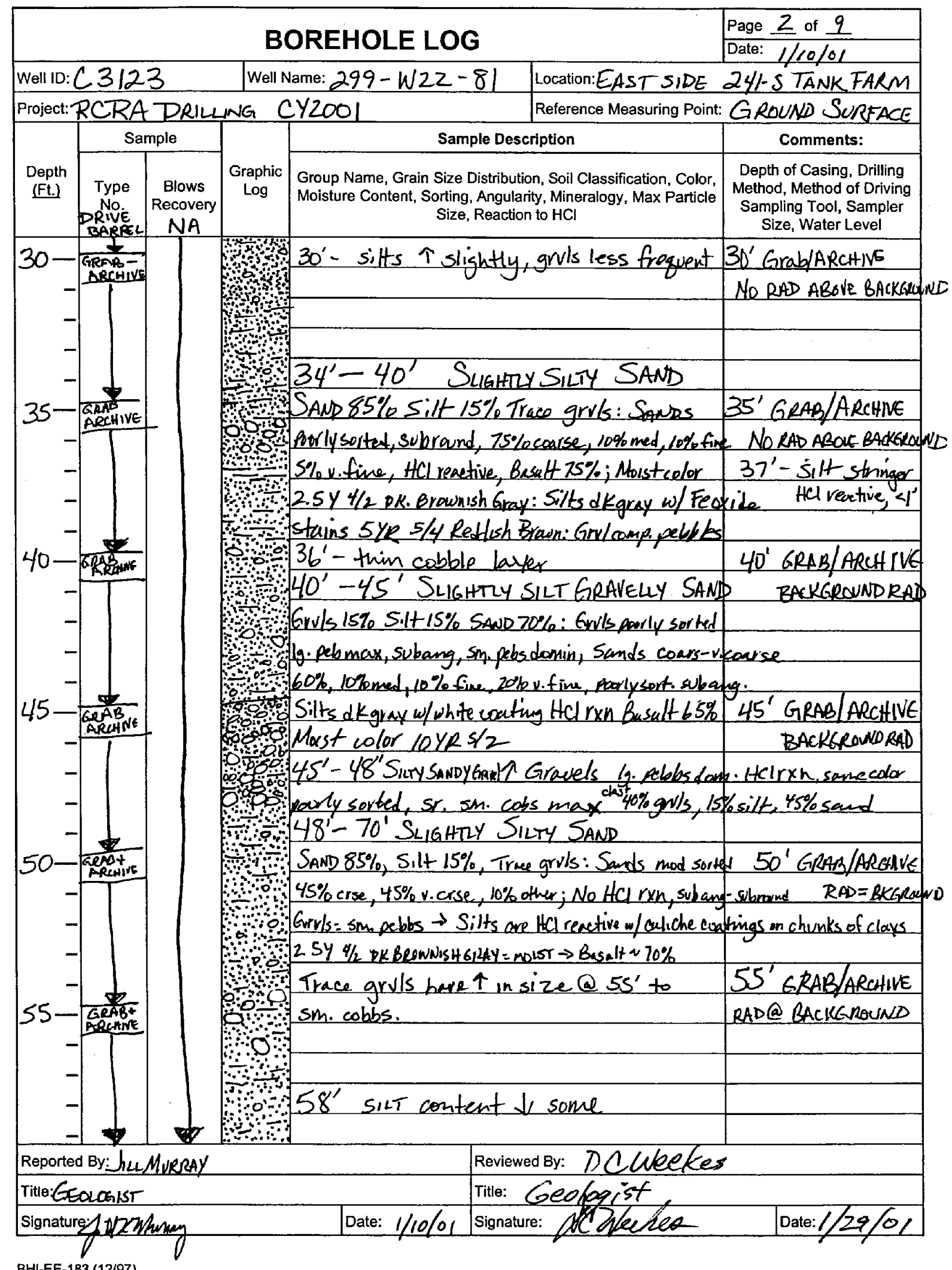









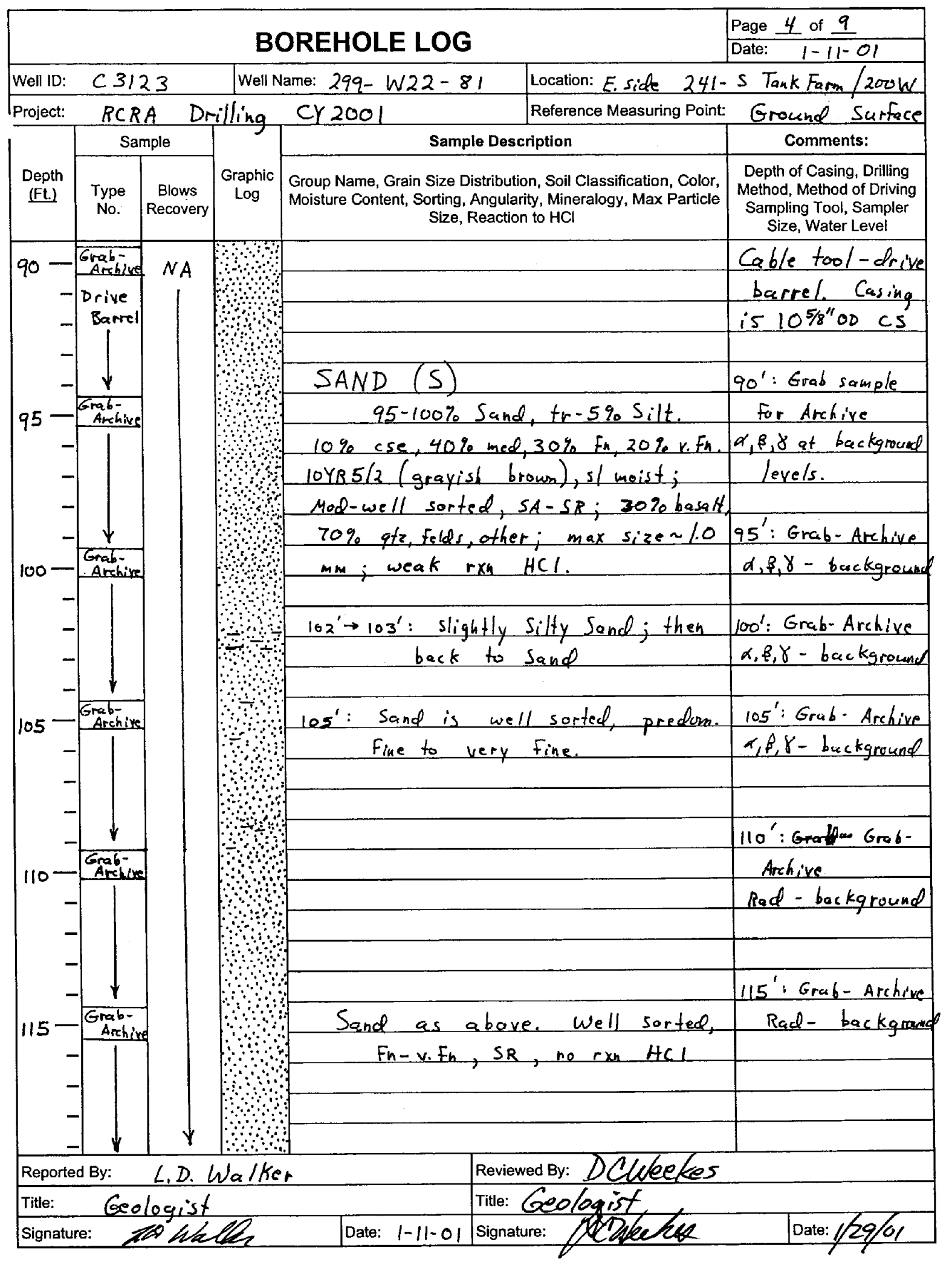

BHI-EE-183 (12/97) 


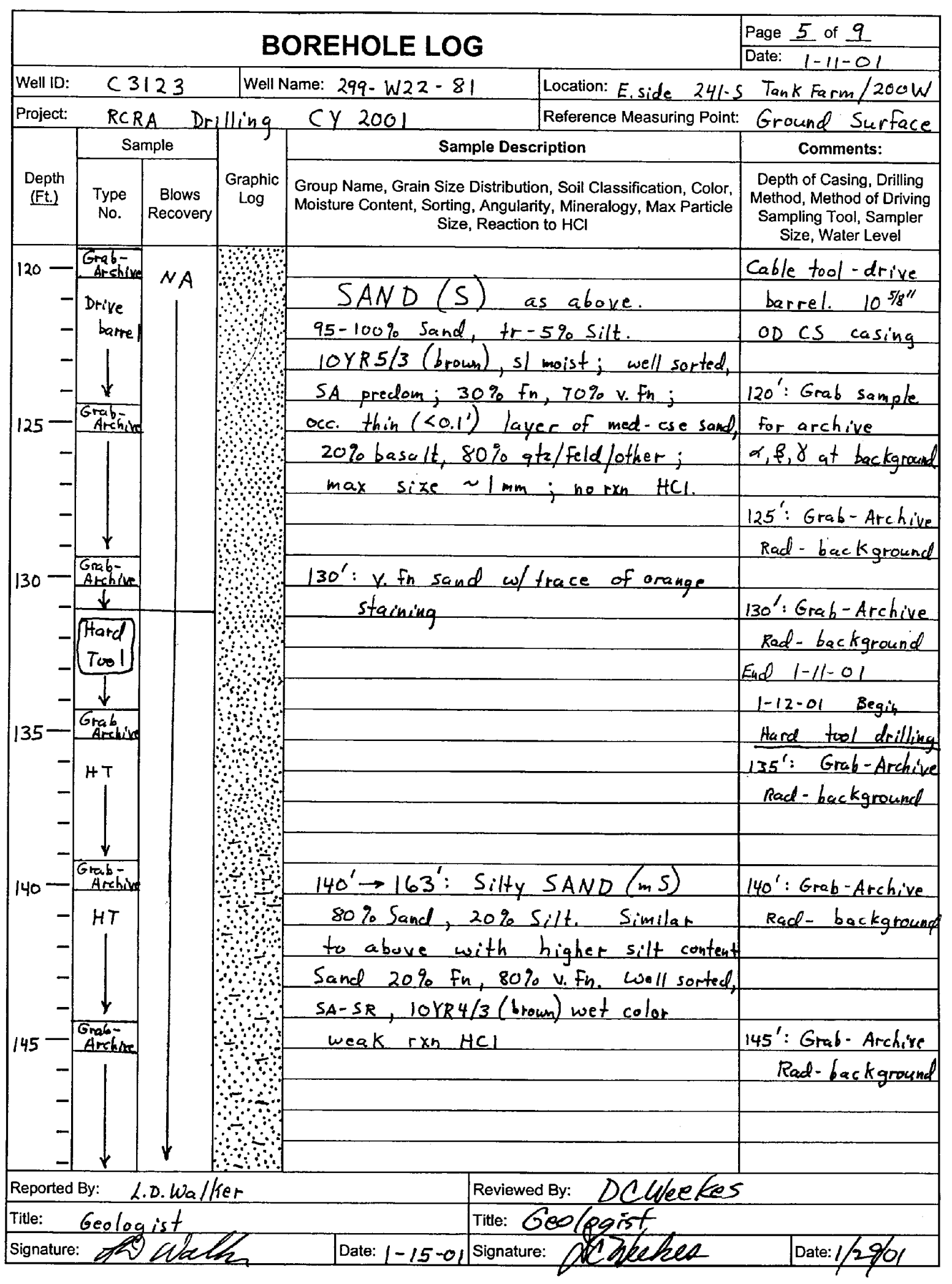

BHI-EE-183 (12/97) 




BHI-EE-183 (12/97) 


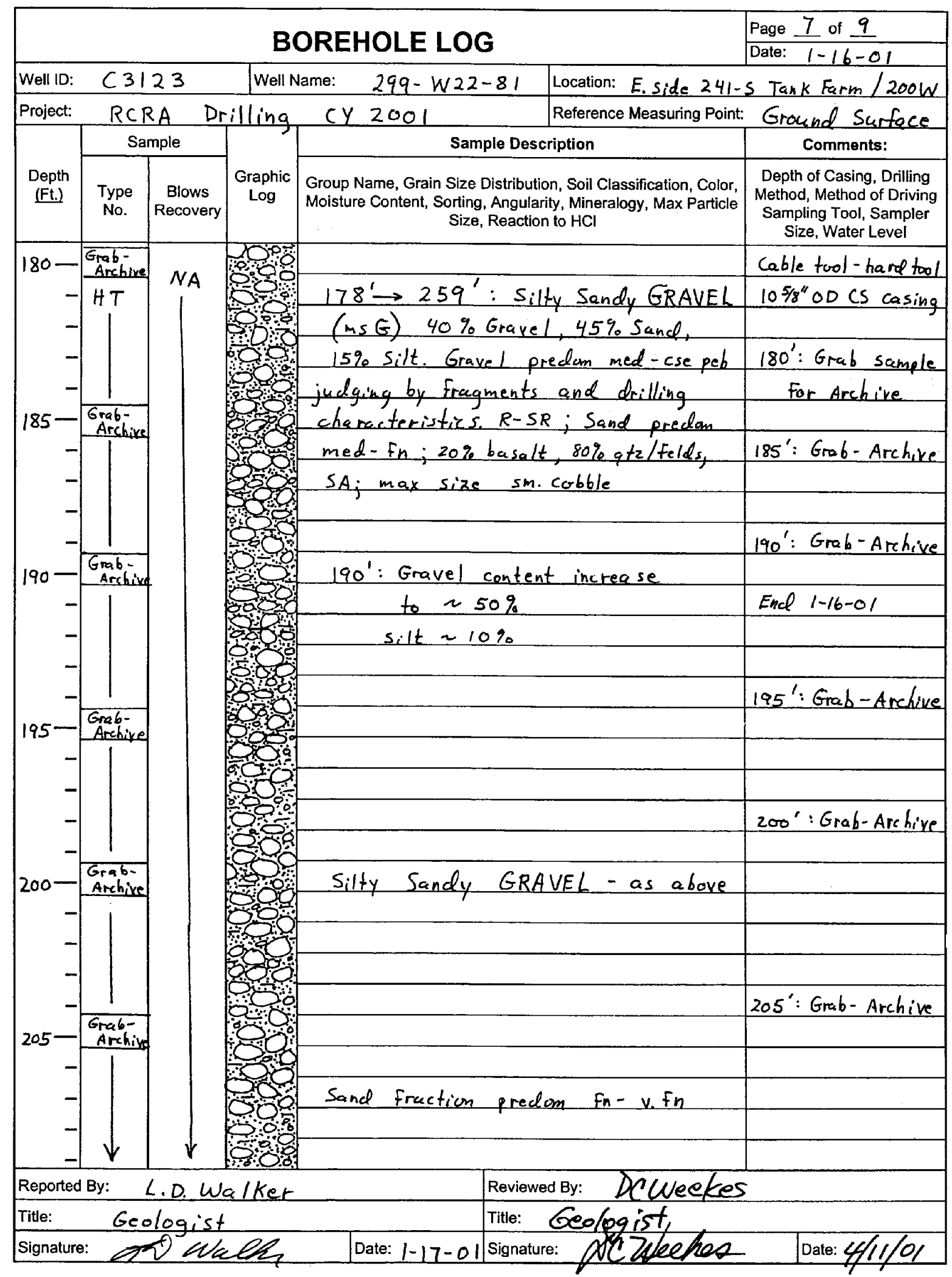

BHI-EE-183 (12/97) 


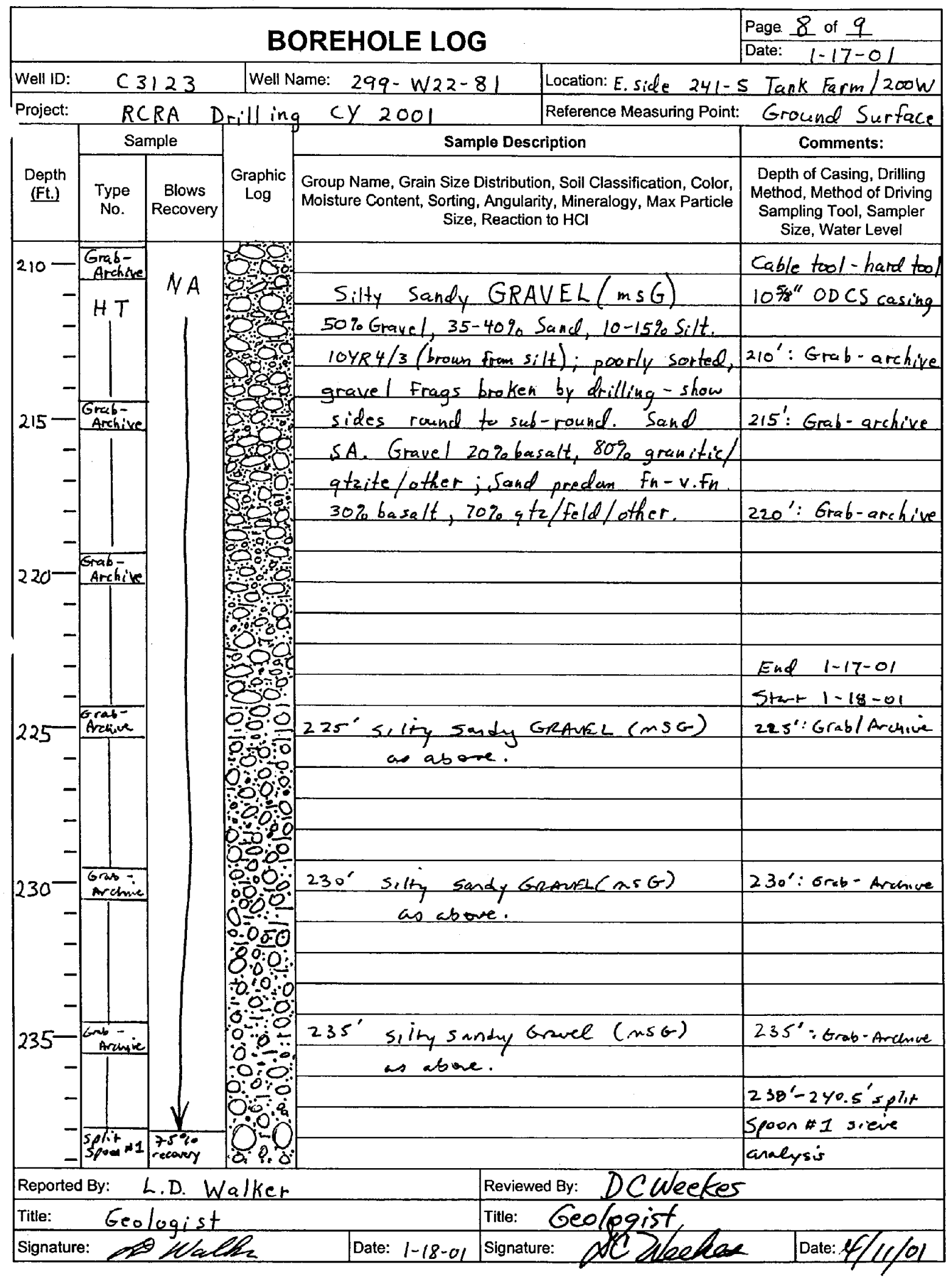

BHI-EE-183 (12/97) 


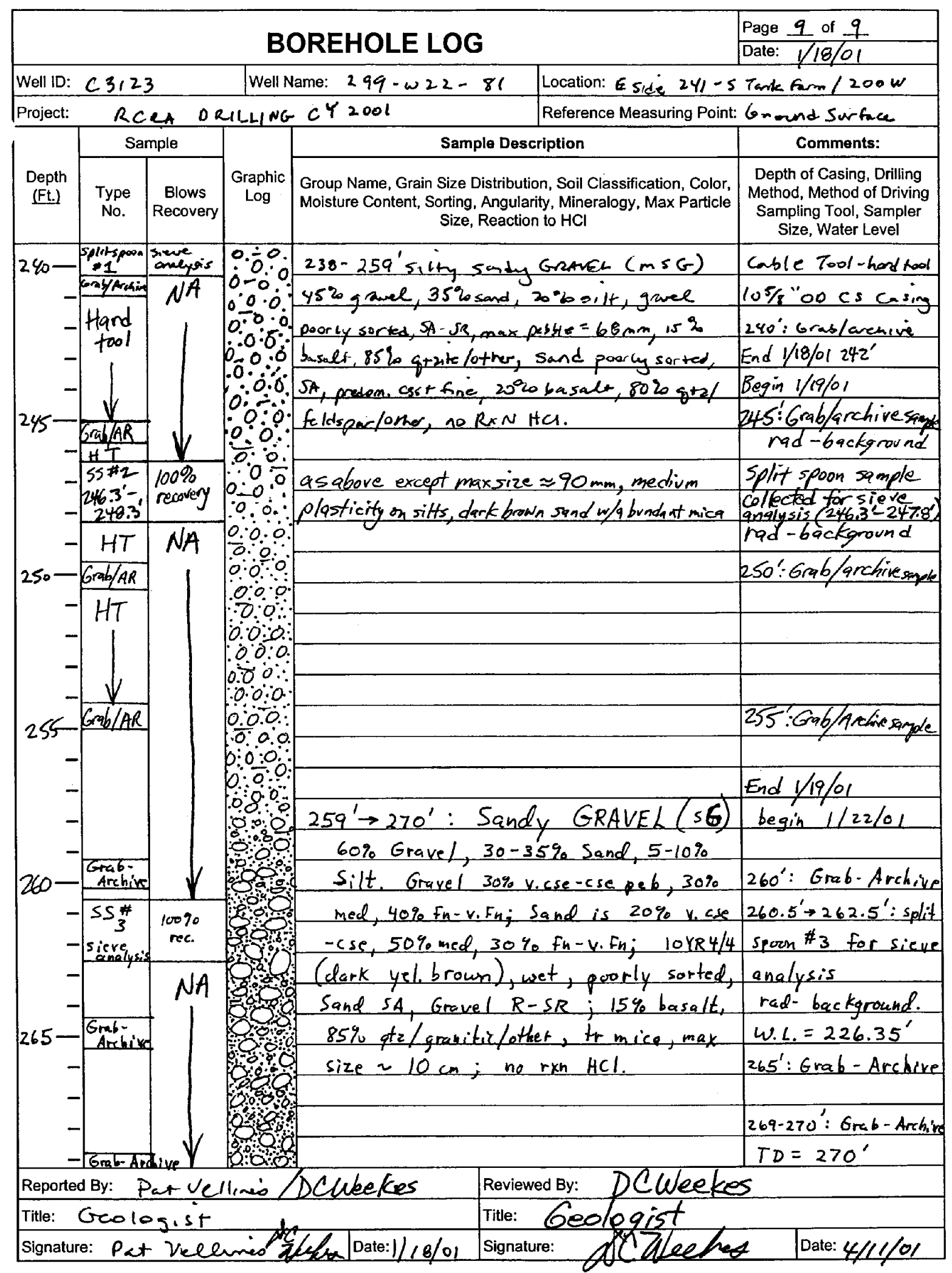

BHI-EE-183 (12/97) 


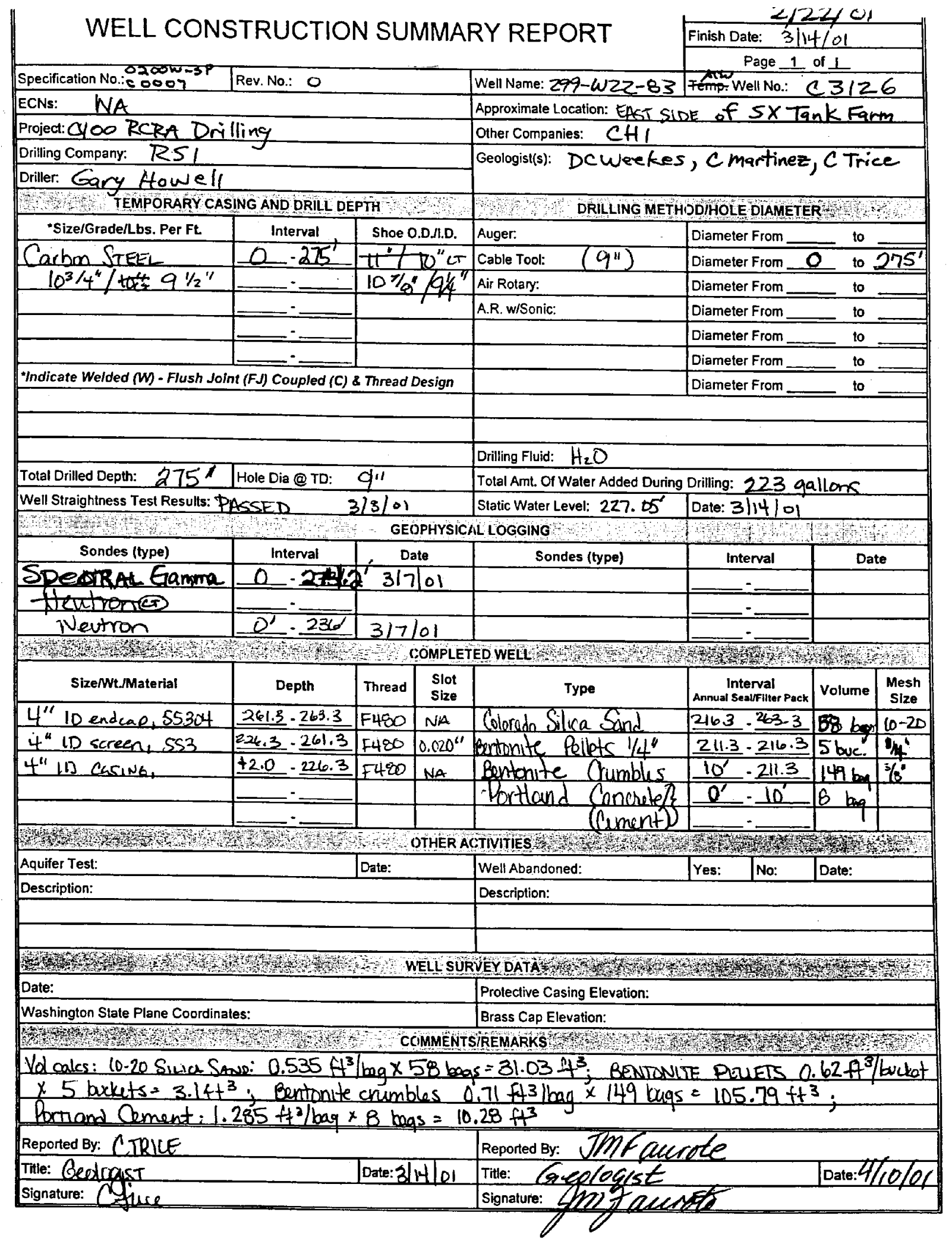

BHI-EE-181 (12/97) 


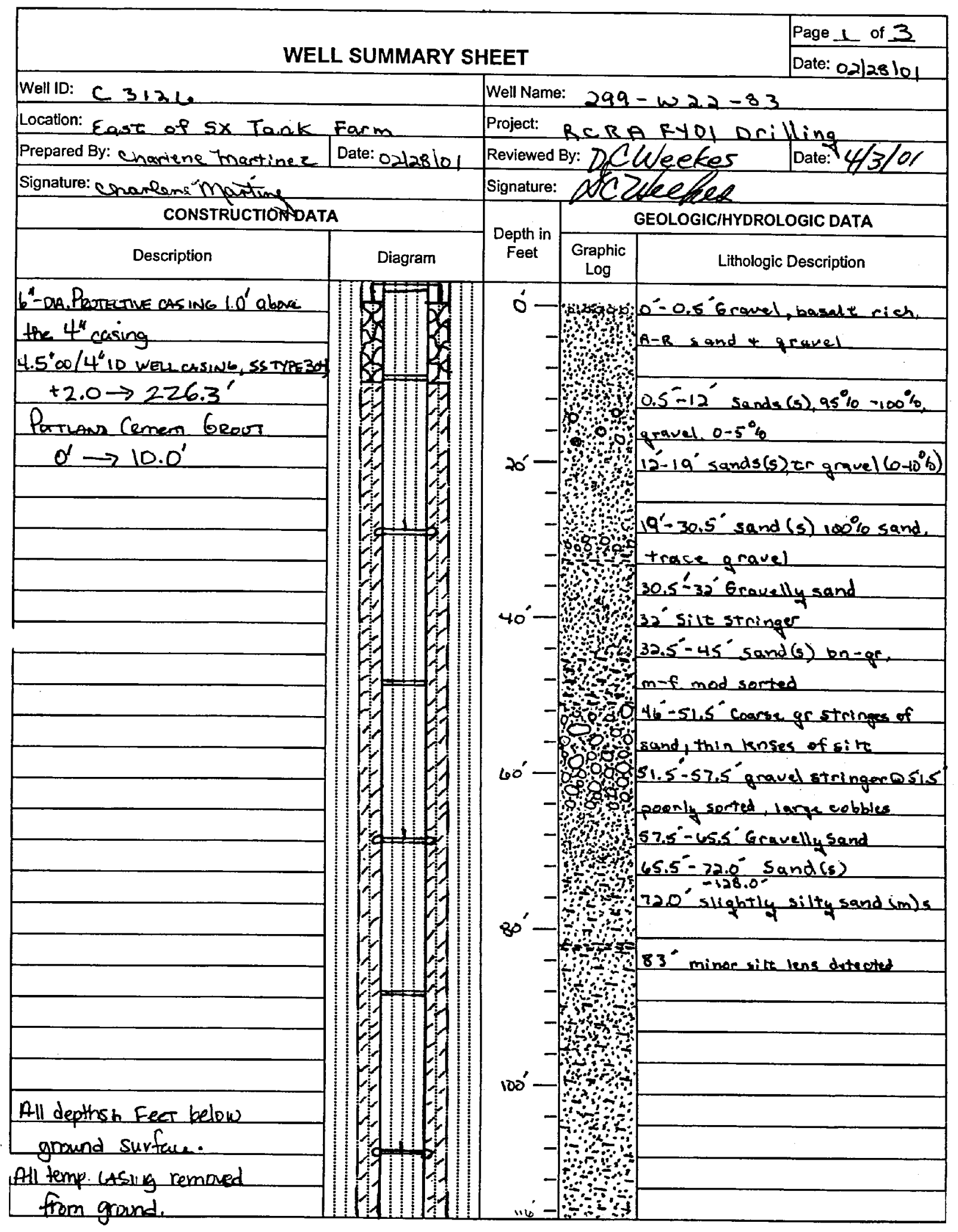

BHI-EE-189 (12/97) 


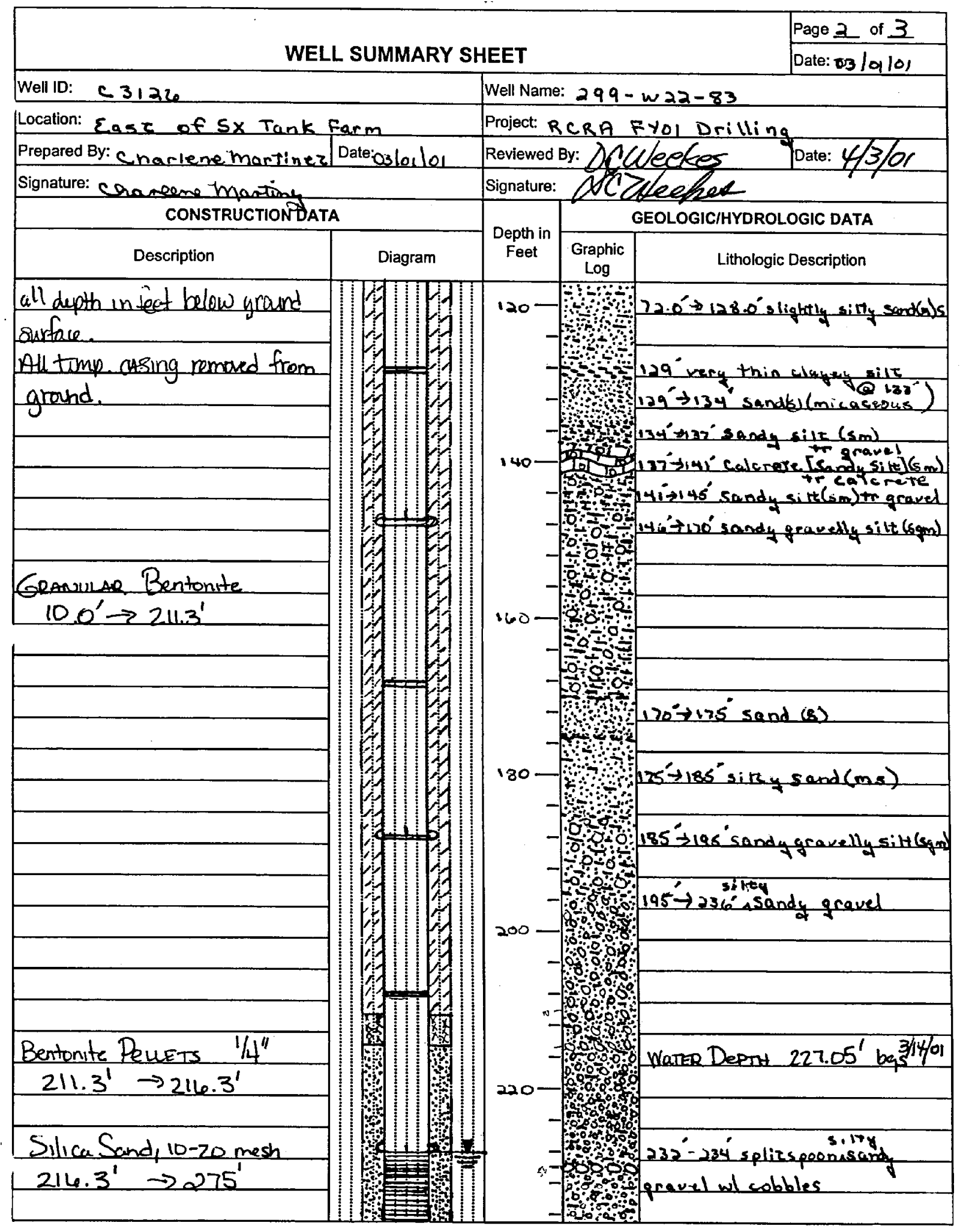

BHI-EE-199 (12/97) 


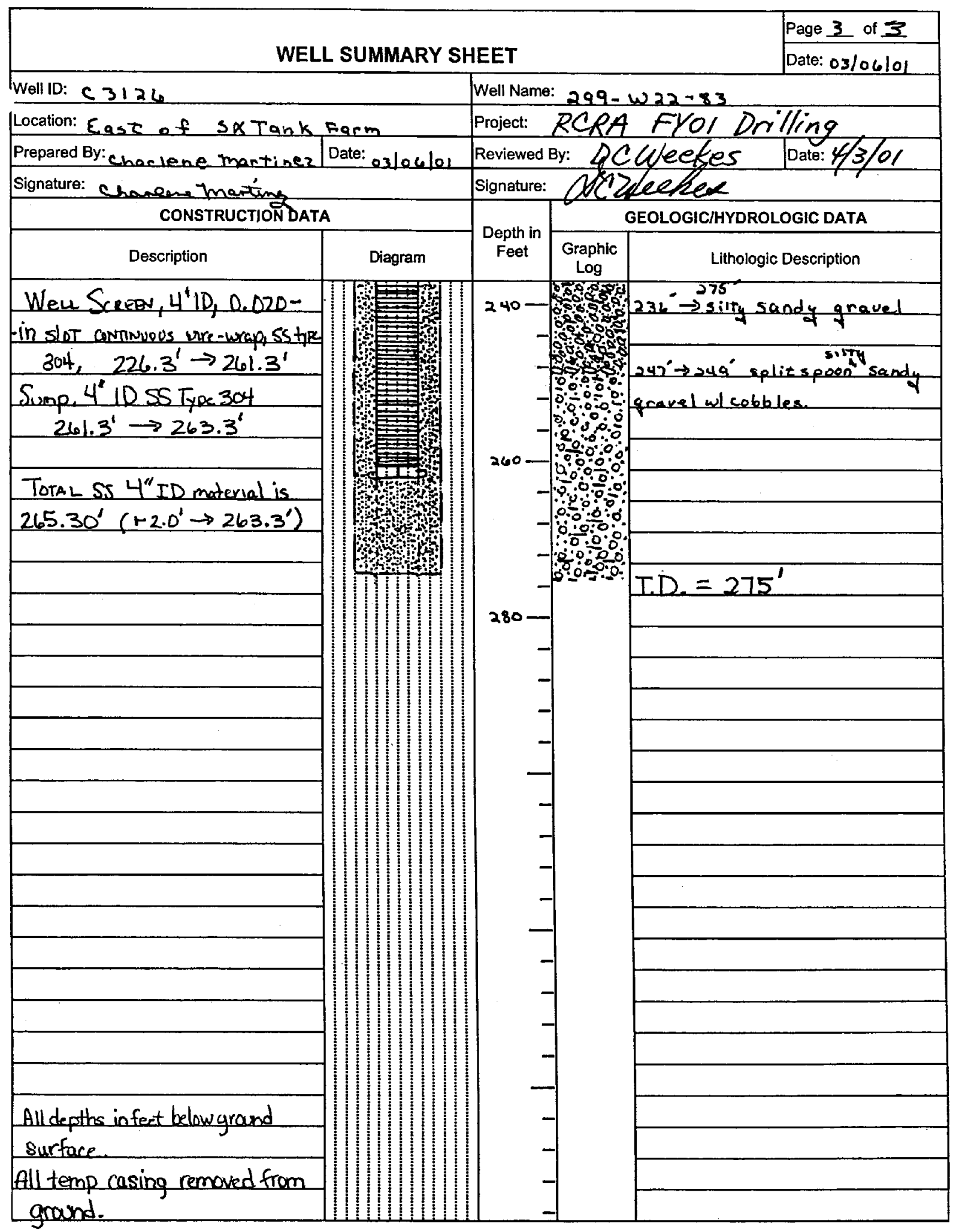

BHI-EE-189 (12/97) 


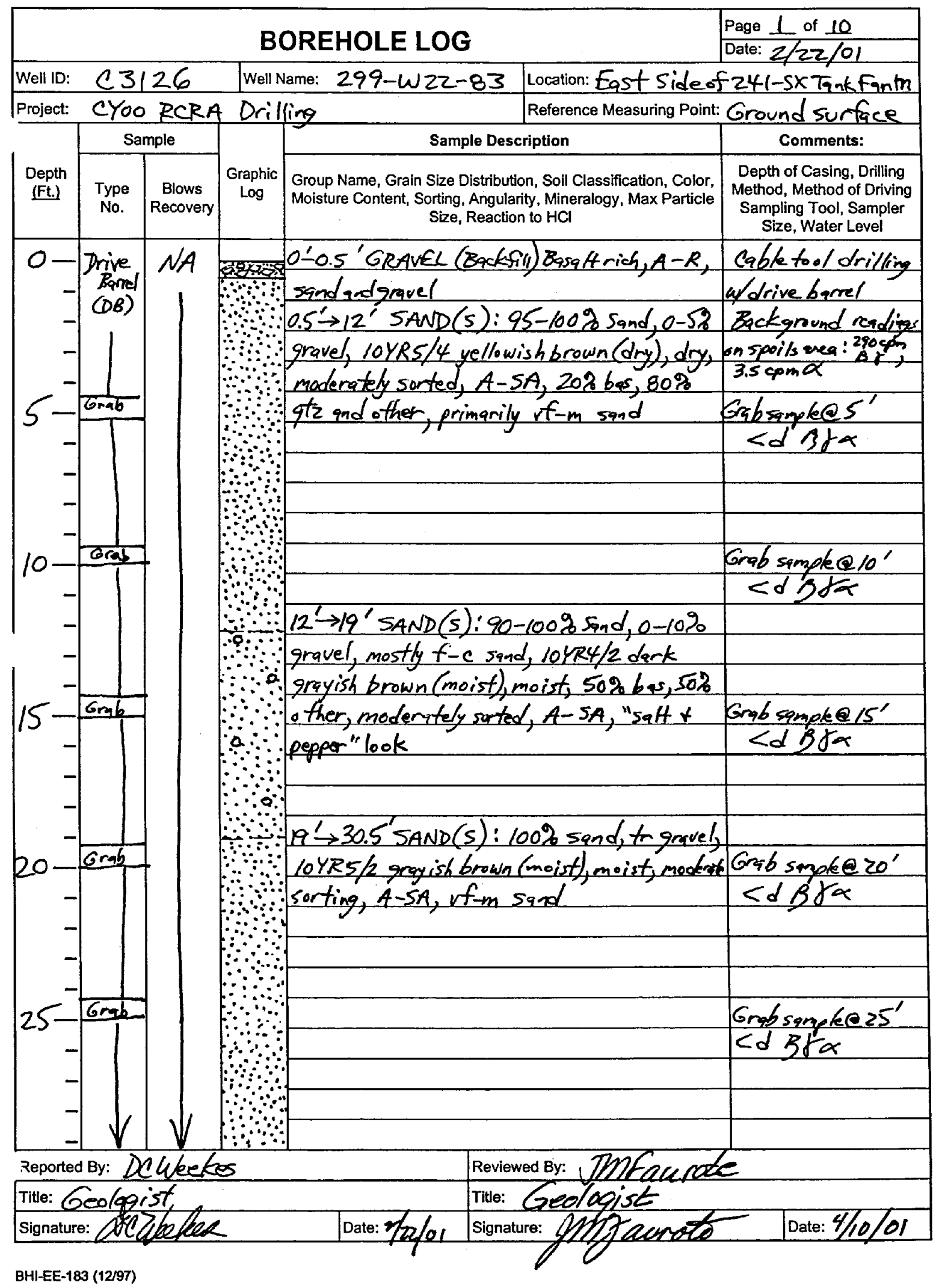




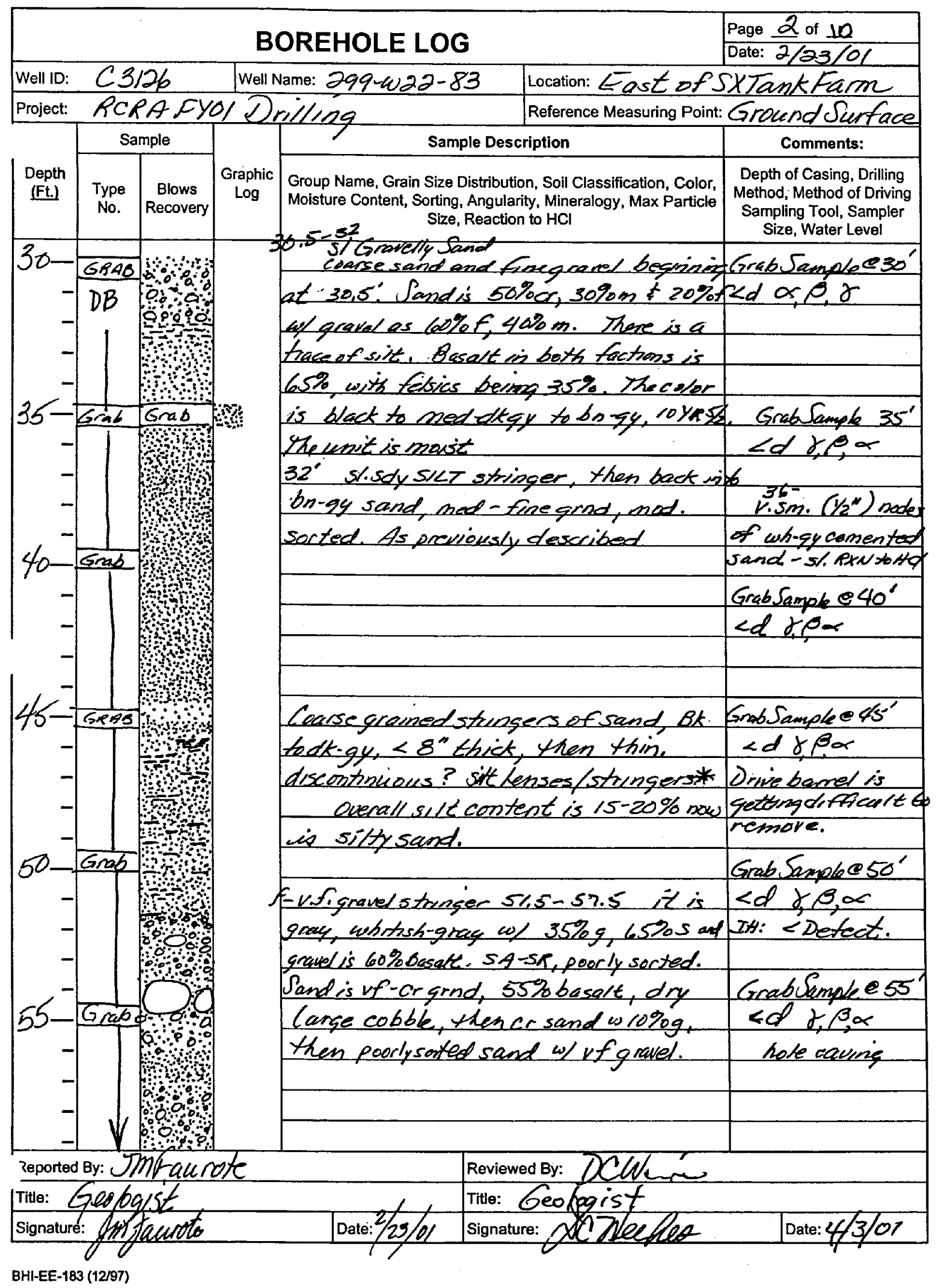




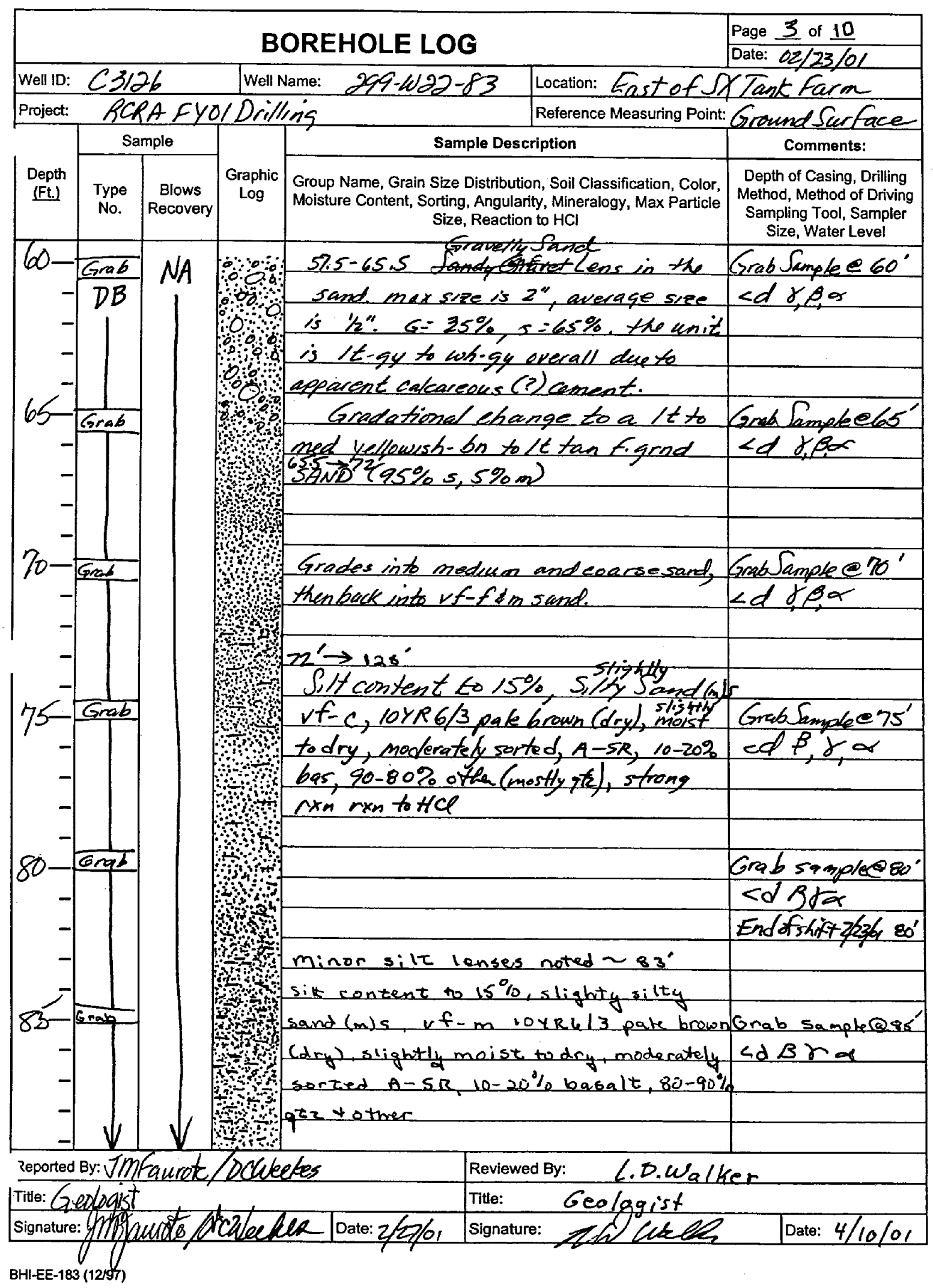




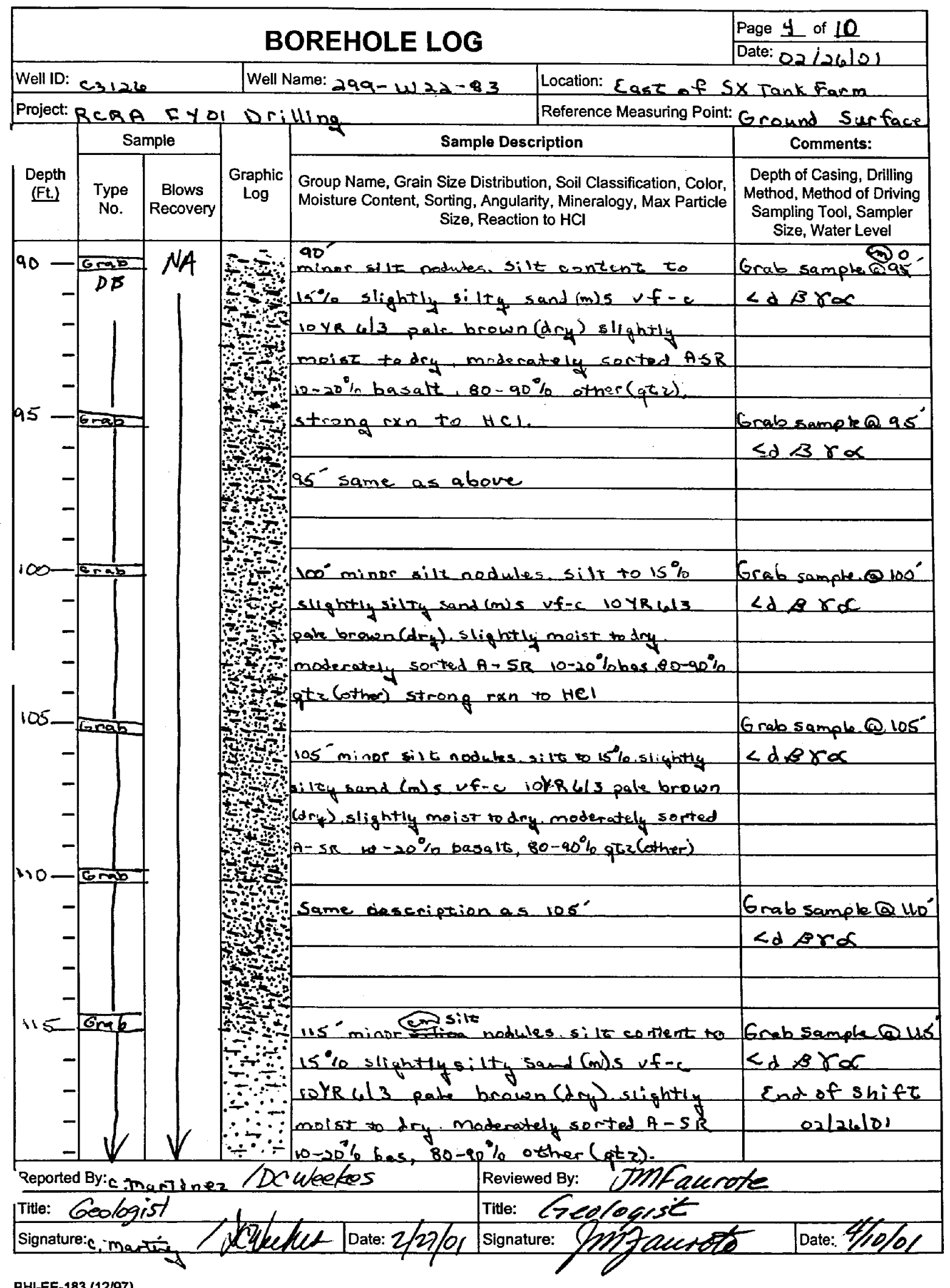




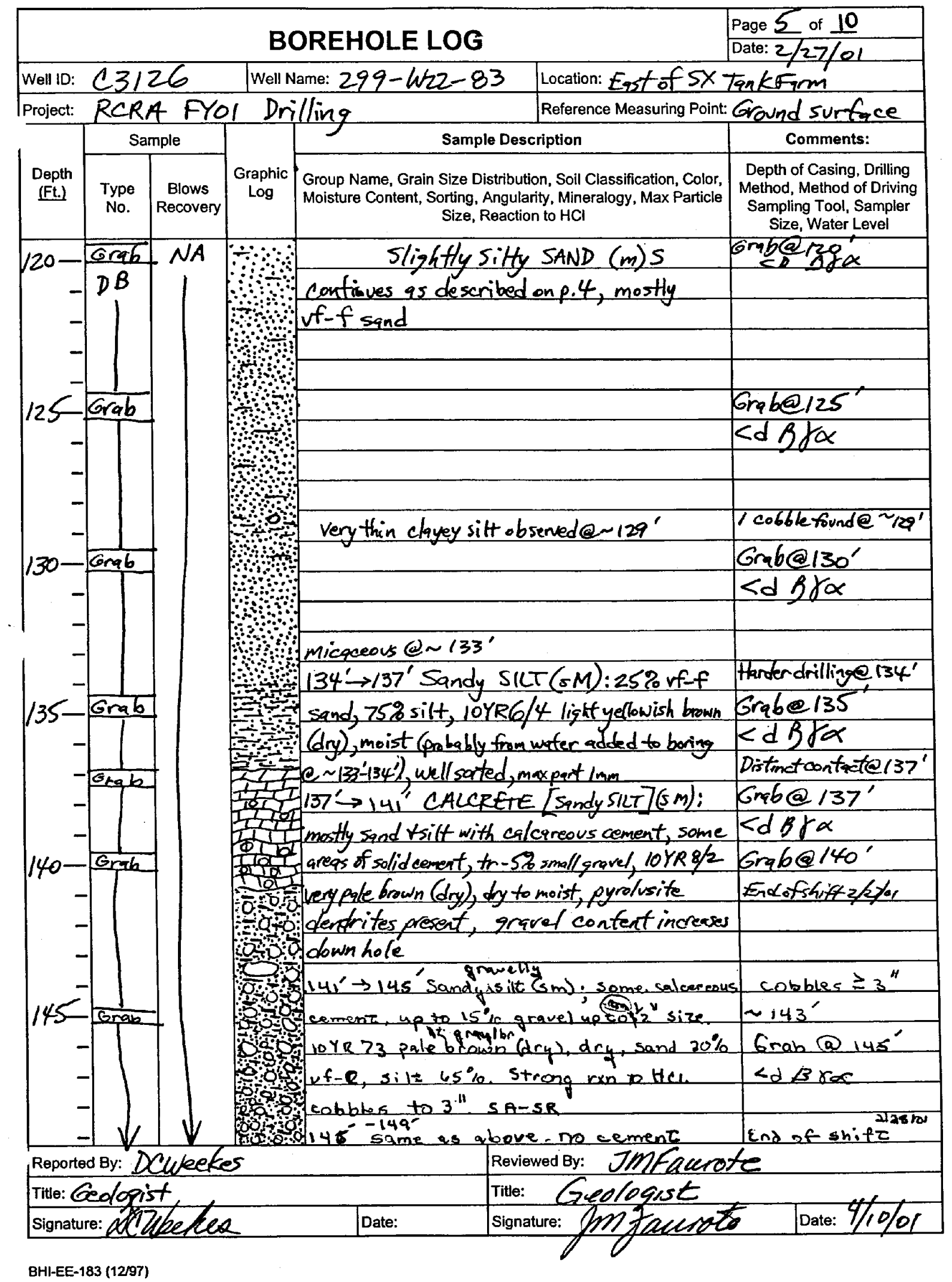




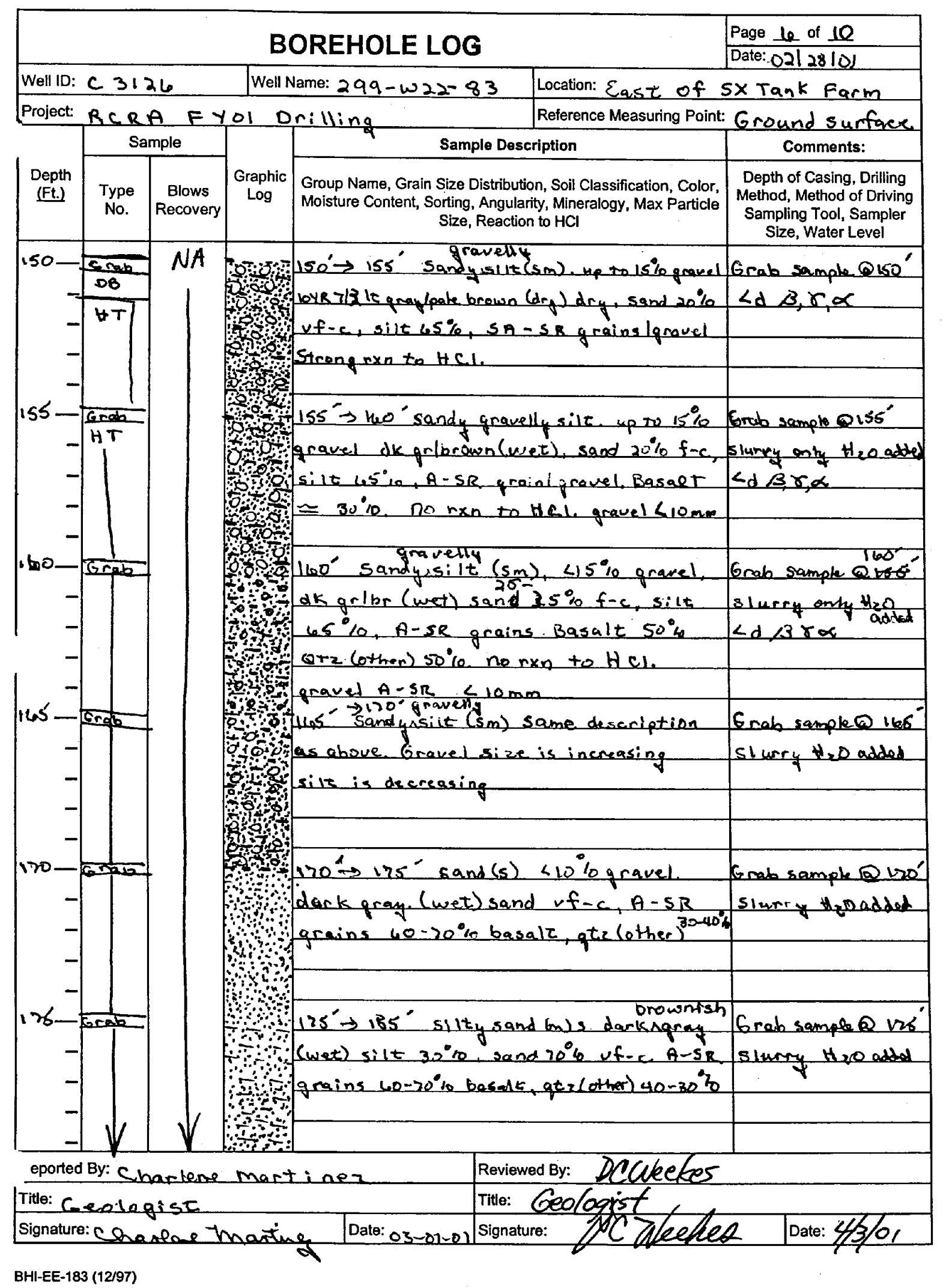




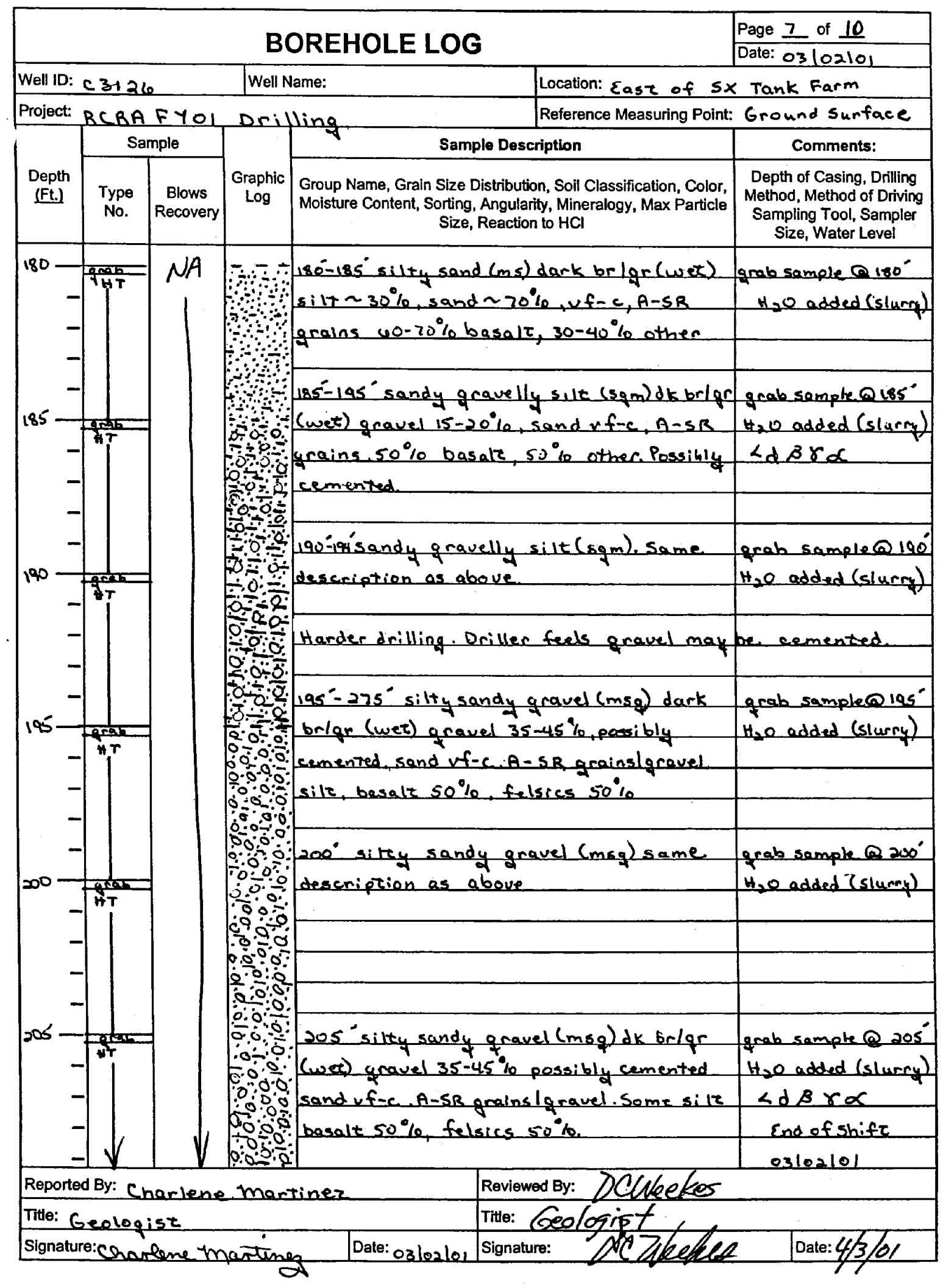

BHI-EE-183 (12/97) 


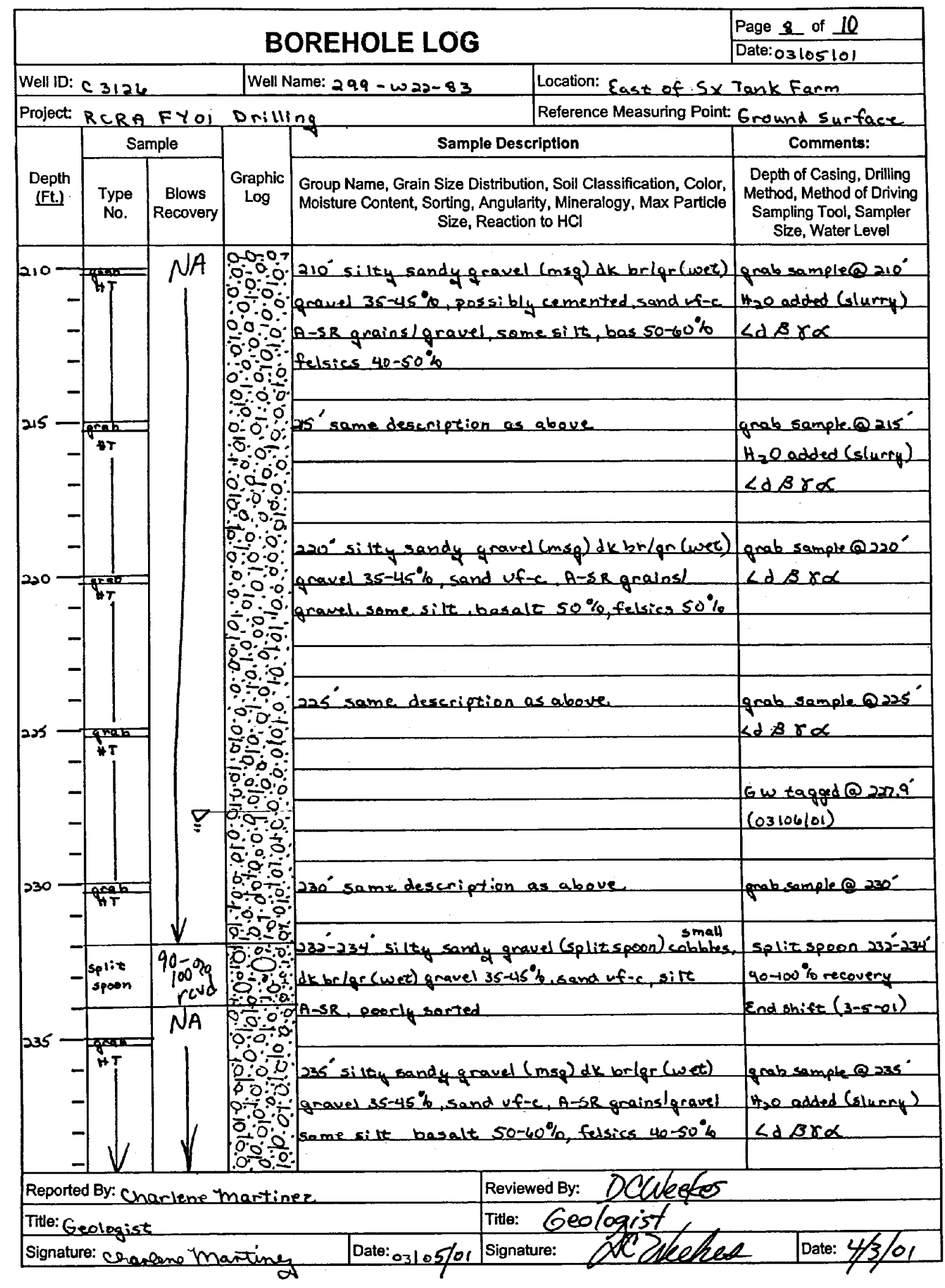

BHI-EE-183 (12/97) 


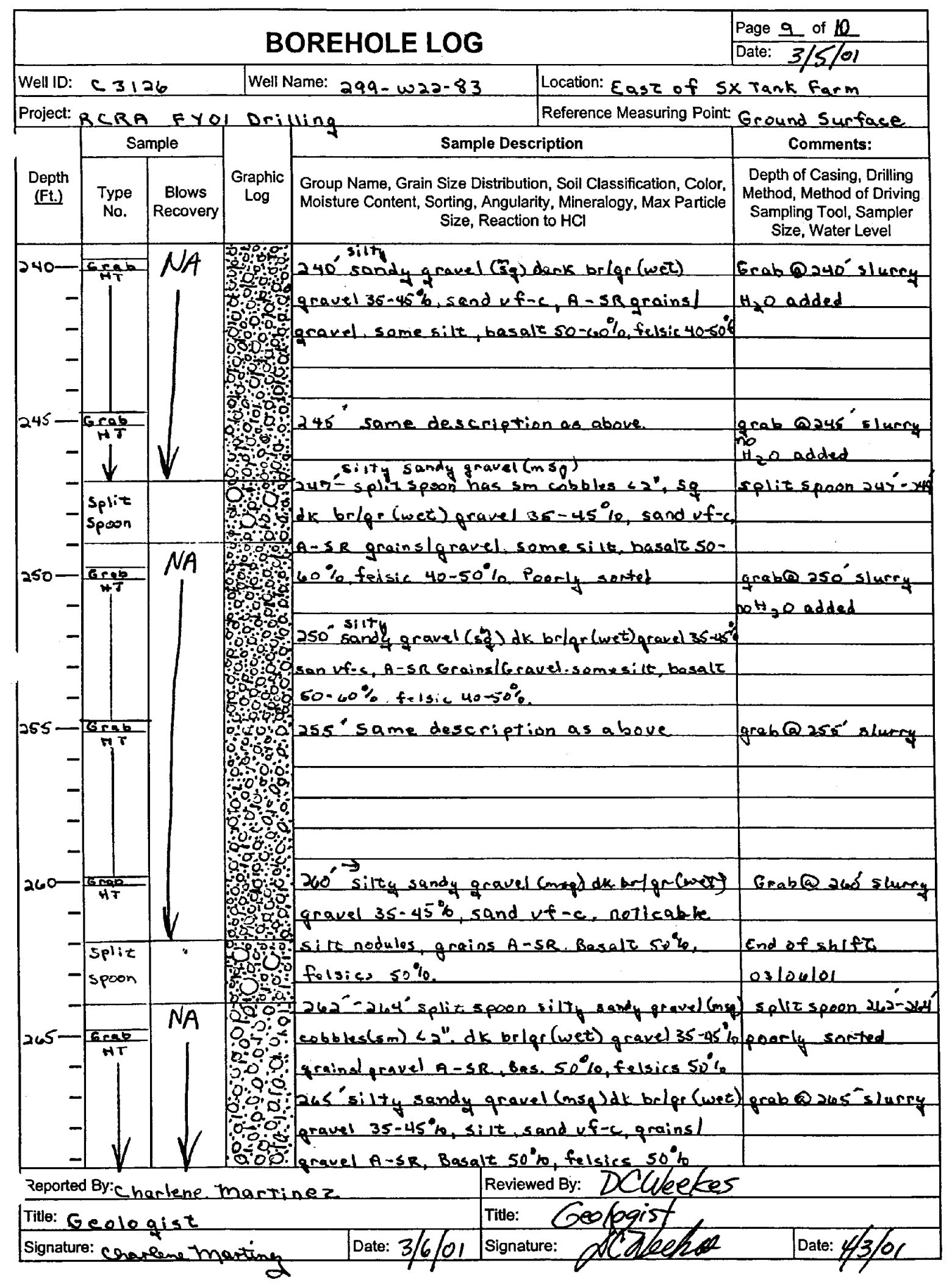

BHI-EE-183 (12/97) 


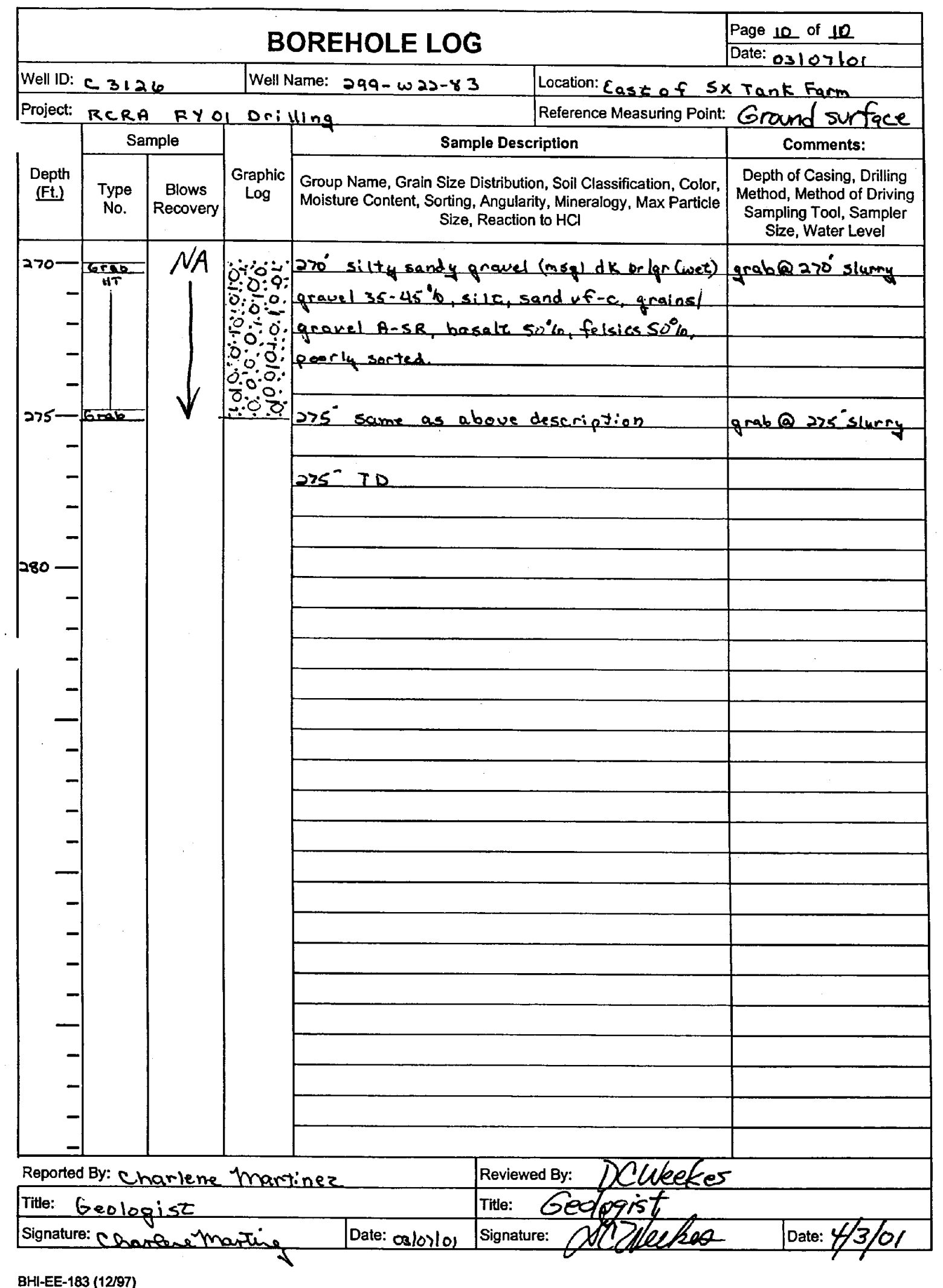




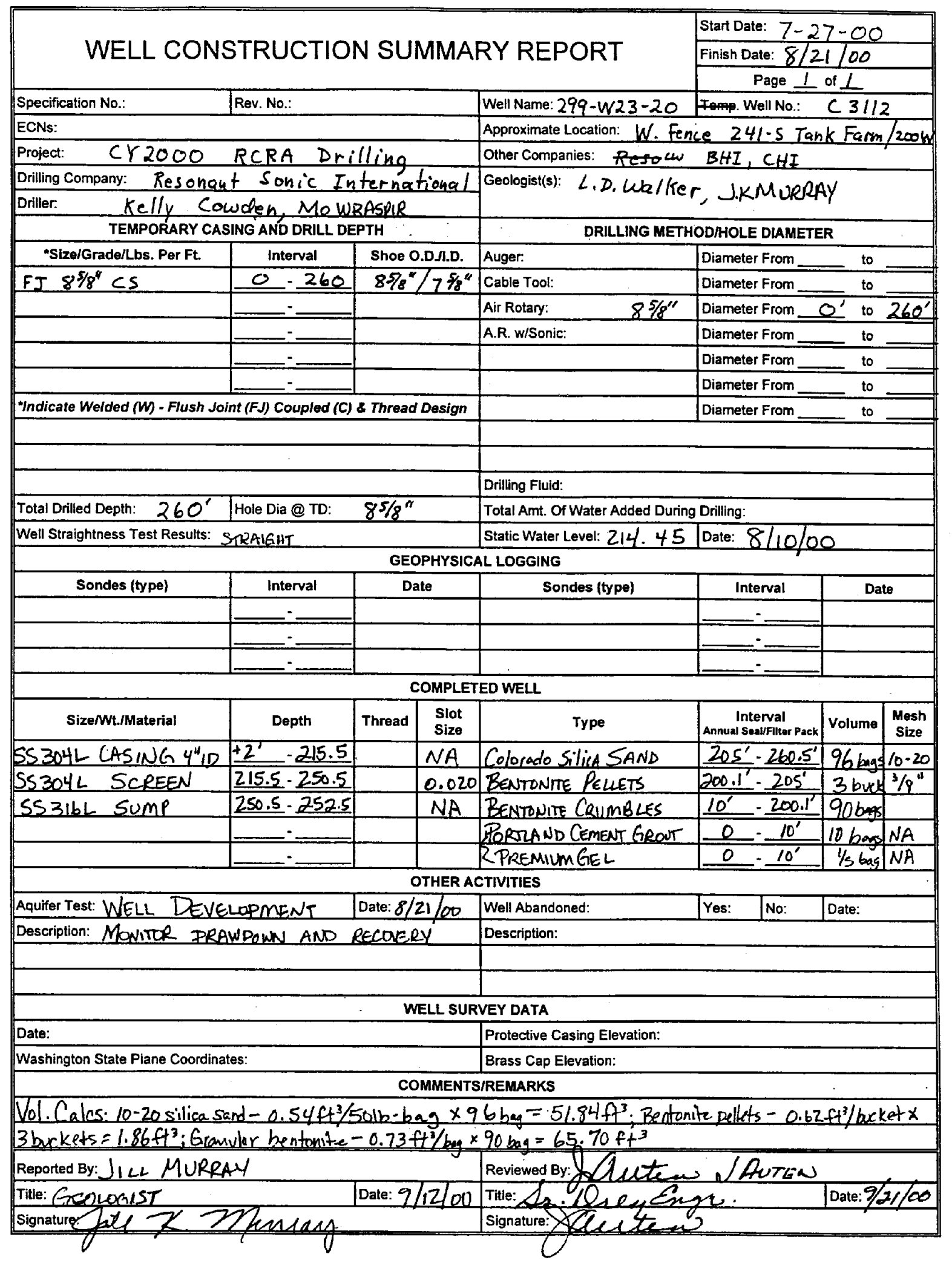

BHI-EE-181 (12/97) 


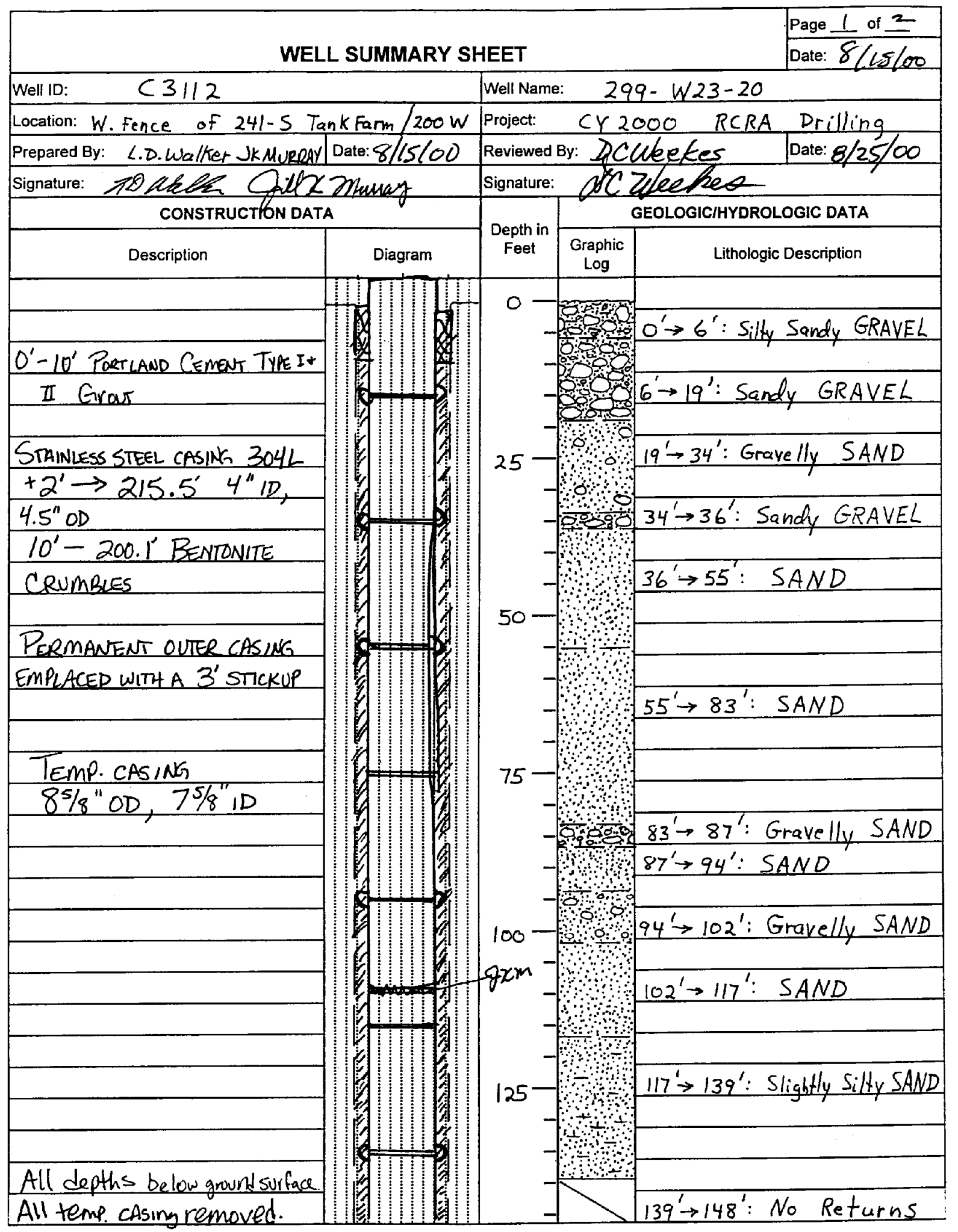

BHI-EE-189 (12/97) 




BHI-EE-189 (12/97) 


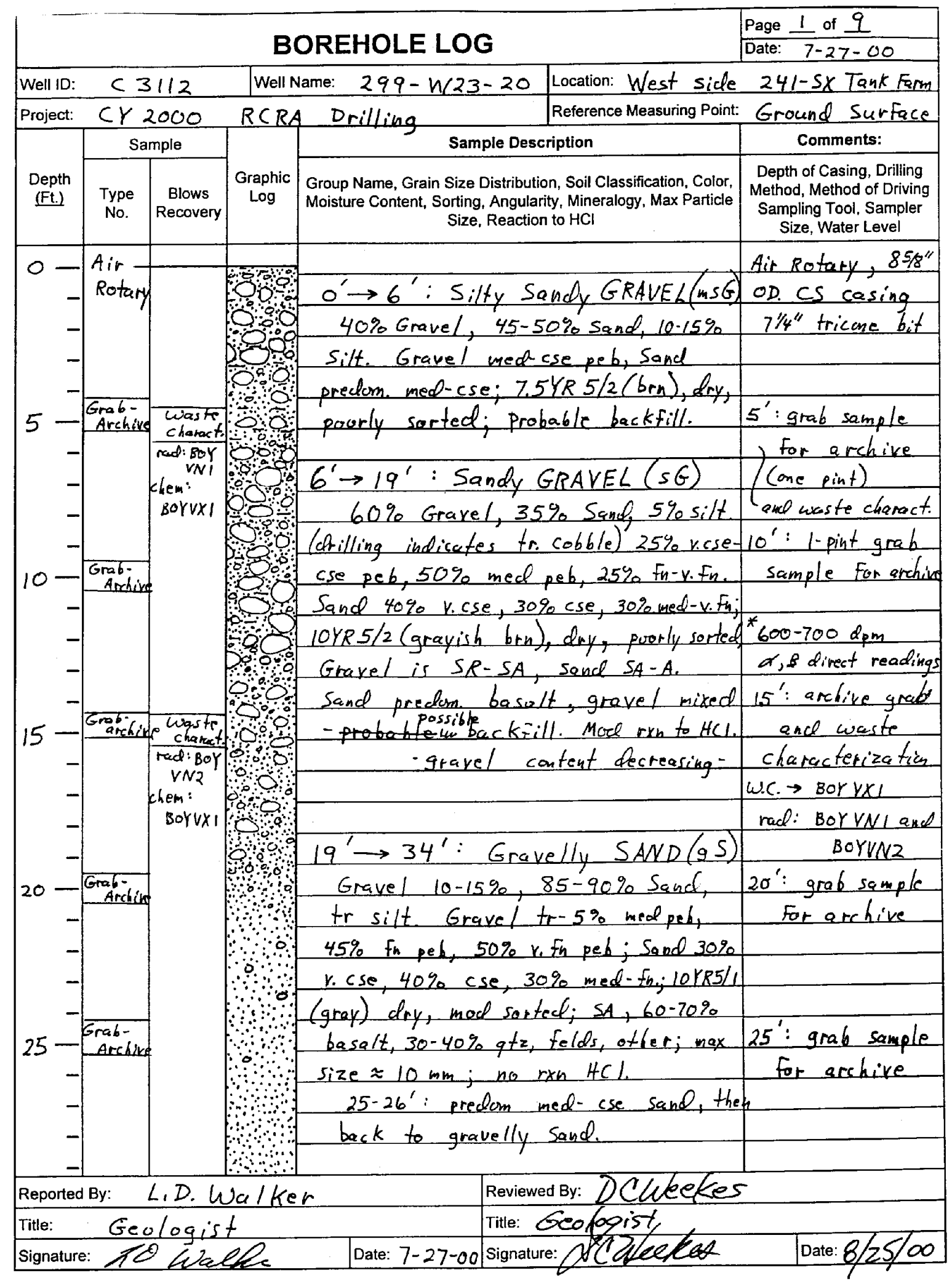

BHI-EE-183 (12/97) 


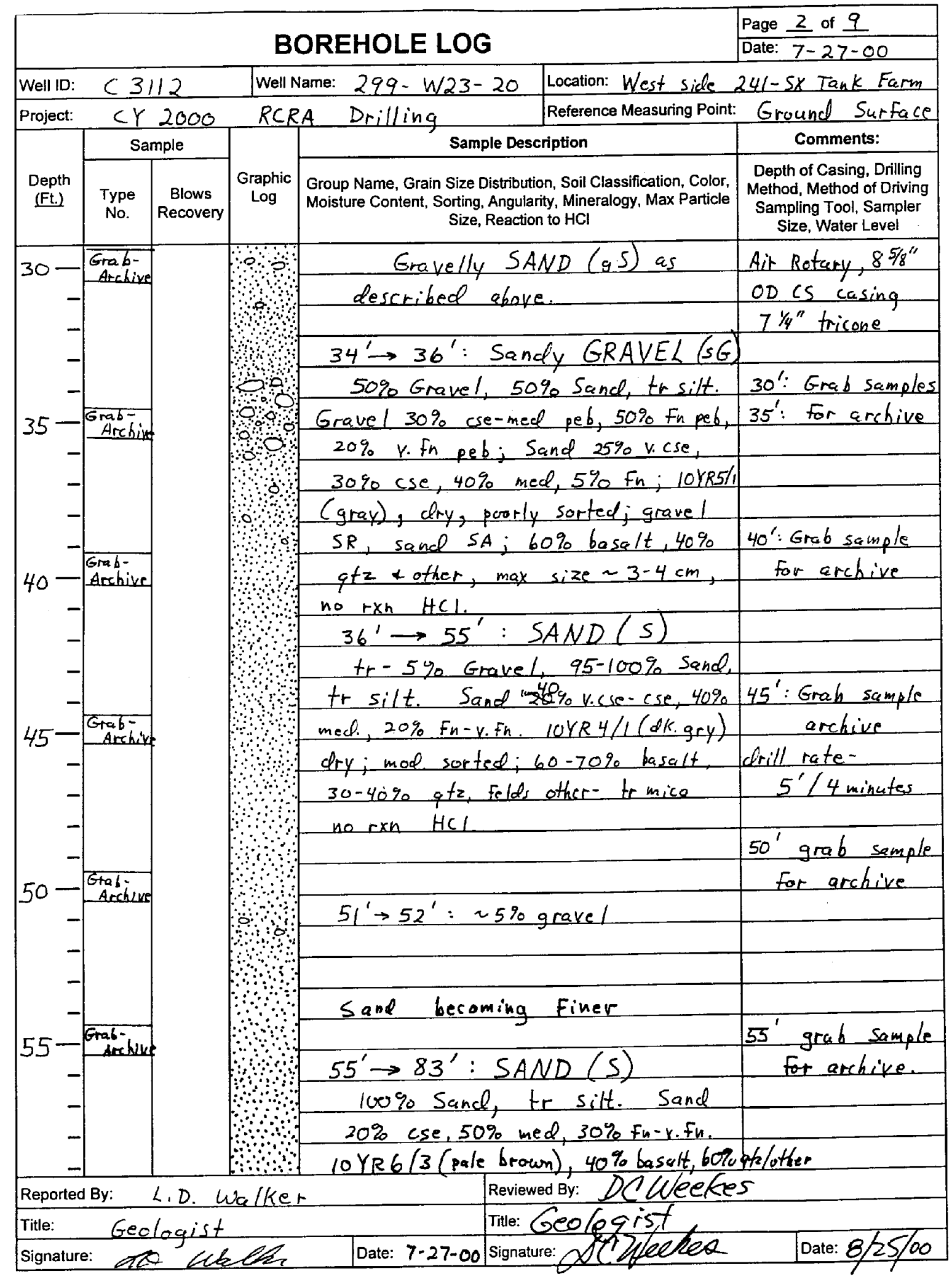

BHI-EE-183 (12/97) 


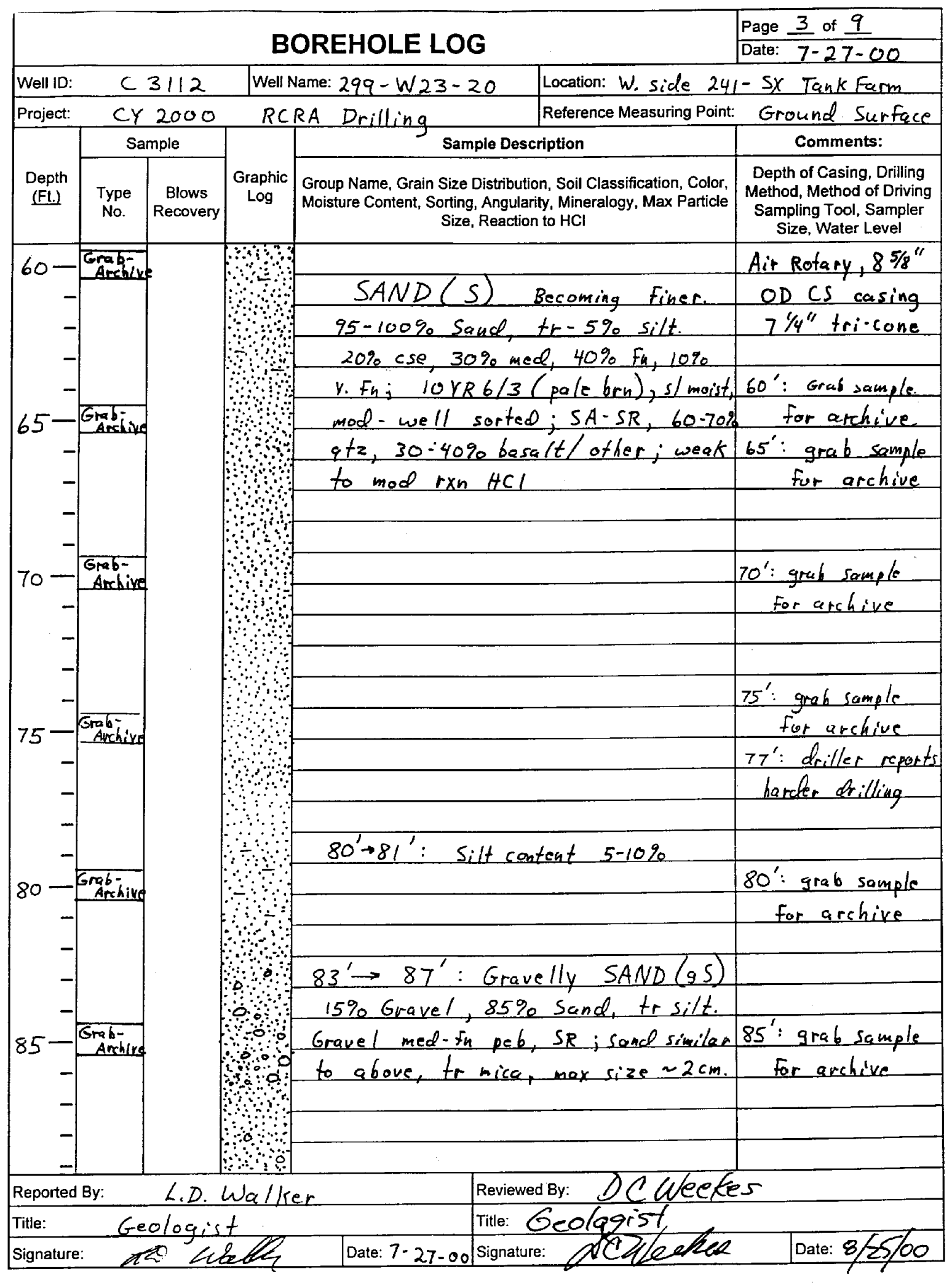

BHI-EE-183 (12/97) 


\begin{tabular}{|c|c|c|c|c|c|c|}
\hline \multirow{2}{*}{\multicolumn{6}{|c|}{ BOREHOLE LOG }} & \multirow{2}{*}{\begin{tabular}{|l|} 
Page 4 of 9 \\
Date: \\
$7-27-00$
\end{tabular}} \\
\hline & & & & & & \\
\hline Well ID: & \multicolumn{2}{|c|}{$C 3112$} & \multicolumn{2}{|c|}{ Well Name: $299-W 23-20$} & \multicolumn{2}{|c|}{ Location: W. side 241-SX Tank farm/2ader } \\
\hline Project: & \multicolumn{2}{|c|}{ CY 2000} & $R C$ & $R A$ Drilling & \multicolumn{2}{|c|}{ Reference Measuring Point: Ground Surface } \\
\hline \multirow[b]{2}{*}{$\begin{array}{c}\text { Depth } \\
\text { (Ft.) }\end{array}$} & \multicolumn{2}{|c|}{ Sample } & \multirow[b]{2}{*}{$\begin{array}{c}\text { Graphic } \\
\text { Log }\end{array}$} & \multicolumn{2}{|c|}{ Sample Description } & \multirow{2}{*}{\begin{tabular}{|c|} 
Comments: \\
Depth of Casing, Drilling \\
Method, Method of Driving \\
Sampling Tool, Sampler \\
Size, Water Level \\
\end{tabular}} \\
\hline & $\begin{array}{l}\text { Type } \\
\text { No. }\end{array}$ & $\begin{array}{c}\text { Blows } \\
\text { Recovery }\end{array}$ & & \multicolumn{2}{|c|}{$\begin{array}{l}\text { Group Name, Grain Size Distribution, Soil Classification, Color, } \\
\text { Moisture Content, Sorting, Angularity, Mineralogy, Max Particle } \\
\text { Size, Reaction to HCl }\end{array}$} & \\
\hline \multirow{5}{*}{$\begin{array}{rr}90 & - \\
& - \\
& - \\
& -\end{array}$} & \multirow{5}{*}{$\begin{array}{l}\text { Grab- } \\
\text { Archive }\end{array}$} & & \multirow{3}{*}{ 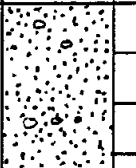 } & \multicolumn{2}{|c|}{$87^{\prime} \rightarrow 94^{\prime}:$ SAND $(S) ; 58$ Gravel } & Ait Rotary, $85 / 8^{\prime \prime}$ \\
\hline & & & & \multicolumn{2}{|c|}{$95 \%$ Sand, to silt. Gravel $10 \%$} & $O D C S$ casing \\
\hline & & & & \multicolumn{2}{|c|}{ Fn peh, $90 \%$ r. Fn peh. Sanch 50\% r.cse } & \\
\hline & & & \multirow{3}{*}{$\begin{array}{l}0 \\
0 \\
0 \\
0 \\
0 \\
0 \\
0 \\
0\end{array}$} & \multirow{2}{*}{\multicolumn{2}{|c|}{$\begin{array}{l}\text { to cse, } 30 \% \text { med, } 20 \% \text { Fu-r. Fu } \\
94^{\prime} \rightarrow 102^{\prime}: \text { Gravelly sand }(95)\end{array}$}} & \multirow{2}{*}{$\begin{array}{l}90 ' \text { grah sample } \\
\text { for archive }\end{array}$} \\
\hline & & & & & & \\
\hline \multirow{5}{*}{$95-6$} & \multirow{4}{*}{ Aurhive } & & & \multicolumn{2}{|c|}{$15 \%$ gravel, $80 \%$ Sand, $5 \%$ silt } & \\
\hline & & & \multirow{3}{*}{ 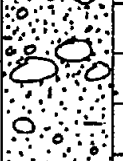 } & \multicolumn{2}{|l|}{$97^{\prime}$ : gravel } & $95^{\prime}$ grab sample \\
\hline & & & & 2590 Gravel & $5 \%$ Sand, trsilt & For archive \\
\hline & & & & & & \\
\hline & Akhing & & ب. & & & $100^{\prime}$ grab sample \\
\hline & & & 0 & $102^{\prime} \rightarrow 117^{\prime}: S$ & $V D(S) ; \operatorname{tr} .5 \%$ & \\
\hline- & & & 0 & Grave $1,95-100$ & Sand, tr silt. & \\
\hline- & & & $\therefore$ & Gravel is med-in & 6 ; Sand $20 \%$ V.cse. & $105^{\prime}$ : grab sample \\
\hline $105-6$ & Srab: & & 0 & $\mathrm{cse}, 50 \%$ med, $30 \%$ & $n-V . F_{n} .10 Y R 5 / 2$ & fur archive. \\
\hline & & & $\because$ & (gryish bre) sl m & st; mod sorted; & \\
\hline- & & & $\therefore$ & Sand $S A-S R ; 7$ & $\%$ gts, Felds, 25\% & \\
\hline & & & 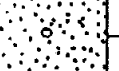 & basalt/other, & eak $\mathrm{rxn} \mathrm{HCl}$ & ' \\
\hline $110-5^{6}$ & rabi & & $\therefore$ & & & $\begin{array}{l}110 \text { grab sample } \\
\text { for archive }\end{array}$ \\
\hline & & & 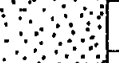 & grayel decreasin & Sand size of crease & \\
\hline & & & $\because$ & & & \\
\hline- & & & 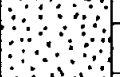 & & & $115^{\prime}$ grab sample. \\
\hline $115-6$ & $\begin{array}{l}\text { Prab: } \\
\text { Archive }\end{array}$ & & & & & for archive \\
\hline & & & & & & \\
\hline & & & $\begin{array}{lll}0 \\
\ddots\end{array}$ & & & \\
\hline & & & $\because 4$ & & & \\
\hline Reported $\mathrm{E}$ & 3y: & D. Wa & alker & & ed By: DCleckes & \\
\hline Title: & Geols & ogist & & & Geologist & \\
\hline Signature: & 10 & stet & $\mathbb{2}$ & \begin{tabular}{|l|l|l|} 
Date: $7-27-00$ & Sig \\
\end{tabular} & ure: Zleeres & Date: $8 / 25 / 00$ \\
\hline
\end{tabular}

BHI-EE-183 (12/97) 




BHI-EE-183 (12/97) 


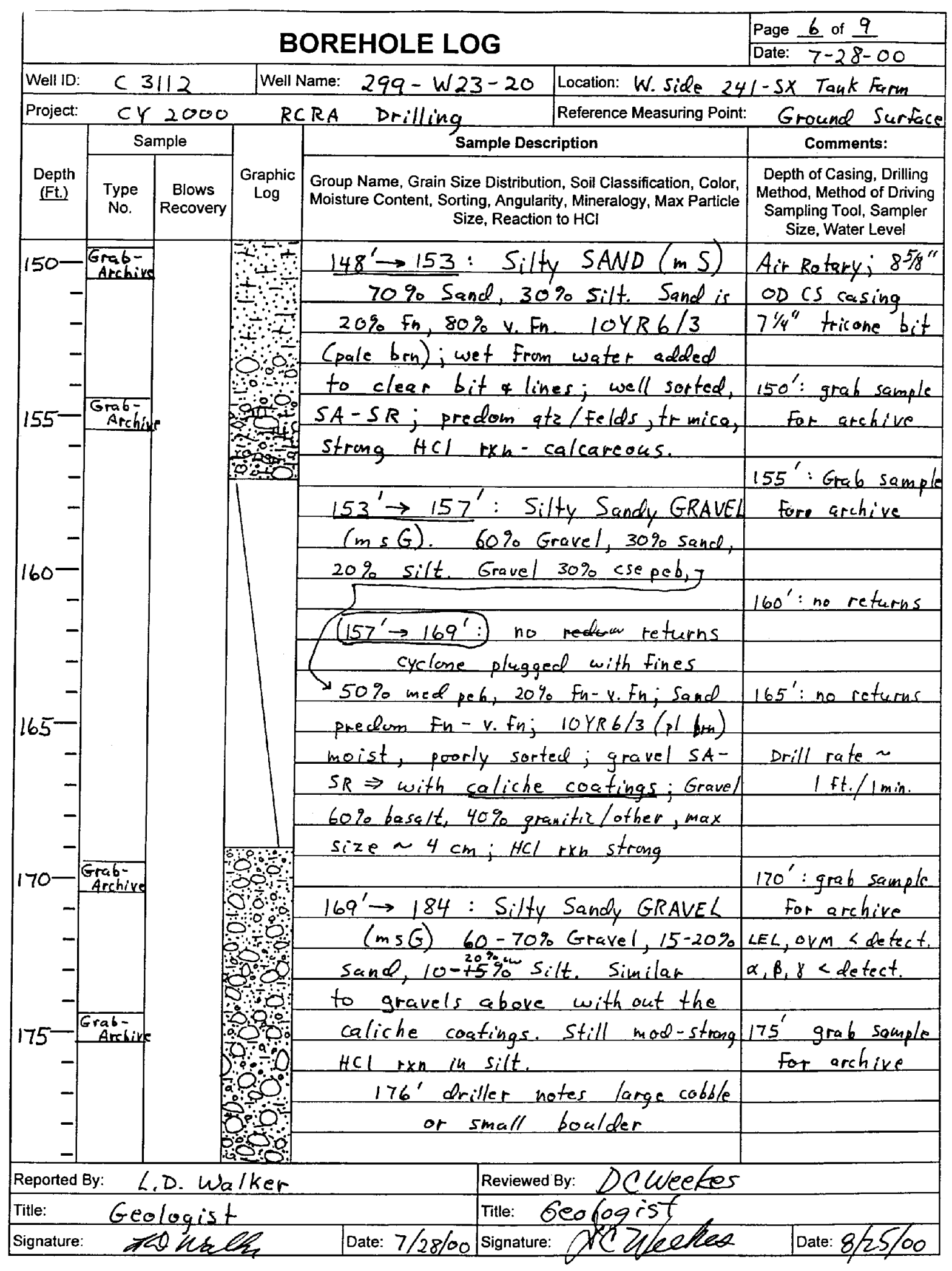

BHI-EE-183 (12/97) 


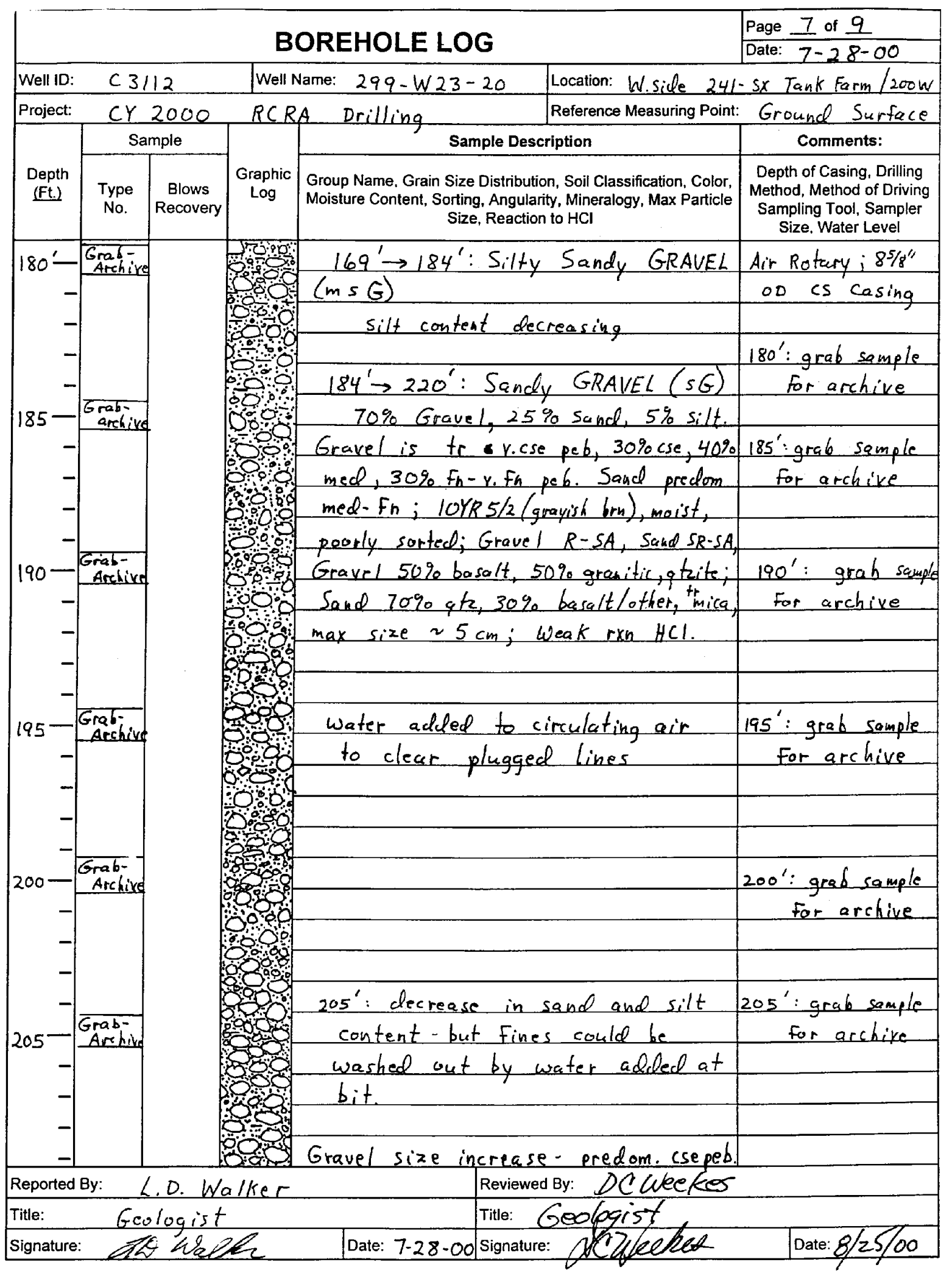

BHI-EE-183 (12/97) 


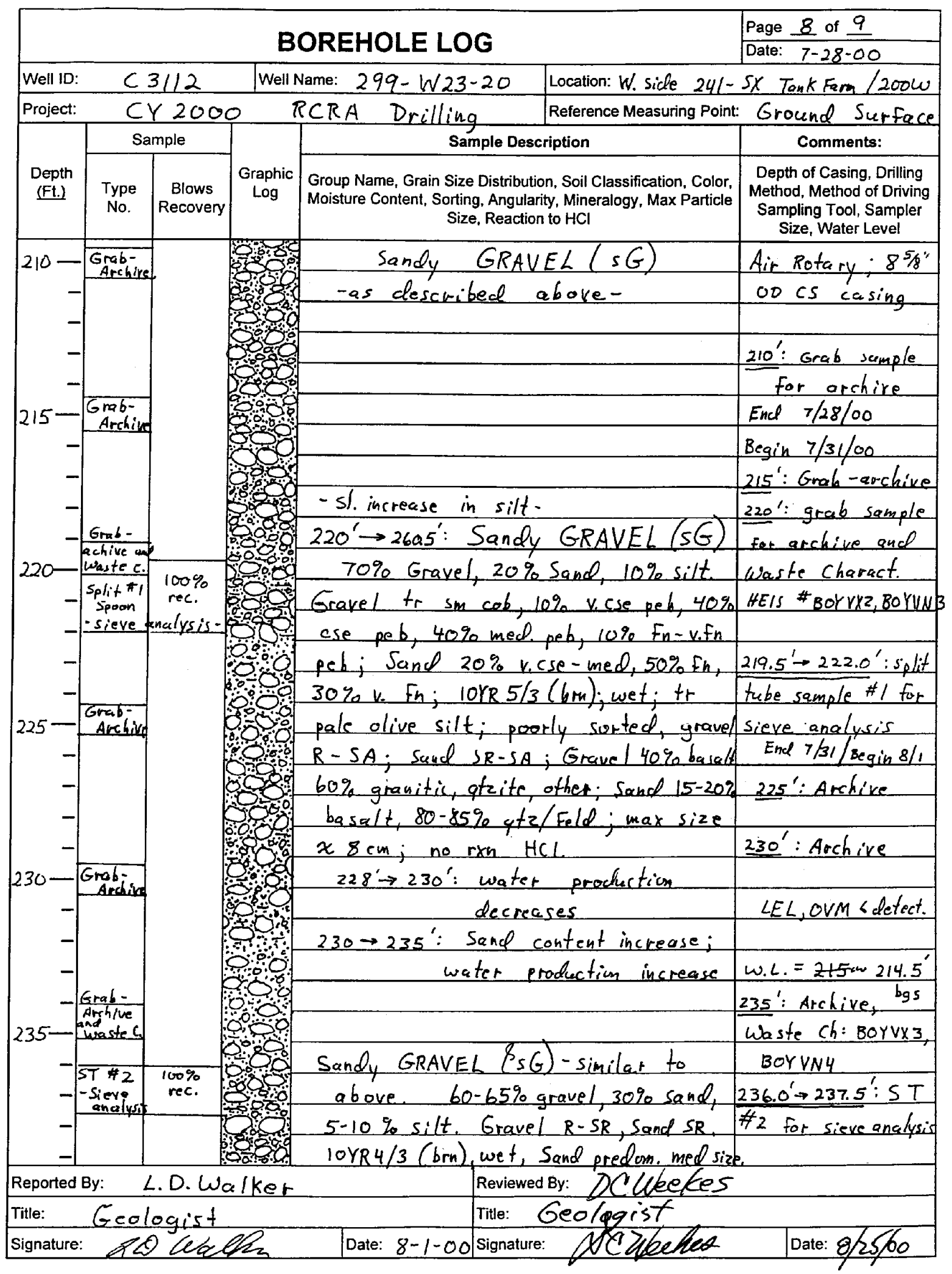

BHI-EE-183 (12/97) 


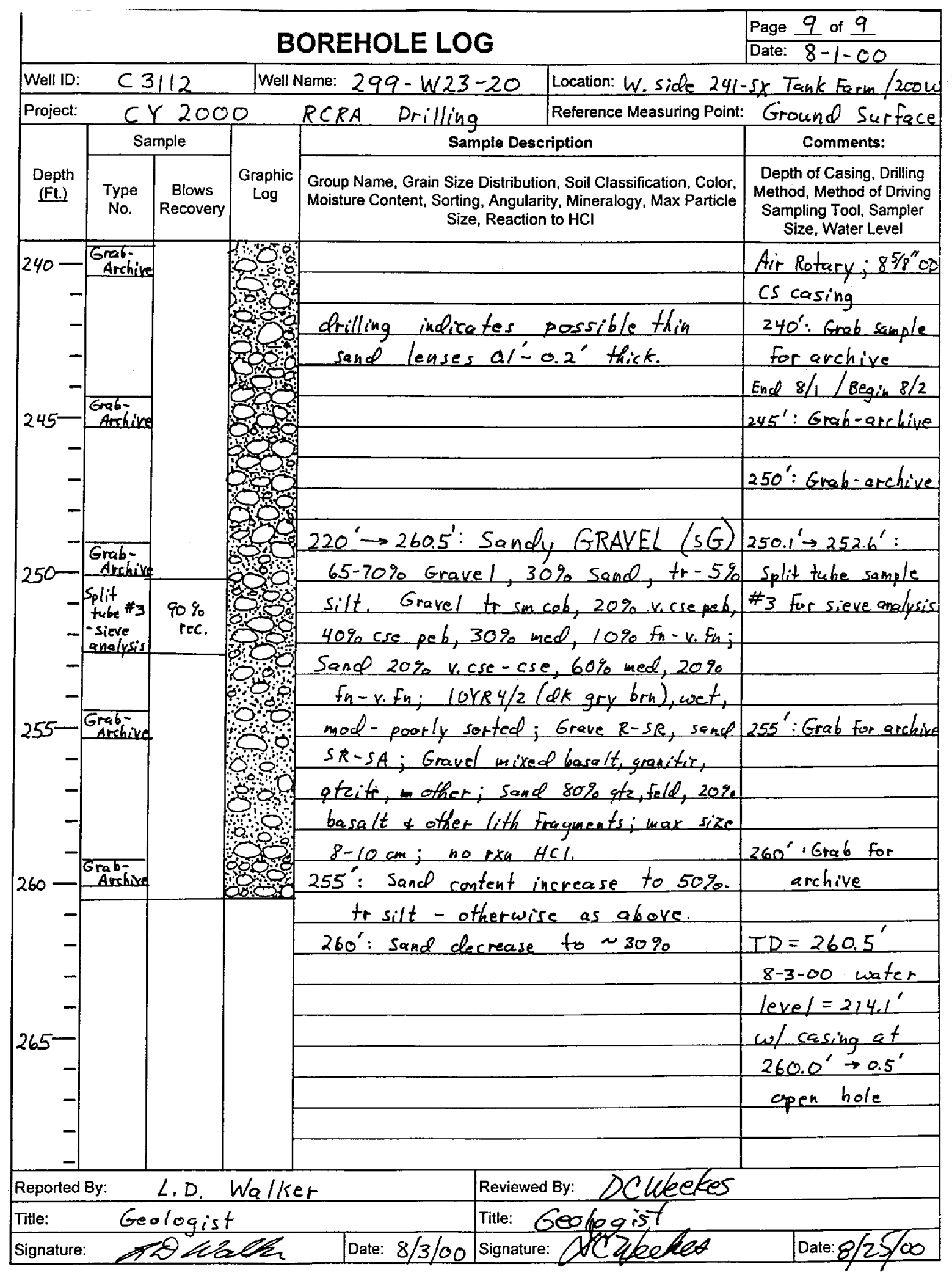

BHI-EE-183 (12/97) 


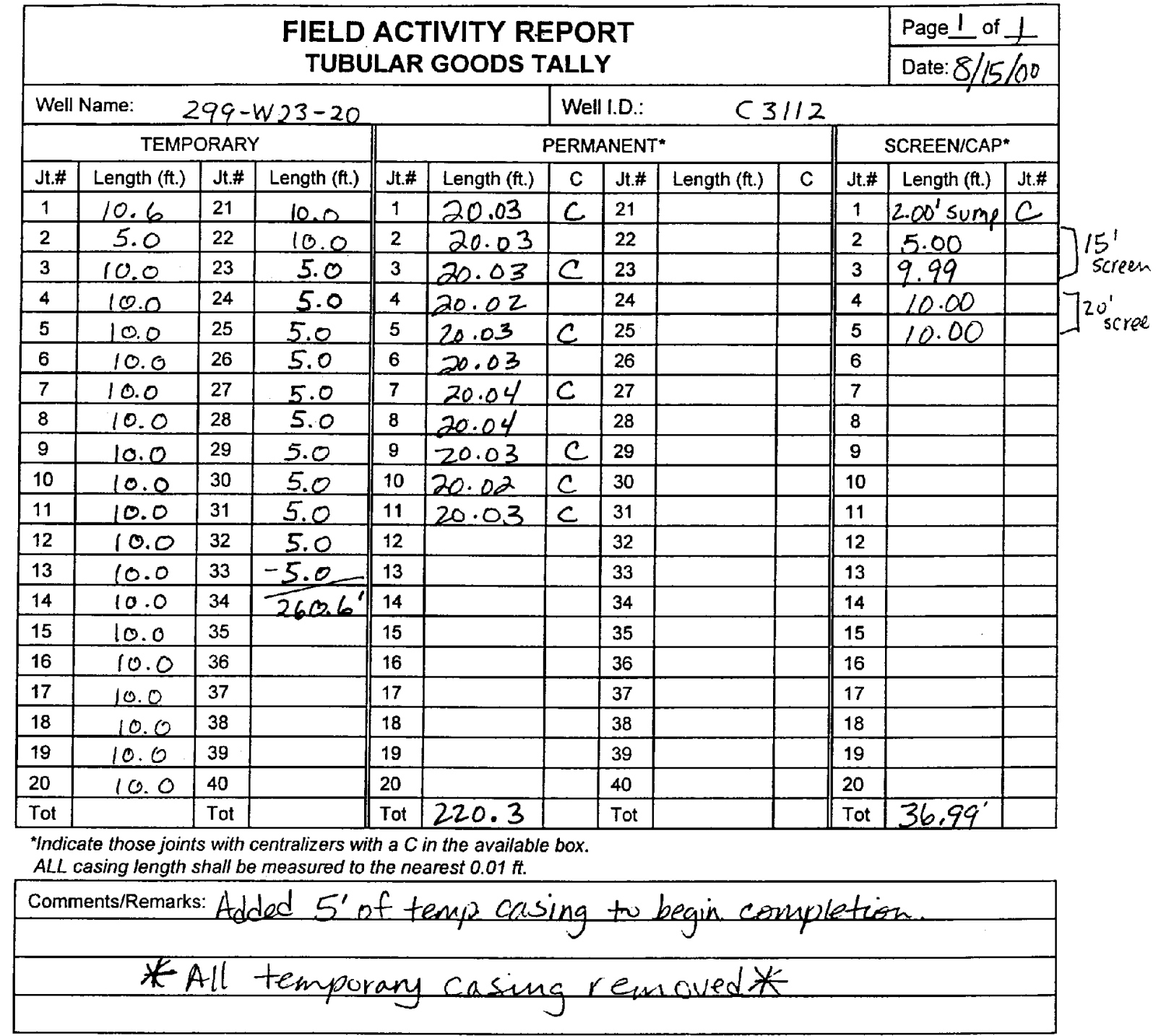

\section{Oxm-ok-}

Temporary: 0.D.I.D. $85 / 8^{\prime \prime} / 758^{\prime \prime}$ Permanent: O.D.I.D. $4.5^{\prime \prime} / 4^{\prime \prime} 4.5^{\prime \prime} / 4$ screen: O.D.II.D. 4.5"1/4" PERMANENT CASING * SCREEN ARE SS $304 \mathrm{~L}$. SCREEN IS. OZO SLOT. TALPIPE is SS316L w/ 4" $I D+4.5^{\prime \prime} O D$. There is the extra joint WNH A CENTRALIZER BECAUSE THAT WAS WHAT WAS AVALABIE AT TIME OF INSTAKLNMION.

STAINLESS stickup of $4.8^{\prime}$ cut to $2.0^{\prime}$

Permanent ovter casing $6.0^{\prime}$ piece emplaced with a $3.0^{\prime}$ stickup.

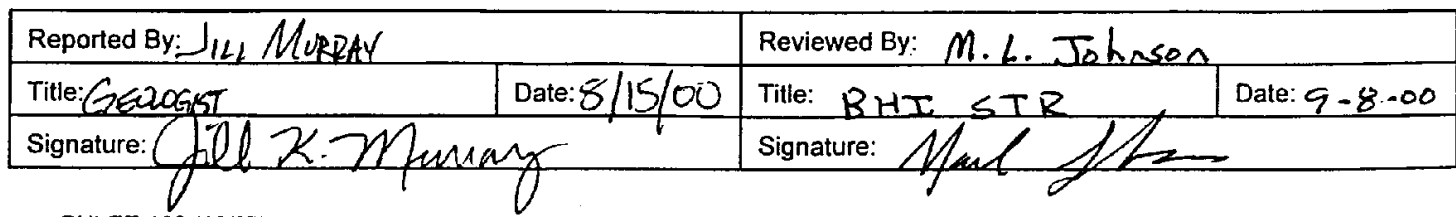

BHI-EE-182 (12/97) 


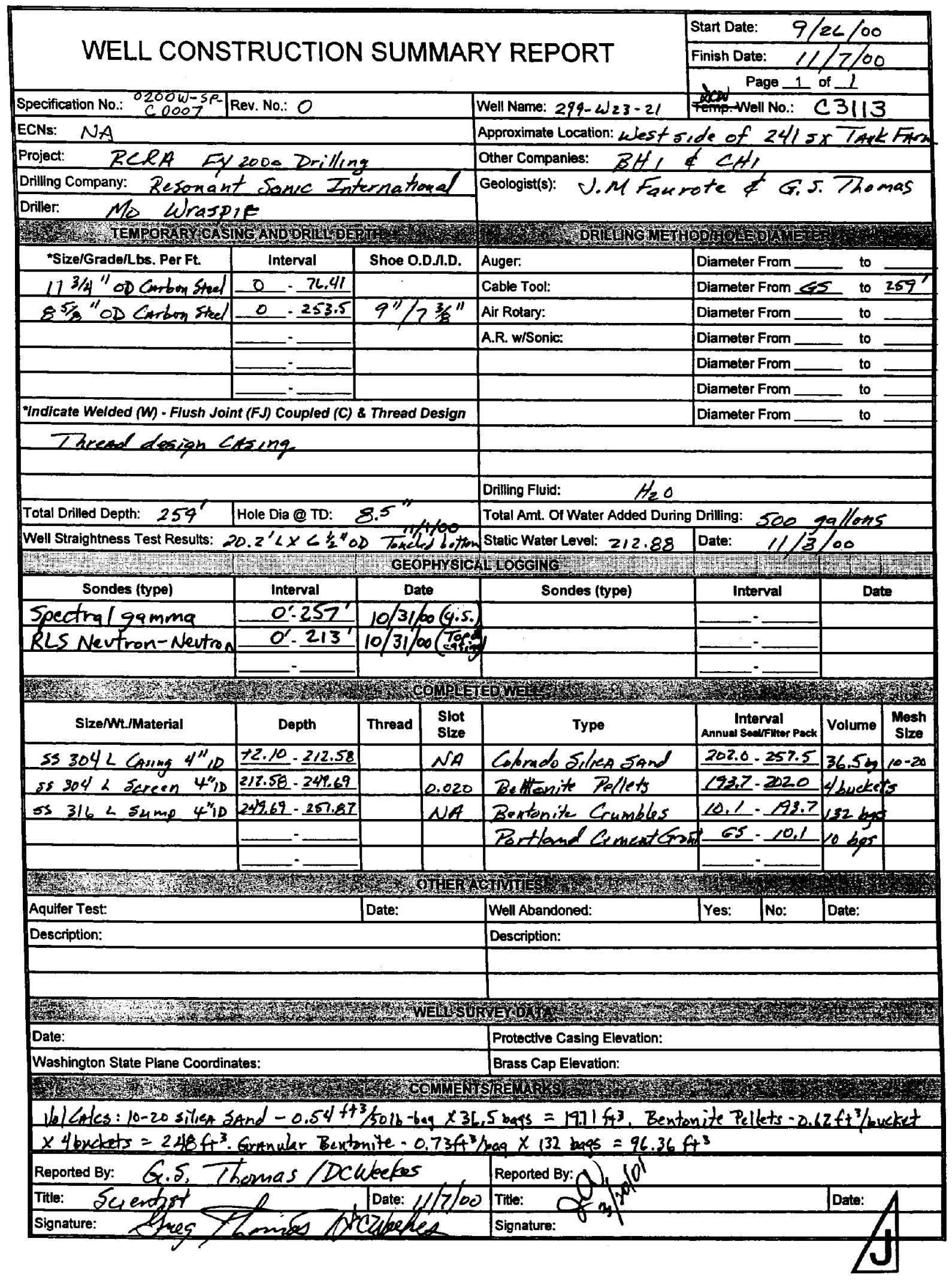




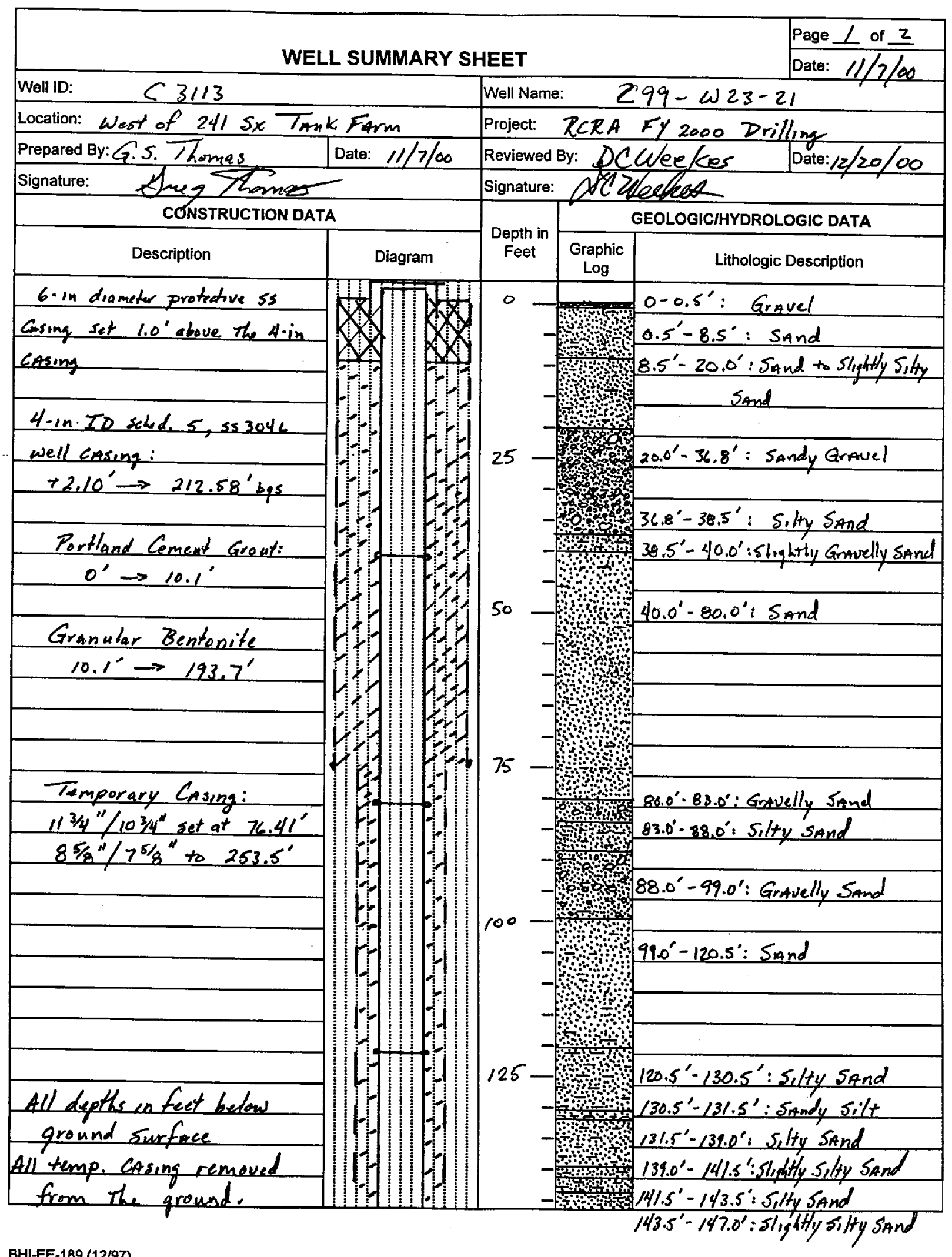




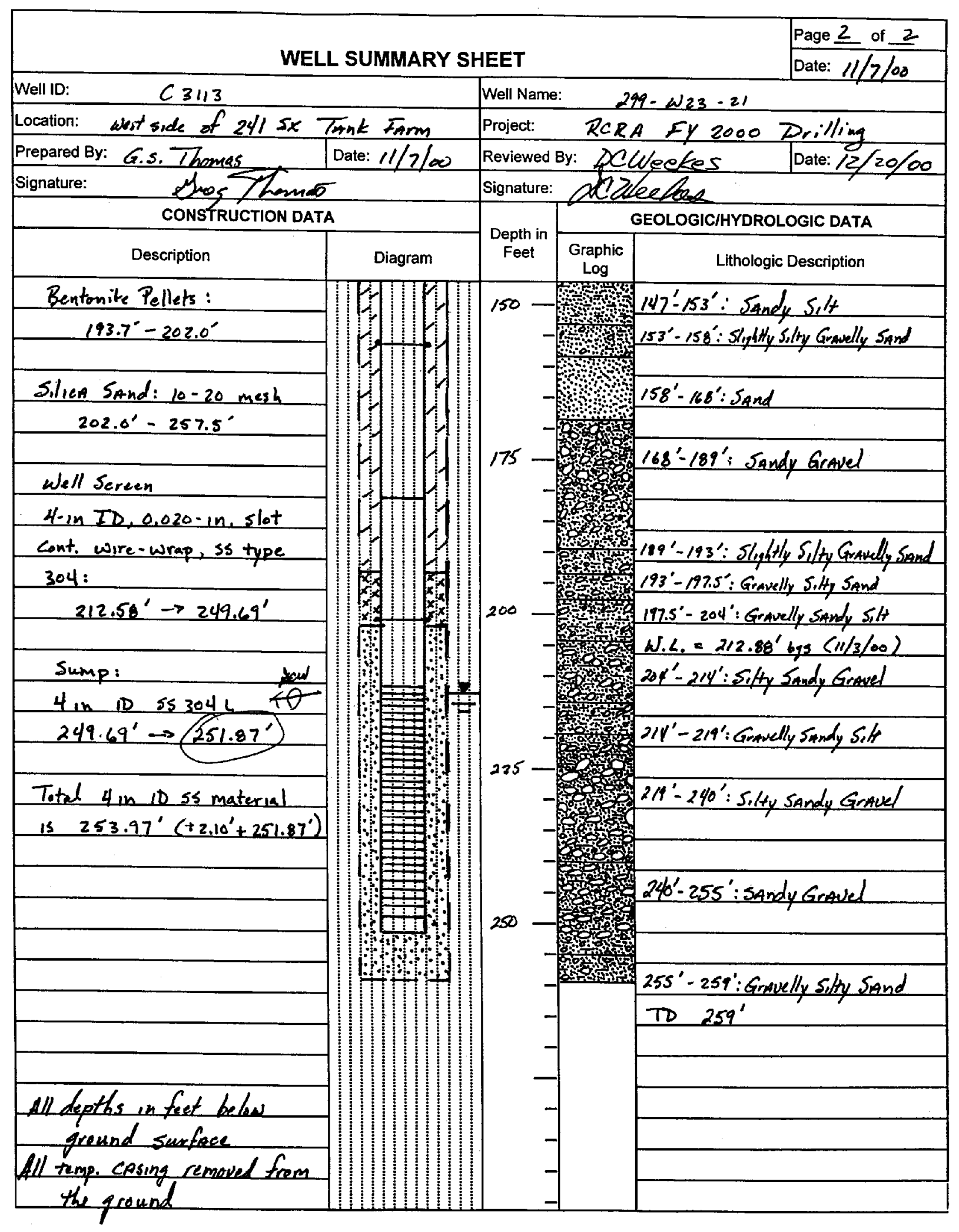

BHI-EE-189 (12/97) 


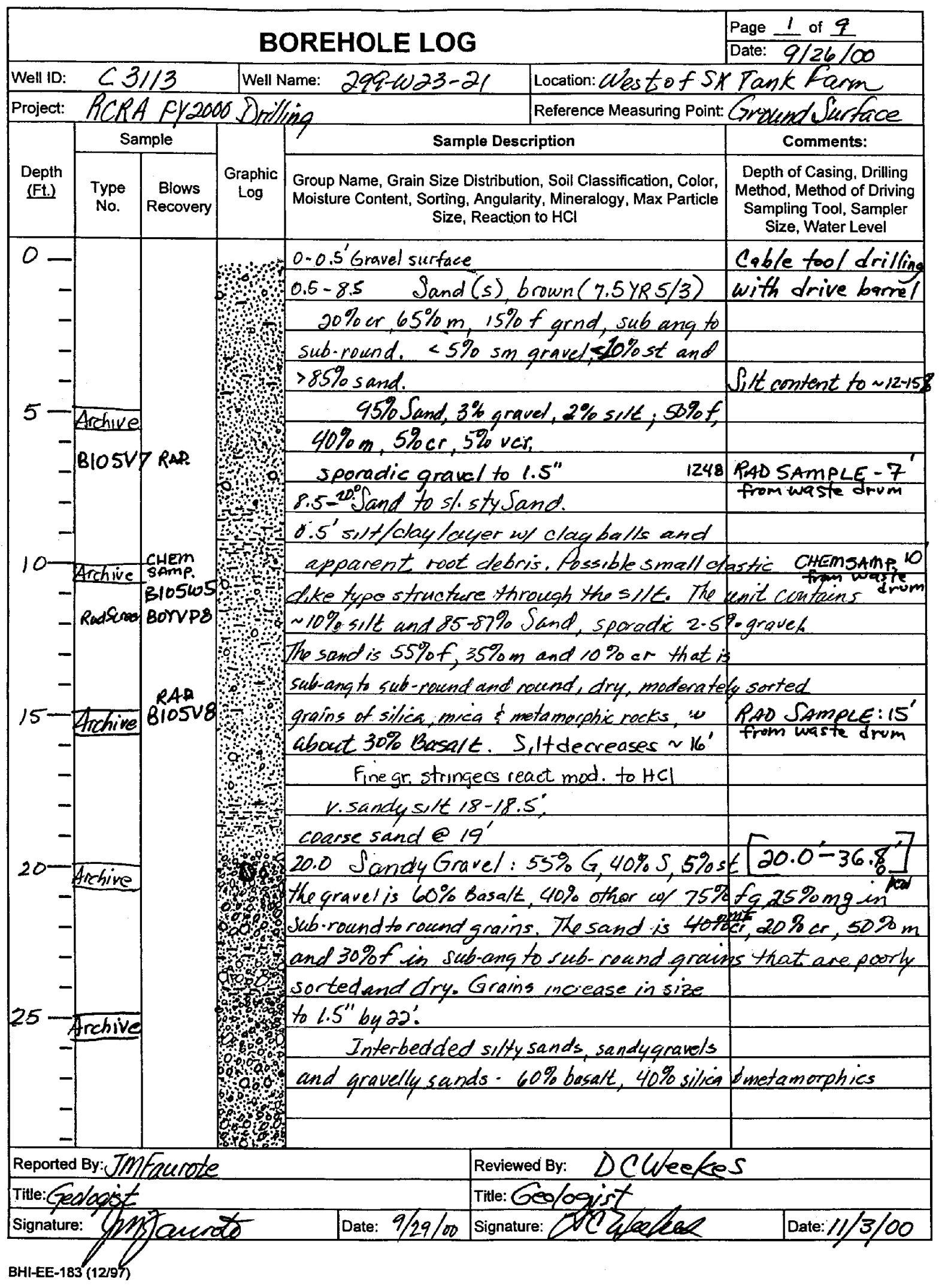




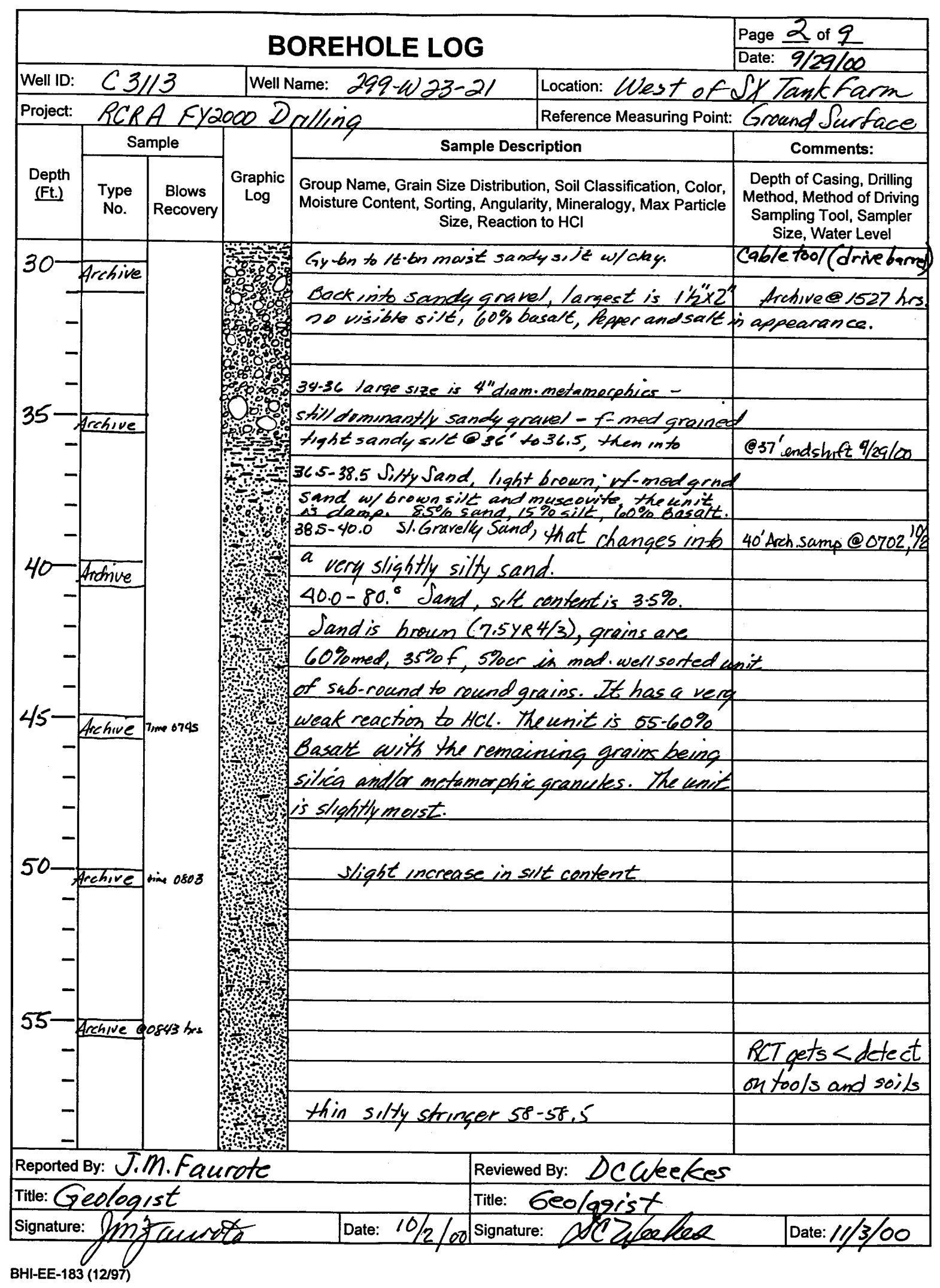




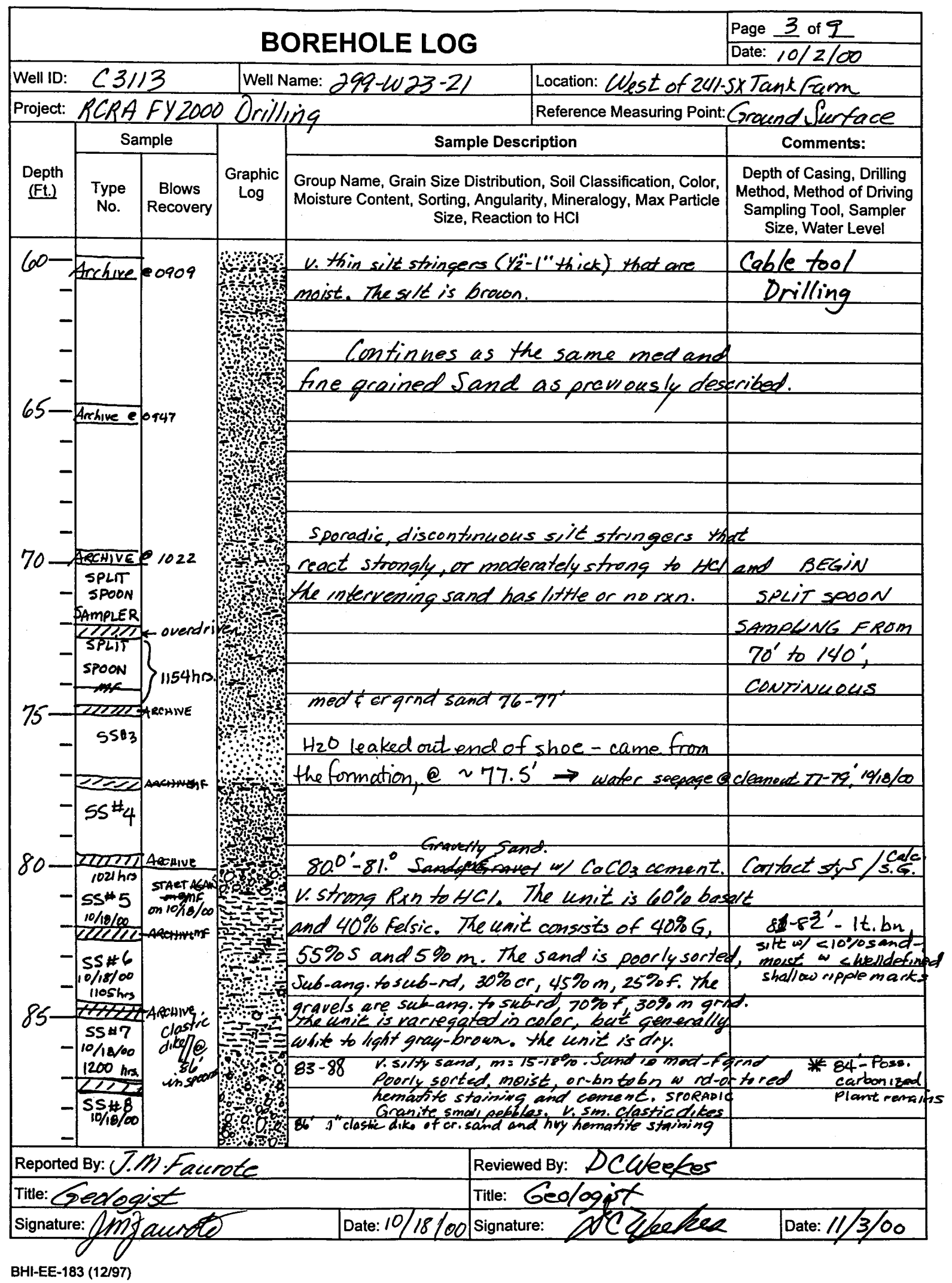




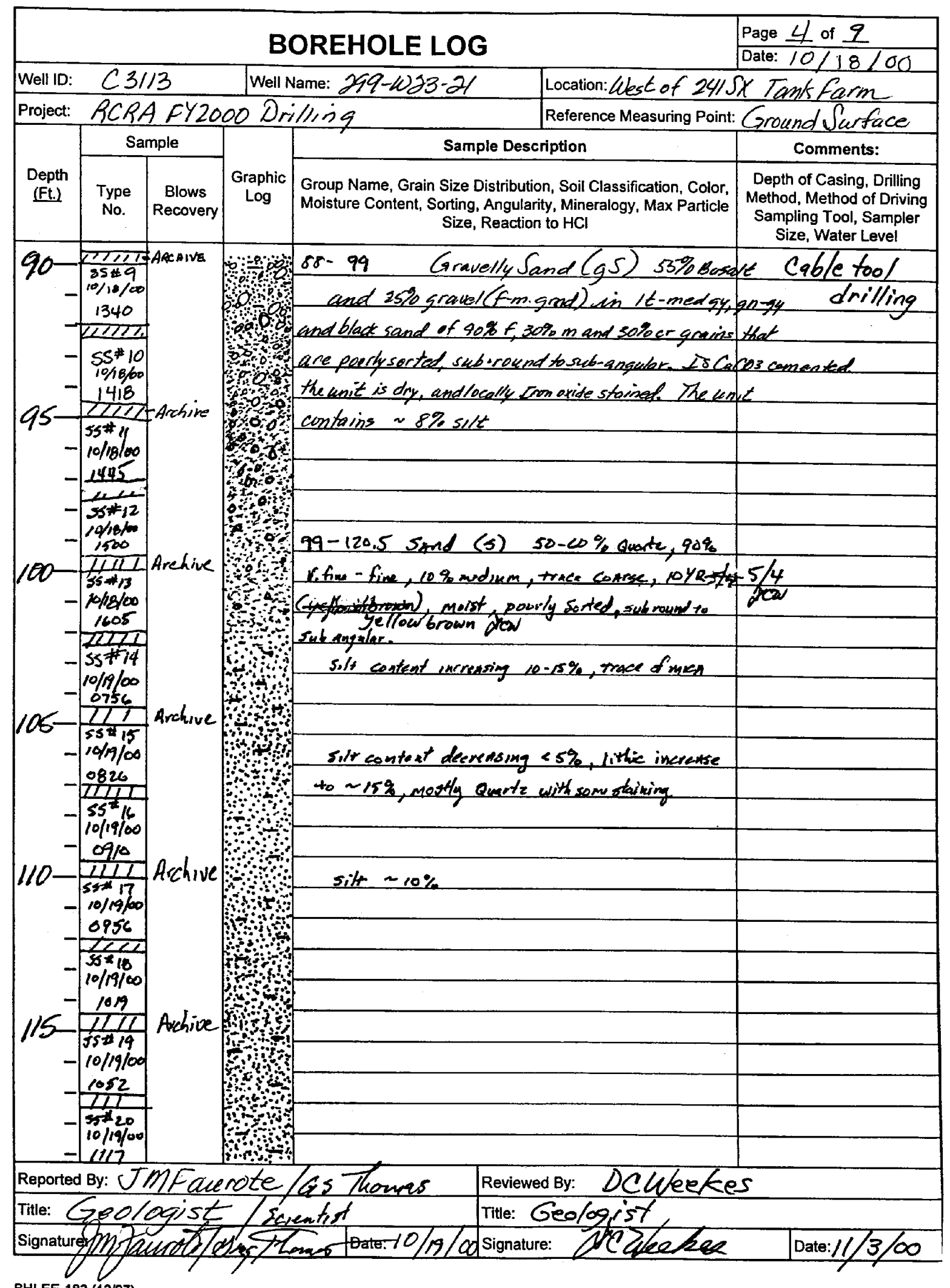

BHI-EE-183 (12/97) 


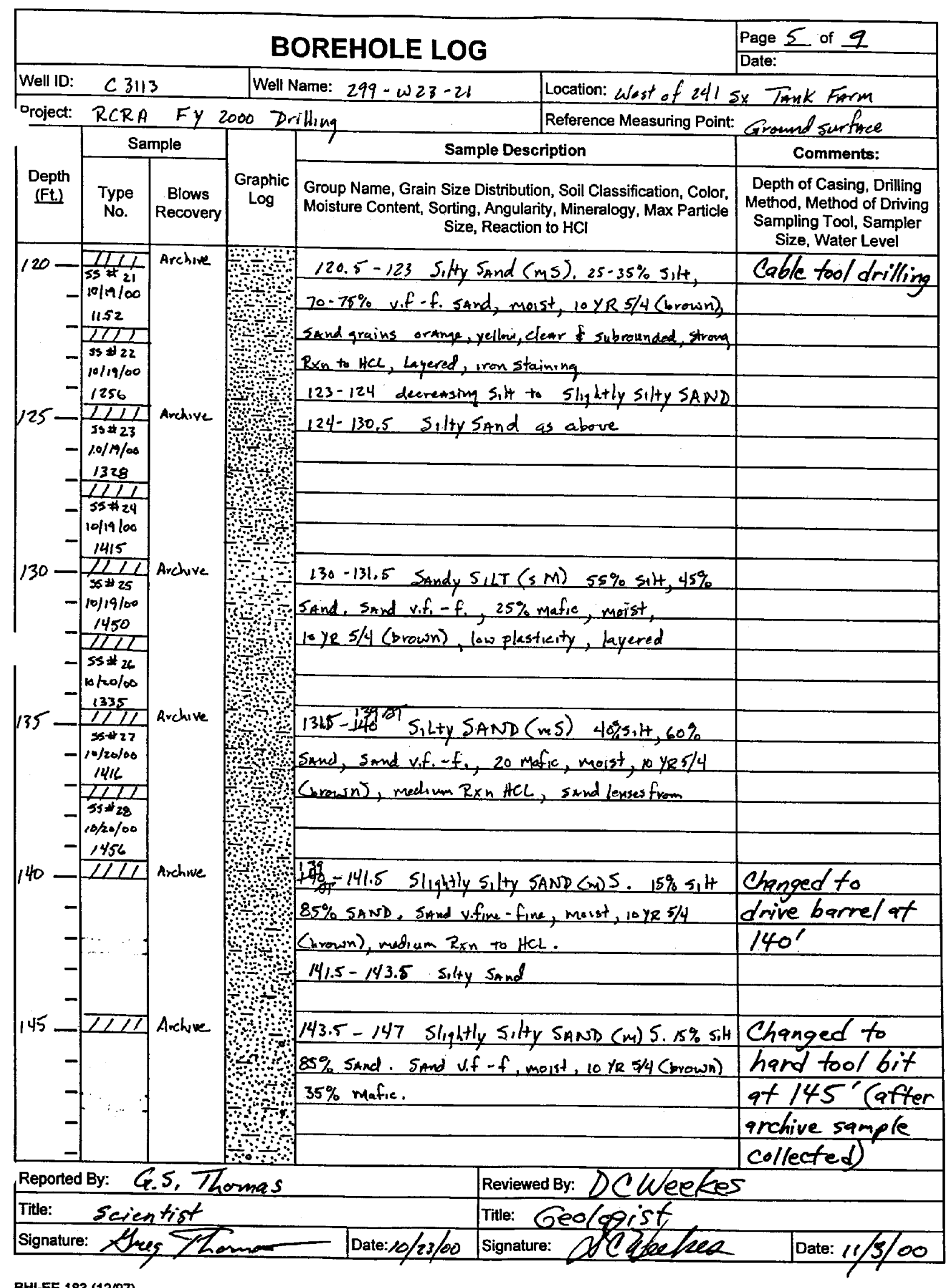

BHI-EE-183 (12/97) 


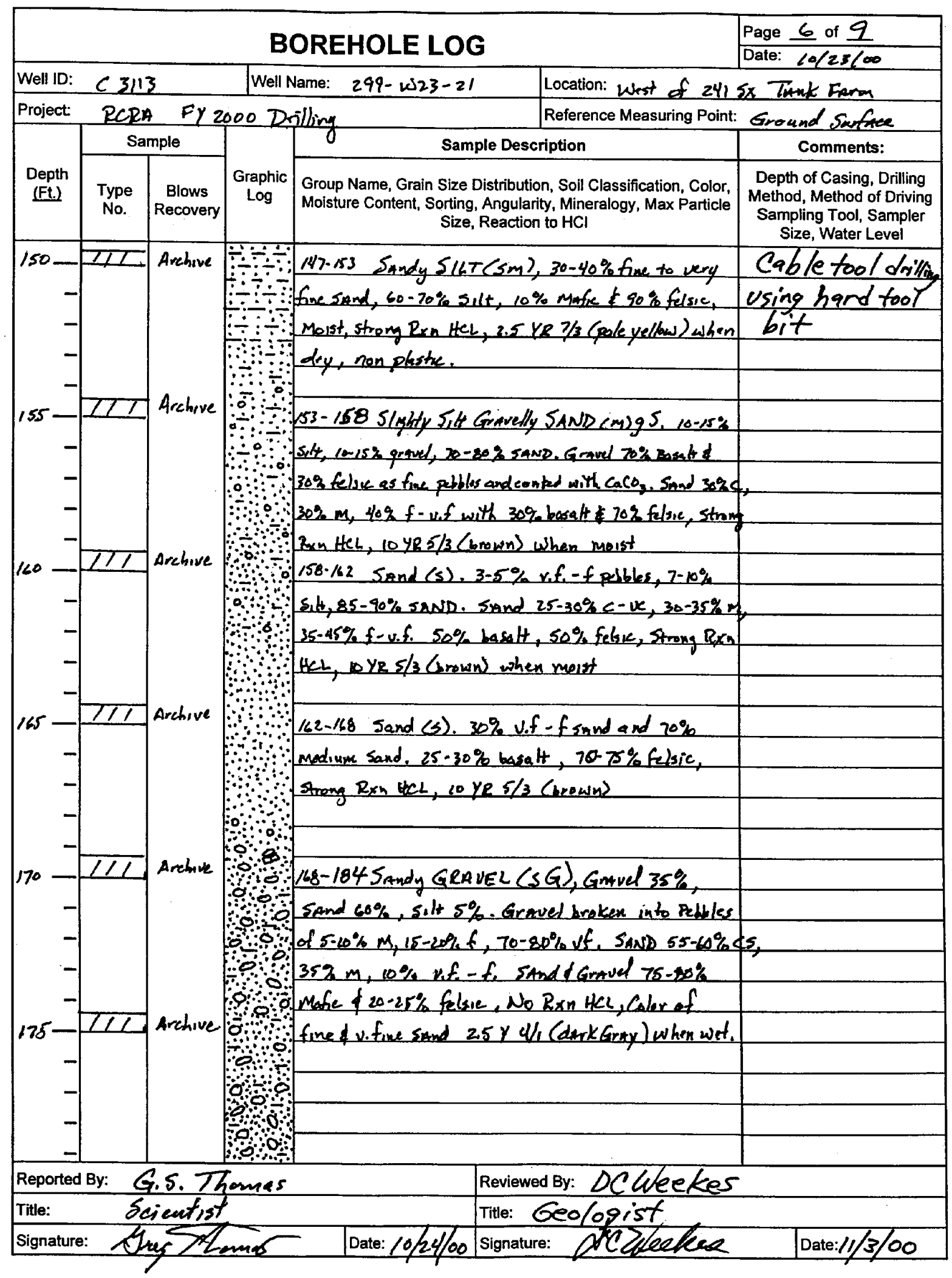

BHI-EE-183 (12/97) 


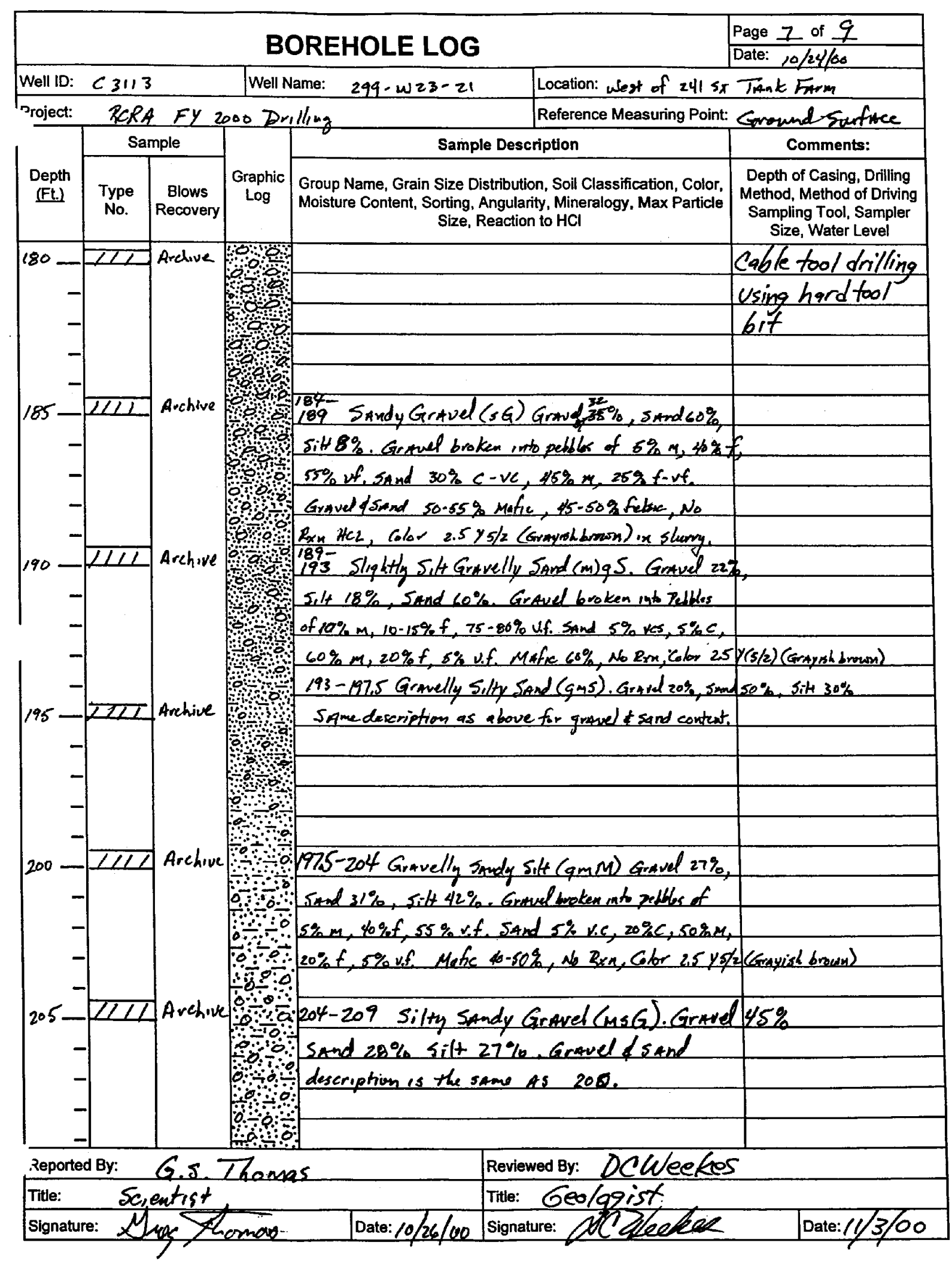

BHI-EE-183 (12/97) 







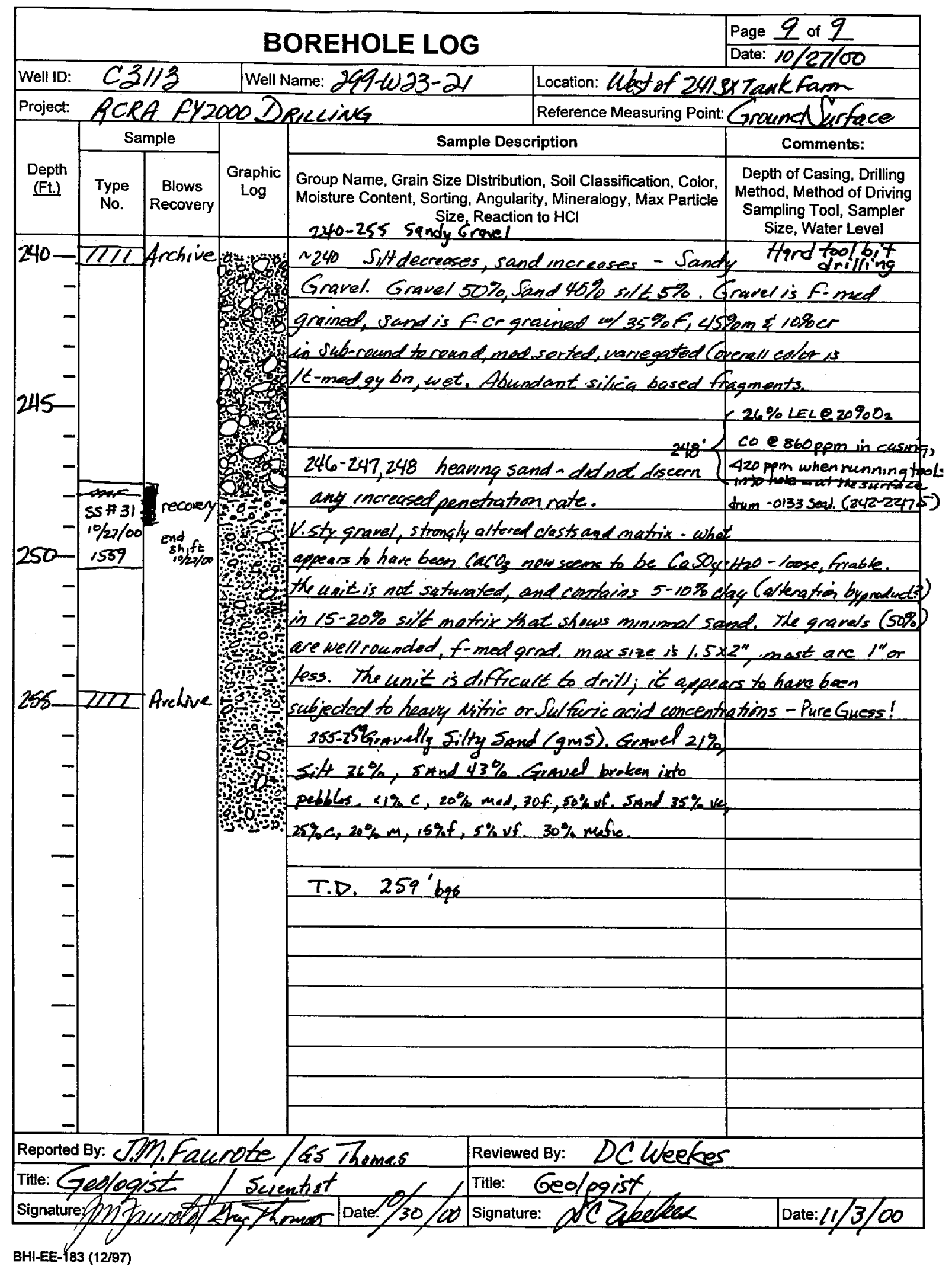




\section{Appendix B}

\section{Physical Properties Data}




\section{Appendix B}

\section{Physical Properties Data}

This Appendix includes the results of testing for particle size distribution on split spoon samples from the wells 299-W22-80, 299-W22-81, 299-W22-82, 299-W22-83, 299-W23-20, and 299-W23-21. The analyses were done by $\mathrm{CH} 2 \mathrm{M}$ Hill Hanford Inc using standard sieve techniques. 


\begin{tabular}{|c|c|c|c|c|c|c|}
\hline \multicolumn{7}{|c|}{ CH2M Hill Hantord, Inc. } \\
\hline WELL NAME & 299-W22-80 & DEPTH & $213.3^{\prime}-215.8^{\prime}$ & SAMPLE\# & W22-80-213.3 & WELL ID\# \\
\hline TESTED BY & JMW & CONTACT & Dave Weekes & PHONE & $372-9524$ & DATE $\quad 09 / 08 / 2000$ \\
\hline $\begin{array}{l}\text { SAMPLE } \\
\text { WT }(g)\end{array}$ & $\begin{array}{l}\text { SIEVE } \\
\text { SIZE IN. }\end{array}$ & $\begin{array}{l}\text { CUMULATIVE } \\
\text { WEIGHT(g) }\end{array}$ & $\begin{array}{l}\% \text { WEIGHT } \\
\text { RETAINED }\end{array}$ & $\begin{array}{c}\% \\
\text { PASSING }\end{array}$ & $\begin{array}{c}\text { Grain Size } \\
(\mathrm{mm})\end{array}$ & COMMENTS \\
\hline 982.30 & $2^{\prime \prime}$ & 0.0 & 0.0 & 100.0 & 50.80 & \\
\hline & $1.5^{\prime \prime}$ & 0.0 & 0.0 & 100.0 & 38.10 & \\
\hline & $3 / 4^{\prime \prime}$ & 167.4 & 17.0 & 83.0 & 19.05 & \\
\hline & $3 / 8^{\prime \prime}$ & 297.6 & 30.3 & 69.7 & 9.42 & \\
\hline & $\# 4$ & 377.7 & 38.5 & 61.5 & 4.70 & \\
\hline & $\# 10$ & 469.1 & 47.8 & 52.2 & 1.98 & \\
\hline & $\# 20$ & 551.9 & 56.2 & 43.8 & 0.83 & \\
\hline & $\# 40$ & 627.6 & 63.9 & 36.1 & 0.42 & \\
\hline & $\# 60$ & 761.1 & 77.5 & 22.5 & 0.25 & \\
\hline & $\# 100$ & 825.8 & 84.1 & 15.9 & 0.150 & \\
\hline & \#200 & 875.7 & 89.1 & 10.9 & 0.074 & \\
\hline
\end{tabular}

Sieve Analysis Data for Sample W22-80-213.3

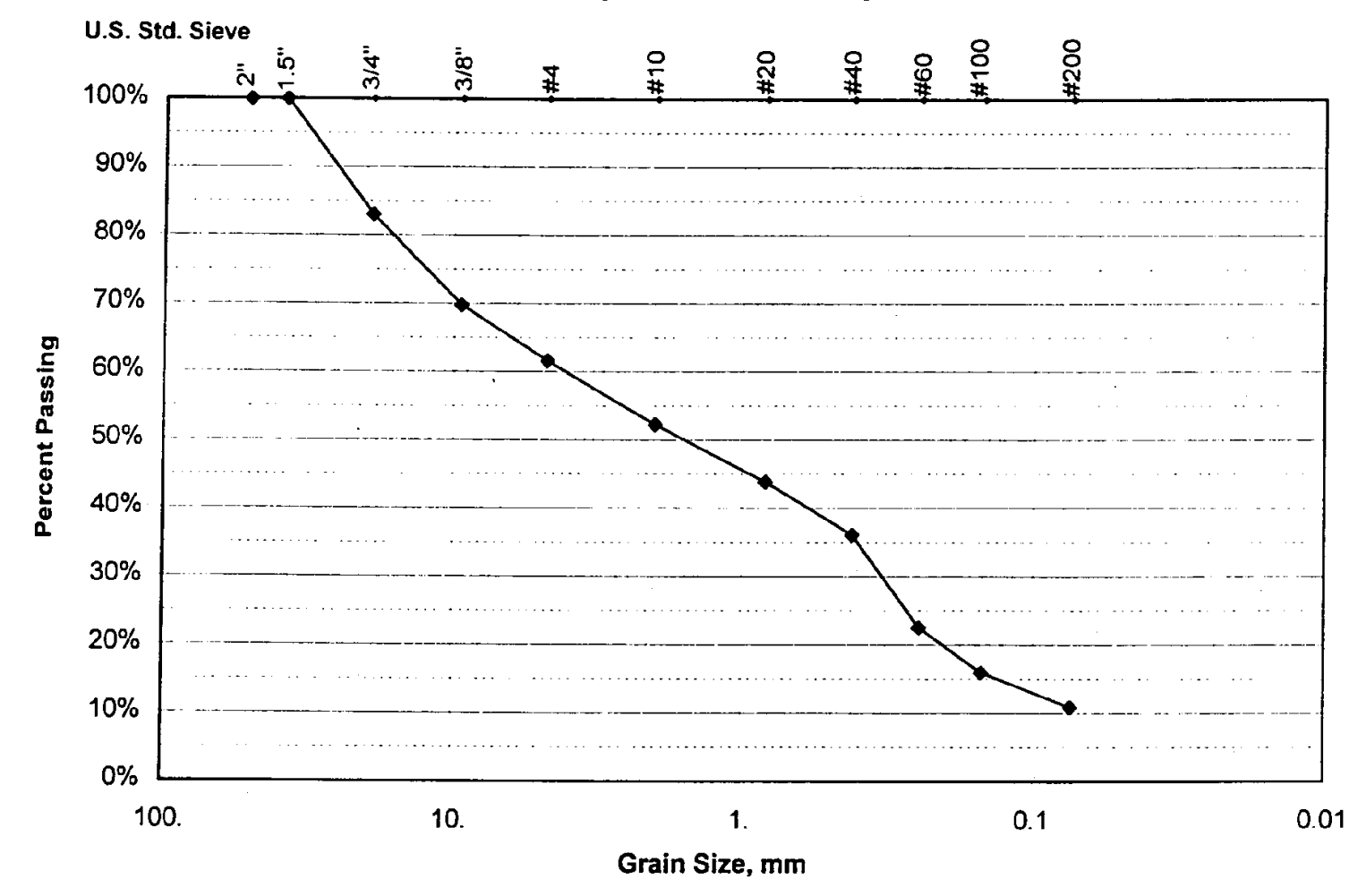

Comments: Silty Sandy Gravel

All data are accurately and completely recorded. Checked By: ArC Zleethes Date: $9 / 19 / 00$

B. 2 
CHzin Hill Hanford, Inc.

SIEVE ANALYSIS

\begin{tabular}{|c|c|c|c|c|c|c|}
\hline WELL NAME & 299-W22-80 & DEPTH & $232.0^{\prime}-234.5^{\prime}$ & SAMPLE\# & W22-80-232.0 & \begin{tabular}{|lr} 
WELL ID\# & C3115 \\
DATE
\end{tabular} \\
\hline TESTED BY & JMW & CONTACT & Dave Weekes & PHONE & $372-9524$ & $09 / 08 / 2000$ \\
\hline $\begin{array}{l}\text { SAMPLE } \\
W T(g)\end{array}$ & $\begin{array}{l}\text { SIEVE } \\
\text { SIZE IN. }\end{array}$ & $\begin{array}{l}\text { CUMULATIVE } \\
\text { WEIGHT(g) }\end{array}$ & $\begin{array}{l}\text { \% WEIGHT } \\
\text { RETAINED }\end{array}$ & $\begin{array}{c}\% \\
\text { PASSING }\end{array}$ & $\begin{array}{c}\text { Grain Size } \\
(\mathrm{mm})\end{array}$ & COMMENTS \\
\hline 925.30 & 2 & 0.0 & 0.0 & 100.0 & 50.80 & \\
\hline & 1.5 & 0.0 & 0.0 & 100.0 & 38.10 & \\
\hline & $3 / 4$ & 254.5 & 27.5 & 72.5 & 19.05 & \\
\hline & $3 / 8$ & 440.3 & 47.6 & 52.4 & 9.42 & \\
\hline & $\#$ & 529.3 & 57.2 & 42.8 & 4.70 & \\
\hline & $\# 1 C$ & 598.0 & 64.6 & 35.4 & 1.98 & \\
\hline & $\# 2 \mathrm{C}$ & 637.7 & 68.9 & 31.1 & 0.83 & \\
\hline & $\# 4 C$ & 678.2 & 73.3 & 26.7 & 0.42 & \\
\hline & $\# 6 \mathrm{C}$ & 780.7 & 84.4 & 15.6 & 0.25 & \\
\hline & $\# 100$ & 823.1 & 89.0 & 11.0 & 0.150 & \\
\hline & $\# 200$ & 853.8 & 92.3 & 7.7 & 0.074 & \\
\hline
\end{tabular}

Sieve Analysis Data for Sample W22-80-232.0

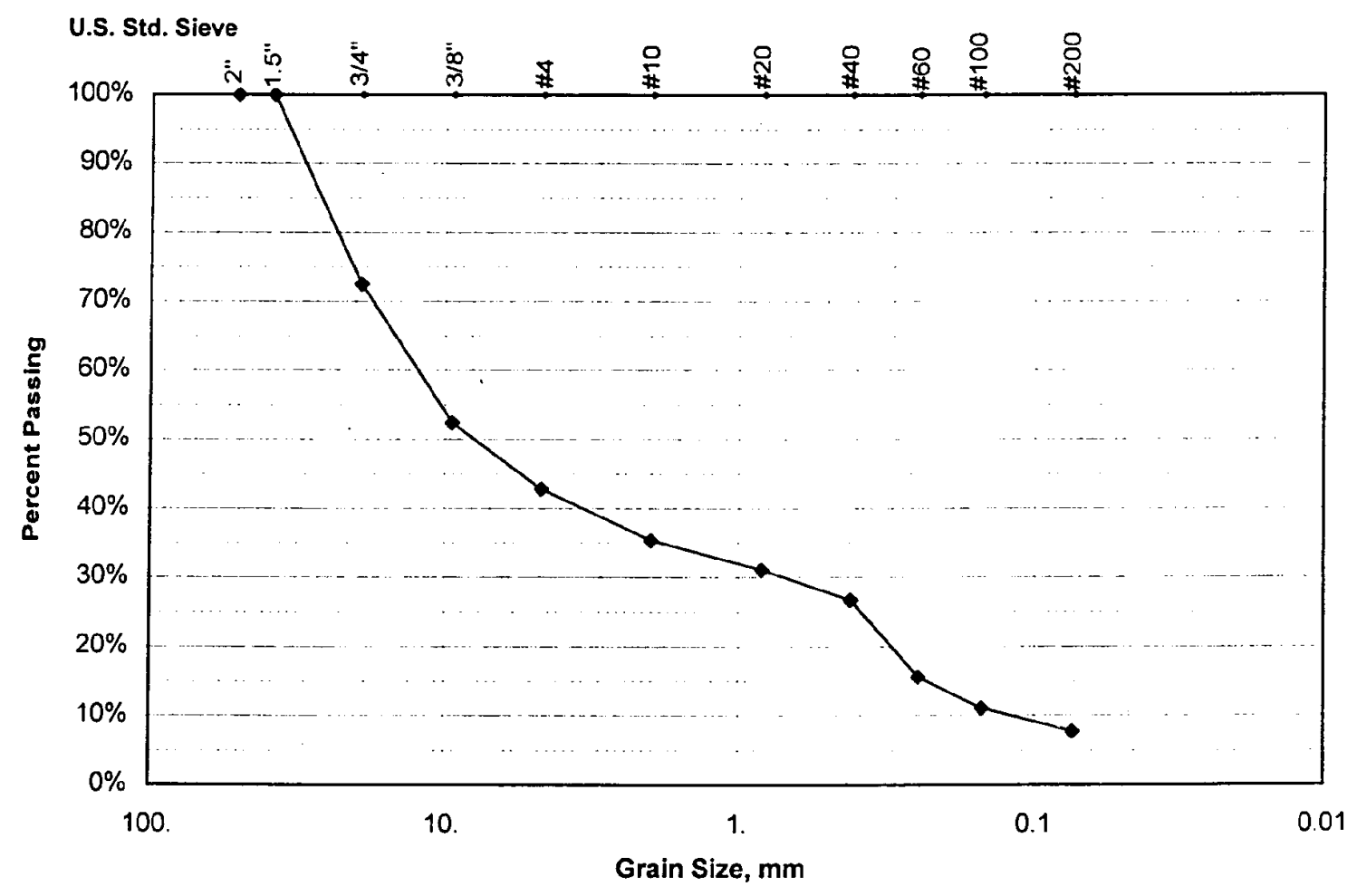

Comments: Sandy Gravel

All data are accuratgly and completely recorded.

Checked By: ACQleeled $\quad$ Date: $9 / 19 / 00$

B.3 
CH2M Hili Hanford, Inc.

SIEVE ANALYSIS

\begin{tabular}{|c|c|c|c|c|c|c|}
\hline $\begin{array}{l}\text { WELL NAME } \\
\text { TECTSOV }\end{array}$ & 299-W22-80 & DEPTH & $241.0^{\prime}-243.5^{\prime}$ & SAMPLE\# & $\overline{W 22-80-241.0}$ & \begin{tabular}{|lr} 
WELL ID\# & C3115 \\
DATE & $09 / 08 / 2000$ \\
\end{tabular} \\
\hline TESTED BY & JMW & CONTACT & Dave Weekes & PHONE & $372-9524$ & DATE $\quad 09 / 08 / 2000$ \\
\hline $\begin{array}{l}\text { SAMPLE } \\
W T(g) \\
\end{array}$ & $\begin{array}{l}\text { SIEVE } \\
\text { SIZE IN. }\end{array}$ & $\begin{array}{l}\text { CUMULATIVE } \\
\text { WEIGHT(g) }\end{array}$ & $\begin{array}{l}\text { \% WEIGHT } \\
\text { RETAINED }\end{array}$ & $\begin{array}{c}\% \\
\text { PASSING }\end{array}$ & $\begin{array}{l}\text { Grain Size } \\
(\mathrm{mm})\end{array}$ & COMMENTS \\
\hline \multirow[t]{11}{*}{663.90} & $2^{\prime \prime}$ & 0.0 & 0.0 & 100.0 & 50.80 & \\
\hline & $1.5^{\prime \prime}$ & $\overline{0.0}$ & 0.0 & 100.0 & 38.10 & \\
\hline & $3 / 4 "$ & $\overline{0.0}$ & 0.0 & 100.0 & 19.05 & \\
\hline & $3 / 8^{\prime \prime}$ & 0.0 & 0.0 & 100.0 & 9.42 & \\
\hline & $\# 4$ & 0.0 & 0.0 & 100.0 & 4.70 & \\
\hline & $\# 10$ & 0.0 & 0.0 & 100.0 & 1.98 & \\
\hline & $\# 20$ & 1.0 & 0.2 & 99.8 & 0.83 & \\
\hline & $\# 40$ & 141.6 & 21.3 & 78.7 & 0.42 & \\
\hline & $\# 60$ & 568.6 & 85.6 & 14.4 & 0.25 & \\
\hline & $\# 100$ & 631.2 & 95.1 & 4.9 & 0.150 & \\
\hline & $\# 200$ & 651.4 & 98.1 & 1.9 & 0.074 & \\
\hline
\end{tabular}

Sieve Analysis Data for Sample W22-80-241.0

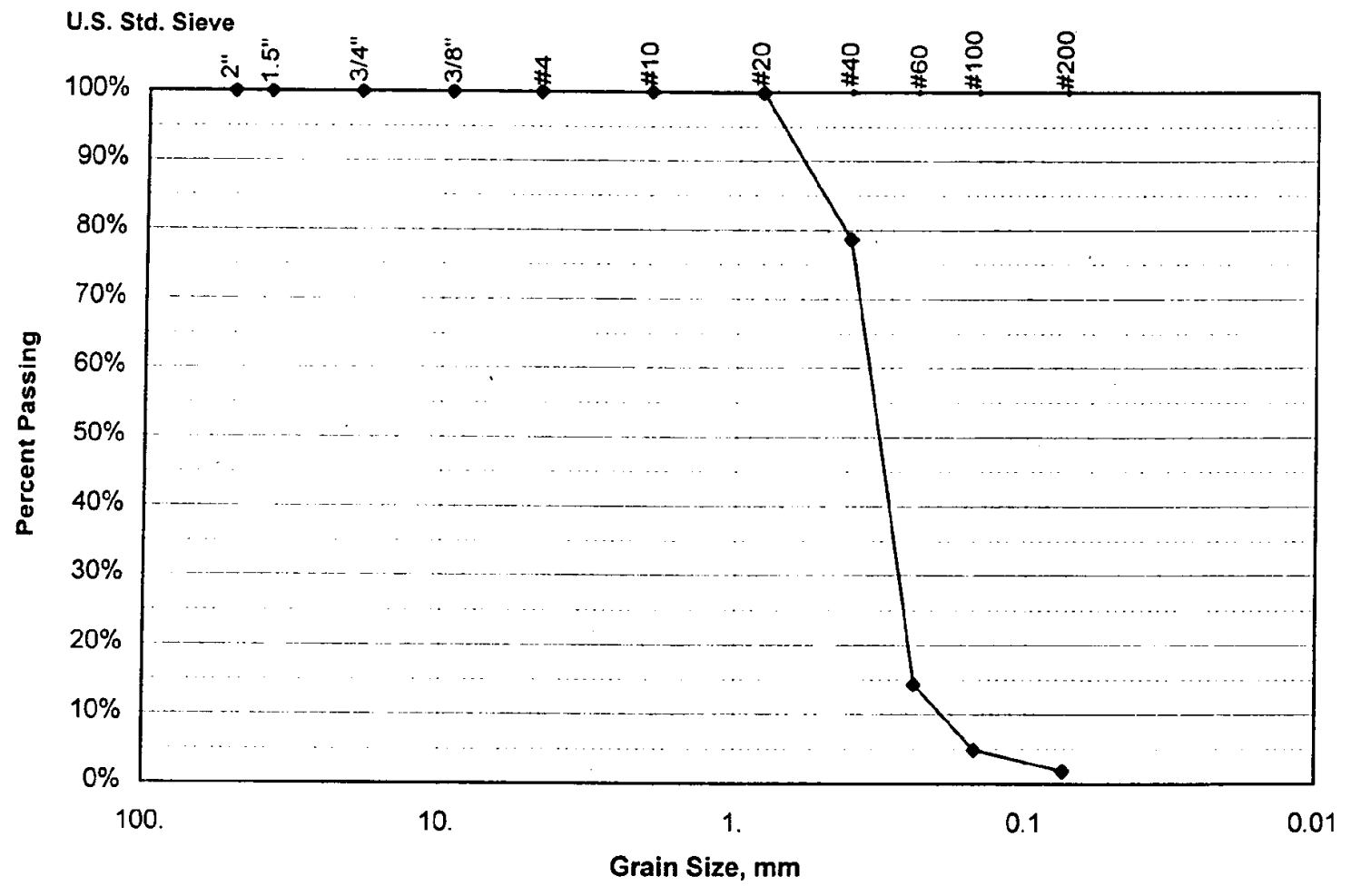

Comments: Sand (Well Heaving Sand)

All data are accurately and completely recorded.

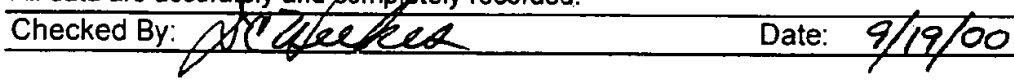

B. 4 
CH2M Hill Hantord, lnc.

SIEVE ANALYSIS

\begin{tabular}{|c|c|c|c|c|c|c|}
\hline $\begin{array}{l}\text { WELL NAME } \\
\text { TESTED BYY }\end{array}$ & $299-W \overline{22-81}$ & DEPTH & $238.0^{\prime}-239.5^{\prime}$ & SAMPLE\# & W22-81-238.0 & $\begin{array}{l}\text { WELL ID\# } \\
\end{array}$ \\
\hline TESTED BY & John Wimett & CONTACT & Dave Weekes & PHONE & $372-9130$ & $01 / 26 / 2001$ \\
\hline $\begin{array}{l}\text { SAMPLE } \\
\text { WT (g) } \\
\end{array}$ & $\begin{array}{l}\text { SIEVE } \\
\text { SIZE IN. }\end{array}$ & \begin{tabular}{|l} 
CUMULATIVE \\
WEIGHT(g) \\
\end{tabular} & $\begin{array}{l}\text { \% WEIGHT } \\
\text { RETAINED }\end{array}$ & $\begin{array}{c}\% \\
\text { PASSING } \\
\end{array}$ & $\begin{array}{c}\text { Grain Size } \\
(\mathrm{mm})\end{array}$ & COMMENTS \\
\hline 980.10 & $2 "$ & 0.0 & 0.0 & 100.0 & 50.80 & \\
\hline & $1.5^{\prime \prime}$ & 0.0 & 0.0 & 100.0 & 38.10 & \\
\hline & $3 / 4^{\prime \prime}$ & 124.9 & 12.7 & 87.3 & 19.05 & \\
\hline & $3 / 8^{\prime \prime}$ & 236.9 & 24.2 & 75.8 & 9.42 & \\
\hline & \#4 & 375.9 & 38.4 & 61.6 & 4.70 & \\
\hline & $\# 10$ & 525.2 & 53.6 & 46.4 & 1.98 & \\
\hline & $\# 20$ & 621.3 & 63.4 & 36.6 & 0.83 & \\
\hline & $\# 40$ & 671.2 & 68.5 & 31.5 & 0.42 & \\
\hline & $\# 60$ & 713.0 & 72.7 & 27.3 & 0.25 & \\
\hline & $\# 100$ & 775.4 & 79.1 & 20.9 & 0.150 & \\
\hline & $\# 200$ & 850.3 & 86.8 & 13.2 & 0.074 & \\
\hline
\end{tabular}

Sieve Analysis Data for Sample W22-81-238.0

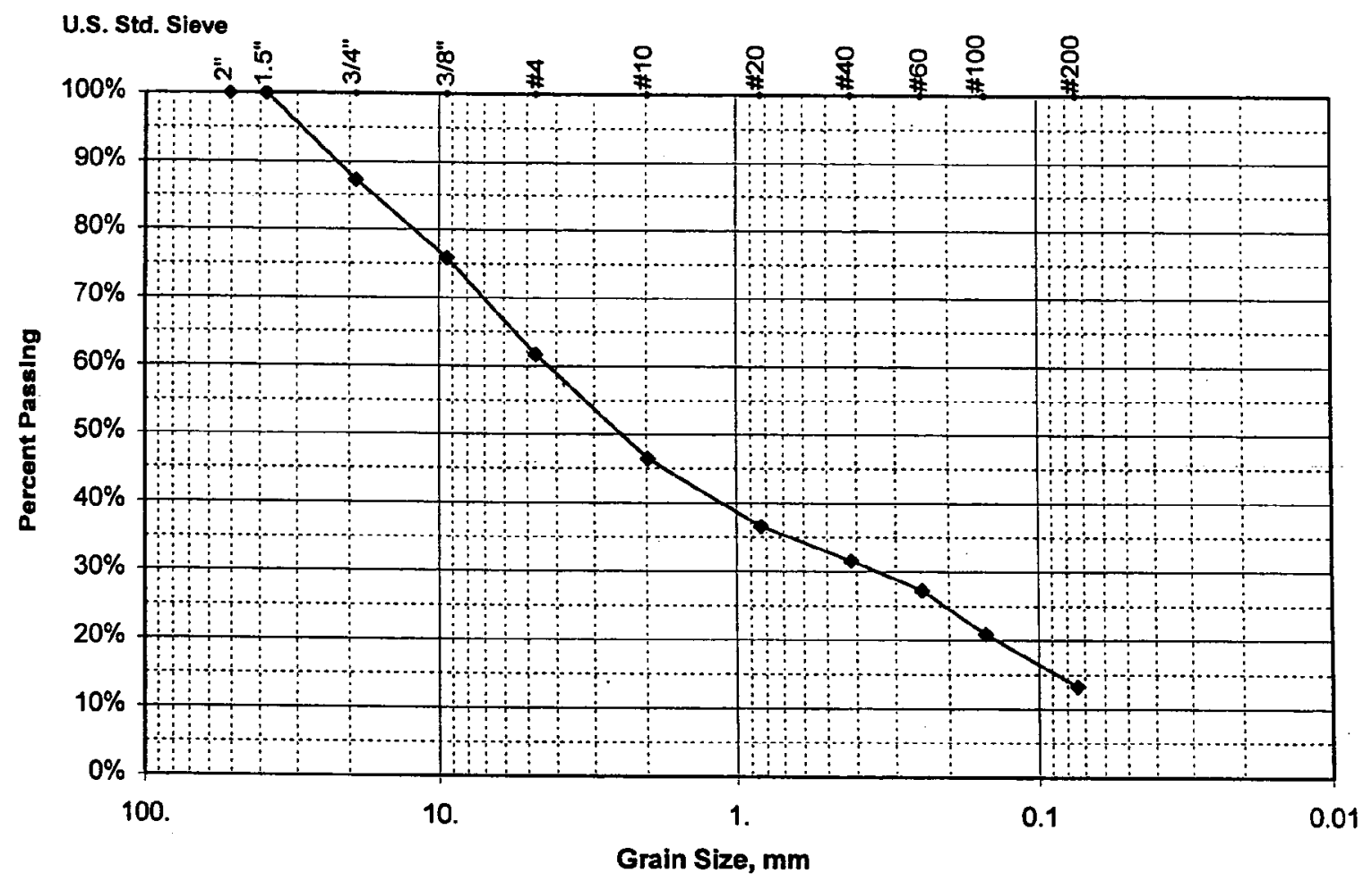

Comments: Silty Sandy Gravel

All data are accuratel and complately recorded. Checked By: AXTherter Date: $4 / 3 / 01$ 
CH21 Thili Hanford, Inc.

SIEVE ANALYSIS

\begin{tabular}{|c|c|c|c|c|c|c|}
\hline WELL NAME & 299-W22-81 & DEPTH & $246.3^{\prime}-247.8^{\prime}$ & SAMPLE\# & W22-81-246.3 & WELL ID\# \\
\hline TESTED BY & John Wimett & CONTACT & Dave Weekes & PHONE & $372-9130$ & $01 / 26 / 2001$ \\
\hline $\begin{array}{l}\text { SAMPLE } \\
W T(g)\end{array}$ & $\begin{array}{l}\text { SIEVE } \\
\text { SIZE IN. }\end{array}$ & $\begin{array}{l}\text { CUMULATIVE } \\
\text { WEIGHT(g) }\end{array}$ & $\begin{array}{l}\% \text { WEIGHT } \\
\text { RETAINED }\end{array}$ & $\begin{array}{c}\% \\
\text { PASSING }\end{array}$ & $\begin{array}{c}\text { Grain Size } \\
\text { (mm) }\end{array}$ & COMMENTS \\
\hline \multirow[t]{11}{*}{982.80} & $2^{\prime \prime}$ & 0.0 & 0.0 & 100.0 & 50.80 & \\
\hline & $1.5^{\prime \prime}$ & 0.0 & 0.0 & 100.0 & 38.10 & \\
\hline & $3 / 4^{\prime \prime}$ & 177.7 & 18.1 & 81.9 & 19.05 & \\
\hline & $3 / 8^{\prime \prime}$ & 352.1 & 35.8 & 64.2 & 9.42 & \\
\hline & $\# 4$ & 487.1 & 49.6 & 50.4 & 4.70 & \\
\hline & $\# 10$ & 595.6 & 60.6 & 39.4 & 1.98 & \\
\hline & $\# 20$ & 664.3 & 67.6 & 32.4 & 0.83 & \\
\hline & $\# 40$ & 715.5 & 72.8 & 27.2 & 0.42 & \\
\hline & $\# 60$ & 795.2 & 80.9 & 19.1 & 0.25 & \\
\hline & $\# 100$ & 857.3 & 87.2 & $\overline{12.8}$ & 0.150 & \\
\hline & $\# 200$ & 897.0 & 91.3 & 8.7 & 0.074 & \\
\hline
\end{tabular}

Sieve Analysis Data for Sample W22-81-246.3

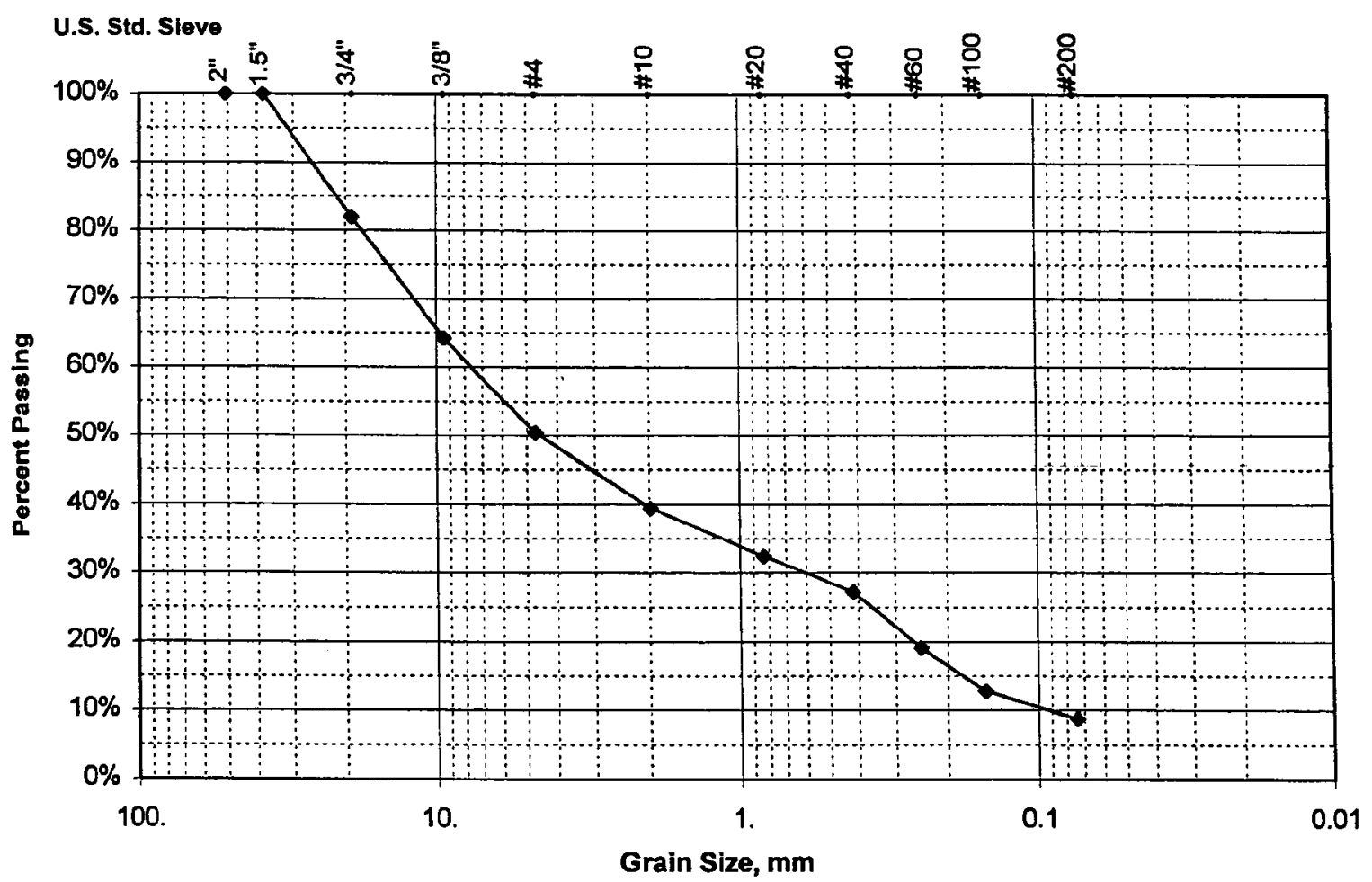

Comments: Sandy Gravel

All data are accuratelt and completely recorded. Checked By: DCLee Ler Date:

B. 6 
CH2M Hill Hanford, Tnc.

SIEVE ANALYSIS

\begin{tabular}{|c|c|c|c|c|c|c|}
\hline $\begin{array}{l}\text { WELL NAME } \\
\text { TESTED BY }\end{array}$ & 299-W22-81 & $\begin{array}{l}\text { DEPTH } \\
\text { CONTACT }\end{array}$ & $260.5^{\prime}-262.5^{\prime}$ & $\begin{array}{l}\text { SAMPLE\# } \\
\text { PHONF }\end{array}$ & $\frac{W 22-81-260.5}{372-0130}$ & \begin{tabular}{|l|l|} 
WELL ID\# & C3123 \\
DATE
\end{tabular} \\
\hline & & & & & & \\
\hline $\begin{array}{l}\text { SAMPLE } \\
W T(g)\end{array}$ & $\begin{array}{l}\text { SIEVE } \\
\text { SIZE IN. }\end{array}$ & \begin{tabular}{|} 
CUMMULATIVE \\
WEIGHT(g)
\end{tabular} & $\begin{array}{l}\text { \%WEIGHT } \\
\text { RETAINED }\end{array}$ & $\begin{array}{c}\% \\
\text { PASSING }\end{array}$ & $\begin{array}{c}\text { Grain Size } \\
\text { (mm) }\end{array}$ & COMMENTS \\
\hline \multirow[t]{11}{*}{968.50} & $2^{2 \prime}$ & 0.0 & 0.0 & 100.0 & 50.80 & \\
\hline & $1.5^{\prime \prime}$ & 0.0 & 0.0 & 100.0 & 38.10 & \\
\hline & $3 / 4^{\prime \prime}$ & 184.1 & 19.0 & 81.0 & 19.05 & \\
\hline & $3 / 8^{\prime \prime}$ & 368.3 & 38.0 & 62.0 & 9.42 & \\
\hline & \#4 & 507.8 & 52.4 & 47.6 & 4.70 & \\
\hline & $\# 10$ & 617.6 & 63.8 & 36.2 & 1.98 & \\
\hline & $\# 20$ & 668.9 & 69.1 & 30.9 & 0.83 & \\
\hline & $\# 40$ & 702.7 & 72.6 & 27.4 & 0.42 & \\
\hline & $\# 60$ & 811.9 & 83.8 & 16.2 & 0.25 & \\
\hline & $\# 100$ & 869.7 & 89.8 & 10.2 & 0.150 & \\
\hline & $\# 200$ & 900.6 & 93.0 & 7.0 & 0.074 & \\
\hline
\end{tabular}

Sieve Analysis Data for Sample W22-81-260.5

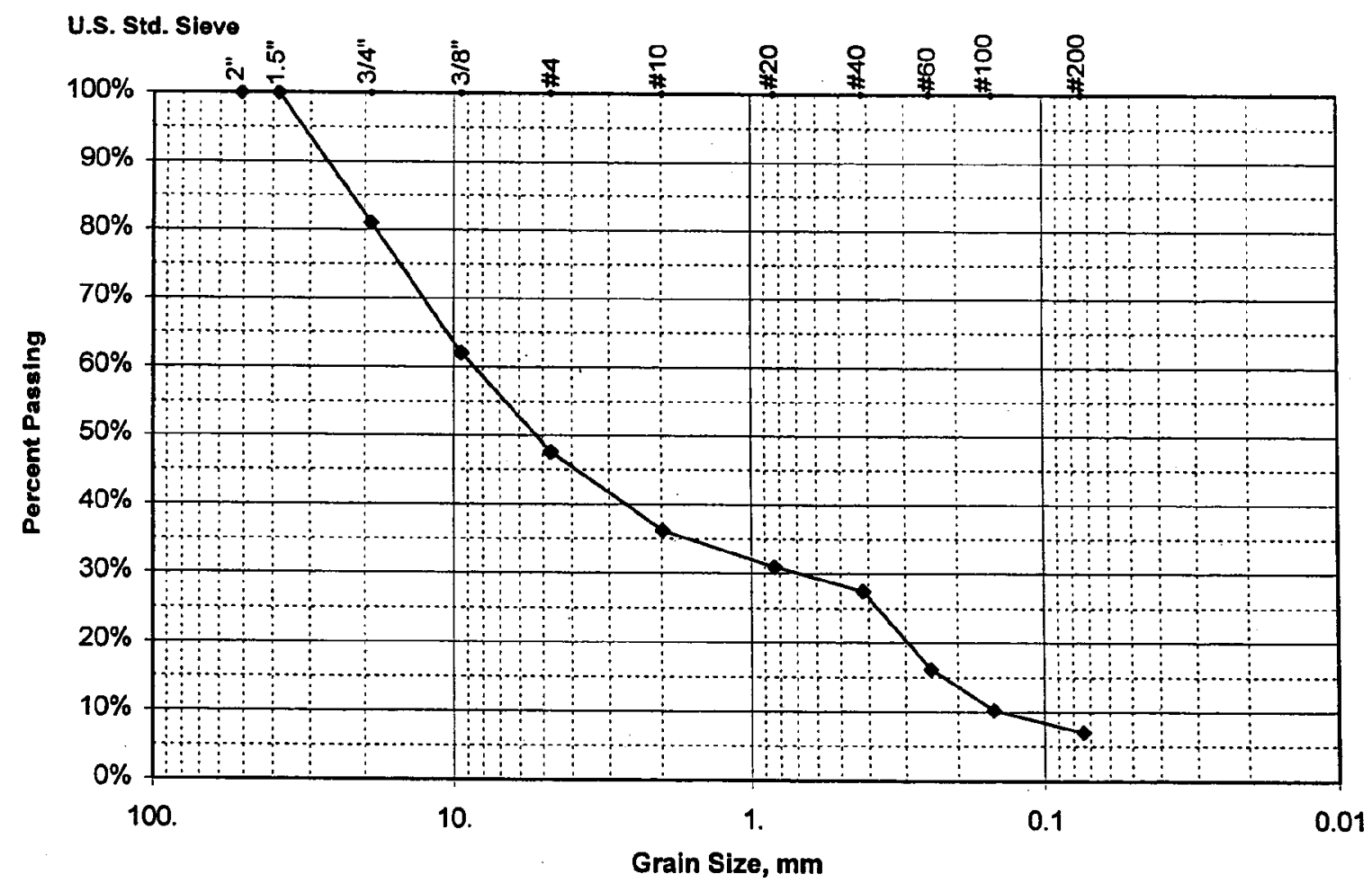

Comments: Sandy Gravel

All data are accurafely and completely recorded. Checked By: Whecter Date: $4 / 3 / 01$

B.7 


\begin{tabular}{|c|c|c|c|c|c|c|}
\hline \multicolumn{7}{|c|}{ CH2M Hill hanford, Inc. } \\
\hline WELL NAME & 299-W22-83 & DEPTH & $233.0^{\prime}-234.0^{\prime}$ & SAMPLE\# & W22-83-233.0 & WELL ID\# \\
\hline TESTED BY & John Wimett & CONTACT & Dave Weekes & PHONE & $372-9130$ & $03 / 23 / 2001$ \\
\hline $\begin{array}{l}\text { SAMPLE } \\
W T(g) \\
\end{array}$ & $\begin{array}{c}\text { SIEVE } \\
\text { SIZE IN. }\end{array}$ & $\begin{array}{c}\text { CUMULATIVE } \\
\text { WEIGHT(g) }\end{array}$ & $\begin{array}{l}\% \text { WEIGHT } \\
\text { RETAINED }\end{array}$ & $\begin{array}{c}\% \\
\text { PASSING }\end{array}$ & $\begin{array}{c}\text { Grain Size } \\
(\mathrm{mm})\end{array}$ & COMMENTS \\
\hline 983.00 & $2^{\prime \prime}$ & 0.0 & 0.0 & 100.0 & 50.80 & \\
\hline & $1.5^{\prime \prime}$ & 0.0 & 0.0 & 100.0 & 38.10 & \\
\hline & $3 / 4^{\prime \prime}$ & 244.7 & 24.9 & 75.1 & 19.05 & \\
\hline & $3 / 8^{\prime \prime}$ & 407.6 & 41.5 & 58.5 & 9.42 & \\
\hline & \#4 & 500.2 & 50.9 & 49.1 & 4.70 & \\
\hline & \#10 & 574.4 & 58.4 & 41.6 & 1.98 & \\
\hline & $\# 20$ & 634.4 & 64.5 & 35.5 & 0.83 & \\
\hline & $\# 40$ & 679.2 & 69.1 & 30.9 & 0.42 & \\
\hline & $\# 60$ & 765.4 & 77.9 & 22.1 & 0.25 & \\
\hline & $\# 100$ & 832.8 & 84.7 & 15.3 & 0.150 & \\
\hline & $\# 200$ & 880.7 & 89.6 & 10.4 & 0.074 & \\
\hline
\end{tabular}

Sieve Analysis Data for Sample W22-83-233.0

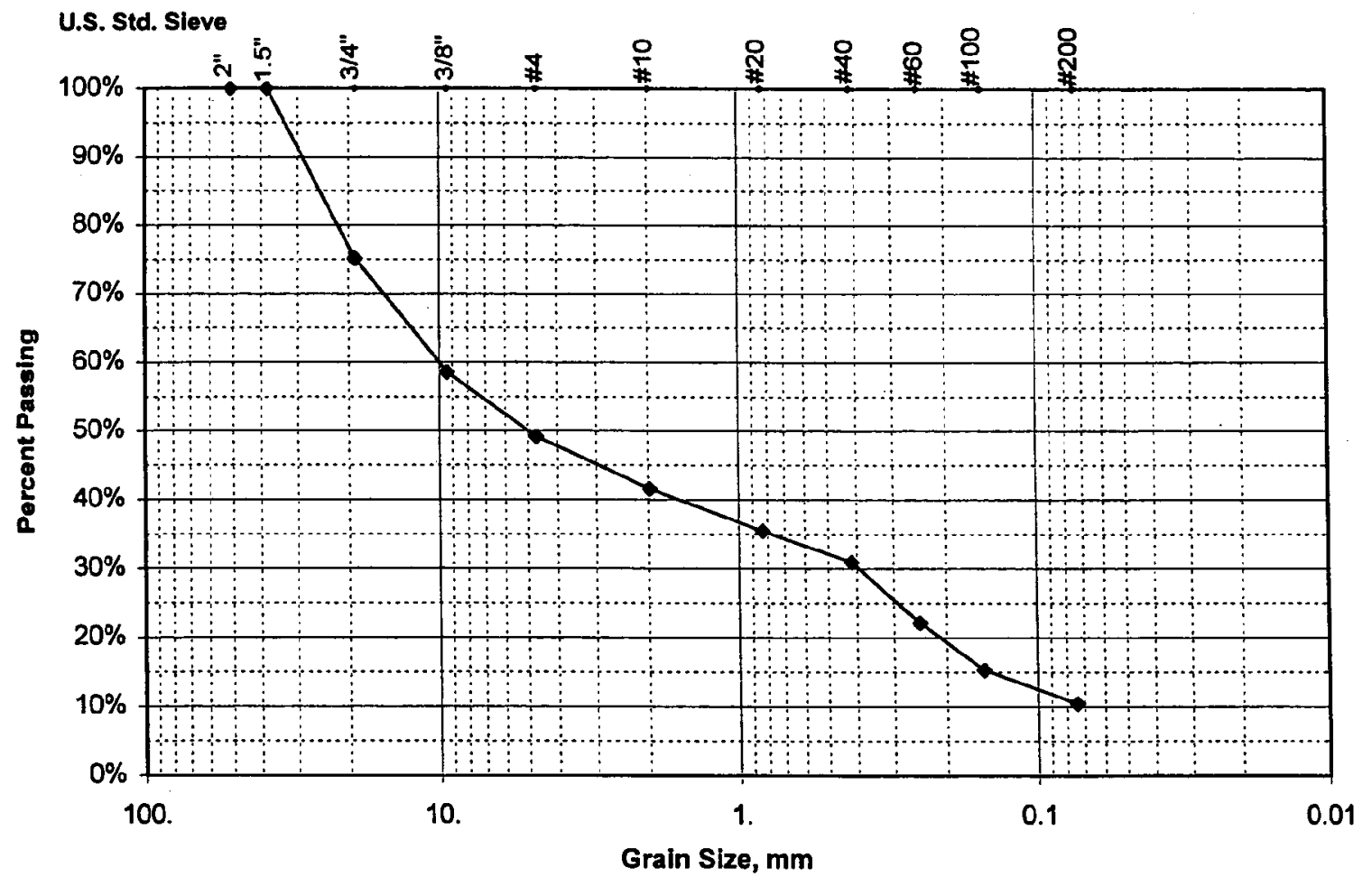

Comments: Silty Sandy Gravel

All data are accurately and complegely recorded.

Checked By: ACQPeeler Date: $473 / 01$

B. 8 


\begin{tabular}{|c|c|c|c|c|c|c|}
\hline & & & $\begin{array}{l}\text { 72M Hill Hant } \\
\text { SIEVE ANAl }\end{array}$ & $\begin{array}{l}\text { ord, Inc. } \\
\text { YSIS }\end{array}$ & & \\
\hline WELL NAME & $299-W 22-83$ & $\overline{\text { DEPTH }}$ & $248.0^{\prime}-249.0^{\prime}$ & SAMPLE\# & W22-83-248.0 & WELL ID\# \\
\hline TESTED BY & John Wimett & CONTACT & Dave Weekes & PHONE & $372-9130$ & $03 / 23 / 2001$ \\
\hline $\begin{array}{l}\text { SAMPLE } \\
W T(g)\end{array}$ & $\begin{array}{l}\text { SIEVE } \\
\text { SIZE IN. }\end{array}$ & $\begin{array}{l}\text { CUMULATIVE } \\
\text { WEIGHT(g) }\end{array}$ & $\begin{array}{l}\% \text { WEIGHT } \\
\text { RETAINED }\end{array}$ & $\begin{array}{c}\% \\
\text { PASSING }\end{array}$ & $\begin{array}{c}\text { Grain Size } \\
\text { (mm) }\end{array}$ & COMMENTS \\
\hline 963.70 & $2 "$ & 0.0 & 0.0 & 100.0 & 50.80 & \\
\hline & $1.5^{\prime \prime}$ & 108.8 & 11.3 & 88.7 & 38.10 & \\
\hline & $3 / 4^{\prime \prime}$ & 248.5 & 25.8 & 74.2 & 19.05 & \\
\hline & $3 / 8^{\prime \prime}$ & 354.0 & 36.7 & 63.3 & 9.42 & \\
\hline & $\# 4$ & 450.2 & 46.7 & 53.3 & 4.70 & \\
\hline & $\# 10$ & 548.6 & 56.9 & 43.1 & 1.98 & \\
\hline & $\# 20$ & 618.4 & 64.2 & 35.8 & 0.83 & \\
\hline & $\# 40$ & 667.4 & 69.3 & 30.7 & 0.42 & \\
\hline & $\# 60$ & 721.4 & 74.9 & 25.1 & 0.25 & \\
\hline & $\# 100$ & 780.8 & 81.0 & 19.0 & 0.150 & \\
\hline & $\# 200$ & 832.6 & 86.4 & 13.6 & 0.074 & \\
\hline
\end{tabular}

\section{Sieve Analysis Data for Sample W22-83-248.0}

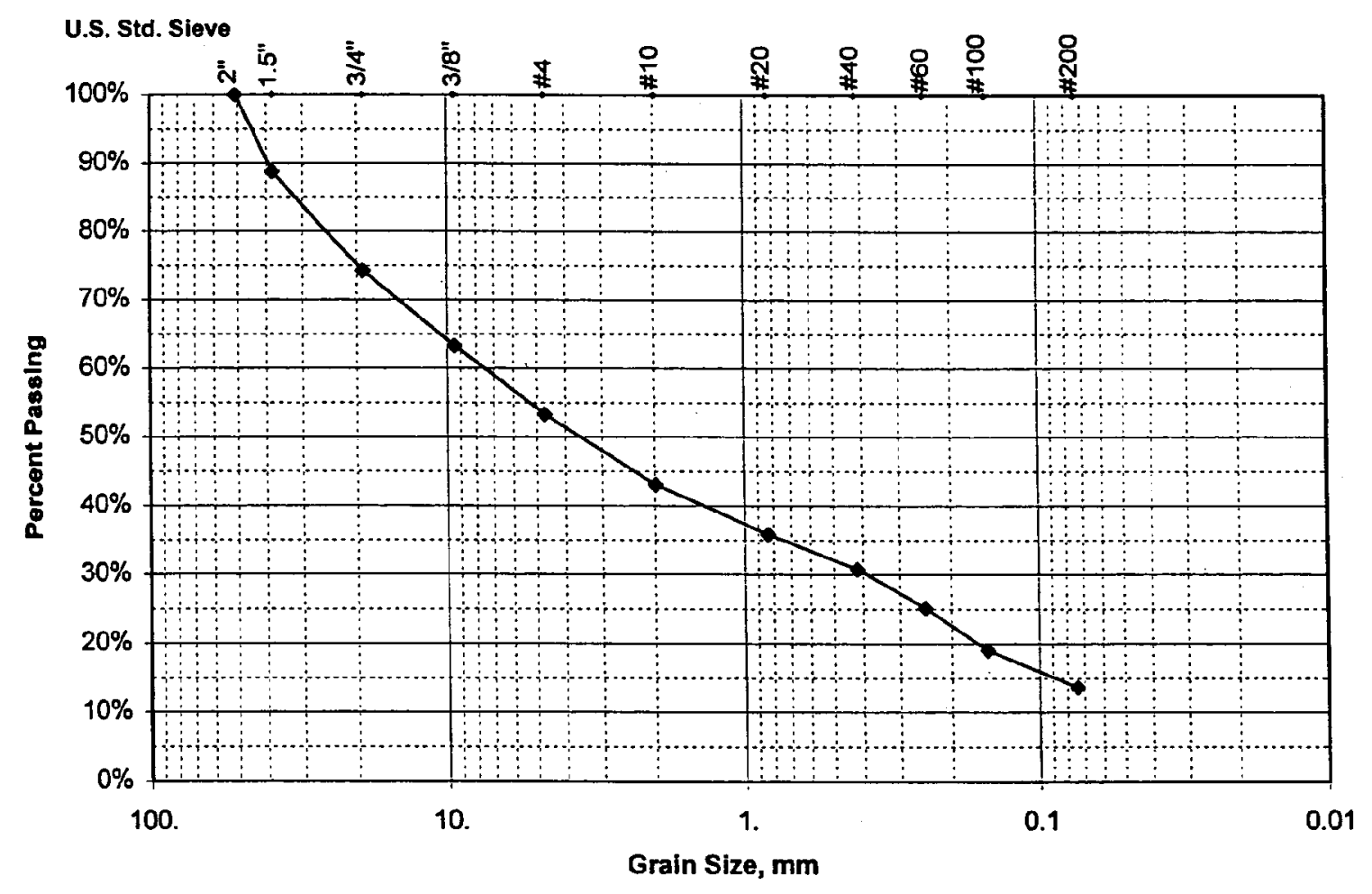

Comments: Silty Sandy Gravel

All data are accuratefly and complogely recorded. Checked By: N1 Yleeper Date: $4 / 3 / 01$ 
CH2M Hiltianford, Inc.

SIEVE ANALYSIS

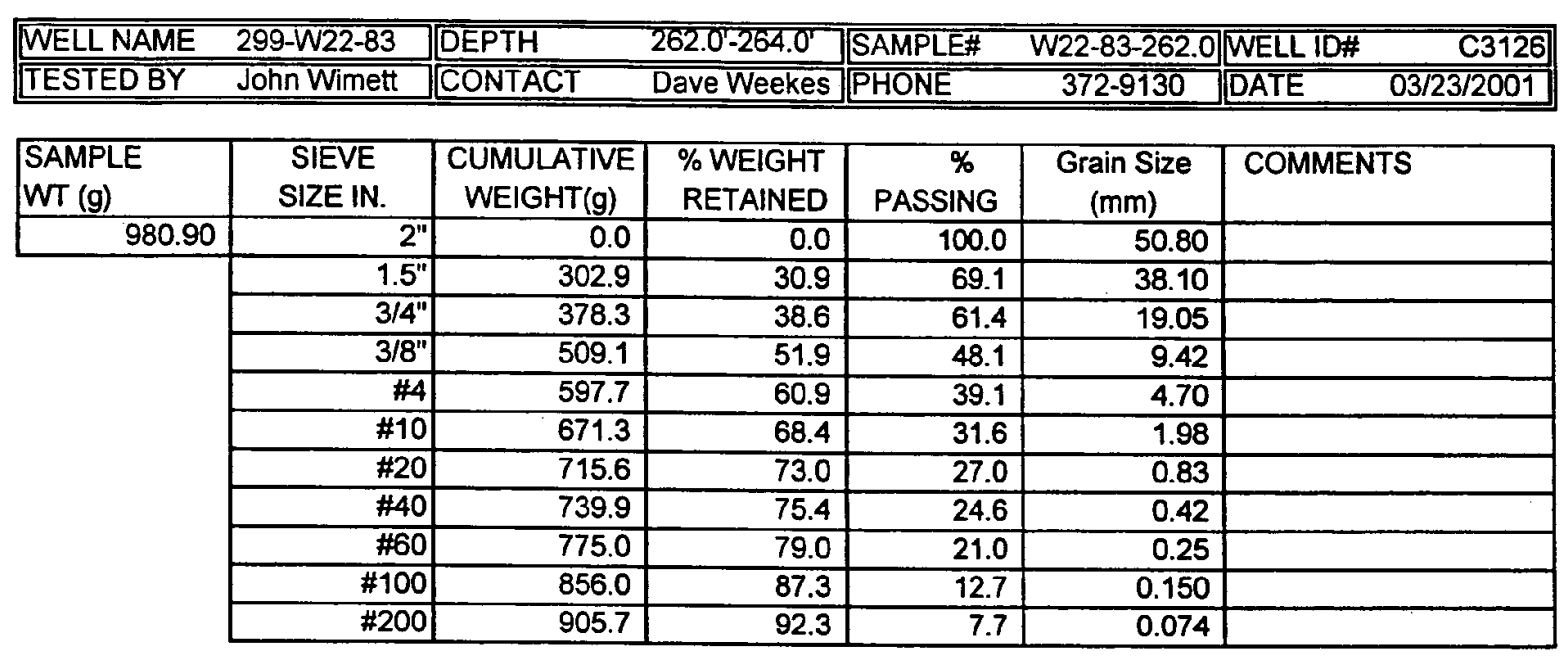

Sieve Analysis Data for Sample W22-83-262.0



Comments: Sandy Gravel

All data are accurately nd completely recorded.

Checked By: Drefeeler Date: $4 / 3 / 01$

B. 10 


\begin{tabular}{|c|c|c|c|c|c|c|}
\hline \multicolumn{7}{|c|}{ CHzh HIIITAntord, Inc. } \\
\hline WELL NAME & 299-W23-20 & DEPTH & $219.5^{\top}-220.0^{\prime}$ & SAMPLE\# & W23-20-219.5 & WELL ID\# \\
\hline TESTED BY & JMW & CONTACT & Dave Weekes & PHONE & $372-9524$ & $08 / 02 / 2000$ \\
\hline $\begin{array}{l}\text { SAMPLE } \\
\text { WT (g) }\end{array}$ & $\begin{array}{c}\text { SIEVE } \\
\text { SIZE IN. }\end{array}$ & $\begin{array}{l}\begin{array}{l}\text { CUMULATINE } \\
\text { WEIGHT(g) }\end{array} \\
\end{array}$ & $\begin{array}{l}\% \text { WEIGHT } \\
\text { RETAINED }\end{array}$ & $\begin{array}{c}\% \\
\text { PASSING } \\
\end{array}$ & $\begin{array}{c}\text { Grain Size } \\
(\mathrm{mm})\end{array}$ & COMMENTS \\
\hline 708.60 & $2^{n}$ & 0.0 & 0.0 & 100.0 & 50.80 & \\
\hline & $1.5^{m}$ & 0.0 & 0.0 & 100.0 & 38.10 & \\
\hline & $3 / 4^{\prime \prime}$ & 111.9 & 15.8 & 84.2 & 19.05 & \\
\hline & $3 / 8^{\prime \prime}$ & 219.9 & 31.0 & 69.0 & 9.42 & \\
\hline & \#4 & 309.7 & 43.7 & 56.3 & 4.70 & \\
\hline & \#10 & 387.0 & 54.6 & 45.4 & 1.98 & \\
\hline & $\# 20$ & 432.4 & 61.0 & 39.0 & 0.83 & \\
\hline & $\# 40$ & 472.5 & 66.7 & 33.3 & 0.42 & \\
\hline & $\# 60$ & 511.6 & 72.2 & 27.8 & 0.25 & \\
\hline & $\# 100$ & 553.3 & 78.1 & 21.9 & 0.150 & \\
\hline & $\# 200$ & 593.8 & 83.8 & 16.2 & 0.074 & \\
\hline
\end{tabular}

Sieve Analysis Data for Sample W23-20-219.5



Comments: Silty Sandy Gravel

All data are accurately and completely recorded Checked By.

Date:

B.11 


\begin{tabular}{|c|c|c|c|c|c|c|}
\hline \multicolumn{7}{|c|}{ CHzWHIITHanford, Inc. } \\
\hline WELL NAME & 299-W23-20 & DEPTH & $236.0^{\prime}-237.5^{\top}$ & SAMPLE\# & W23-20-236 & WELL ID\# \\
\hline TESTEDBY & JMW & CONTACT & Dave Weekes & PHONE & $372-9524$ & $08 / 02 / 2000$ \\
\hline $\begin{array}{l}\text { SAMPLE } \\
\text { WT (g) }\end{array}$ & $\begin{array}{c}\text { SIEVE } \\
\text { SZE IN. }\end{array}$ & $\begin{array}{l}\text { CUMULATME } \\
\text { WEIGHT(g) }\end{array}$ & $\begin{array}{c}\% \text { WEIGHT } \\
\text { RETANED }\end{array}$ & $\begin{array}{c}\% \\
\text { PASSING }\end{array}$ & $\begin{array}{c}\text { Grain Size } \\
(\mathrm{mm})\end{array}$ & COMMENTS \\
\hline 874.40 & $2^{n}$ & 0.0 & 0.0 & 100.0 & 50.80 & \\
\hline & $1.5^{n}$ & 0.0 & 0.0 & 100.0 & 38.10 & \\
\hline & $3 / 4^{\prime \prime}$ & 0.0 & 0.0 & 100.0 & 19.05 & \\
\hline & $3 / 8 "$ & 192.1 & 22.0 & 78.0 & 9.42 & \\
\hline & $\# 4$ & 334.0 & 38.2 & 61.8 & 4.70 & \\
\hline & $\# 10$ & 448.6 & 51.3 & 48.7 & 1.98 & \\
\hline & \#20 & 532.4 & 60.9 & 39.1 & 0.83 & \\
\hline & $\# 40$ & 634.5 & 72.6 & 27.4 & 0.42 & \\
\hline & $\# 60$ & 689.2 & 78.8 & 21.2 & 0.25 & \\
\hline & $\# 100$ & 732.8 & 83.8 & 16.2 & 0.150 & \\
\hline & $\# 200$ & 774.3 & 88.6 & 11.4 & 0.074 & \\
\hline
\end{tabular}

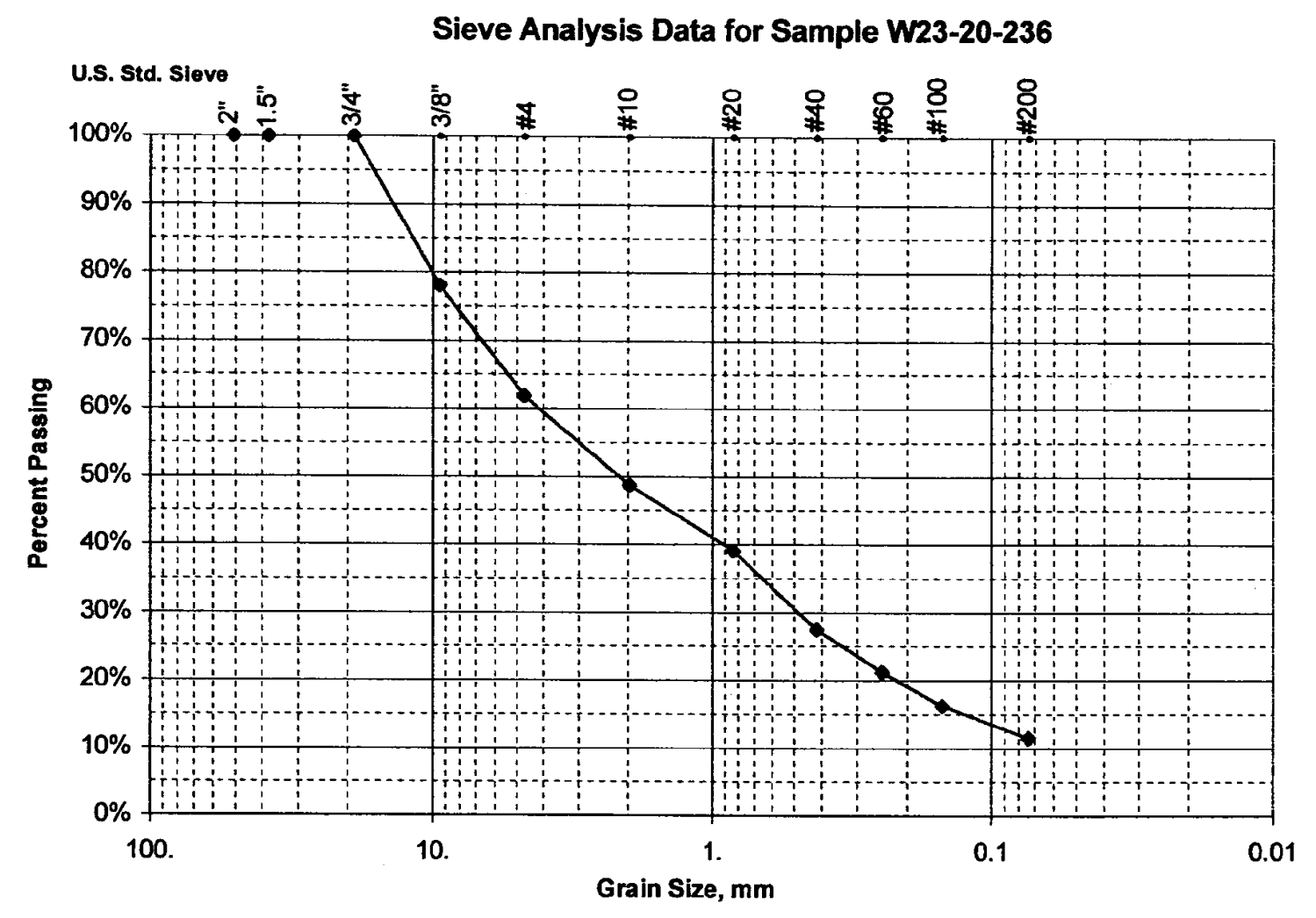

Comments: Silty Sandy Gravel

All data are accurately and completely recorded. Checked By. Date:

B. 12 


\begin{tabular}{|c|c|c|c|c|c|c|}
\hline \multicolumn{7}{|c|}{ CH2L Hili Hantord, Inc. } \\
\hline WELL NAME & $299-w 23-20$ & DEPTH & $250.1^{\prime}-252.6^{\prime \prime}$ & SAMPLE\# & W23-20-250.1 & WELL ID\# \\
\hline TESTED BY & JMW & CONTACT & Dave Weekes & PHONE & $372-9524$ & $08 / 03 / 2000$ \\
\hline $\begin{array}{l}\text { SAMPLE } \\
\text { WT (g) }\end{array}$ & $\begin{array}{c}\text { SIEVE } \\
\text { SIZE IN. }\end{array}$ & $\begin{array}{l}\text { CUMULATIVE } \\
\text { WEIGHT(g) }\end{array}$ & $\begin{array}{l}\text { \% WEIGHT } \\
\text { RETANED }\end{array}$ & $\begin{array}{c}\% \\
\text { PASSING }\end{array}$ & $\begin{array}{c}\text { Grain Size } \\
\text { (mm) }\end{array}$ & COMMENTS \\
\hline 972.50 & $2^{\prime \prime}$ & 0.0 & 0.0 & 100.0 & 50.80 & \\
\hline & $1.5^{n}$ & 0.0 & 0.0 & 100.0 & 38.10 & \\
\hline & $3 / 4^{\prime \prime}$ & 185.3 & 19.1 & 80.9 & 19.05 & \\
\hline & $3 / 8^{\prime \prime}$ & 500.5 & 51.5 & 48.5 & 9.42 & \\
\hline & $\# 4$ & 562.2 & 57.8 & 42.2 & 4.70 & \\
\hline & \#10 & 600.3 & 61.7 & 38.3 & 1.98 & \\
\hline & $\# 20$ & 626.9 & 64.5 & 35.5 & 0.83 & \\
\hline & $\# 40$ & 732.0 & 75.3 & 24.7 & 0.42 & \\
\hline & $\# 60$ & 851.8 & 87.6 & 12.4 & 0.25 & \\
\hline & $\# 100$ & 888.1 & 91.3 & 8.7 & 0.150 & \\
\hline & $\# 200$ & 913.6 & 93.9 & 6.1 & 0.074 & \\
\hline
\end{tabular}

Sieve Analysis Data for Sample W23-20-250.1

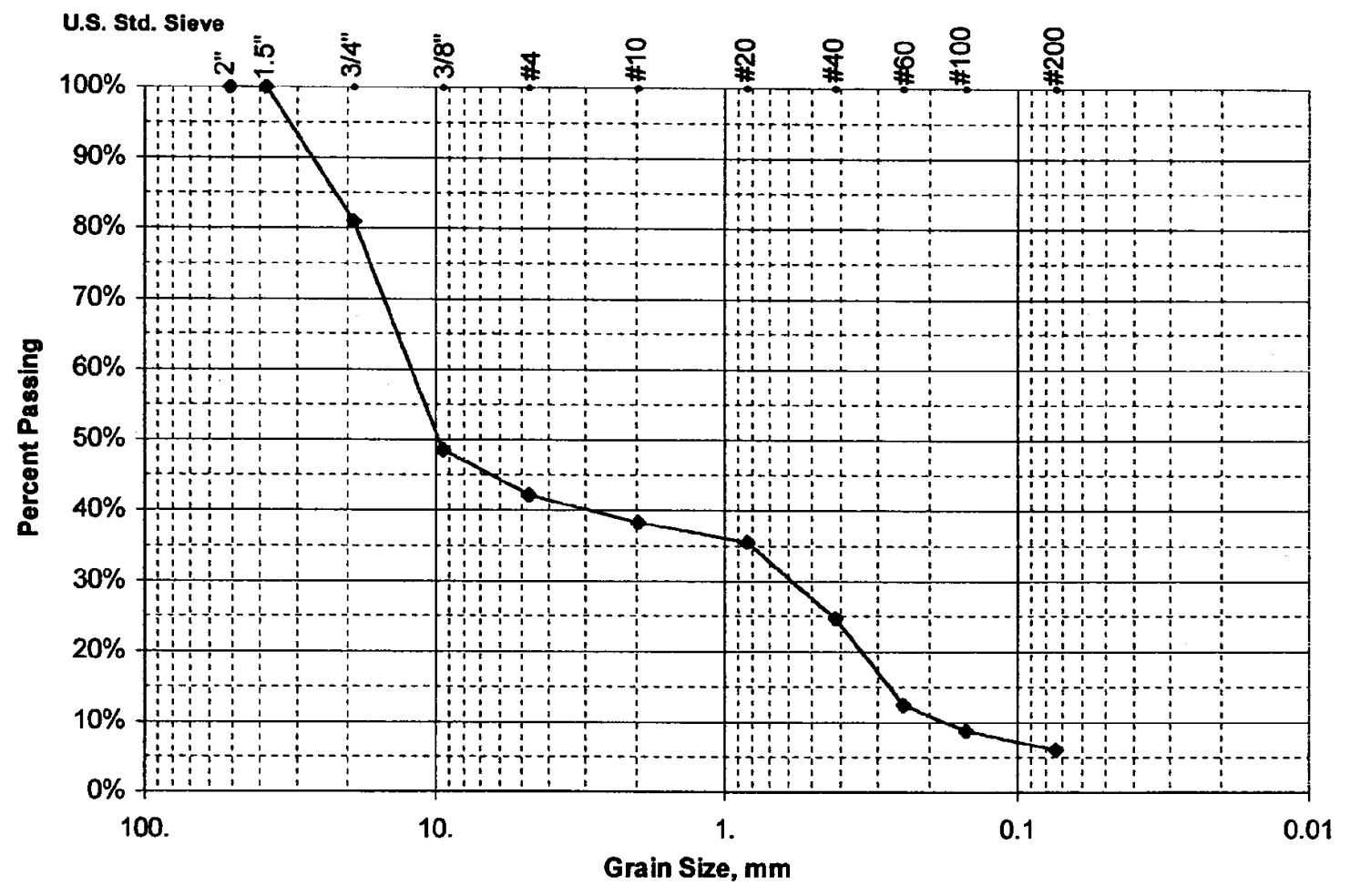

Comments: Sandy Gravel

All data are accurateby and completely recorded. Checked By:

Date:

B.13 


\begin{tabular}{|c|c|c|c|c|c|c|}
\hline \multicolumn{7}{|c|}{$\begin{array}{c}\text { CH2IM HIII Hanford, Inc. } \\
\text { SIEVE ANALYSIS }\end{array}$} \\
\hline WELL NAME & $299-W 23-21$ & DEPTH & $217.0^{\prime}-219.5^{\prime}$ & SAMPLE\# & W23-21-217.0 & WELL ID\# \\
\hline TESTED BY & JMW & CONTACT & Dave Weekes & PHONE & $372-9524$ & DATE $\quad 11 / 09 / 2000$ \\
\hline $\begin{array}{l}\text { SAMPLE } \\
W T(g)\end{array}$ & $\begin{array}{c}\text { SIEVE } \\
\text { SIZE IN. } \\
\end{array}$ & $\begin{array}{l}\text { CUMULATIVE } \\
\text { WEIGHT(g) }\end{array}$ & $\begin{array}{l}\% \text { WEIGHT } \\
\text { RETAINED }\end{array}$ & $\begin{array}{c}\% \\
\text { PASSING } \\
\end{array}$ & $\begin{array}{c}\text { Grain Size } \\
(\mathrm{mm})\end{array}$ & COMMENTS \\
\hline 949.60 & $2^{\prime \prime}$ & 0.0 & 0.0 & 100.0 & 50.80 & \\
\hline & $1.5^{\prime \prime}$ & 0.0 & 0.0 & 100.0 & 38.10 & \\
\hline & 3/4" & 64.1 & 6.8 & 93.2 & 19.05 & \\
\hline & 3/8" & 221.1 & 23.3 & 76.7 & 9.42 & \\
\hline & \#4 & 344.4 & 36.3 & 63.7 & 4.70 & \\
\hline & \#10 & 474.4 & 50.0 & 50.0 & 1.98 & \\
\hline & \#20 & 585.9 & 61.7 & 38.3 & 0.83 & \\
\hline & $\# 40$ & 651.3 & 68.6 & 31.4 & 0.42 & \\
\hline & \#60 & 718.3 & 75.6 & 24.4 & 0.25 & \\
\hline & $\# 100$ & 794.6 & 83.7 & 16.3 & 0.150 & \\
\hline & $\# 200$ & 856.9 & 90.2 & 9.8 & 0.074 & \\
\hline
\end{tabular}

Sieve Analysis Data for Sample W23-21-217.0

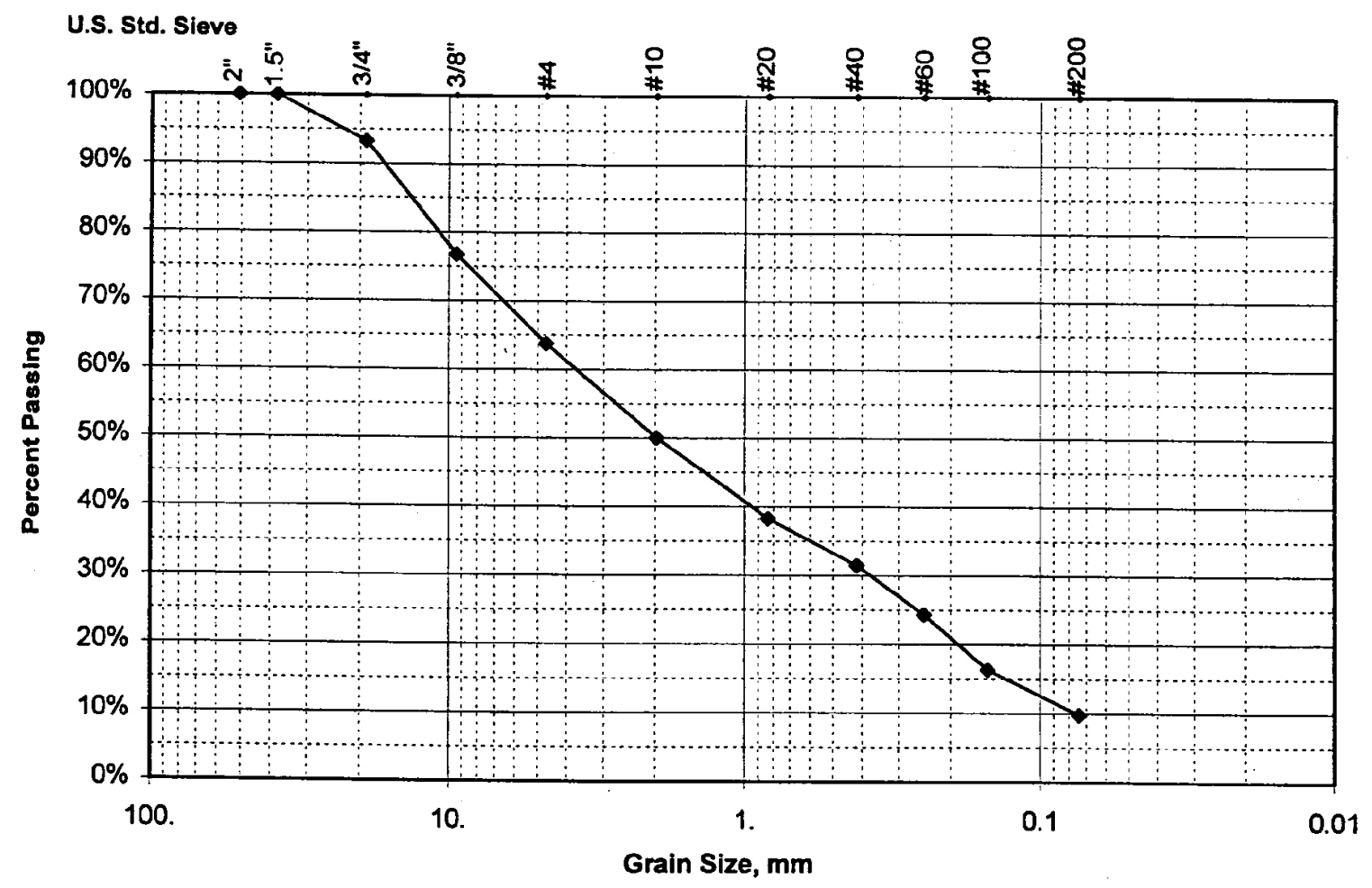

Comments: $d \mathrm{~J}_{\text {silly }}$ Sandy Gravel

All data are accurate $y$ and completely recorded.

Checked By: DCPleerex

Date: $11 / 14 / 00$

B. 14 


\begin{tabular}{|c|c|c|c|c|c|c|}
\hline \multicolumn{7}{|c|}{ CH2M Hill Hanford, Inc. } \\
\hline \multirow{2}{*}{\begin{tabular}{|l} 
WELL NAME \\
TESTED BY \\
\end{tabular}} & 299-W23-21 & DEPTH & $232.0^{\prime}-234.0^{\prime}$ & SAMPLE\# & W23-21-232.0 & WELL ID\# \\
\hline & JMW & CONTACT & Dave Weekes & PHONE & $372-9524$ & DATE $\quad 11 / 09 / 2000$ \\
\hline $\begin{array}{l}\text { SAMPLE } \\
\text { WT (g) } \\
\end{array}$ & $\begin{array}{c}\text { SIEVE } \\
\text { SIZE IN. }\end{array}$ & $\begin{array}{l}\text { CUMULATIVE } \\
\text { WEIGHT(g) }\end{array}$ & $\begin{array}{l}\% \text { WEIGHT } \\
\text { RETAINED }\end{array}$ & $\begin{array}{c}\% \\
\text { PASSING } \\
\end{array}$ & $\begin{array}{c}\begin{array}{c}\text { Grain Size } \\
(\mathrm{mm})\end{array} \\
\end{array}$ & COMMENTS \\
\hline 982.80 & $2 "$ & 0.0 & 0.0 & 100.0 & 50.80 & \\
\hline & 1.5 & 0.0 & 0.0 & 100.0 & 38.10 & \\
\hline & $3 / 4 "$ & 127.9 & 13.0 & 87.0 & 19.05 & \\
\hline & $3 / 8$ & 237.9 & 24.2 & 75.8 & 9.42 & \\
\hline & $\# 4$ & 329.4 & 33.5 & 66.5 & 4.70 & \\
\hline & $\# 10$ & 452.5 & 46.0 & 54.0 & 1.98 & \\
\hline & $\# 20$ & 549.9 & 56.0 & 44.0 & 0.83 & \\
\hline & \#40 & 607.6 & 61.8 & 38.2 & 0.42 & \\
\hline & $\# 60$ & 698.0 & 71.0 & 29.0 & 0.25 & \\
\hline & $\# 100$ & 763.9 & 77.7 & 22.3 & 0.150 & \\
\hline & \#200 & 823.1 & 83.8 & 16.2 & 0.074 & \\
\hline
\end{tabular}

Sieve Analysis Data for Sample W23-21-232.0

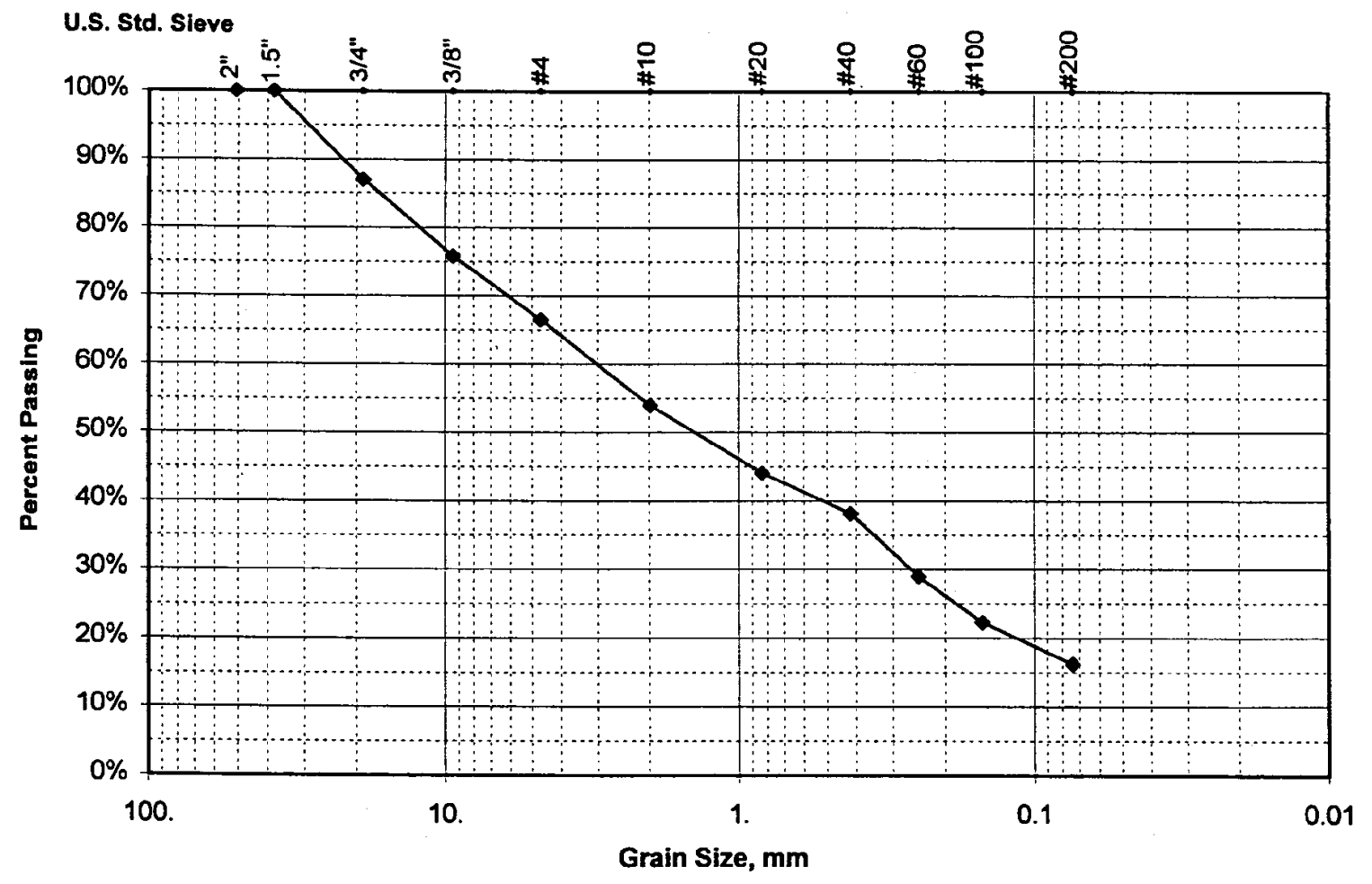



B. 15 


\begin{tabular}{|c|c|c|c|c|c|c|}
\hline \multicolumn{7}{|c|}{ CH2M Hill Hanford, Inc. } \\
\hline \multirow{2}{*}{\begin{tabular}{|l} 
WELL NAME \\
TESTED BY \\
\end{tabular}} & 299-W23-21 & DEPTH & $247.5^{\prime}-248.5^{\prime}$ & SAMPLE\# & \multicolumn{2}{|c|}{\begin{tabular}{l|l|l|} 
W23-21-247.5 & WELL ID\# & C3113 \\
\end{tabular}} \\
\hline & JMW & CONTACT & Dave Weekes & PHONE & $372-9524$ & $11 / 09 / 2000$ \\
\hline $\begin{array}{l}\text { SAMPLE } \\
\text { WT (g) }\end{array}$ & $\begin{array}{c}\text { SIEVE } \\
\text { SIZE IN. }\end{array}$ & $\begin{array}{c}\text { CUMULATIVE } \\
\text { WEIGHT(g) } \\
\end{array}$ & $\begin{array}{l}\% \text { WEIGHT } \\
\text { RETAINED }\end{array}$ & $\begin{array}{c}\% \\
\text { PASSING } \\
\end{array}$ & $\begin{array}{c}\text { Grain Size } \\
(\mathrm{mm})\end{array}$ & COMMENTS \\
\hline 981.20 & $2 "$ & 0.0 & 0.0 & 100.0 & 50.80 & \\
\hline & $1.5^{\prime \prime}$ & 0.0 & 0.0 & 100.0 & 38.10 & \\
\hline & $3 / 4^{\prime \prime}$ & 100.3 & 10.2 & 89.8 & 19.05 & \\
\hline & $3 / 8^{\prime \prime}$ & 287.8 & 29.3 & 70.7 & 9.42 & \\
\hline & $\# 4$ & 388.9 & 39.6 & 60.4 & 4.70 & \\
\hline & $\# 10$ & 477.1 & 48.6 & 51.4 & 1.98 & \\
\hline & $\# 20$ & 554.7 & 56.5 & 43.5 & 0.83 & \\
\hline & $\# 40$ & 621.2 & 63.3 & 36.7 & 0.42 & \\
\hline & $\# 60$ & 712.3 & 72.6 & 27.4 & 0.25 & \\
\hline & $\# 100$ & 805.5 & 82.1 & 17.9 & 0.150 & \\
\hline & $\# 200$ & 875.5 & 89.2 & 10.8 & 0.074 & \\
\hline
\end{tabular}

\section{Sieve Analysis Data for Sample W23-21-247.5}

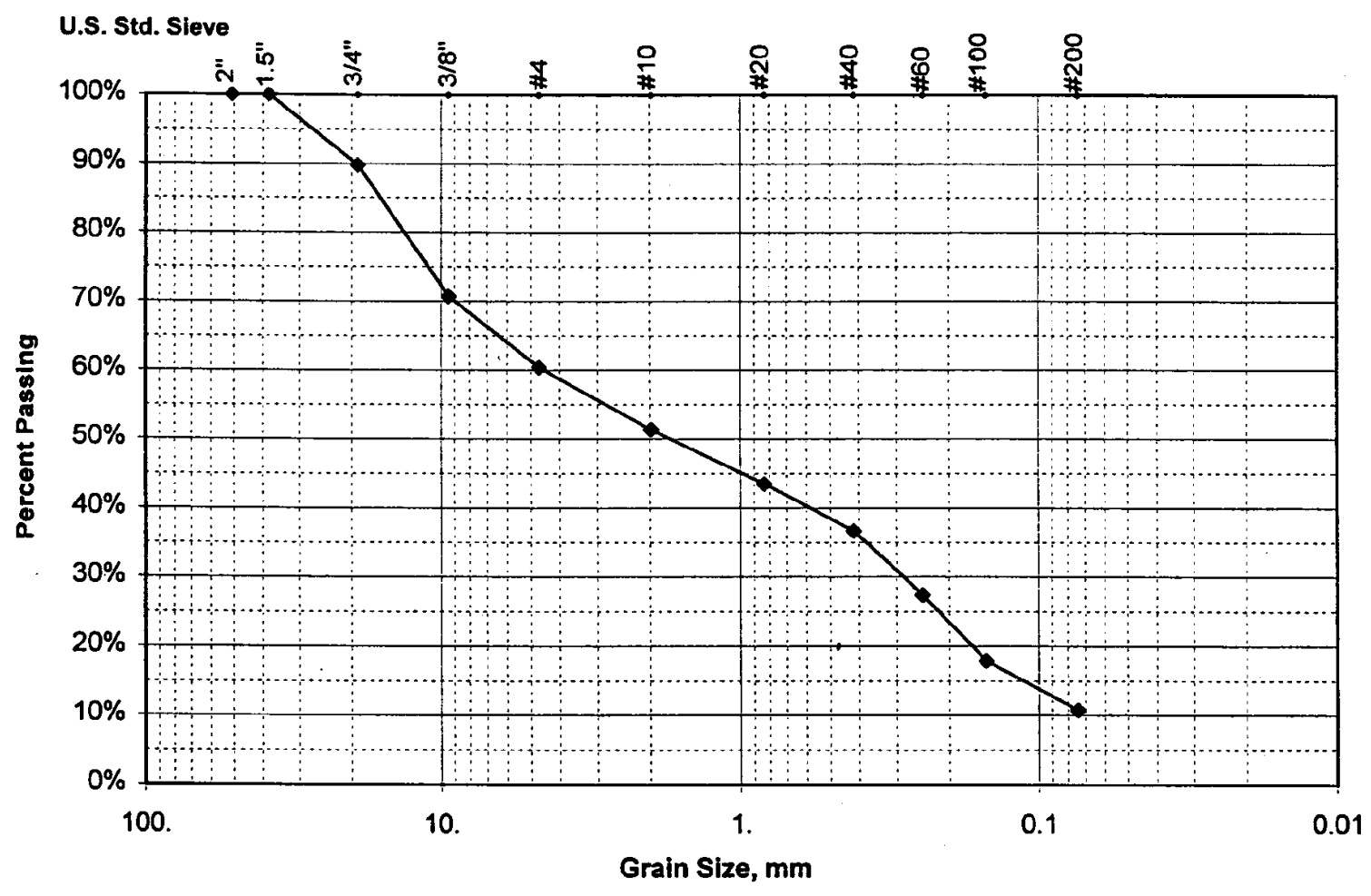

Comments: Siltygandy Gravel

All data are accura ly and completely recorded. Checked By: Jacleetere Date: $11 / 14 / 00$

B.16 


\section{Appendix C}

\section{Borehole Geophysical Logs}




\section{Appendix C}

\section{Borehole Geophysical Logs}

This appendix contains the borehole geophysical logs obtained from boreholes 299-W22-81, 299-W22-83, 299-W22-83, and 299-W23-21. The logs were run and analyzed by Duratek, Waste Management Federal Services Northwest, Inc. and MacTec Inc. Log Header sheets and Log Analysis Summary Reports are included with the logs. 


\section{Log Data Report 299-W22-81}

\section{Borehole Information}

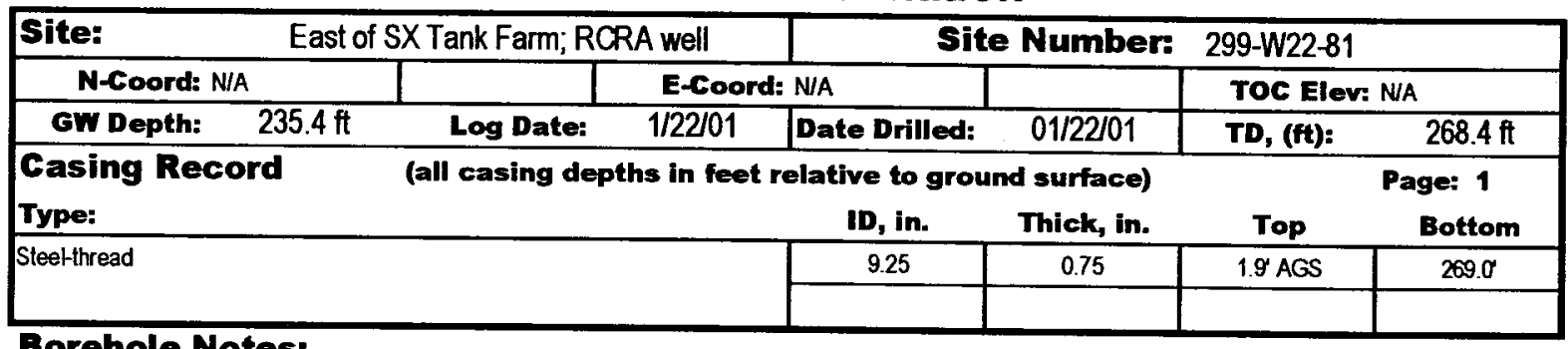

\section{Borehole Notes:}

Borehole 299-W22-81 (C3123) was drilled in January 2001 to a total depth of $268.4 \mathrm{ft}$. A cable-tool drilling rig was used to install the borehole. Single casing was present from $1.9 \mathrm{ft}$ above ground surface to a total depth of $269.0 \mathrm{ft}$ and was comprised of 9.25-in.-diameter, 0.75 -in.-thick threaded steel. At the time analysis was performed, the borehole coordinates and ground surface elevation were not available. The zero reference for all log depths is the ground surface. The depth to water reported by the well site geologist was $226.3 \mathrm{ft}$, but the measurements from the neutron logging suggest the depth to water was at apdroximatelv $235.4 \mathrm{ft}$ at the time of looaina.

Equipment Information

\begin{tabular}{|c|c|c|c|c|c|c|}
\hline Log System: & $2 \mathrm{~B}$ & & Type: & HPGe & Efficlency: & $35 \%$ \\
\hline Cal Date: & Feb-00 & Cal Ref: & GJO-HAN-30 & & Log Proc: & MAC-VZCP 1.7.10-1, Rev 3 \\
\hline
\end{tabular}

\section{Logging Information}

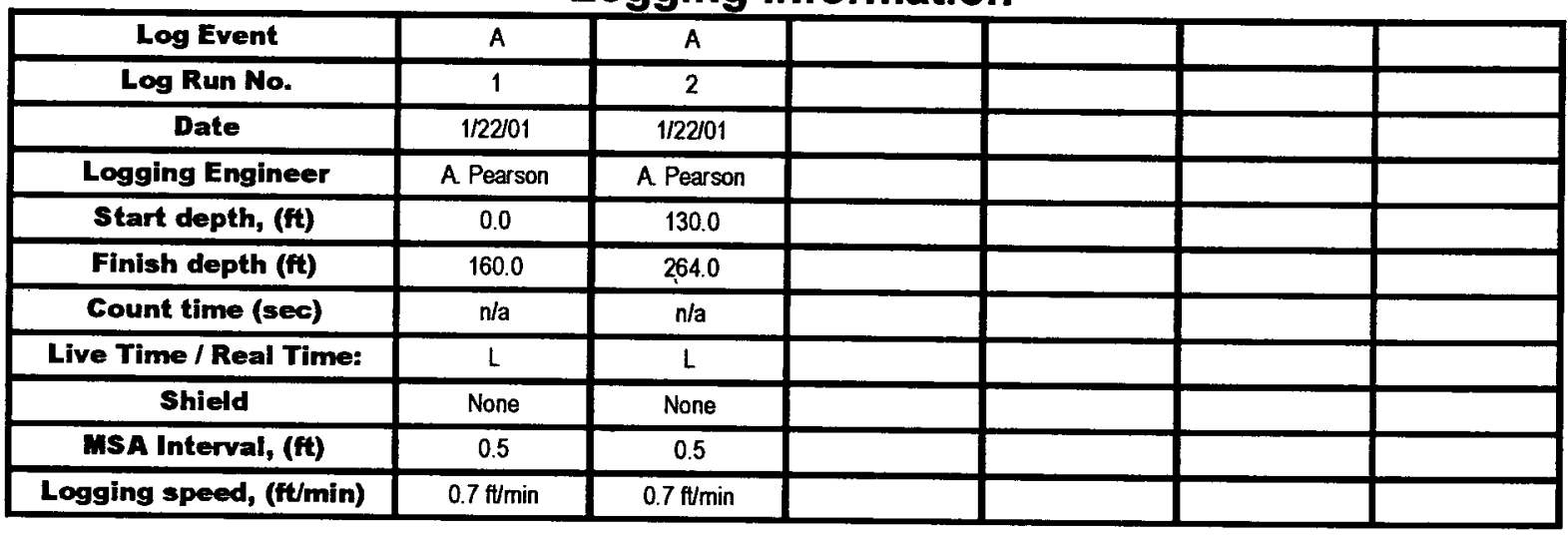

\section{Logging Operation Notes:}

Logging operations were performed by MACTEC-ERS under contract with Duratek Federal Services, who also specitied the logging parameters. This borehole was logged with the MACTECERS Spectral Gamma Logging System (SGLS) in two log runs to a total depth of $264 \mathrm{ft}$. Details for the SGLS logging events and log runs are presented in the Logging Information section of this report. Neutron logging events are not recorded in this Log Data Report.

Log run two $(130-264 \mathrm{ft})$ overlaps part of log run one $(0-160 \mathrm{ft})$ and defines the repeat interval $(130-160 \mathrm{ft})$ for the SGS survey. The reneat lon nun was berformed to check for deoth and concentration reoeatabilitv 


\section{Log Data Report \\ 299-W22-81}

\section{Analysis Information}

\begin{tabular}{|c|c|}
\hline R. Spatz, R. McCain & Date: \\
\hline Analysis Ref: MAC-VZCP 1.7.9, Rev. 2 & Page: \\
\hline
\end{tabular}

Log analysis was performed by MACTECERS under contract with Duratek Federal Services. The pre-and post-survey field verification spectra met the acceptance criteria established for peak shape and detector efficiency. The energy calibration and peak-shape calibration from these spectra were used in processing the log spectra. Dead time was less than $10 \%$ throughout the borehole and no dead time corrections were applied. Repeat logging intervals were collected at the depths shown in the combination plot. Excellent repeatability is shown, confirming an acceptable performance of the logging systems.

A casing correction factor for 0.75 -in.-thick steel casing was applied to the data between depths of 0 and $264 \mathrm{ft}$. A water correction factor was also applied to spectral data collected below the depth of $235.4 \mathrm{ft}$. At the time of logging, grout was not present around the borehole.

Gamma-ray photon peaks associated with specific energies were used to calculate concentrations in picocuries per gram (pCig) for naturally occurring radionuclides potassium-40 (K-40), uranium-238 (U-238), and thorium-232 (Th-232) (KUT), with gammaray energies of $1460.8,609.3$, and $2614.5 \mathrm{keV}$, respectively.

Shorter than optimal system counting time $(0.7 \mathrm{ft} / \mathrm{min})$ for relatively thick casing $(0.75$-in.-thick $)$ is the cause of the intermittent detection of U-238 (609.3 keV).

Spectral data analysis at the 85.75 - and 165.75 -ft depths, using the routine processing software, calculated two very low concentrations of Cs-137. Review of the spectra shows high counting errors; therefore, the peaks are not considered statistically valid. In the absence of additional $C_{s-137}$ being detected from above or below these intervals, the existence of the cs-137 could not be corroborated and was removed from the loo nlots

Higher than average KUT concentrations below the depth of $256 \mathrm{ft}$ may be attributed to a lithology change, or the absence of casing, which caused the concentrations to be overestimated at this depth.

Neutron data acquired with the SGLS using Duratek Federal Services' neutron moisture sonde are presented in neutron count rate instead of percent volumetric moisture. because this tool is not calibrated on the SGLS.

\section{Log Plot Notes:}

Separate log plots are provided for total gamma, total neutron, and naturally occurring radionuclides (KUT). A plot of the total neutron count rate is provided on the combination plot as well as on several plots showing total gamma and total neutron count rates.

\section{Results / Interpretations:}

Borehole 299-W22-81 was logged with the SGLS on January 22, 2001. A neutron and spectral gamma survey were both conducted in this borehole and recorded as $\log$ Events $A$ and $B$, respectively.

Man-made contaminants were not detected by the SGLS survey. Naturally occurring U-238 and Th-232 concentrations increase between 130 and $140 \mathrm{ft}$, and KUT concentrations increase between 142 and $160 \mathrm{ft}$, which may indicate lithology changes. The total gamma count rate correlates at those depths where KUT concentrations increase. Neutron logging detected ground water at the 235.4-ft depth. 


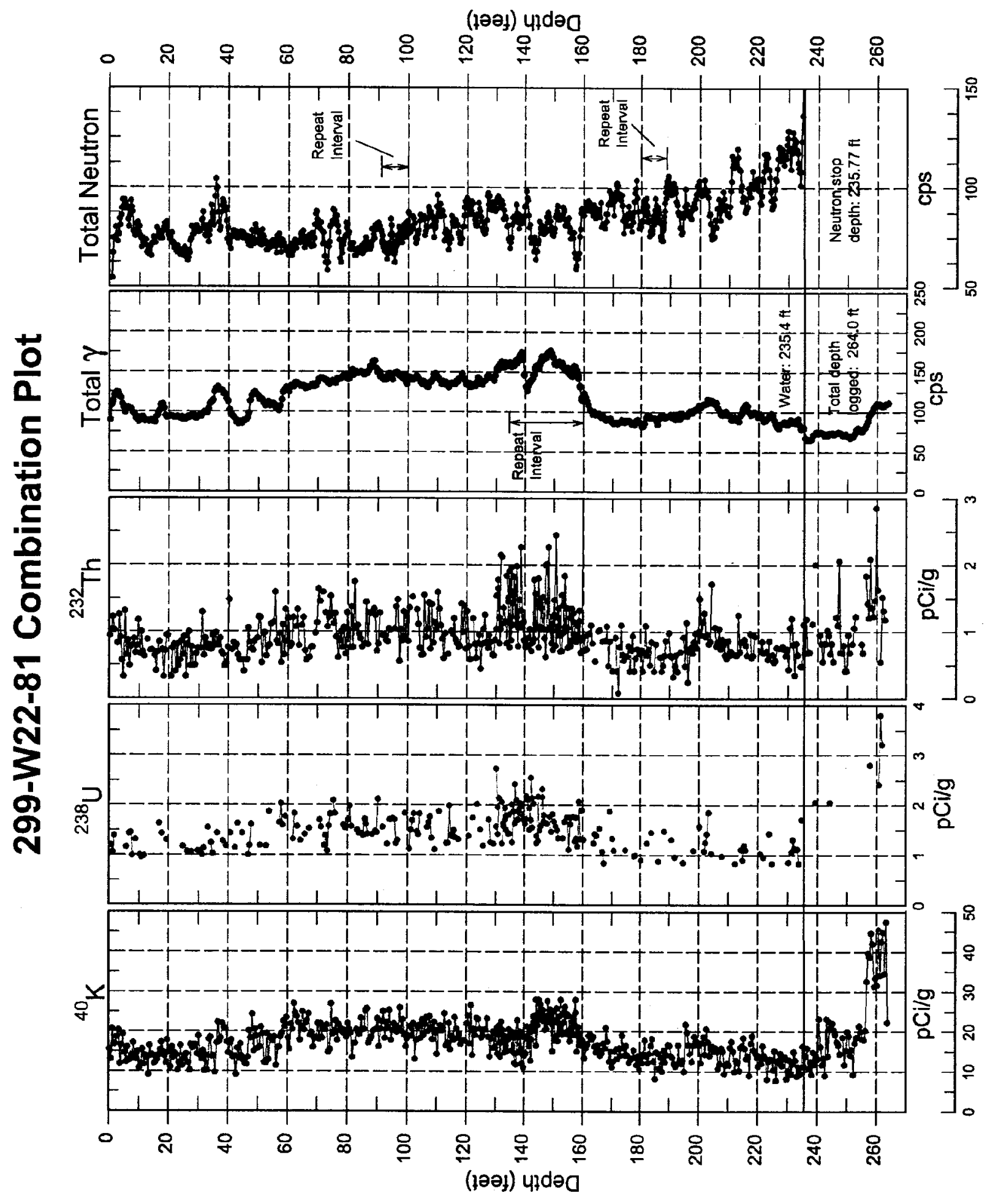

C. 4 


\section{Spectral Gamma Survey \\ Duratek Federal Services}

Project: RCRA Well

Well: 299-W22-81
Log Date: January 22, 2001

Depth Datum: Ground Level
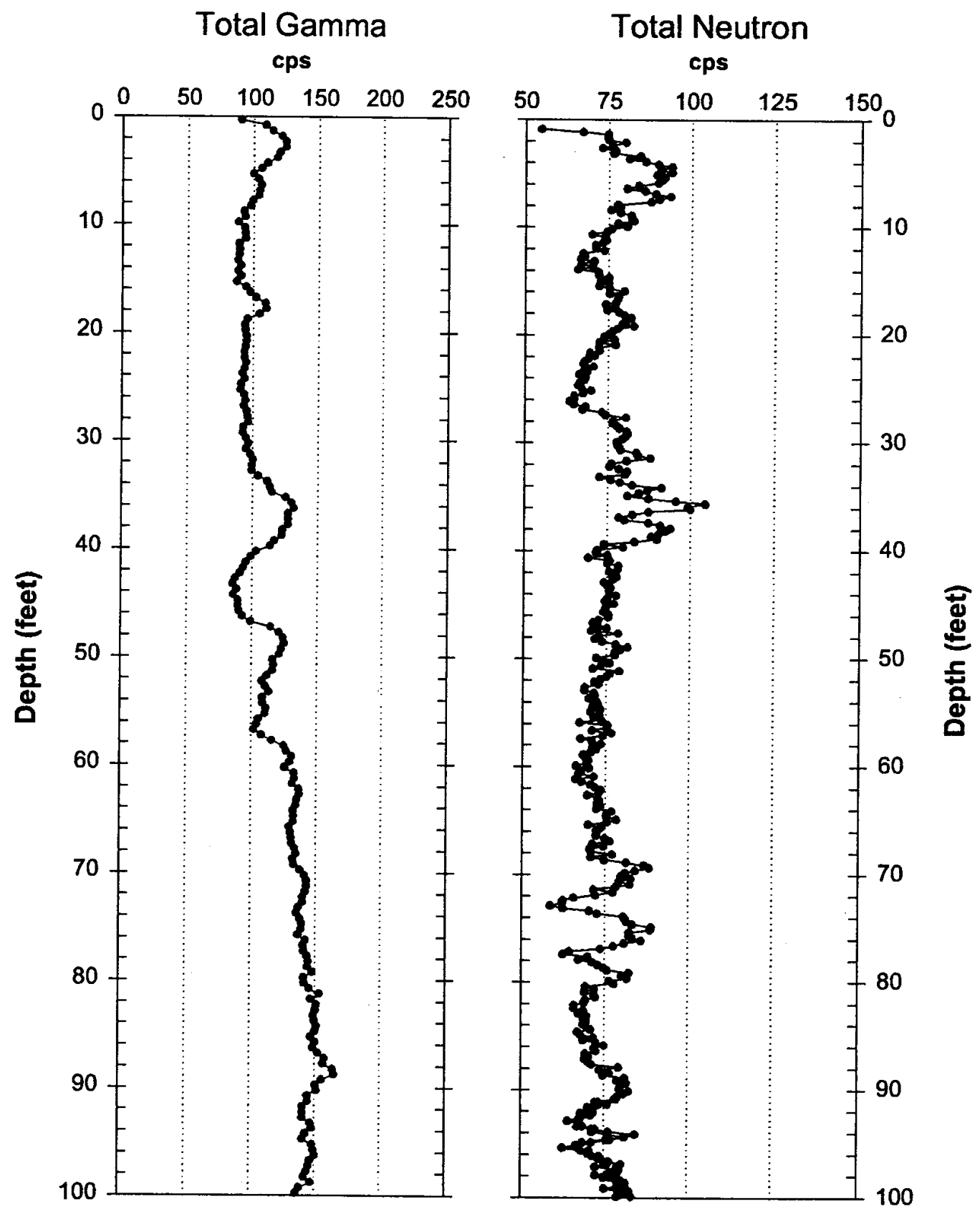

C.5 


\section{Spectral Gamma Survey}

\section{Duratek Federal Services}

Project: RCRA Well

Well: 299-W22-81
Log Date: January 22, 2001

Depth Datum: Ground Level
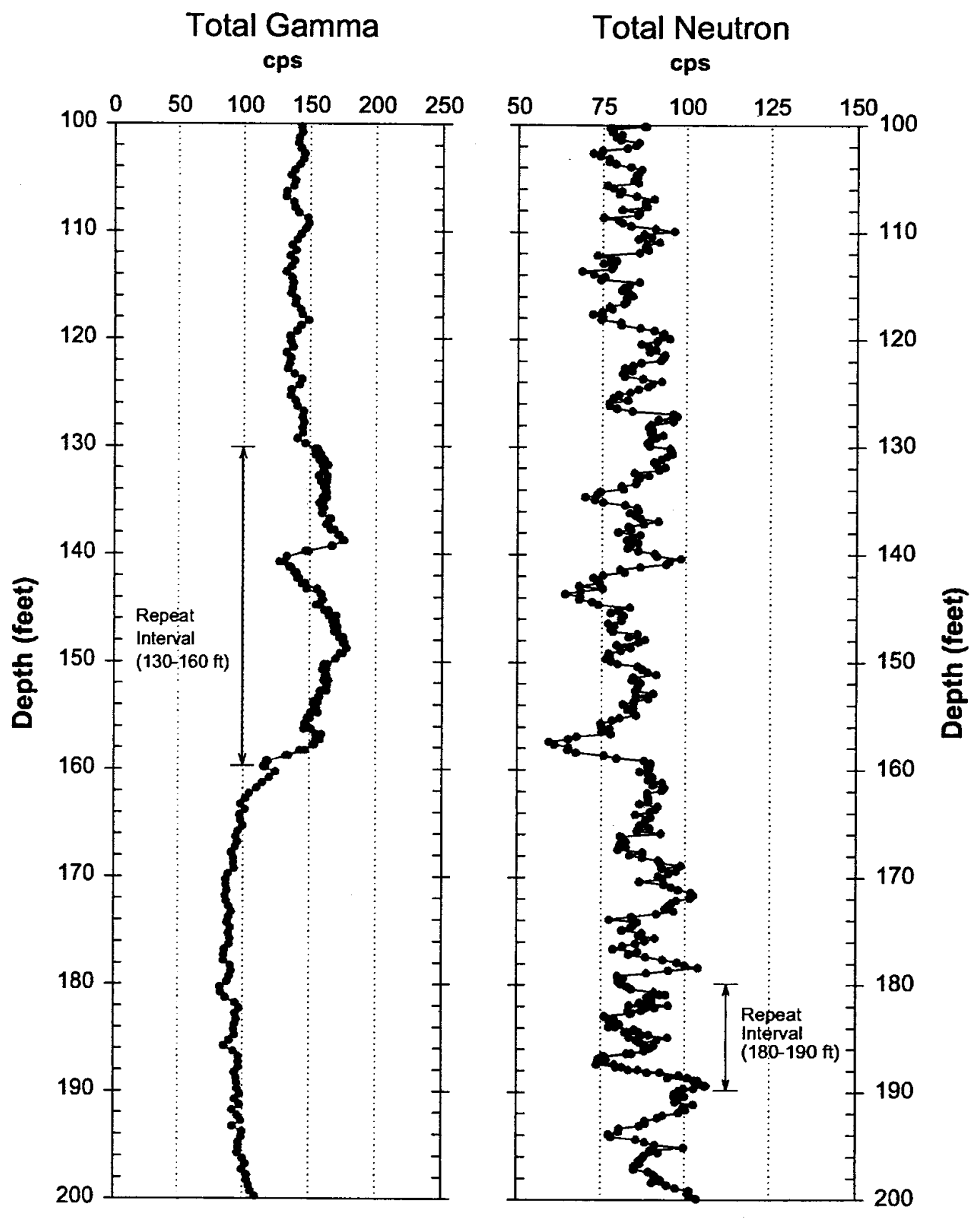

C. 6 


\section{Spectral Gamma Survey}

\section{Duratek Federal Services}

Project: RCRA Well

Well: 299-W22-81
Log Date: January 22, 2001

Depth Datum: Ground Level



C.7 


\section{Spectral Gamma Survey}

Duratek Federal Services

Project: RCRA Well Well: 299-W22-81
Log Date: January 22, 2001 Depth Datum: Ground Level

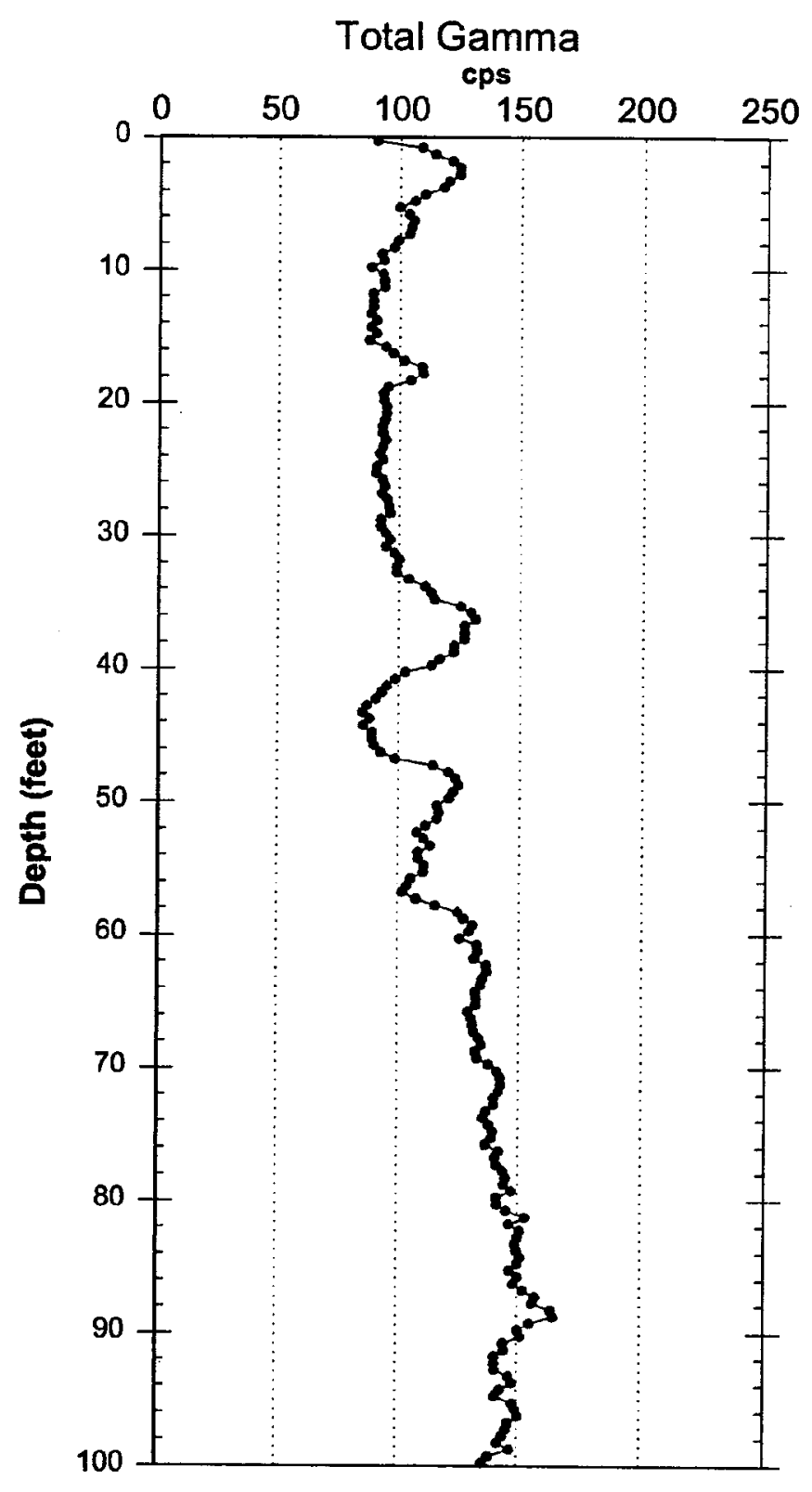

Potassium Uranium Thorium $\mathrm{pCi} / \mathrm{g}$






\section{Spectral Gamma Survey}

\section{Duratek Federal Services}

Project: RCRA Well

Well: 299-W22-81
Log Date: January 22, 2001

Depth Datum: Ground Level

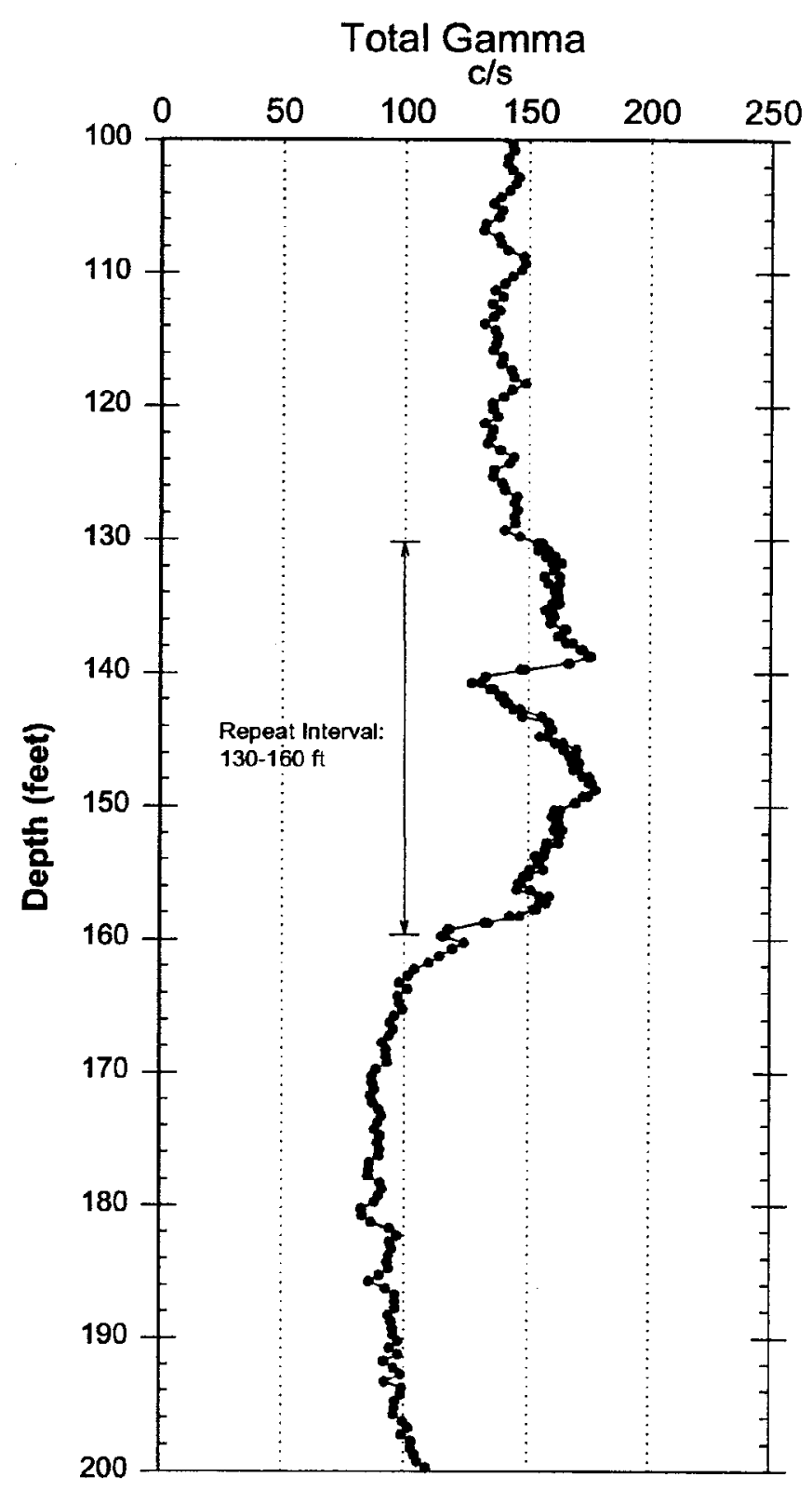

Potassium Uranium Thorium $\mathrm{pCi} / \mathrm{g} \quad \mathrm{pCi} / \mathrm{g} \quad \mathrm{pCi} / \mathrm{g}$

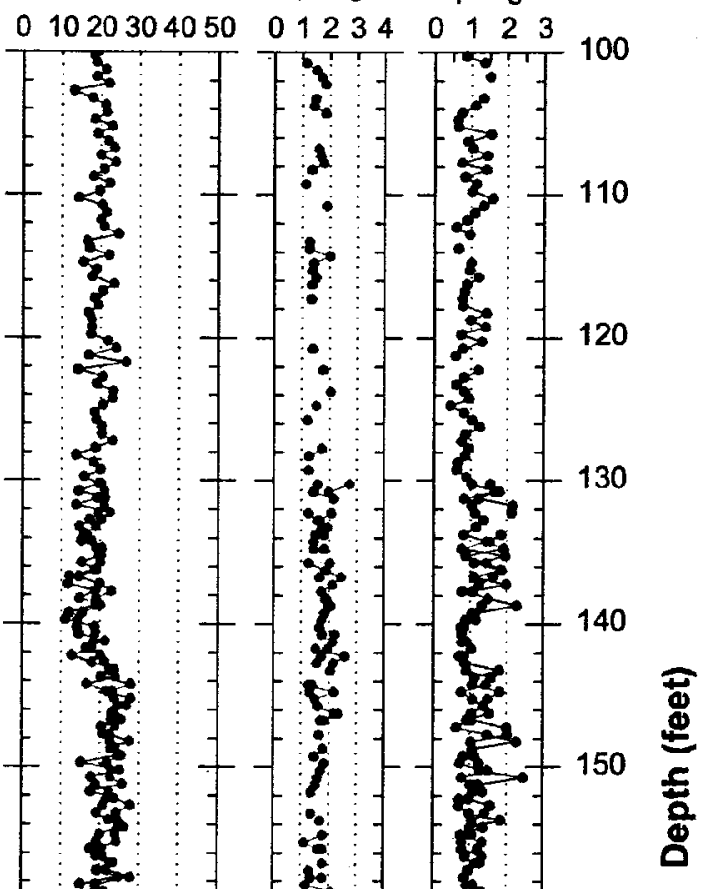




\section{Spectral Gamma Survey}

\section{Duratek Federal Services}

Project: RCRA Well

Well: 299-W22-81
Log Date: January 22, 2001

Depth Datum: Ground Level






\section{Neutron-Neutron Moisture Borehole Survey \\ Duratek Federal Services, Inc.}

\section{Log Header}

Project: $\quad 2000$ RCRA Drilling

Well: 299-W22-81

\section{Log Type: Moisture Gauge}

Borehole Information

\begin{tabular}{|c|c|c|c|}
\hline Well \# C3123 & Water Depth & $235^{*}$ & Total Depth $269 \mathrm{ft}$ \\
\hline Elevation Reference $\mathrm{n} / \mathrm{a}$ & Elevation & $\mathrm{n} / \mathrm{a}$ & \\
\hline Depth Reference Ground Surface & Casing Stickup & 1.9 & \\
\hline Casing Diameter $9.25 \mathrm{ID}$ in & Depth Interval & 0 to $269 \mathrm{ft}$ & Thickness \\
\hline
\end{tabular}

"235 ft water depth is from log response of 1-22-01, geologist's set water depth at $226 \mathrm{ft}$

\section{Logging Information}

\begin{tabular}{|c|c|c|c|}
\hline $\begin{array}{l}\text { Log Type: } \\
\text { Company }\end{array}$ & \multicolumn{3}{|c|}{$\begin{array}{l}\text { Moisture Gauge } \\
\text { Duratek Federal Services, Inc. }\end{array}$} \\
\hline Date/Archive File Name & January 22,2001 & $2 \mathrm{~W} 22 \mathrm{C}$ & 081 \\
\hline Logging Engineers & A. Pearson & & \\
\hline Instrument Series & $\overline{\text { RLSM00.0 }}$ & & \\
\hline Logging Unit & RLS-2 & & \\
\hline Depth Interval & $\begin{array}{l}0 \text { to } 100 \mathrm{ft} \\
90 \text { to } 190 \mathrm{ft} \\
180 \text { to } 236 \mathrm{ft}\end{array}$ & Prefix & $\begin{array}{l}\text { FOBA1 } \\
\text { FOBA2 } \\
\text { FOBA3 }\end{array}$ \\
\hline
\end{tabular}

Instrument Calibration Date

Calibration Report

July 14,2000

WHC-SD-EN-TI-306, Rev. 0

Analysis Information

$\begin{array}{ll}\text { Company } & \text { Three Rivers Scientific } \\ \text { Analyst } & \text { Russ Randall } \\ \text { Date } & \text { February 5, 2001 }\end{array}$

Notes Moisture values range from $3 \%$ to $21 \%$ for the depths logged. The onset of high moisture readings at 235 feet is due to the proximity of the water level in the borehole. No valid calibration is available for the 9.25 inch casing diameter from surface to 269 feet. The calibration for the 10.75 inch borehole diameter was extrapolated from standard diameter conditions, and casing correction applied to all depths logged. 


\section{Moisture Log Analysis \& Summary \\ Duratek Federal Services, Inc.}

$\begin{array}{lllr}\text { Project: } & \text { 2000 RCRA Drilling } & \text { Well ID: } & \text { 299-W22-81 } \\ \text { Log Type: } & \text { Moisture Gauge } & \text { Log Date: } & \text { January 22, 2001 }\end{array}$

\section{General Notes:}

The largest borehole diameter for the calibration models is an 8.64 inch borehole diameter, with .32 inch casing thickness, and the borehole diameter in these $\log$ data is 10.75 inches. Therefore, an extrapolation was calculated for the applied calibration coefficients to match the conditions of the logged borehole. The method of extrapolation generated conservative estimates for the moisture values (possibly lower values than a valid calibration). The size differential of this borehole from the calibration standard is at the limits of rigorous extrapolation; however, the resultant moisture values appear to be near those commonly encountered for vadose zone results at the Hanford site.

Log data collected with a depth reference of ground surface.

System Performance Verify: The pre- and post-log verification passed performance standards, $+1.3 \%$ change from start of $\log$ to end of $\log$, in the shield verify.

Repeat Interval: Based on the repeat intervals from 91 to 100 feet and 181 to 190 feet, the logging system performed according to specifications.

Environmental Corrections: The moisture levels have been corrected for casing thickness $(0.75$ inch) for all well depths logged. No formation density correction has been applied because density values are not available.

\section{Observations:}

The moisture levels show values ranging from $3 \%$ to $21 \%$ for all depth intervals logged. The abnormally high readings that begin at 235 feet are a response to the water level at 235 feet. Note that geologist's information puts the water depth at 226 feet. The date of the geologist's information is unknown, but the moisture log response puts the water depth of 235 feet on January 22, 2001. 


\title{
RLS Neutron-Neutron Moisture
}

\author{
Duratek Federal Services, Inc.
}

Project: 2000 RCRA Drilling

Borehole: 299-W22-81

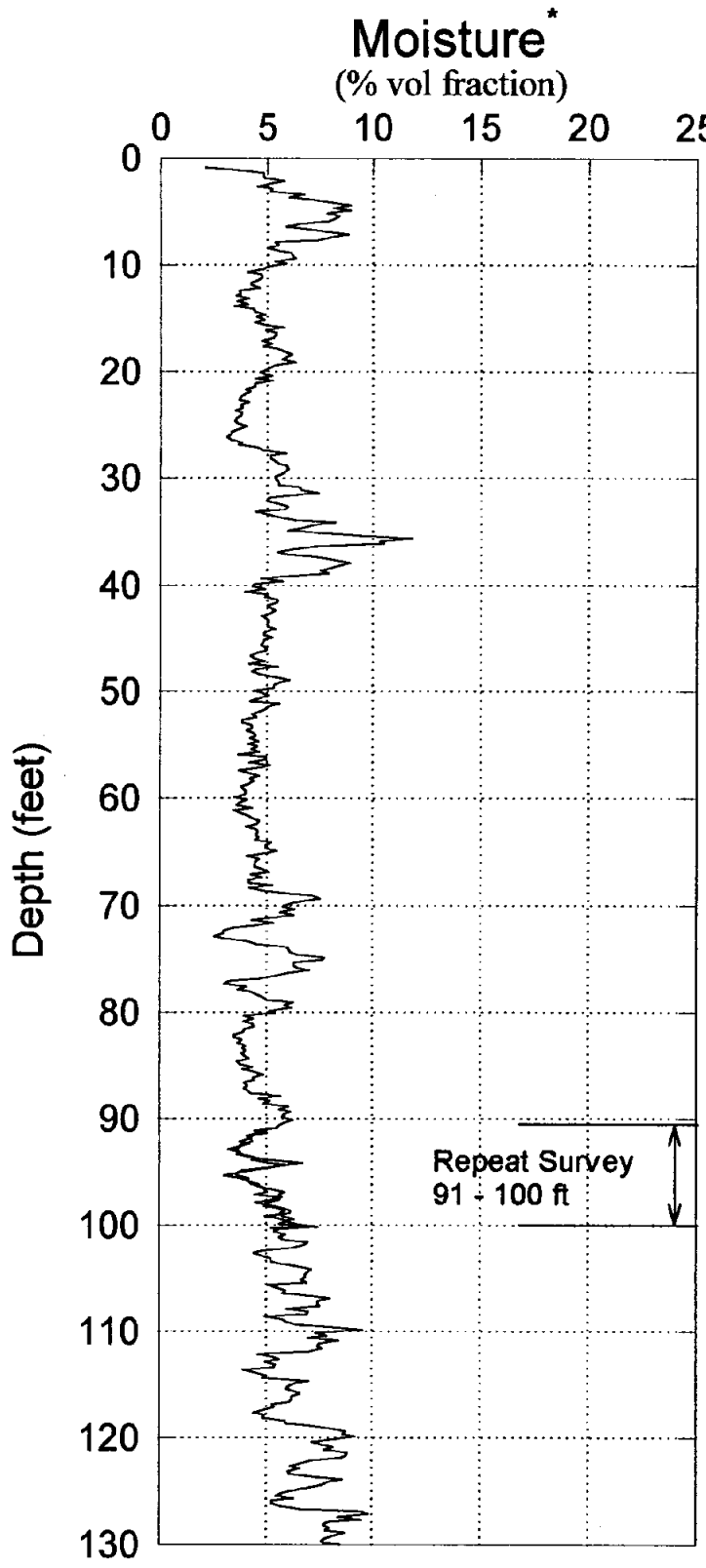

Calibration extrapolated to 10.75 inch borehole diameter Casing thickness correction for 0.75 inch Analysis by Three Rivers Scientific
Log Date : January 22, 2001

Depth Datum : Ground Surface






\section{RLS Neutron-Neutron Moisture}

\section{Duratek Federal Services, Inc.}

Project: 2000 RCRA Drilling

Borehole: 299-W22-81

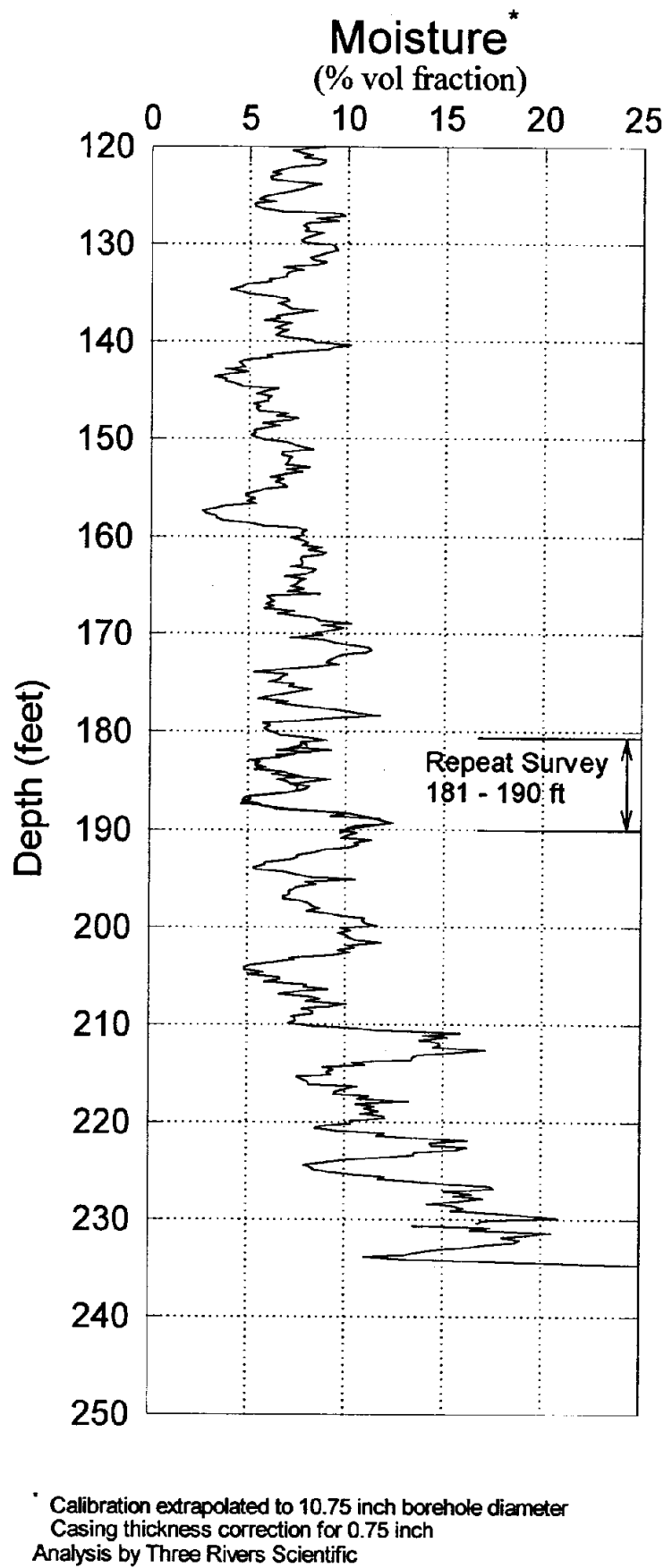

Log Date : January 22, 2001

Depth Datum : Ground Surface

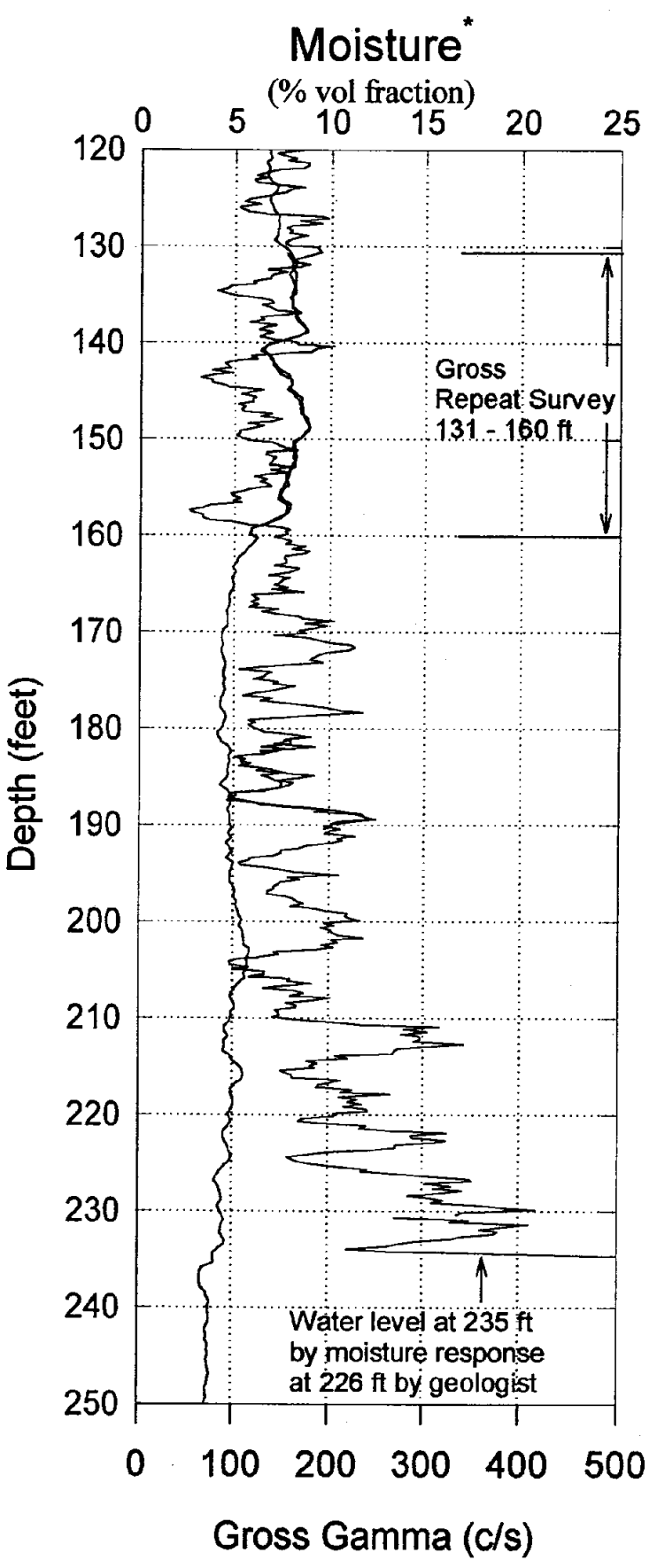




\section{Spectral Gamma \& Moisture Survey \\ Duratek Federal Services}

Project: RCRA Well

Well: 299-W22-81
Log Date: January 23 \&24, 2001

Depth Datum: Ground Level

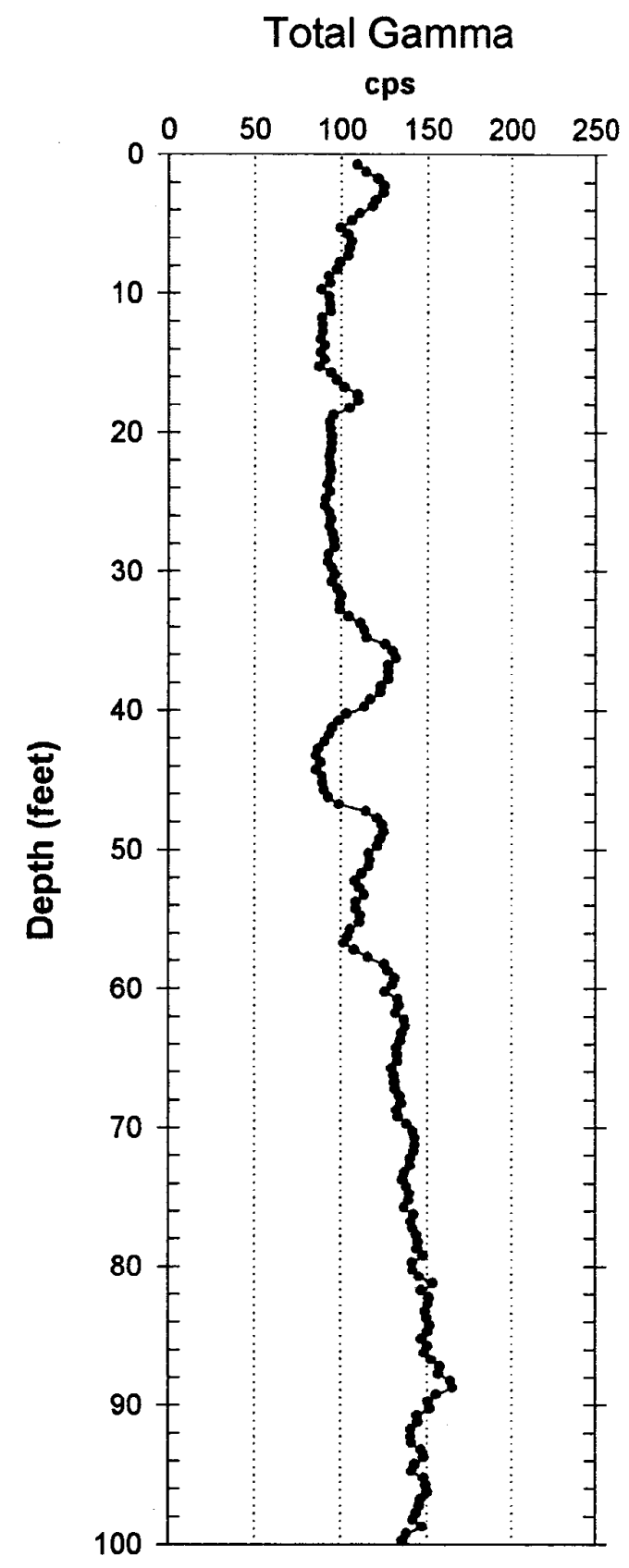

Total Neutron

cps

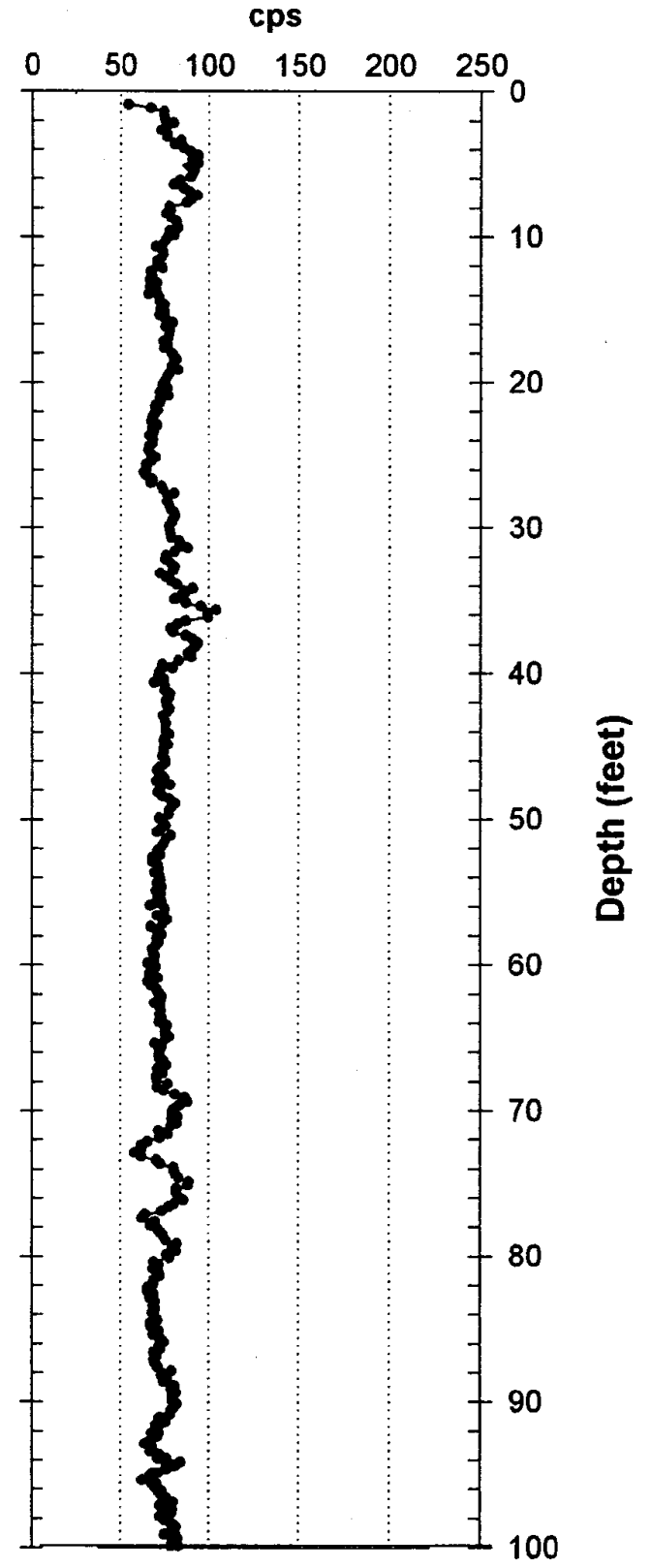

C. 15 


\section{Spectral Gamma \& Moisture Survey Duratek Federal Services}

Project: RCRA Well

Well: 299-W22-81
Log Date: January 23\&24, 2001

Depth Datum: Ground Level
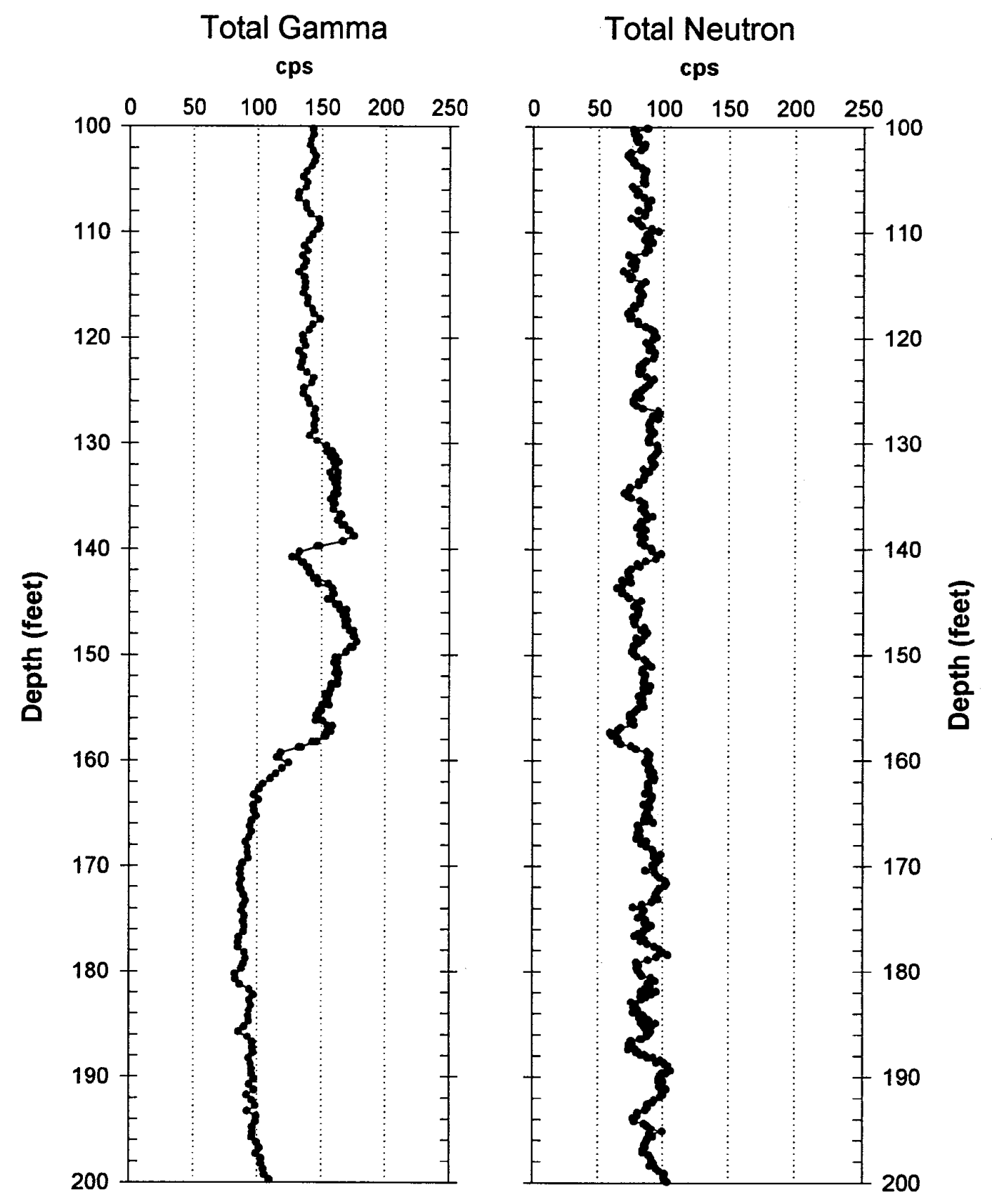

C.16 


\section{Spectral Gamma \& Moisture Survey Duratek Federal Services}

Project: RCRA Well

Well: 299-W22-81
Log Date: January 23\&24, 2001

Depth Datum: Ground Level

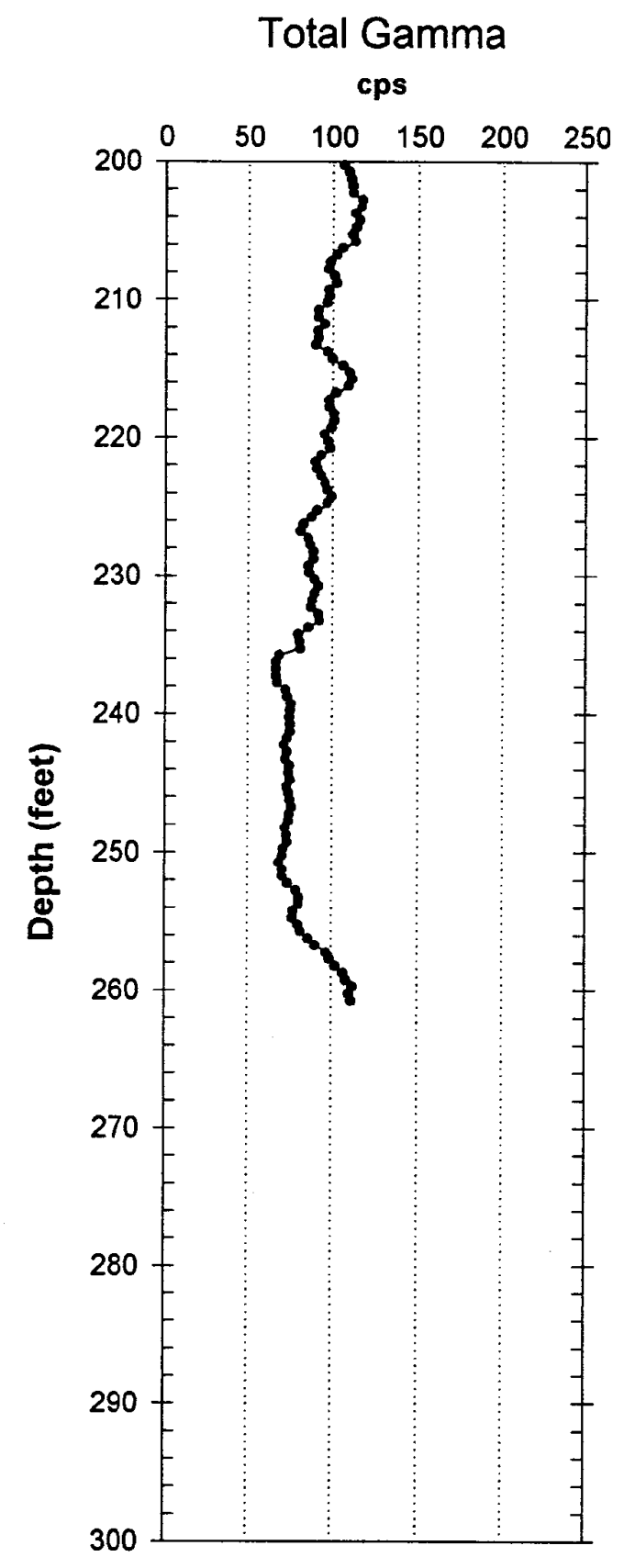

Total Neutron

cps

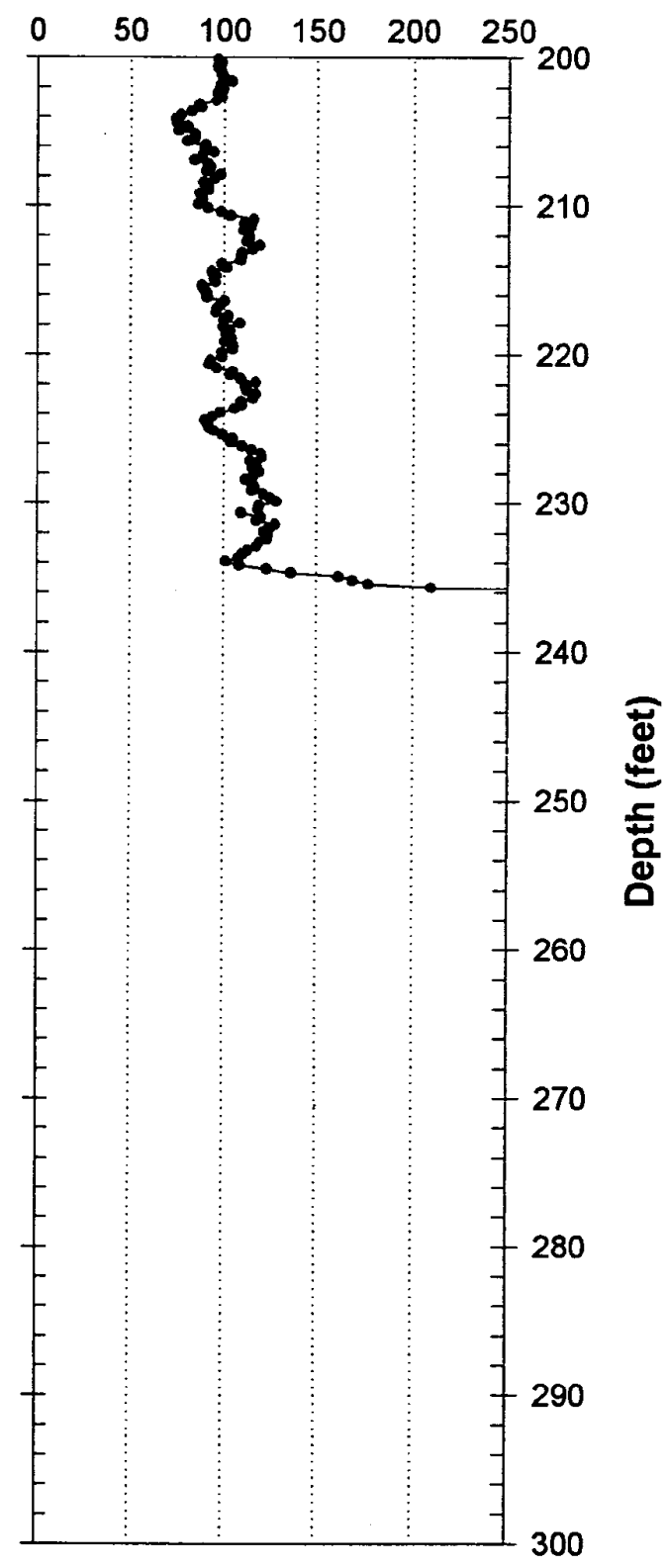

C. 17 


\section{RLS Spectral Gamma Ray Borehole Survey \\ Duratek Federal Services}

\section{Log Header}

Project: $\quad$ RCRA Drilling

Well: 299-W22-83

Log Type: HPGe Spectral Gamma Ray

Borehole Information

\begin{tabular}{|c|c|c|c|}
\hline Well \# C3126 & Water Depth & $236^{*}$ & Total Depth $274.2 \mathrm{ft}$ \\
\hline Elevation Reference $\underline{\mathrm{n} / \mathrm{a}}$ & Elevation & $\mathrm{n} / \mathrm{a}$ & \\
\hline Depth Reference Ground Surface & Casing Stickup & 1.75 & \\
\hline Casing Diameter 9.25 ID & Depth Interval & 0 to $273 \mathrm{ft}$ & Thickness \\
\hline
\end{tabular}

"Water depth determined from Moisture Log

Logging Information

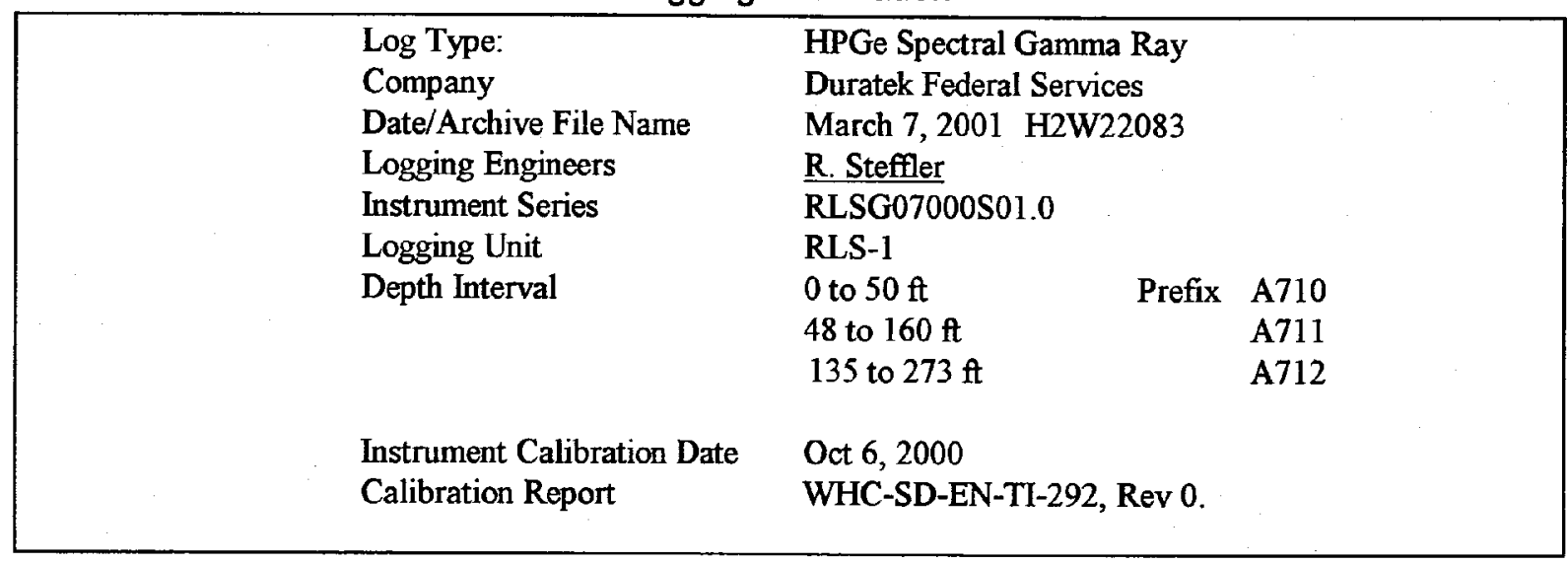

Analysis Information

$\begin{array}{ll}\text { Company } & \text { Three Rivers Scientific } \\ \text { Analyst } & \text { Russ Randall } \\ \text { Date } & \text { March 12, 2001 }\end{array}$

Notes No man-made contamination was detected. Many depth intervals have the natural uranium levels below detection threshold. The water level from 236 to 273 also reduces the gross gamma and raises detection thresholds. 


\title{
Spectral Gamma Ray Log Analysis \& Summary Waste Management Federal Services
}

\author{
Project: $\quad$ RCRA Drilling \\ Well: \\ 299-W22-83 \\ Log Type: HPGe Spectral Gamma Ray \\ Log Date: $\quad$ March 7, 2001
}

\section{General Notes:}

Total gamma is a response to geologic concentrations of natural radionuclides. A change in sensitivity of gross gamma to geologic concentrations of natural radionuclides occurs at the water level (236 feet).

Log data collected with a depth reference of ground surface.

System Performance Verify: The pre- and post-log verification passed performance standards; a $-0.03 \%$ change was observed in the gross, (based upon borehole survey data sheet). The FWHM of the $583 \mathrm{keV}$ photo peak was also within specifications for pre- and post-log verification.

Repeat Interval: Based on the repeat interval, the logging system performed as per specifications.

Environmental Corrections: All radionuclide concentrations have been corrected for casing attenuation (entire well). Water correction was applied to depths deeper than 236 feet. The information on the borehole survey data sheet indicates the water depth of 225 feet, but the moisture log response and the HPGe log response puts the water depth at 236 feet. No casing correction was applied to the total gamma due to Compton downscatter interference.

\section{Radionuclides:}

No man-made radionuclide contamination was detected. This observation was confirmed using a summing technique for the spectral data.

The natural uranium concentration is below detection threshold over many intervals. The changes in gross gamma from 130 to 150 and from 190 to 230 feet are reflected by changes in potassium, uranium, and thorium; which are indicative of geologic effects. Note that the use of the uranium signal is difficult due to the high statistical deviations and the high detection threshold. The drop in gross gamma at 236 feet is due to the water attenuation within the well. The rise in gross at 264 feet is reflected in a rise in the potassium and uranium over this same interval indicative of geologic changes just below the water level. 


\section{RLS Spectral Gamma Ray Borehole Survey Duratek Federal Services}

Project: RCRA Drilling

Borehole: 299-W22-83
Log Date: March 7, 2001

Naturally Occurring Radionuclides

Potassium Uranium Thorium Stacked Stacked Stacked $\mathrm{pCi} / \mathrm{g} \quad \mathrm{pCi} / \mathrm{g} \quad \mathrm{pCi} / \mathrm{g}$


Analysis by: Three Rivers Scientific 


\section{RLS Spectral Gamma Ray Borehole Survey Duratek Federal Services}

Project: RCRA Drilling

Borehole: 299-W22-83
Log Date: March 7, 2001

Naturally Occurring Radionuclides

Potassium Uranium Thorium Stacked Stacked Stacked

$\mathrm{pCi} / \mathrm{g} \quad \mathrm{pCi} / \mathrm{g} \quad \mathrm{pCi} / \mathrm{g}$

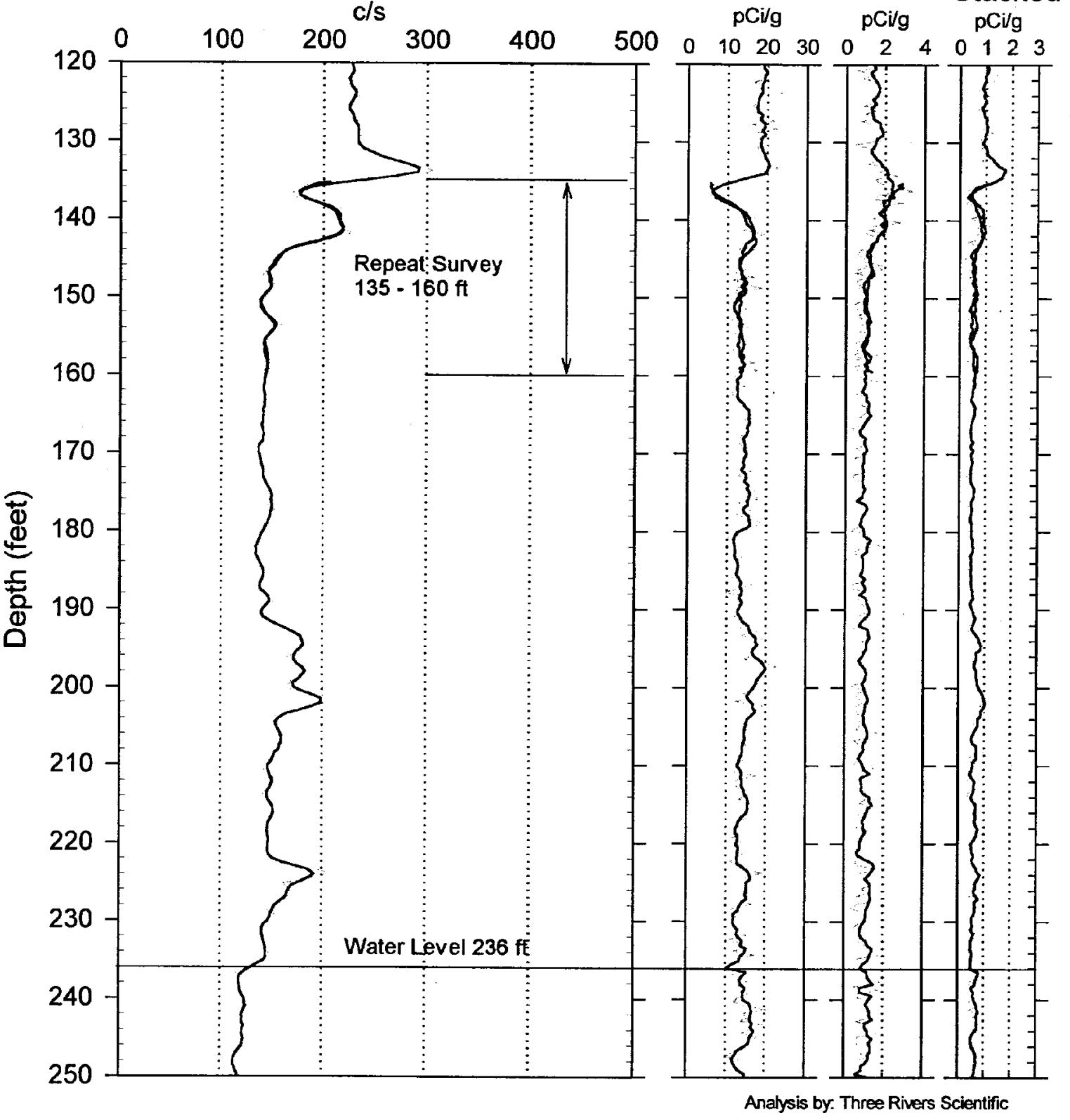




\section{RLS Spectral Gamma Ray Borehole Survey \\ Duratek Federal Services}

Project: RCRA Drilling

Borehole: 299-W22-83

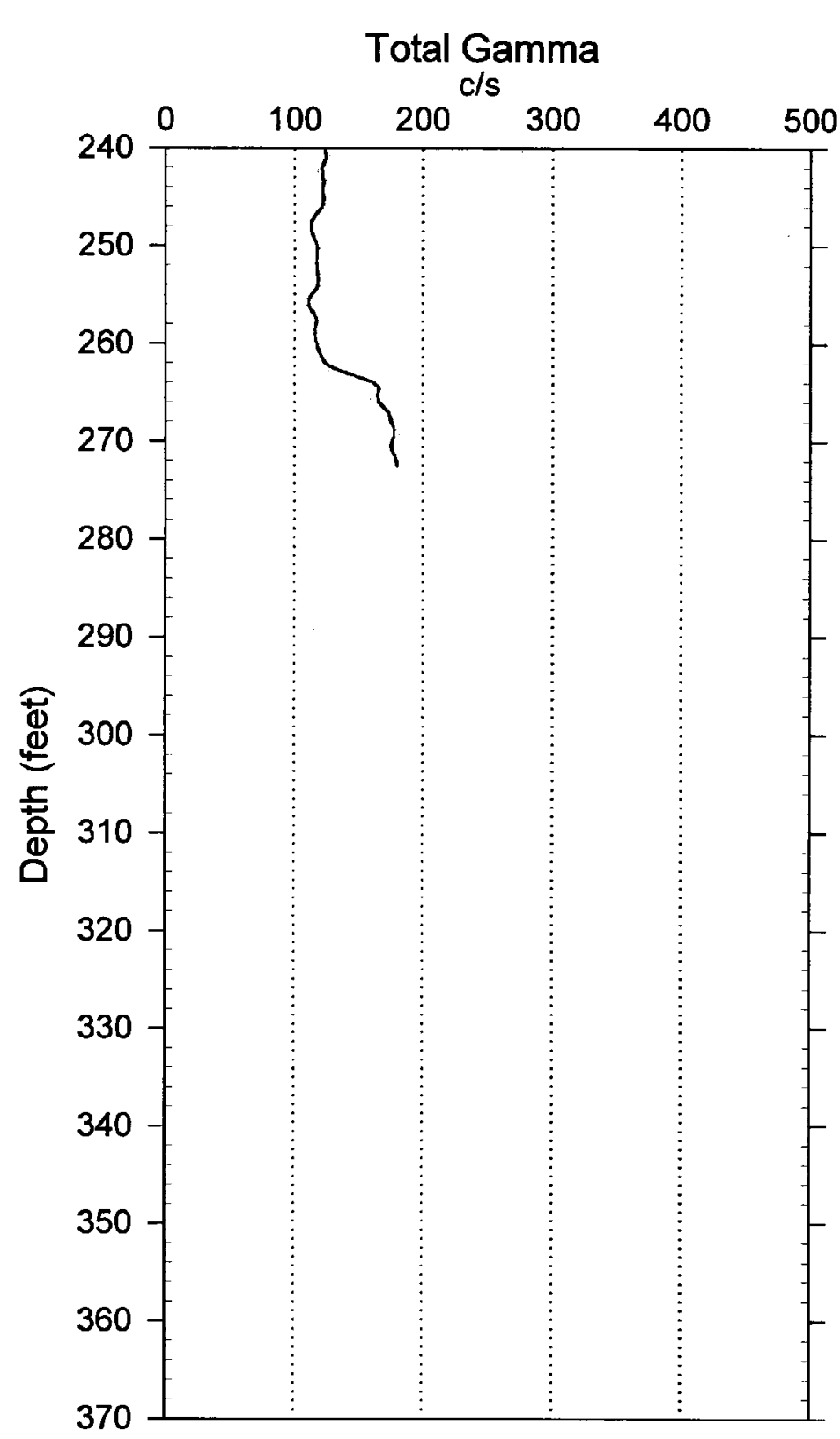

Log Date: March 7, 2001

Naturally Occurring Radionuclides

Potassium Uranium Thorium

Stacked Stacked Stacked

pCilg pCi/g pCi/g

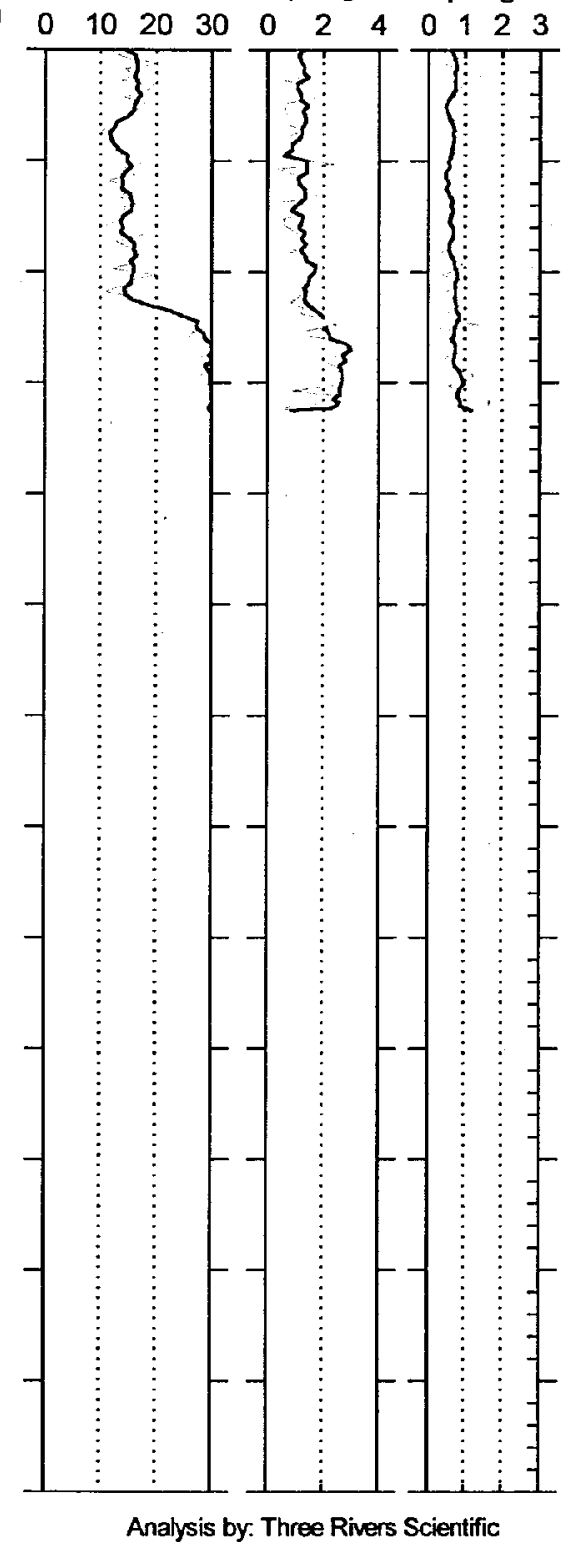




\section{Neutron-Neutron Moisture Borehole Survey}

Duratek Federal Services, Inc.

\section{Log Header}

Project: $\quad$ RCRA Drilling

Well: 299-W22-83

\section{Log Type: Moisture Gauge}

Borehole Information

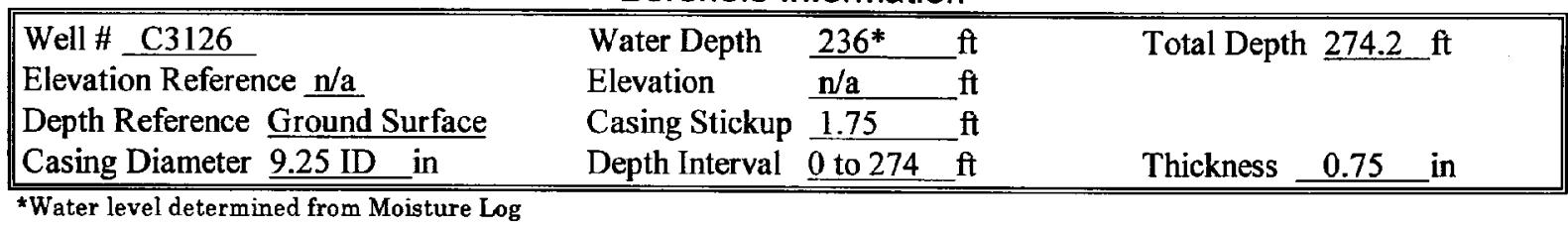

Logging Information

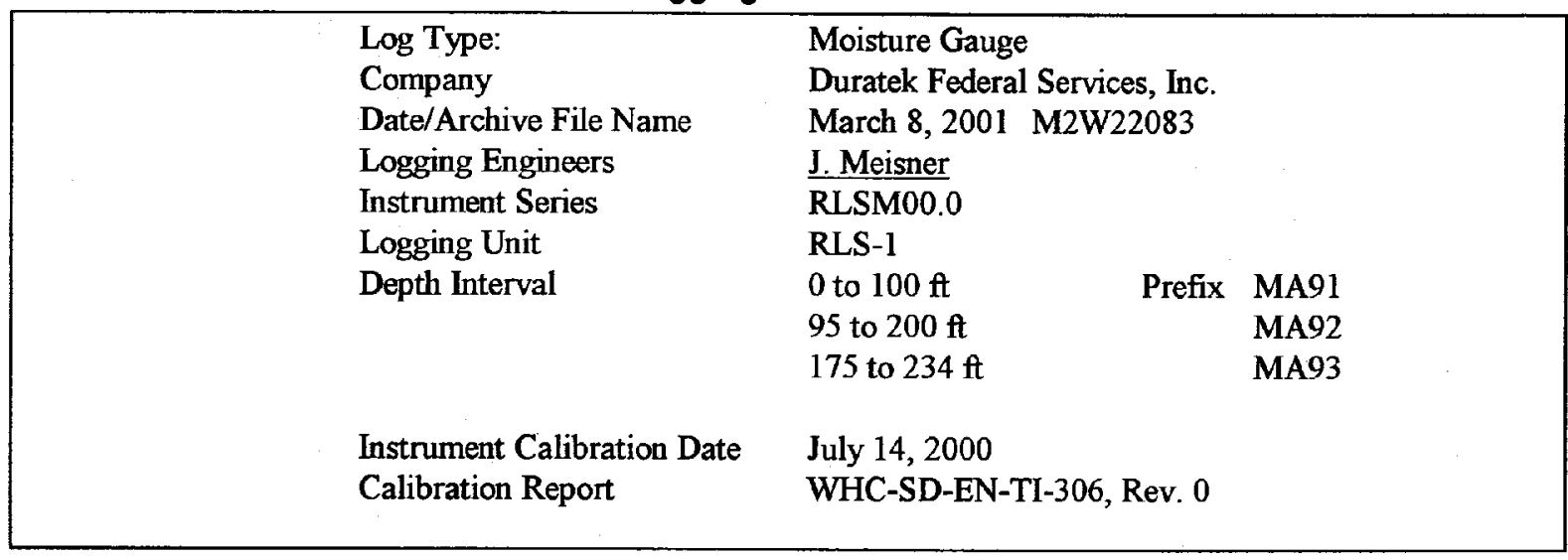

Analysis Information

$\begin{array}{ll}\text { Company } & \text { Three Rivers Scientific } \\ \text { Analyst } & \text { Russ Randall } \\ \text { Date } & \text { March 12, 2001 }\end{array}$

Notes Moisture values range from $2 \%$ to $18 \%$ for the depths logged. The onset of high moisture readings at 234 feet is due to the proximity of the water level in the borehole. No valid calibration is available for the 9.25 inch casing diameter from surface to 273 feet. The calibration for the 10.75 inch borehole diameter was extrapolated from standard diameter conditions, and casing correction applied to all depths logged. 


\section{RLS Neutron-Neutron Moisture}

\section{Duratek Federal Services, Inc.}

Project: RCRA Drilling

Borehole: 299-W22-83

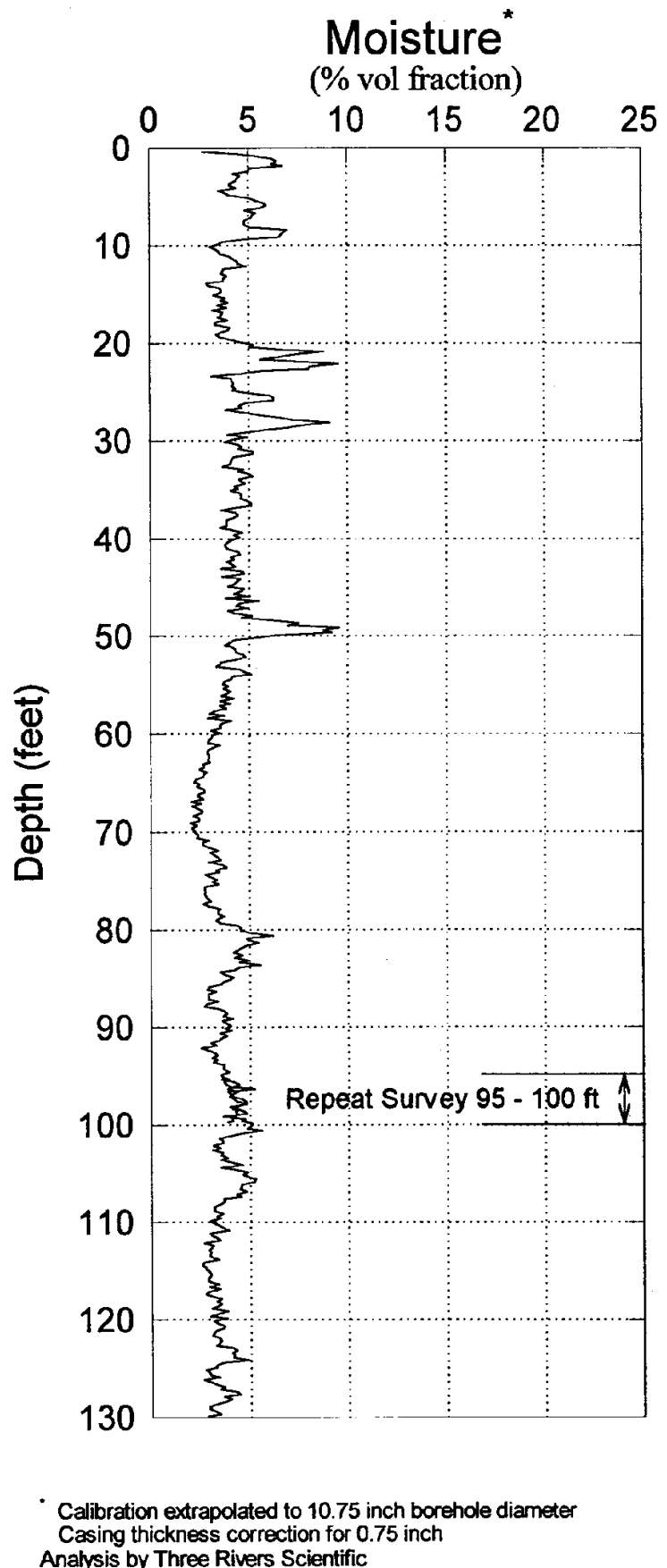

Log Date : March 8, 2001 Depth Datum : Ground Surface

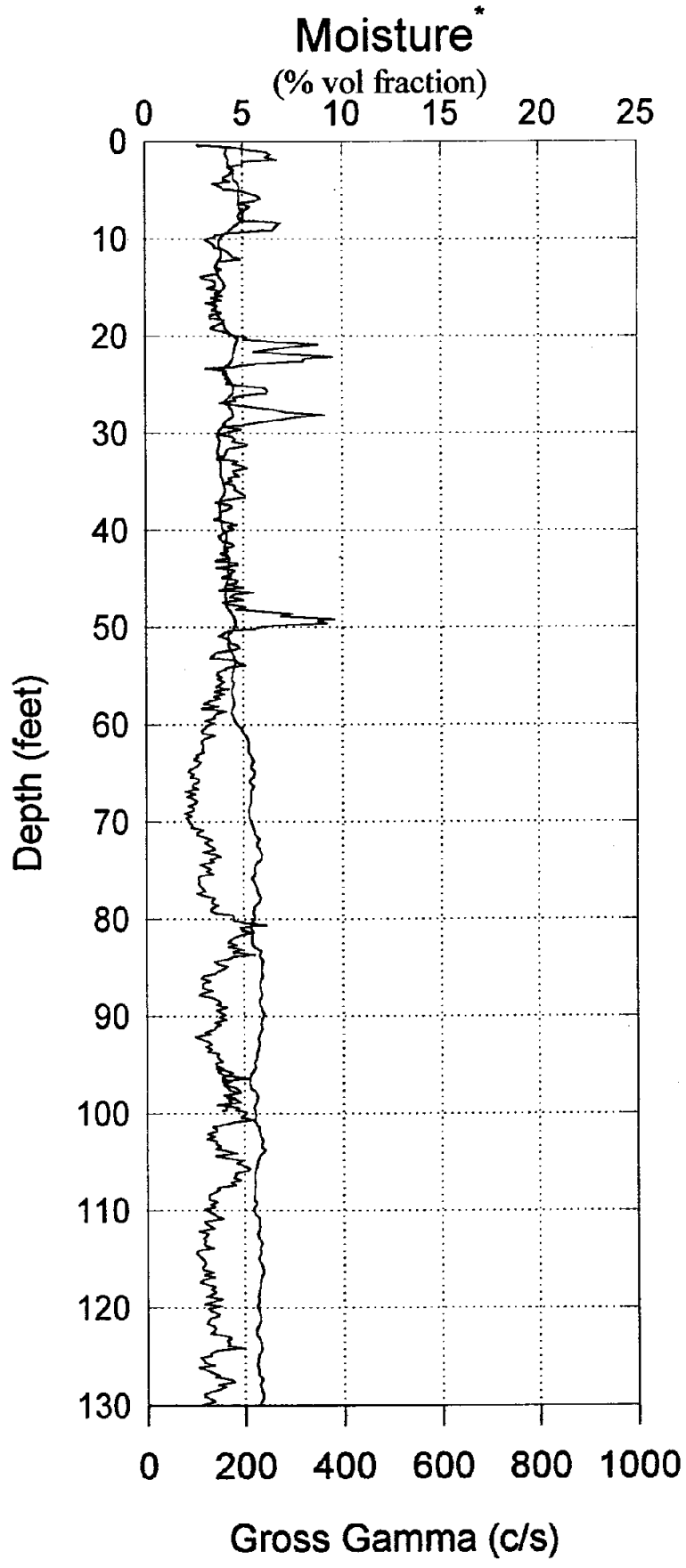




\section{RLS Neutron-Neutron Moisture}

\section{Duratek Federal Services, Inc.}

Project: RCRA Drilling

Borehole: 299-W22-83

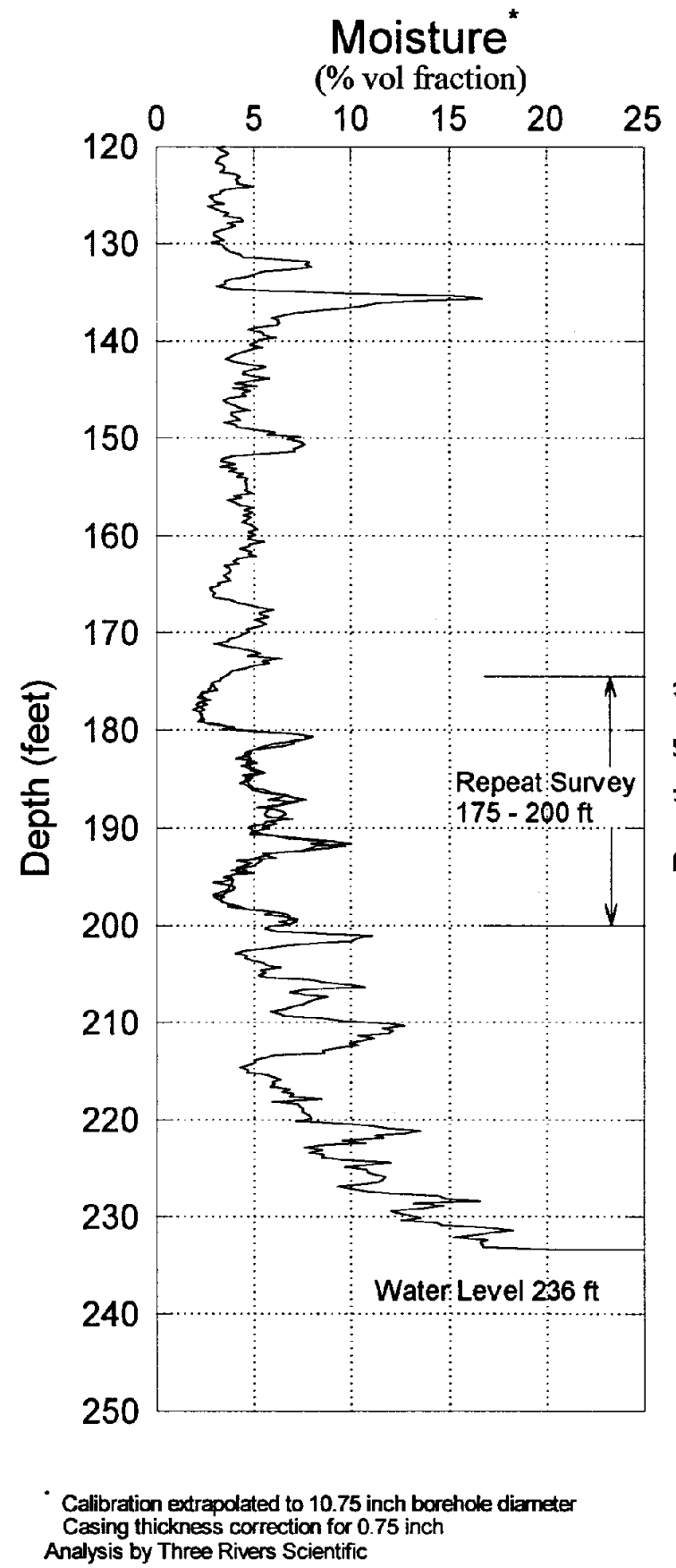

Log Date : March 8, 2001

Depth Datum : Ground Surface

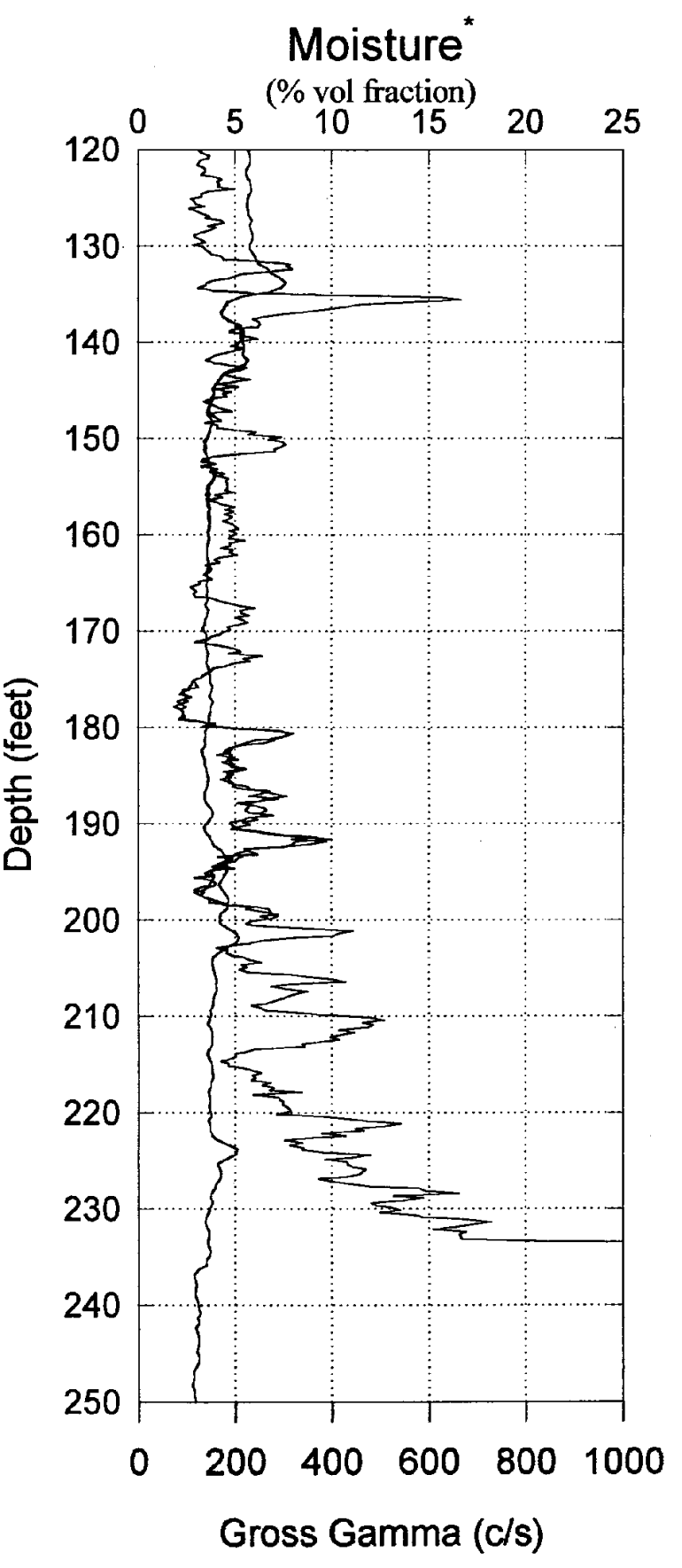




\title{
Moisture Log Analysis \& Summary
}

\author{
Duratek Federal Services, Inc.
}

Project: $\quad$ RCRA Drilling

Log Type: Moisture Gauge
Well ID:

Log Date:
299-W22-83

March 8, 2001

\section{General Notes:}

The largest borehole diameter for the calibration models is an 8.64 inch borehole diameter, with .32 inch casing thickness, and the borehole diameter in these $\log$ data is 10.75 inches. Therefore, an extrapolation was calculated for the applied calibration coefficients to match the conditions of the logged borehole. The method of extrapolation generated conservative estimates for the moisture values (possibly lower values than a valid calibration). The size differential of this borehole from the calibration standard is at the limits of rigorous extrapolation.

Log data collected with a depth reference of ground surface.

System Performance Verify: The pre- and post-log verification passed performance standards, $-7.4 \%$ change from start of $\log$ to end of $\log$, in the shield verify.

Repeat Interval: Based on the repeat intervals from 95 to 100 feet and 175 to 200 feet, the logging system performed according to specifications.

Environmental Corrections: The moisture levels have been corrected for casing thickness ( 0.75 inch) for all well depths logged. No formation density correction has been applied because density values are not available.

\section{Observations:}

The moisture levels show values ranging from $2 \%$ to $18 \%$ for all depth intervals logged. The average readings are somewhat lower than usual for Hanford vadose zone moisture levels, indicating that the calibration extrapolation is under correcting for the borehole diameter of this borehole. The abnormally high readings that begin at 234 feet are a response to the water level at 236 feet. Note that geologist's information puts the water depth at 225 feet. The date of the geologist's information is unknown, but the moisture log response and the HPGe $\log$ response put the water depth of 236 feet on March 8, 2001. 


\section{RLS Spectral Gamma Ray Borehole Survey \\ Waste Management Federal Services}

\section{Log Header}

Project: $\quad 2000$ RCRA Drilling

Well: 299-W23-21

\section{Log Type: HPGe Spectral Gamma Ray}

Borehole Information

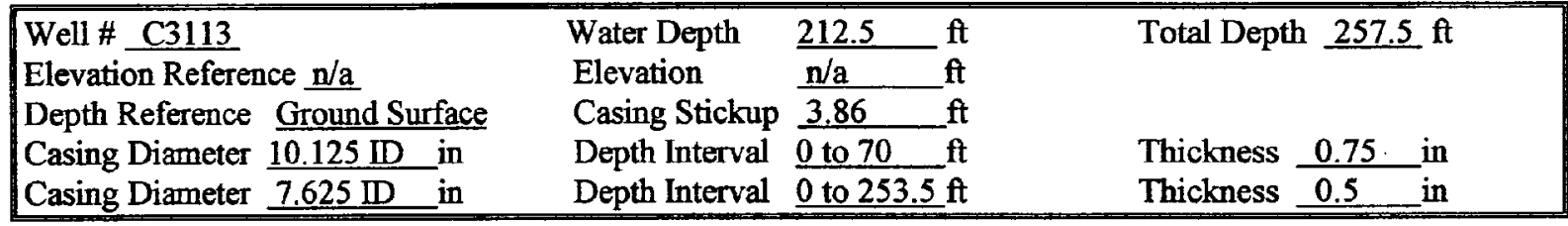

Logging Information

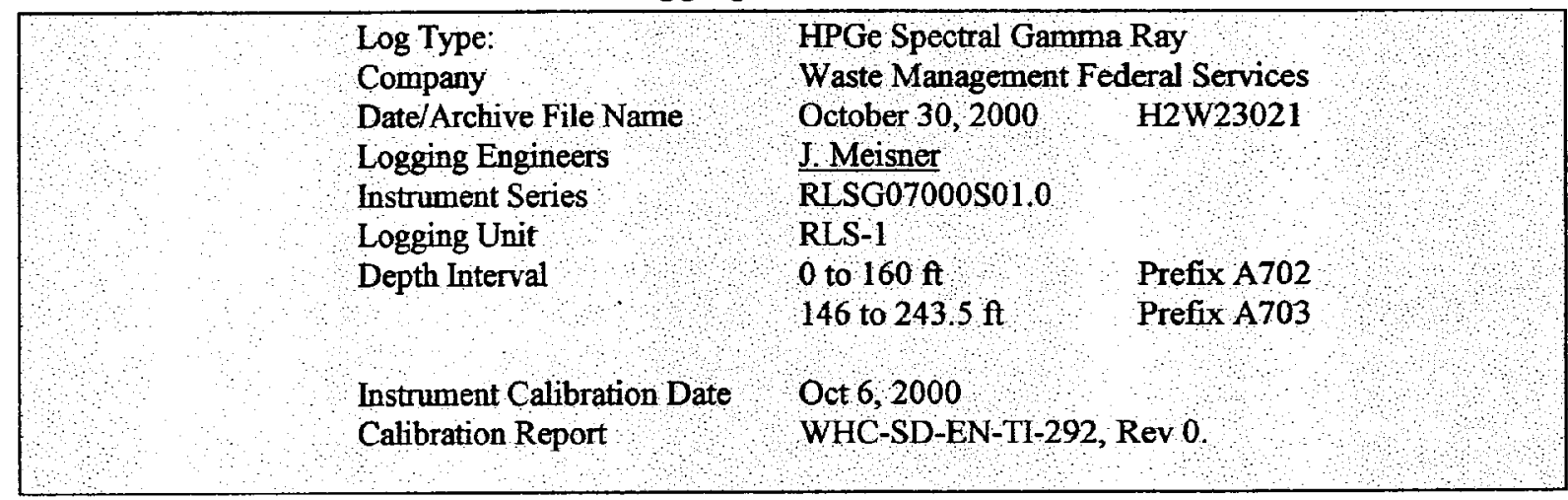

Analysis Information

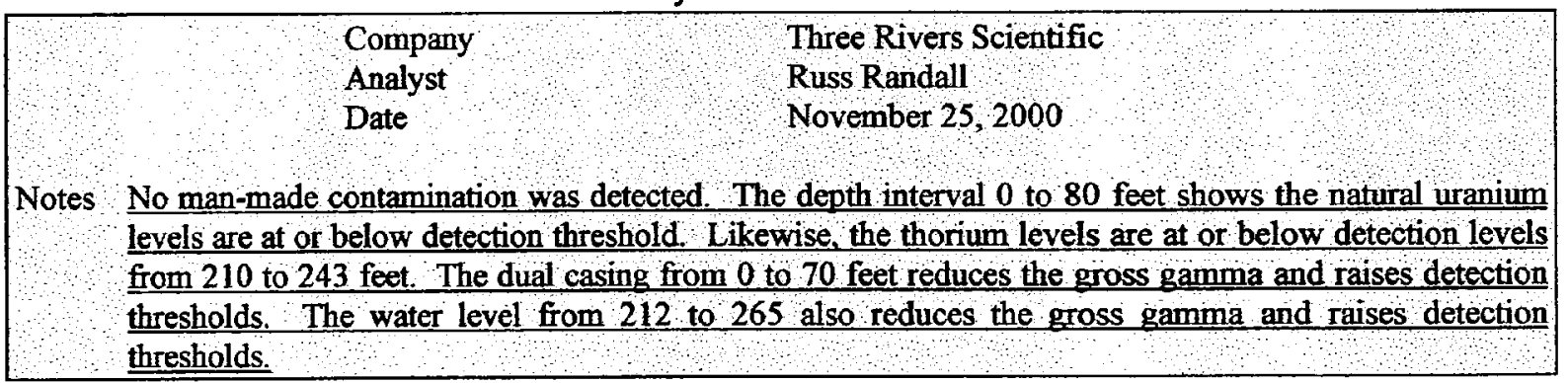




\section{RLS Spectral Gamma Ray Borehole Survey Waste Management Federal Services}

Project: 2000 RCRA Drilling

Borehole: 299-W23-21
Log Date: October 30 \& 31, 2000

Naturally Occurring Radionuclides



Potassium Uranium Thorium

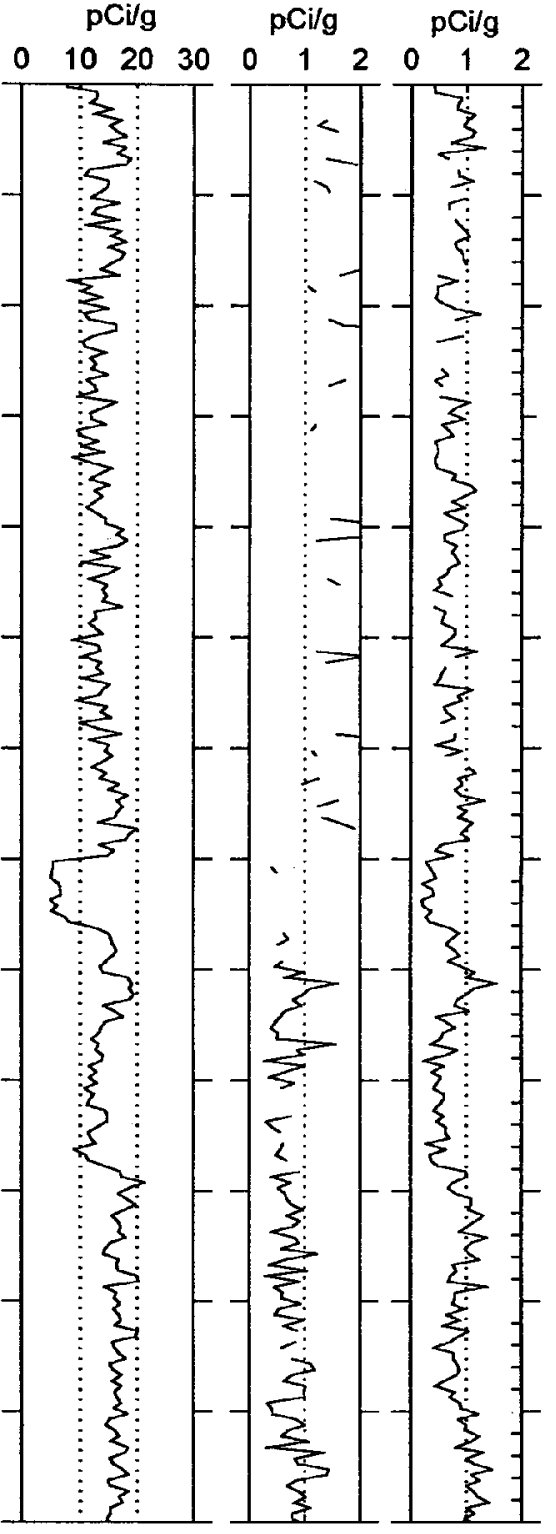

Analysis by: Three Rivers Scientific 


\section{RLS Spectral Gamma Ray Borehole Survey Waste Management Federal Services}

Project: 2000 RCRA Drilling

Borehole: 299-W23-21
Log Date: October $30 \& 31,2000$

Naturally Occurring Radionuclides




RLS Spectral Gamma Ray Borehole Survey

Waste Management Federal Services

Project: 2000 RCRA Drilling

Borehole: 299-W23-21
Log Date: October 30 \& 31, 2000

Naturally Occurring Radionuclides

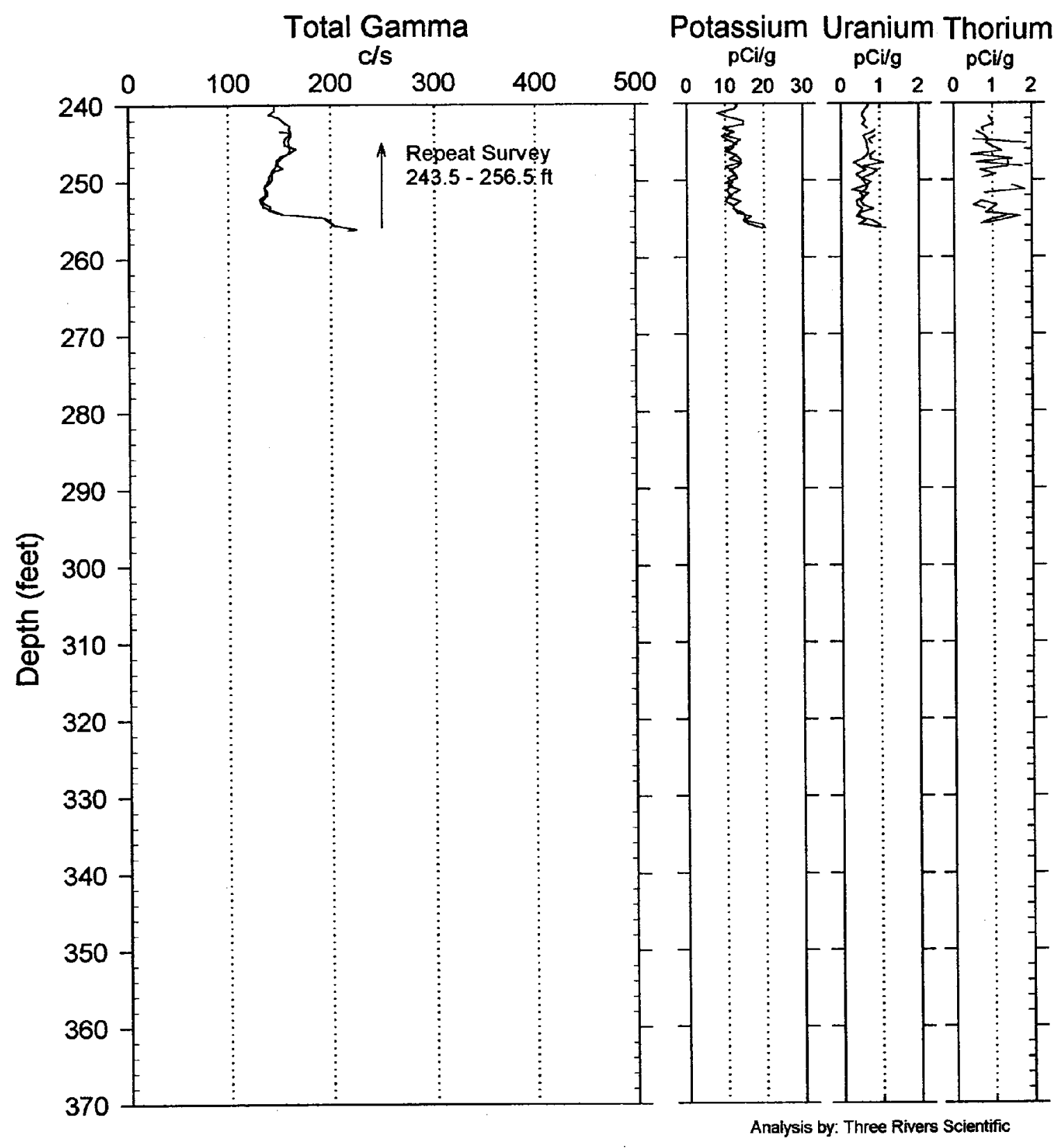




\section{Spectral Gamma Ray Log Analysis \& Summary Waste Management Federal Services}

Project: $\quad 2000$ RCRA Drilling

Log Type: HPGe Spectral Gamma Ray

Well:

299-W23-21

Log Date:October $30 \& 31,2000$

\section{General Notes:}

Total gamma is a response to geologic concentrations of natural radionuclides. Two changes in sensitivity of gross gamma to geologic concentrations of natural radionuclides occur at the dual casing change ( 70 feet) and the water level ( 212 feet).

Log data were collected with a depth reference of ground surface.

System Performance Verify: The pre- and post-log verification passed performance standards; a $-9.1 \%$ and $+0.3 \%$ change was observed in the gross (day 1 and day 2, respectively). The FWHM of the $583 \mathrm{keV}$ photo peak was also within specifications for pre- and post-log verification.

Repeat Interval: Based on the repeat interval, the logging system performed as per specifications.

Environmental Corrections: All radionuclide concentrations have been corrected for casing attenuation (entire well). Water correction was applied to depths deeper than 212 feet. No casing correction was applied to the total gamma due to Compton downscatter interference.

\section{Radionuclides:}

No man-made radionuclide contamination was detected.

The natural uranium concentration is below detection threshold from 0 to 80 feet, and the thorium is below detection threshold from 210 to 240 feet. Both of these intervals have additional gamma attenuation due to dual casing from 0 to 70 feet and the water annulus from 212 to 265 feet.

The changes in gross gamma from 75 to 110 feet are reflected by changes in potassium, uranium, and thorium; which is indicative of geologic effects. 


\section{Neutron-Neutron Moisture Borehole Survey \\ Waste Management Federal Services}

\section{Log Header}

Project: $\quad 2000$ RCRA Drilling

Well: 299-W23-21

\section{Log Type: $\quad$ Moisture Gauge}

Borehole Information

\begin{tabular}{|c|c|c|c|c|}
\hline Well \# C3113 & Water Depth & 212.5 & Total Dept & $257.5 \mathrm{ft}$ \\
\hline Elevation Reference $\underline{\mathbf{n} / \mathbf{a}}$ & Elevation & $\underline{n} / \mathbf{a}$ & & \\
\hline Depth Reference Ground Surface & Casing Stickup & 3.86 & & \\
\hline Casing Diameter $10.25 \mathrm{ID}$ in & Depth Interval & 0 to 70 & Thickness & 0.75 in \\
\hline Casing Diameter $7.625 \mathrm{ID}$ in & Depth Interval & 0 to $253.5 \mathrm{ft}$ & Thickness & 0.5 \\
\hline
\end{tabular}

Logging Information

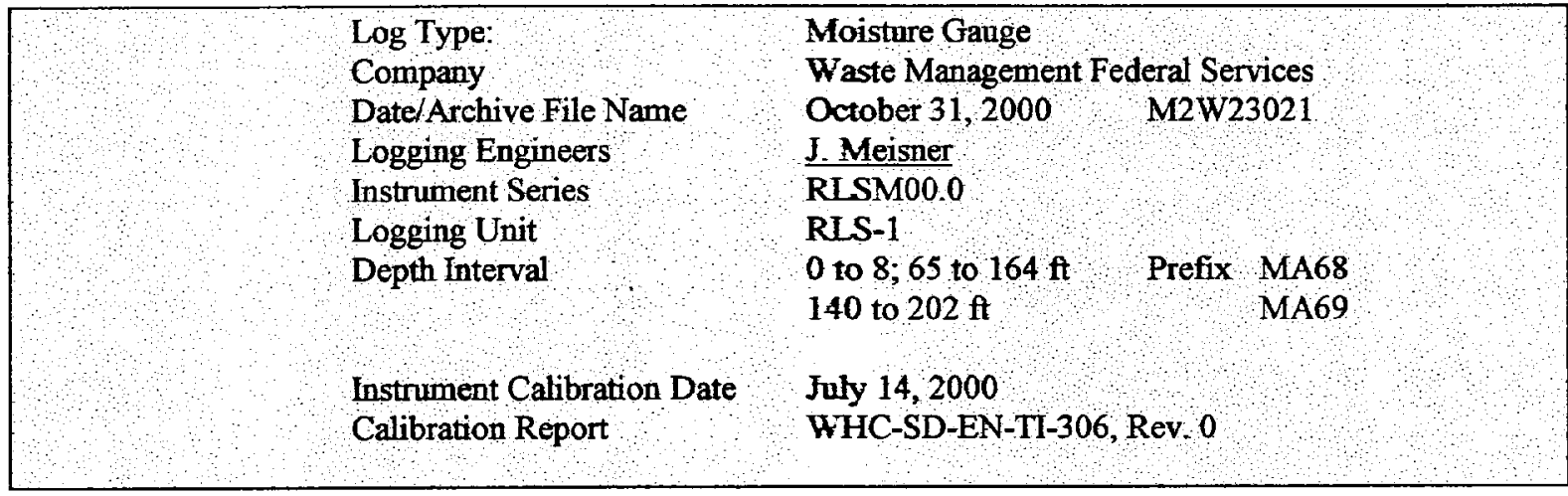

Analysis Information

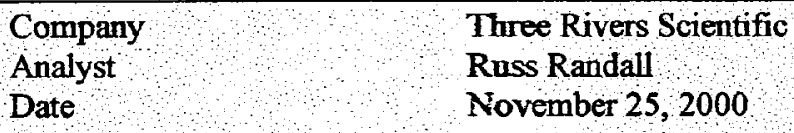

Notes Moisture values range from $2 \%$ to $32 \%$ for the depths logged. The onset of high readings at 212 feet is due to the proximity of the water level in the borehole. No valid calibration is available for the 10 inch casing diameter from surface to 70 feet thus the application of the 8 inch calibration is plotted as a blue line (with circle symbols) over 0 to 8.5 and 65 to 70 feet. 


\section{RLS Neutron-Neutron Moisture}

Waste Management Federal Services

Project: RCRA Drilling

Borehole: 299-W23-21
Log Date : October 31, 2000

Depth Datum: Top of Casing

Moisture Vol. \%

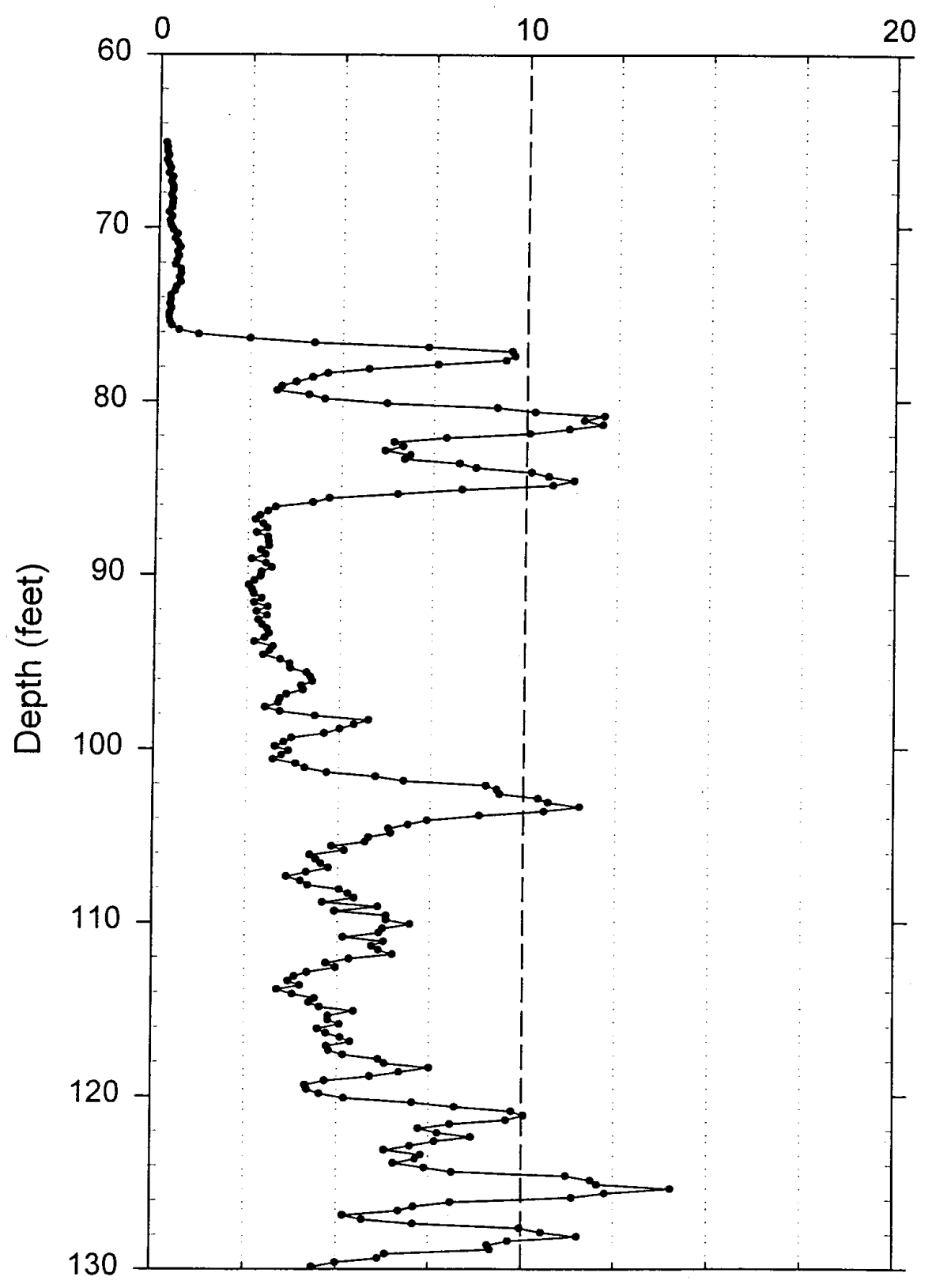

C.33 


\section{RLS Neutron-Neutron Moisture}

Waste Management Federal Services

Project: RCRA Drilling Log Date : October 31, 2000

Borehole: 299-W23-21 Depth Datum: Top of Casing

Moisture Vol. \%

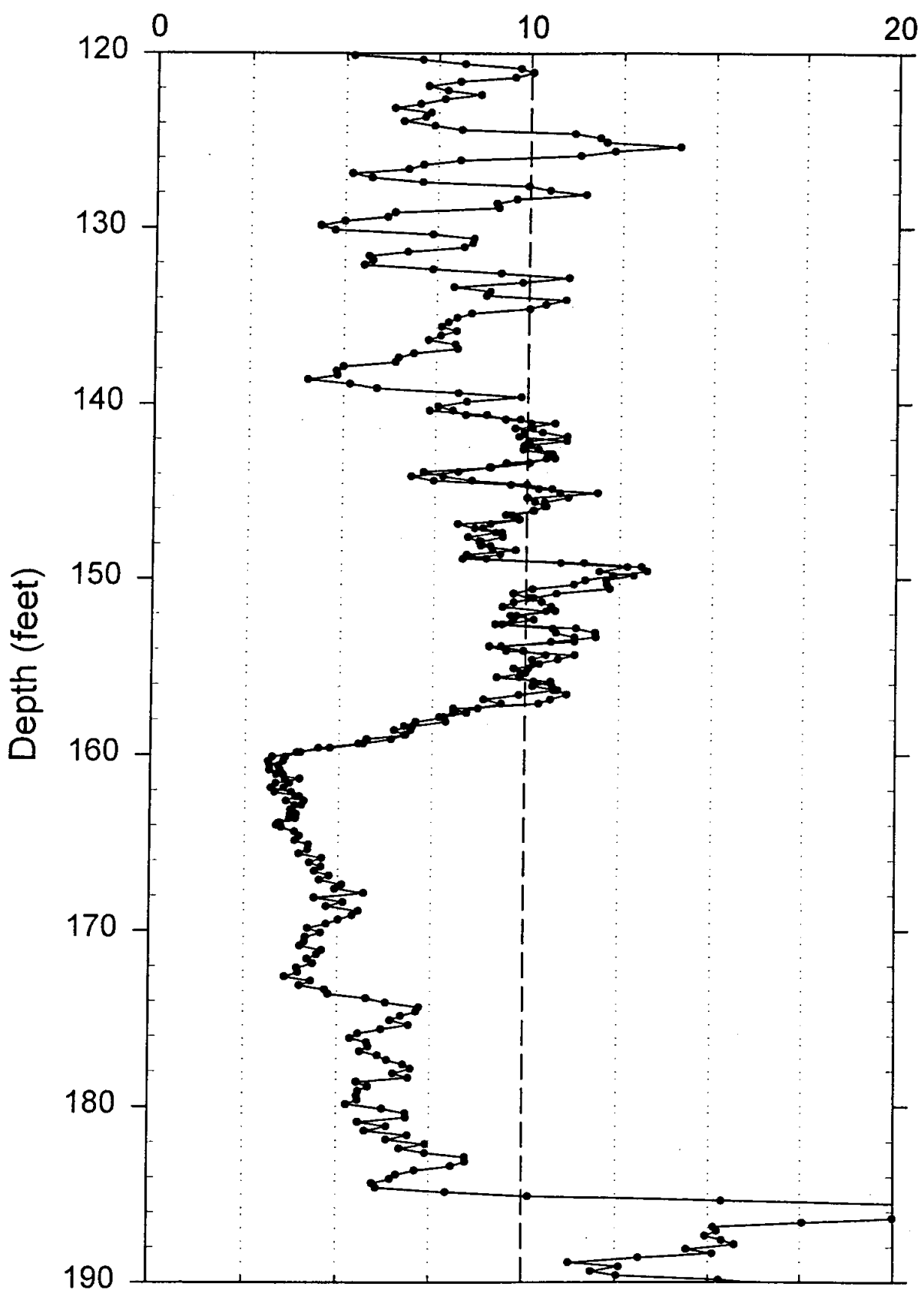

C.34 


\section{RLS Neutron-Neutron Moisture}

\section{Waste Management Federal Services}

Project: RCRA Drilling Borehole: 299-W23-21
Log Date : October 31, 2000

Depth Datum: Top of Casing

Moisture Vol. \%

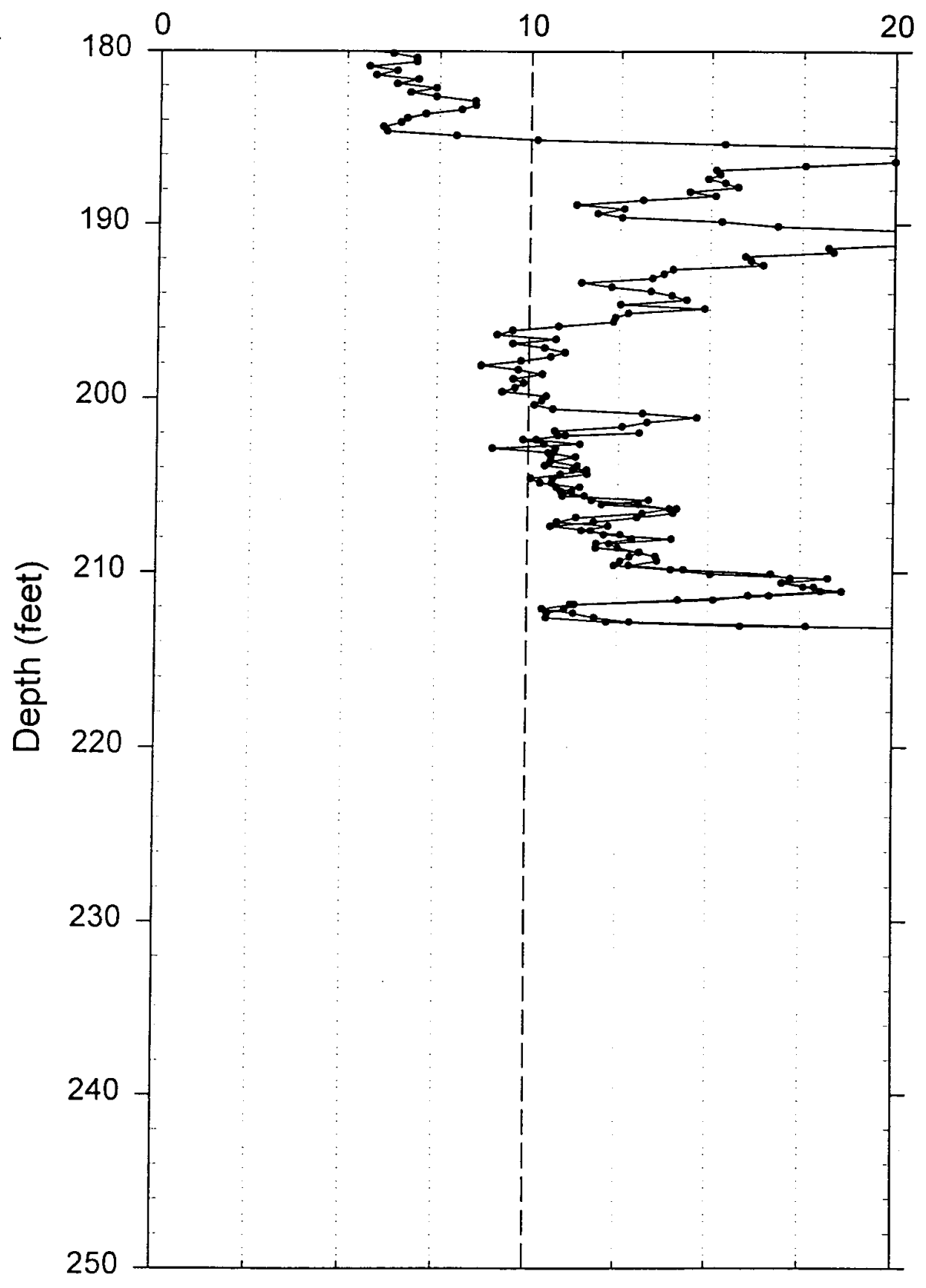

C.35 


\title{
Moisture Log Analysis \& Summary \\ Waste Management Federal Services
}

\author{
Project: $\quad 2000$ RCRA Drilling \\ Log Type: Moisture Gauge
}

Well ID:

299-W23-21

Log Date: October 31, 2000

\section{General Notes:}

The 8 inch calibration coefficients were used for all logged depths. The 8 inch calibration standard has an 8.64 inch borehole diameter, with .32 inch casing thickness, and the borehole diameter in these log data is 8.625 inches. The depth interval from 0 to 8.5 feet and from 65 to 70 feet has both the 8 inch and 10 inch casing. Thus the inappropriate use of the 8 inch calibration over these depths is plotted with a blue line and circle symbols. Note: no calibration exists for the 10 inch casing.

Log data were collected with a depth reference of ground surface.

System Performance Verify: The pre- and post-log verification passed performance standards, $-0.9 \%$ change from start of $\log$ to end of $\log$, in the shield verify.

Repeat Interval: Based on the repeat interval from 140 to 164 feet and 202 to 213 feet, the logging system performed according to specifications.

Environmental Corrections: The moisture levels have been corrected for casing thickness ( 0.5 inch) for all well depths logged. No formation density correction has been applied because density values are not available.

\section{Observations:}

The moisture levels show values ranging from $2 \%$ to $32 \%$ for the depth interval from 70 feet to 212 feet. The abnormally high readings that begin at 212 feet are a response to the water level at 212 feet.

Variable moisture structure shows from 75 to 212 feet. Over this depth interval, there is some correlation with the gross gamma signature, and sections with little correlation. Therefore, moisture content is sensitive to the geologic structure over this interval, while the changes in natural radionuclides is not as sensitive to the geologic structure.

The very low readings from 65 to 70 feet may be due to voids behind the casing 


\section{Distribution}

No. of

Copies

OFFSITE

Confederated Tribes of the Umatilla Indian Reservation

Environmental Planning/Rights Protection P.O. Box 638

Pendleton, OR 97801

ATTN: J. R. Wilkerson

L. Seelatsee

Wanapum Band

Grant County P.U.D.

30 "C" Street S.W.

P.O. Box 878

Ephrata, WA 98823

P. Sobotta

Nez Perce Tribe

Environmental Restoration/Waste

Management

P.O. Box 365

Lapwai, ID 83540-0365

Confederated Tribes and Bands of the Yakama Nation

Environmental Restoration/Waste

Management

2808 Main Street

Union Gap, WA 98903

ATTN: R. Jim
No. of

Copies

3 CH2M HILL Group
A. J. Knepp (2)
H0-22
D. A. Myers
$\mathrm{H} 0-22$

2 CH2M HILL Hanford, Inc.

J. V. Borghese H9-03

D. C. Weekes H9-02

3 Washington State Department of Ecology

B. Goswami B5-18

A. D. Huckaby B5-18

$\begin{array}{ll}\text { M. Brown B5-18 } & \end{array}$

U.S. Environmental Protection Agency

$\begin{array}{ll}\text { C. A. Faulk } & \text { B5-01 }\end{array}$

13 Pacific Northwest National Laboratory

V. G. Johnson (3) K6-96

D. G. Horton (3) K6-81

S. P. Luttrell K6-96

W. J. Martin K6-81

B. A. Williams K6-81

Hanford Technical Library (2) P8-55

DOE Public Reading Room (2) H2-53

\section{ONSITE}

\section{DOE-RL}

M. J. Furman (2)

R. M. Yasek

A5-13

H6-60 